Copyright 1983 Donald R. Walker 


\section{PENOLOGY FOR PROFIT: A HISTORY OF THE \\ TEXAS PRISON SYSTEM, 1867-1912}

by

DONALD R. WALKER, B.A., M.A.

A DISSERTATION

IN

HISTORY

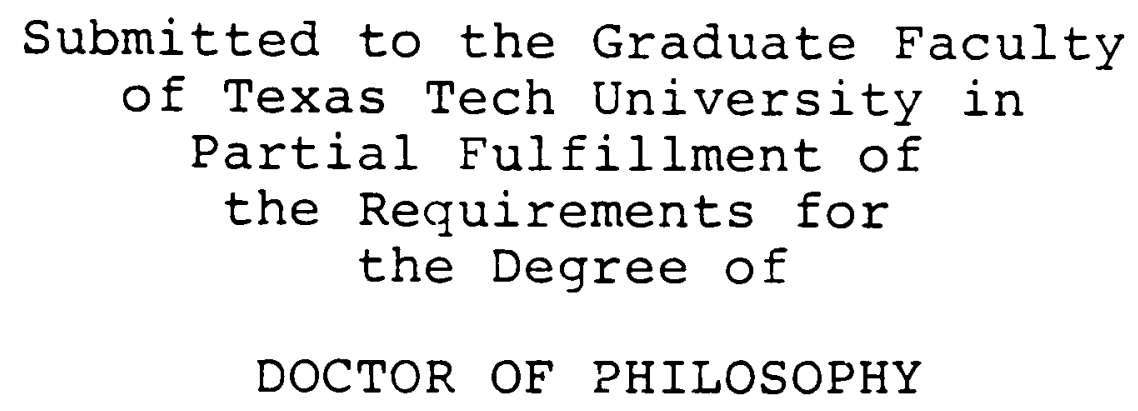

Approved 


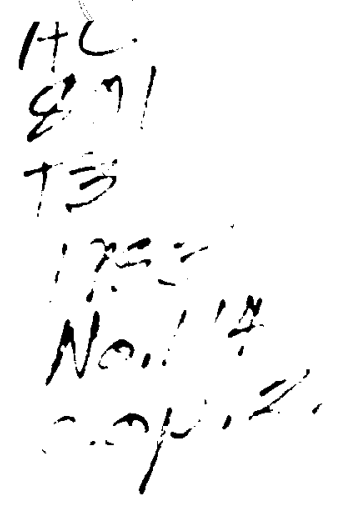

\section{ACKNOWLEDGMENTS}

In the course of preparing this dissertation, a number of debts have been incurred and must be acknowledged. To Professor James V. Reese goes my appreciation for having suggested the topic and guiding the initial research. Professor Alwyn Barr also made helpful recommendations with the research and supervised the writing of the manuscript. Both of these men gave considerable amounts of their time to assist me and I shall be in their debt always.

To Professors Otto Nelson, George Flynn, Key Ray Chong, and Marietta Morrissey I wish to express my thanks for reading the manuscript thoroughly and offering suggestions to improve the style of the writing and to clarify points of potential misunderstanding. Nirs. Joan Weldon labored diligently to decipher a barely legible handwritten draft and produced a professional typed copy. For her efforts, I thank her sincerely.

And finally, to my wife, Jonette, and my daughters, Jolie and Jennie, who persevered through this with me, I apologize for all the weekends and vacations they had to give up and promise to make amends. 
TABLE OF CONTENTS

ACKNOWLEDGMENTS . . . . . . . . . . . . . . . ii LIST OF TABLES. . . . . . . . . . . . . . . iv INTRODUCTION. . . . . . . . . . . . . . . . 1 Chapter

I. BACKGROUND TO LEASING: THE EARLY YEARS OF THE TEXAS PENITENTIARY. . . . . . . . . . 22

II. EARLY FAILURES, 1867-1878......... 32

III. THE SUCCESSFUL LEASE, 1878-1883. . . . . . . . 91 IV. THE STATE AS LESSOR, 1883-1912....... . 155 V. THE PRISONER'S LOT . . . . . . . . . . . 214 VI. THE POWERS THAT WERE: THE LEADERSHIP OF THE PRISON SYSTEM . . . . . . . . . . . . 272 VII. THE END OF LEASING . . . . . . . . . . . 311 VIII. THE TEXAS EXPERIENCE IN PERSPECTIVE. . . . . 362 BIBLIOGRAPHY. . . . . . . . . . . . . 374 


\section{LIST OF TABLES}

Table

Page

1. Prison Population, 1870-1912. . . . . . . 217

2. Prison Population by Race or Ethnic/

Nationality Group, 1880-1912. . . . . . . 219

3. Prison Population by Age, 1880-1912 . . . . 223

4. Classification of Prison Population

by Sex, 1880-1912............ 224

5. Educational Level of Prison Population, $1880-1912$. . . . . . . . . . . 225

6. Percentage of Prison Population Born in Texas, 1880-1912 . . . . . . . . . 227

7. Percentage of Prison Population Listed as Having no Trade or Occupation, $1880-1912$. . . . . . . . . . . . 228

8. Principal Crimes Committed, 1880-1912 . . . 231

9. Terms of Sentence, 1880-1912. . . . . . . . 233

10. Commitments and Recommitments, 1880-1912. . . 235

11. Number of Escapes and Deaths per Biennium, 1880-1912 . . . . . . . . . 237 


\section{INTRODUCTION}

A criminal justice system generally is considered to be composed of three separate, yet closely related, entities: the police, the courts, and the correctional facilities. Although each of the three acts within its own jurisdiction and from its own unique internal requirements, together they labor in unison to enforce and maintain those standards of behavior society has deemed necessary to guarantee stability. ${ }^{1}$ If a society is to endure and flourish, it must be willing to exercise its inherent right to protect itself from those of its members who violate the established laws. The criminal justice system serves as the medium through which such protection is accomplished.

Most people have occasion, at some time during their lives, to become somewhat familiar with the workings of the police and the courts. Relatively few, however, ever know much about the prison system. Most prisons are located in rather remote, rural areas and remain out

$1_{\text {The President's Commission on Law Enforcement }}$ and Administration of Justice, The Challenge of Crime in a Free Society (Washington, D.C.: United States Government Printing office, 1967), p. 7 . 
of the public consciousness until a riot or some other type of notoriety focuses attention on them. The general population, as a rule, understands little of how prisons are administered or the daily activities that make up prison life. In the words of the President's Commission on Law Enforcement and Administration of Justice, prisons are places that serve as "a rug under which disturbing problems and people can be swept." They incarcerate the "misfits and the failures, the unrespectable and the irresponsible." For this reason, the public "has been well content to keep them out of sight." 2

This dissertation will examine one part of the criminal justice system in Texas, the prisons. Specifically, it will look at the state penitentiaries as they functioned in the period between the end of the Civil War and the outbreak of World War I, a time during which the state routinely hired out the prison inmates to private individuals and corporations. In return for the labor of the prisoners, the private contractors agreed to pay the state either a specified amount of money or, in the case of share farms, a certain percentage of monies received from the sale of inmate-grown crops.

Previous studies of the state prison during the same period generally have not presented a complete

Ibid., pp. 11-12, 159. 
picture. Some have focused attention only on the political and institutional history of the system, providing little information on the prisoners themselves, the prison contractors, or the economics of leasing. Others have attempted to argue that state leaders in the postCivil War period conspired to use the lease system as a means of exerting social control over minority groups in the population. This study proposes to challenge the earlier works and demonstrate that the management of the state penal system during the late nineteenth and early twentieth centuries did not evolve as a result of any clearly-conceived and well-executed master plan. Instead it developed from the plodding and often haphazard efforts of state officials to provide for a growing inmate population at a time in which there was little money for state spending and limited public support for innovation in prison policy. ${ }^{3}$

3 William E. Blatner, "Some Aspects of the Convict Lease System in the Southern States" (M.A. thesis, University of Oklahoma, 1952); Herman Lee Crow, "A Political History of the Texas Penal System, 1829-1951" (Ph.D. dissertation, University of Texas, 1964); James Robertson Nowlin, "A Political History of the Texas Prison System, 1849-1957" (M.A. thesis, Trinity University, San Antonio, 1962); Thomas Michael Parrish, "This Species of Slave Labor: The Convict Lease System in Texas, 1871-1914" (M.A. thesis, Baylor University, 1976); James Robert Reynolds, "The Administration of the Texas Prison System" (M.A. thesis, University of Texas, 1925); Thomas E. Sullenberger, "An Interpretive History of the Texas Convict Lease System, 1871-1914" (M.A. thesis, the Institute of Contemporary Corrections and the Behavioral Sciences, Sam Houston State University, 1974). 
For the purposes of this study, convict labor will be defined as any arrangement in which private individuals or business entities profited from the labor of state prisoners. State laws also permitted county officials to set up work houses and road gangs to employ jail inmates. No attempt will be made to examine conditions and practices in the county jails, however, as their inclusion would result in a work of unwieldy size and scope. Thus this study will focus only on convict labor at the state level. 4

All major dimensions of the Texas convict labor system will be explored. In particular, the study will seek to determine why the state decided to hire out the prisoners, the nature of the political, legal, and economic framework under which the system flourished, how the system endured and was able to deflect criticism from its opponents, and the reasons it came to an end in the early twentieth century. Attention also will be directed toward identifying the individuals who hired the convicts, drawing a profile of the prisoners themselves, and describing conditions in the contract camps. The concluding chapter will place the major findings within the historiography of Progressivism and will compare the system as it

${ }^{4}$ United States Commissioner of Labor, Second Annual Report of the Commissioner of Labor, $18 \overline{86 . \text { Con- }}$ vict Labor (Washington: Government Printing Office, 1887), Pp. 592-594. 
existed in Texas with examples from the other southern states and with national developments in penology through the same period.

Before beginning the detailed look at early prison policies in Texas, it will be useful to trace the development of penitentiaries in other parts of the United States. The movement to establish institutions like prisons actually originated in Western Europe. It was in the United States, however, that the European ideas achieved their earliest fulfillment. The problems of early American prison administrators and the steps they took to devise practical, realistic solutions determined the function of the modern prison.

The agitation for prison reform in the United States originated in the general reform impulse associated with the early decades of the nineteenth century. The emerging nationalism and religious awakening of the period, coupled with the Enlightenment legacy of the American Revolution, produced an intellectual climate in which much of the traditional society came under close scrutiny. Established institutions, customs, and practices, many of which had arisen during the colonial period, received careful evaluation in light of the new nation's feelings regarding itself and its future. Those institutions found to be antiquated, inefficient, and ineffective became the targets of reformers bent on 
bringing a measure of rationality into the conduct of everyday life. 5

Those individuals who thought about crime and the problems it presented for early American society believed criminal conduct to be an anti-social aberration that could be corrected. Unlike their colonial predecessors, they did not see man as a naturally depraved being, easily corrupted by evil influences, whose good conduct could be guaranteed only by the fear of harsh, swift corporal punishment. Criminal behavior, in their view, arose out of the combined pressures of poverty and ignorance, coupled with the absence of any sense of civility or moral restraint. It naturally followed that to correct criminal behavior, society had to remove the offender from the surroundings and circumstances which had given birth to crime and provide the training and moral discipline which would make for good citizenship. The penitentiary became the institution, the instrument, society established to bring about reform of the criminal offender. ${ }^{6}$

Early American penitentiaries were designed to be places where convicted felons could be removed not only from the rest of society, but kept separate from the rest

5 David J. Rothman, The Discovery of the Asylum. Social Order and Disorder in the New Republic (Boston: Little, Brown and Company, 1971), pp. 57-62. ${ }^{6}$ Ibid., pp. 53-56, 62-72. 
of the prison population as well. Prison officials hoped such forced solitude would give the inmates ample time to repent of the wrongs they had committed against society and change their behavior for the better. Prisoners would be forced into the discipline of hard work and self-control and would be surrounded only by wholesome, uplifting influences that would inculcate in them the moral lessons they had not learned earlier in their lives. Upon completion of their terms of confinement, they could return to society prepared in every way to be productive, lawabiaing citizens. 7

The debate over how best to achieve the goals of penitentiary incarceration gave rise to two schools of thought, one centered in Pennsylvania, the other in New York. Both laid great stress on the moral component of reformation and sought, to a greater or lesser degree, to keep the inmates isolated from each other. Most importantly, both theories emphasized that inmates were to be kept busy at productive labor, the performance of which would instill in them habits of punctuality, sacrifice, and discipline. The major difference between the two systems involved the degree to which the prisoners were to be kept apart from each other, a question which ultimately determined the design of the prison and the

$$
{ }^{7} \text { Ibid., pp. } 82-85
$$


kind of work done by the inmates. 8

The Pennsylvania system of penitentiary management owed much to the Philadelphia Society for Alleviating the Miseries of Public Prisons. This Quaker group, founded in 1787, studied with considerable interest the works of leading European penal reformers, especially John Howard in England and Cesare Beccaria in Italy. The successful culmination of its study and effort came in 1829 with the completion of the Cherry Hill penitentiary in Philadelphia. 9

Under the Pennsylvania system, prison inmates were kept completely isolated from each other at all times. They could not make contact with other prisoners who might exert a negative influence on the process of reformation. Each inmate had his own private cell, with adjoining private exercise yard, and remained within these confines for the entire period of incarceration. Prisoners could speak only with prison officials or with ministers who provided Bibles and other religious literature upon request. 10

8 Ibid.

9 Blake McKelvey, American Prisons. A Study in American Social History prior to 1915 (Chicago, Illinois: The University of Chicago Press, 1936), pp. 5-11.

10 Ibid.; Rothman, Discovery of the Asylum, pp. 8485; Samuel Walker, Popular Justice. A History of American Criminal Justice (New York: Oxford University Press, 1980), pp. 66-67. 
The total isolation of each prisoner, the sine qua non of the Pennsylvania system, proved to be extraordinarily costly to attain. The rooms had to be relatively large since the inmates Iived and worked entirely within their cells. Efforts had to be made to conceal all pipes, and walls had to be a certain thickness to prevent any sound communication between prisoners. Such stringent design requirements meant that construction expenses for the Cherry Hill penitentiary totalled $\$ 750,000$, a sum which, in the words of one author, "staggered" the minds of contemporary penal experts. As the prison began to operate and implement its reform program, it became apparent that the inordinately high costs would continue. 11

Since prisoners could not leave their cells, except to exercise, they could do only limited kinds of work. Generally, small handcrafted items were all that could be produced. Production levels depended wholly on the varying speeds at which the individual prisoners could work. 12 Under such conditions, officials found it difficult, if not altogether impossible, to control either the uniform quality of the finished goods or the amount

${ }^{11}$ Mckelvey, American Prisons, p. 11; Rothman, Discovery of the Asylum, pp. 87-88.

12 Rothman, Discovery of the Asylum, pp. 83-88; Henry C. Mohler, "Convict Labor Policies," Journal of the American Institute of Criminal Law and Criminology 15 (May 1924-February 1925): 557 . 
produced in any given time period. Prison administrators, thus, could not count on prisoner-made goods as a dependable source of operating revenue.

While the Pennsylvania system had its fervent admirers, all of the expense factors taken together kept it from becoming popular with the rest of the nation. Most states found that they needed a system which would permit comparatively lower initial construction outlays and provide for a more dependable source of income when the prison began operation. The model for just such a facility was offered by the State of New York at its Auburn penitentiary. 13

The New York system, which began operation in 1823, also gave each inmate his own cell. Unlike Pennsylvania, however, New York prisoners were not kept in their cells at all times. During the day they labored in large workshops where, using steam-powered manufacturing equipment, they produced a variety of goods. The use of machinery afforded greater levels of production, more uniform quality of the finished product, and higher earnings for the prison--results guaranteed to please even the most cost-conscious legislators and prison administrators. 14

13 Walker, Popular Justice, pp. 67-68; Rothman, Discovery of the Asylum, pp. 87-88.

14 McKelvey, American Prisons, pp. 12-13; Walker, Popular Justice, pp. $66-67$; Harry E. Allen and Clifford 
While the prisoners were out of their cells and working together, they were forced to abide by strict rules of silence. No conversation among prisoners was permitted at any time, nor could any prisoner look another squarely in the face. Those guilty of violating any of the rules usually received whippings for their transgressions. ${ }^{15}$

Advocates of the Auburn system could argue that theirs was a realistic compromise solution to the problems of penal administration. Since the inmates used their cells only for sleeping, the individual units could be smaller in size. This translated into lower construction costs as it permitted more persons to be housed in a given amount of space. The labor and working arrangement brought in more money, while vigorous enforcement of the rules of silence enabled Auburn officials to argue that they too were preventing their charges from being further corrupted by their fellow prisoners. ${ }^{16}$

Despite the intensity of the debate over prison management, both schools of thought were in fundamental agreement as to the causes of criminal behavior and the

E. Simonsen, Corrections in America: An Introduction, 2nd ed. (Encino, California: Glencoe Publishing Co., Inc., 1978), pp. 39-40.

${ }^{15}$ Walker, Popular Justice, p. 67.

16 Mckelvey, American Prisons, p. 13; Rothman, Discovery of the Asylum, p. 88 . 
steps necessary to bring about reform. The fruits of idleness and wanton conduct that had brought the inmates to the prison were to be eradicated through strict regimentation and hard work. Old habits had to be broken and new ones learned. Harsh discipline became an essential tool to force the prisoners to adapt to the rigors of prison life. ${ }^{17}$

The universal conviction among leading prison reformers that hard work and discipline brought about the reform of criminal behavior almost inevitably led to the working of prison inmates for a profit. Administrators and legislators could hire out the labor of prisoners secure in the realization that they were helping to reform the individual. At the same time, the proceeds from the inmate labor eased the financial burdens of taxpayers who were dissatisfied at the thought of having to support prisoners in idleness. ${ }^{18}$ The desirability of working prisoners at some form of profitable employment so fixed itself in the minds of public officials that it became a hallmark of nineteenth century prison management in the United States.

Convict labor existed in four basic forms: the

17 Rothman, Discovery of the Asylum, p. 82.

${ }^{18}$ McKelvey, American Prisons, p. 12; Rothman, Discovery of the Asylum, pp. 103-104. 
contract, piece-price, public account, and lease systems. Each had the same basic goal, to keep the prisoners working, but all differed somewhat in structure. Some yielded greater profits; some required greater skill on the part of the convicts; and some gave greater authority to the private contractors. All shared the common objective of securing the highest level of production at the lowest possible labor cost. 19

The contract system, the type used at the Auburn penitentiary, became the most popular of the four types of prison labor. Under this arrangement, prison officials, at the instruction of their state legislatures, advertised for bids from private contractors who wished to work the prison inmates within the walls of the prison. Contracts usually were awarded to the highest responsible bidder. As a general rule, the contractors provided all necessary raw materials and furnished such skilled craftsmen and foremen as were needed to train and supervise the prisoners. The state, for its part, received a fixed price per man per day for the prison labor. Depending upon the terms of the contract, the contractor might also provide tools, machinery, and the power required to operate the equipment. The finished products manufactured by the

${ }^{19}$ U.S. Commissioner of Labor, Second Annual Report, 1886, pp. 371-382. 
inmates were taken by the contractor who would market them. 20

The popularity of the contract system derived chiefly from its profitability. Next to the lease system, contract labor brought in the largest return on state money. Once a contract was made, the state was assured a regular source of income. The contractor had to bear the burden of keeping the prisoners employed irrespective of any economic downturns or other reverses he might suffer. To default on a contract usually meant the automatic forfeiture of a rather substantial bond made at the time the contract was signed. 21

The state's responsibilities usually were considerably less onerous. The principal areas of state concern included maintenance of the prison plus the provision of food and medical care for the prisoners. 22 To guarantee that these costs were covered, the state could establish any amount it desired as the minimum contract bid.

20 Ibid., p. 372; Walker, Popular Justice, p. 71.

${ }^{21}$ U.S. Commissioner of Labor, Second Annual Report, 1886, p. 372 .

22 Ibid.; E. T. Hiller, "Labor Unionism and Convict Labor," Journal of Criminal Law, Criminology, and Police Science 5(1914-1915), pp. 862-863; Glen Albert Gildemeister, "Prison Labor and Convict Competition with Free Workers in Industrializing America, 1840-1890" (Ph.D. dissertation, Northern Illinois University, 1977), pp. 33-34. 
Although the contract system offered much to the individual states that adopted it, it also brought criticisms and problems. Free workers as well as prison reformers, as early as 1834, began to oppose the system and urge its immediate discontinuance. Workers resented the unfair competition which prison labor represented and argued that it depressed wages and demeaned the status of all workers. Prison reformers, while agreeing with worker complaints, further contended that basic steps leading toward the moral reformation of the prisoners were impossible as long as the state viewed its prison population as simply a source of revenue. Both groups, often working in concert, prevailed upon state legislatures to stop the exploitation of prisoners by private interests. 23

In an effort to appease and pacify the critics, some states modified the contract system. Under the piece-price arrangement, which developed in Northern prisons during the Civil War, the prisoners still worked within the prison for the benefit of private contractors and corporations, who supplied raw materials and paid a fixed price for each item manufactured. The work itself, however, was supervised exclusively by state employees,

23 U.S. Commissioner of Labor, Second Annual Report, pp. 373-379; McKelvey, American Prisons, p. 13. 
persons who, since they were public officials and not in the hire of the contractors, likely would be less concerned with profits and more solicitous of the well-being and morale of the prisoners. Neither the contractors themselves nor any of their employees were permitted to enter the prison compounds where the work was taking place. 24 The goods manufactured under the piece-price system were taken by the contractors and sold on the free market. The arrangement, thus, did nothing to alleviate the problem of competition with free labor. Prison officials, nonetheless, saw it as an improvement over the contract arrangement. By bringing the inmates under the exclusive control of the state, reform efforts such as opportunities for religious instruction and basis education could proceed free of any disruptive influences from representatives of the private contractors. 25

Under both the contract and piece-price systems, the individual states attempted to retain at least a modicum of control over the inmates. Although the labor was given over to the contractors, the states continued to provide housing, food, clothing, and medical care.

24 Ibid., p. 379; Harry Elmer Barnes, The story of Punishment. A Record of Man's Inhumanity to Man, 2nd ed. (Montclair, New Jersey: Patterson Smith, 1972), p. 219 .

25 U.S. Commissioner of Labor, Second Annual Report, 1886, p. 379 . 
Such arrangements permitted state officials to discharge the responsibilities of stewardship assigned them by the state penal code. At the same time, money received from the outside employers helped defray at least part of the prison operating expenses, thereby reducing the amount that would have to come from legislative appropriation. Those states that were interested solely in the amounts of money they could make from prison labor generally chose the lease system, the most profitable form of penitentiary management. Although leasing reached the peak of its popularity in the post-Civil war South, the system had come into existence many years earlier in other parts of the nation. As early as 1798, the Massachusetts legislature authorized prison officials to hire out state prisoners to private parties. California adopted leasing for a short time in the late $1840 \mathrm{~s}$ and several Northern prisons did the same during the early 1860 s when wartime manufacturers ran short of labor. Not until the reconstruction South embraced the system, however, did it become entrenched for a long period of time. 26

The terms of the lease contract usually called

${ }^{26}$ Hilda Jane Zimmerman, "Penal Systems and Penal Reforms in the South Since the Civil War" (Ph.D. dissertation, University of North Carolina, Chapel Hill, 1947), pp. 22-24; Barnes, Story of Punishment, p. 219. 
for the state to yield control of its prisons, along with all equipment, buildings, property, and inmates, to the highest competitive bidder. The lessee then could employ the prisoners in any way he chose, even subcontract them to other individuals, subject only to very minimal state regulation and control. In return for the lease of the prison, the lessee paid the state a specified amount of money at regular intervals, usually annually. 27

In adopting the lease system, a state abdicated virtually all responsibility for the welfare of its prisoners. As a result, the typical lease camp was inhabited by people who were poorly-fed, poorly-clothed, poorlyhoused, denied proper medical care, and worked beyond all reasonable limits. Unless state officials were particularly diligent in seeing that their prisoners were cared for properly, the lessees, most of whom had personal profit uppermost in their minds, did as they chose. Most states did not exercise such diligence, so the lease system was characterized by unconscionable levels of brutality, cruelty, and neglect. 28

27 U.S. Commissioner of Labor, Second Annual Report, 1886, pp. 381-382; Robert T. Devlin, "Prison Labor," Overland Monthly 7 (May 1886): 505. 28 McKelvey, American Prisons, pp. 180-185;

George W. Cable, The Silent South Together with the Freedman's Case in Equity and the Convict Lease System (New York: Charles Scribner's Sons, 1885), p. 122. 
The ideal form of prison labor--the one endorsed to a greater or lesser degree by both reformers and free workers--was the public account, or public use, system, which came into existence in the 1870 s as a result of pressure from organized workers. Under this arrangement, prisoners worked within the prison walls completely under state control manufacturing goods for use by state institutions. Any articles produced in excess of state needs were sold on the free market with the profits, if any, going into the public coffers. Under the public account system, private individuals did not gain from the labor of the prisoners. 29

Although the public account system forestalled the exploitation of the prison inmates by private interests, it was not without other problems. For the system to function as planned, it required leadership from prison officials who were competent both as correctional officers as well as practical businessmen--individuals who could see to the proper care and discipline of the inmates as well as plan and implement business policies that would be successful in a competitive and unpredictable marketplace. Judging from the relatively small number of states that adopted the public account system,

${ }^{29}$ U.S. Commissioner of Labor, Second Annual Report, 1886, pp. 379-381. 
one may conclude that individuals possessing both qualities were not easy to find. 30

Organized labor responded to the public account system in a somewhat mixed manner. American workingmen actually preferred the system over the other forms of prison labor. But they resented the states selling surplus goods on the free market, particularly at the low prices at which the goods could be sold. Since the states had paid nothing for the labor to manufacture the products, they only had to recoup the cost of the raw materials to avoid a financial loss. The goods produced by free workers simply could not compete successfully with the prison-made products. $^{31}$

Labor argued for reforms that would make the system less destructive of the free marketplace. For one thing, it wanted prison industries to become as diversified as possible so as to diminish the amount of injurious competition that would fall on any one sector of the free work force. The prisoners would produce small amounts of many products rather than large amounts of a single product. The resulting competition thus would be minimal over all industries rather than destructive to any one.

${ }^{30}$ Ibid.

31 Ibid.; "Sanity in Solving Prison Labor Problem," American Federationist 2 (September 1904): 774-777. 
Free workers also wanted the prisoners to be paid for their labor. The money, they contended, could be used to help support the prisoners' families who were left without a source of income. ${ }^{32}$ Labor also must have known that by paying the prisoners a wage, the states would have had to raise the prices of the prisoner-made products, a situation that could only have benefitted free workers.

The debate over prison labor, including assessments of the relative advantages and disadvantages of each system, consumed a great deal of the time and effort of early penitentiary administrators. The prison population during the nineteenth century grew constantly, forcing society to decide what it wanted its prisons to be and how it wanted them to function. To a large degree, the effort by Texas lawmakers to establish and maintain a prison system involved considerations similar to those being discussed in other parts of the nation. The policies and programs adopted by Texas officials to deal with an increasing prison population forms the subject of this paper.

32 E. Stagg whitin, "Trade Unions and Prison Labor," Case and Comment 19 (September 1912): 243-244. 
CHAPTER I

\section{BACKGROUND TO LEASING: THE EARLY YEARS \\ OF THE TEXAS PENITENTIARY}

The idea that prisoners should work to defray at least part of the cost of their incarceration has been characteristic of penology in Texas since the advent of organized government to the state. Beginning when Texas was governed by Mexico and continuing through statehood, legislators and other public officials continually have sought to keep the prisoners busy performing some type of useful and financially-remunerative labor. Although the various plans and programs of prison labor have not always obtained the desired results, state officials have, nonetheless, maintained their belief that supervised work forms a vital part of prison rehabilitation efforts. As early as 1829, public officials governing the Mexican state of Coahuila and Texas directed their attention toward establishing an organized state penal system to ease the burden on local jails. In that year, the Congress of the state empowered the governor to enter into contract with private individuals to build two prisons, one in the department of Bexar, the other in 
the district of Parras. Under the contract terms, the contractors were permitted to use inmate labor to construct the prisons. Upon completion, the contractors would be entitled to receive all profits from the inmates' labor for two years. They would then share the profits equally with the state for an additional three years and at the end of the total of five years, the prisons would become the exclusive property of the state. ${ }^{1}$

The 1829 law also contained provisions designed to guarantee that individuals sentenced to the new prisons would emerge from their confinement better equipped to become productive members of society. The contractors were required to teach the inmates a useful trade and to provide them, upon their release, with $\$ 30$ and the tools to continue the trade in free society. ${ }^{2}$

$\Gamma$ Although the two prisons were never built, the provisions of the 1829 law reflected the latest in penological theory. Like their counterparts in the United States, especially those in New York, the Mexican officials believed prisons could be profitable for the state. At the same time, inmates forced to work during their time of incarceration would be prepared for useful

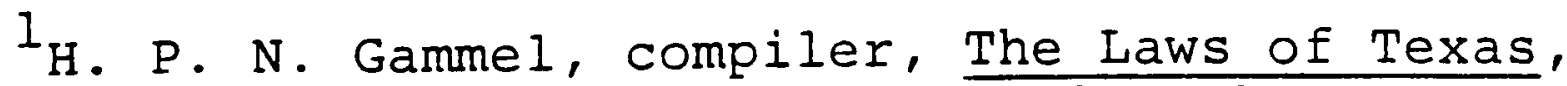
1822-1897, 10 vols. (Austin: The Gammel Book Company, 1898), 1: $130-131$.

2 Ibid. 
citizenship upon their release. ${ }^{3}$

With the demise of the 1829 law, punishment of convicted lawbreakers again became a function of local officials. This situation continued throughout the Republic period even though there were several unsuccessful attempts to get the Congress of the Republic to establish a national prison. 4 It was not until the early years of statehood, following the end of the war with liexico, that the Texas legislature passed formal legislation enabling the construction of a state prison. ${ }^{5}$

The bill which made the Texas penitentiary a reality received legislative approval on March 13, $1848 .^{6}$ To a large degree, its passage reflected the growing realization that in an organized society, the state must assume responsibility for and take the lead in penal matters. 7 The various provisions in the law seemed to anticipate any eventualities that might arise, and are

${ }^{3}$ Ibid.

${ }^{4}$ Crow, "Political History of the Texas Penal system," pp. 21-31; Nowlin, "Political History of the Texas Prison System," pp. 3-7.

${ }^{5}$ Crow, "Political History of the Texas Penal System," pp. 21-27; Gammel, Laws of Texas, 1: 79-84; Nowlin, "Political History of the Texas Prison System," pp. $2-7$.

${ }^{6}$ Gammel, Laws of Texas, 1: 79-84.

${ }^{7}$ Nowlin, "Political History of the Texas Prison System," pp. 7-10. 
worth examining in some detail as a basis for comparisons with modifications and amendments that had to be made later as new and unforeseen problems arose.

The language of the penitentiary act indicated quite clearly the intentions of the legislature with regard to both the construction of the facility as well as the later management of the inmates. The governor was required to appoint immediately three persons to locate a site for the new prison. The spot chosen should be no larger than 100 acres and should not cost more than five dollars per acre. It should be in a healthy climate and near a navigable body of water so as to permit, "the importation of machinery, tools, [and] materials to be - . manufactured, and for the transportation of articles made. . by the convicts to a market. . ." 8

Once the state located and purchased a suitable site, the governor, acting with the consent of the senate, was to appoint an individual to serve as superintendent and be responsible for the daily operation of the facility. This position would carry with it an annual salary of one thousand dollars. ${ }^{9}$ The law made no statement as to any qualifications or prior experience required of the individual appointed, an omission that would open the way for

\footnotetext{
${ }^{8}$ Gammel, Laws of Texas, 1: 79.

${ }^{9}$ Ibid., p. 84 .
} 
the position to become a plum of patronage.

The first duty of the superintendent was to procure a plan for the new prison and submit it to the governor for approval. Once this was done, he then could hire such workers and craftsmen as were necessary to begin construction. As soon as "part of the main buildings" were completed, the superintendent could discharge the paid workers and complete the work with prison inmates. 10 The legislators spoke also about the type of facility they desired. The buildings were to be constructed of "substantial materials" and surrounded by a "secure wall" that would enclose an area large enough to permit the construction of workshops. The prisoners would be kept busy at whatever type of labor the state deemed to be, "most profitable and useful. . . ." The prison was to be managed according to the precepts of the Auburn Plan in that although the prisoners would work together during the day, they were to return to their solitary cells at night. ${ }^{11}$

In addition to the superintendent, the governor also was required to appoint three persons, again subject to senate confirmation, to serve as directors of the prison. These men would be responsible for

$$
\begin{aligned}
& 10_{\text {Ibid. , p. } 80 .} \\
& { }^{11_{\text {Ibid. }}}
\end{aligned}
$$


establishing prison policy through rules, regulations, and by-laws. They were to see to it that the inmates were fed a "sufficient quantity" of "common but wholesome" food; were clothed in uniforms that were "comfortable but of course material"; and were punished when necessary, "provided that no cruel or unusual punishment shall be inflicted." 12

The directors were required to visit and inspect the prison at least once a month and were to be paid three dollars per day for their services up to a limit of $\$ 100.00$ per year. As in the case of the superintendent, the state demanded no particular qualifications of the persons who might be appointed to serve as directors. ${ }^{13}$ This fact, coupled with the low salaries, meant that the individuals chosen by the governor would have to be persons with independent sources of income who would likely take care of prison affairs only in their spare time.

Following the passage of the penitentiary act, events moved fairly quickly. The three commissioners selected the town of Huntsville as the site of the new prison and construction began on August $5,1848.14$

$$
\begin{aligned}
& 12 \text { Ibid., pp. } 80-81 . \\
& 13 \text { Ibid., pp. } 80-84 \text {. } \\
& 14 \text { Nowlin, "Political History of the Texas Prison }
\end{aligned}
$$
system," p. 8. 
Although it would take several years to complete all the buildings specified in the original plan, the first prisoner arrived to begin serving his sentence on October 1 , 1849.15

For the first several years of its existence, the population of the prison grew at a relatively slow pace. As of January 1, 1850, for example, there were three inmates confined. By the same date in 1855, the number had increased to 75 and by 1860 , it totalled only 182.16 During these early years there appears to have been no particular problem accommodating all the inmates. 17 Problems did arise, however, in other areas of prison management.

Very early in the life of the prison, the chief executives, along with the prison officials, recognized the reluctance of the legislature to appropriate large

15 Bowen C. Tatum, "The Penitentiary Movement in Texas, 1847-1849" (M.A. thesis, Sam Houston State University, 1970), p. 72; James Robert Reynolds, "The Administration of the Texas Prison System" (M.A. thesis, the University of Texas at Austin, 1925), p. 4.

16 Reports of the superintendent and Financial. Agent for the Texas State Penitentiaries, Embodying the Proceedings of the Pententiary Board, and statistical and Financial Exhibits: Also Reports of Subordinate officers of the Texas State Penitentiaries (Austin: Ben C. Jones, State Printer, 1892), p. 34. 17 Crow, "Political History of the Texas Penal system," pp. 39-40. 
sums of money for penitentiary affairs. Accordingly, Governor P. H. Bell, in 1853, asked the state lawmakers for $\$ 35,000$ to install a cotton and woolen mill in the prison. Bell hoped that this would make the prison selfsustaining financially as well as provide labor for all inmates and thus contribute significantly to their moral reformation. 18

The mill became operational over the objections of Bell's successor, Governor E. M. Pease, who wanted to complete the several workshops in the prison plan and then lease the entire facility to private contractors. The legislature refused to accede to Pease's wishes, choosing instead to implement Bell's plan and make available all necessary monies. By June, 1856, the prison operation consisted of forty looms with 896 spindles for cotton and 200 for wool. When functioning, the mill could process into cloth 500 bales of cotton and 6,000 pounds of wool annually. 19

The investment in the prison mill proved to be a wise one. The cloth products were eagerly purchased by the planters and merchants of Texas, thereby enabling the prison to reduce accordingly the appropriation needed from the state. Under Governor Hardin Runnels' guidance,

$$
\begin{aligned}
& 18 \text { Ibid., pp. 47-48. } \\
& { }^{19} \text { Ibid., pp. 49-50. }
\end{aligned}
$$


the legislature agreed to purchase additional equipment for the mill, hoping to increase prison profits even more. 20 Unfortunately at this point events outside the state became the focus of everyone's attention and ushered in a new period in the history of the prison. During the Civil War, the Texas penitentiary became an institution of critical importance to the state. The inmate population in the period between January 1, 1860 and January 1, 1865 decreased from 182 to 165.21 The reduction in the number of inmates, however, did not affect adversely production from the prison mills.

Prisoner-made cotton and woolen cloth constituted a major source of revenue for Texas during the war. For the period December 1, 1861 to August 31, 1863, for example, Texas prison inmates produced 2,258,660 yards of cotton and 293,298 yards of wool. Selling both to the civilian population as well as the Confederacy, the state earned a total of $\$ 1,174,439.07$. After paying expenses and buying additional supplies, $\$ 800,000$ of the total amount was deposited as earnings in the state

${ }^{20}$ Ibid., pp. 52-54.

${ }^{21}$ Reports of the Superintendent and Financial Agent of the Texas State Penitentiaries, 1892, p. 34 . 
treasury. 22 The wartime prosperity, however, which benefitted both the state and the prison, did not extend beyond the cessation of hostilities.

The end of the Civil War and the defeat of the Confederacy in 1865 also brought a downturn in the fortunes of the prison. The cloth that once had found a ready market as clothing for slaves no longer appealed to Texas consumers. There existed, in addition, chronic problems in procuring sufficient quantities of the raw fiber to keep the machinery in operation. These difficulties, coupled with the rapid increase in the prison population following the war, soon led Texas officials to consider leasing the prison, the most drastic method of penitentiary management ever adopted in the state. 23

22 Crow, "Political History of the Texas Penal System," pp. 62-63.

23 Reports of the Superintendent and Financial Agent of the Texas State Penitentiaries, 1892, p. 34; Crow, "Political History of the Texas Penal system," pp. $85-86$. 
CHAPTER II

EARLY FAILURES, $1867-1878$

The defeat of the Confederate forces in the spring of 1865 and the ensuing years of reconstruction brought many changes in Texas society. Through the remainder of the nineteenth century Texans witnessed the slaves make the often painful transition to freedom while the state received a flood of immigrants from other parts of the South. The economy diversified and grew stronger, adding new wealth to the state. In the immediate aftermath of the fighting, however, the only changes appeared to be for the worse as political unrest and civil turmoil engulfed the state.

Out of the turbulence came fundamental changes in the prison system. The postwar political officials quickly found themselves with an abundance of prisoners and very little money. To solve their dilemma, they decided to lease the prison to outside parties. Although leasing ultimately oroved to be very profitable, the early attempts appear to have satisfied no one. The first decade or so following the end of the 
war brought a near financial collapse of the state government, lawlessness, and a weakening of state government to the point that, at times, it seemed almost incapable of maintaining any control at all. Texas came out of the war with an indebtedness of slightly over eight million dollars. Property taxes formed the major source of income for the state, but poor collection procedures, coupled with citizen reluctance to pay what were perceived as unduly high taxes, resulted in relatively little money flowing into state coffers. One author has described the financial situation of Texas during the immediate postwar period as being characterized by a "large growth of expenditures, great increase in taxation, and the rapid accumulation of a comparatively heavy debt." 1

A picture of the general prostration of the state can be seen by examining certain elements of the postwar economy in Texas. At the end of the war, the state treasury showed a balance of $53,368,510.07$. Of this amount, however, only some $\$ 145,000$ represented currency of any value. The remaincier consisted of worthless, Confederate and state wartime paper issues.

${ }^{1}$ Edmund T. Miller, A Financial History of Texas, Bulletin of the University of Texas No. 37 (Austin: The University of Texas, 1916), pp. 165-166, 195. 
The major industry in the state, agriculture, showed similar reverses. During the perioci 1865-1870, the value of all farms declined by 45.4 percent and cotton production, which had reached 431,463 bales in 1859, had dropped to 350,628 bales ten years later. Along with the reduced production, came a drop in cotton prices from forty-three cents per pound to seventeen cents per pound. 2

The financial plight of the state government, as severe as it was, did not present the only difficulty with which state officials had to contend. Increasing levels of lawlessness also plagued Texas citizens. All sorts of petty offenses increased, as well as the more serious depredations and terror perpetrated by roving bands of briganas that roamed about the state preying on the populace. The statistics on crime for this period are suspect at best, particularly those that attempt to attribute certain crimes to certain groups in society. There seems to be little doubt, however, that the state did, in fact, suffer an alarming breakdown of law and order in the postwar period. 3

2 Ibid., pp. 157-158.

3 Alwyn Barr, Reconstruction to Reform, Texas Politics, 1876-1906 (Austin: University of Texas Press, 
As early ais the fall of 1866, the increased lawlessness became apparent through the larger number of committals to the state penitentiary. Governor James Throckmorton, in an address to the Eleventh Legislature, pointed out that since the end of the war, the prison population had increased from 146 to 264 persons. This had resulted in a serious overcrowding problem. He suggested that the lawmakers consider enlarging the prison facility to handle the growing population. Barring that, he urged a revision of the penal code so as to change the definitions of grand and petty larceny. According to the governor, the prison population could be reduced significantly if persons convicted of stealing goods worth less than twenty dollars were kept in the county jails rather. than sent to the penitentiary. ${ }^{4}$

The legislature chose not to act in accordance with the governor's recommendations. It sought, instead, to relieve the overcrowding by adopting new 1971), pp. 7-8; Charles W. Ramsdell, Reconstruction in
Texas (Austin: University of Texas Press, 1910), pp. 65-70; Ernest Wallace; Texas in Turmoil (Austin: SteckVaughn Company. 1965), pp. 139-146.

${ }^{4}$ Journal of the House of Representatives,
Eleventh $\frac{\text { Jegislature, State of Texas (Austin: Office }}{\text { of the State Gazette, 1866), pp. 86-87. }}$ 
procedures for working the inmates. In "An Act to provide for the Employment of Convict Labor on Works of Public Utility," which was passed on November 12, 1866, the legislature created a body known as the Board of Public Labor to superintend prison inmates. The Board was to be composed of the governor, the secretary of state, the comptroller, the attorney-general, and the treasurer. A majority of three members would constiture a quorum for conducting business. 5

The law required the board to divide the prison inmates into two categories, first and second class. First class prisoners would be those convicted of "murder, arson, rape, horse stealing, burglary, perjury, or robbery." Owing to the more serious nature of these offenses, first class convicts were to be kept at their labors within prison valls. They were not to be worked outside the confines of the prison itself. 6

The second class of convicts would be made up of those persons sentenced to the penitentiary for crimes other than those listed in the first class

${ }^{5}$ Gamme1, Laws of Texas, 5: 1110-1113; "Minutes of the Board of public Labor" (Unpublished manuscript, Archives, Texas State Library, Austin, Texas), p. 3.

${ }^{6}$ Gammel, Laws of Texas, 5: 1110-1111. 
designation. Second class prisoners could be put to work at the board's discretion on "works of public utility." The law contemplated that such works would be found outside the walls of the prison. 7

The law defined "works of public unility" as meaning,

The building of railroads, including. . . the making of the grade, the cutting and laying of ties, and the laying of the track; all works for the improvement of the navigation of rivers, bays, channels, and harbors; for irrigating lands; [and] all workings of mines of iron, lead, copper, or of gold. . . . 8

Second class prisoners also could be employed in iron foundries if railroad iron was being made. The Board was authorized to hire out the inmates on any project that satisfied the definition of public utility regardless of whether the project belonged to the state or was the property of private individuals. ${ }^{9}$

The law made no mention as to the type of housing required for prison inmates who worked outside the prison. In every other regard, however, it sought to keep the prisoners firmly under state control. The state would yield the labor of the prisoners,

\footnotetext{
${ }^{7}$ Ibid.

${ }^{8}$ Ibid.

${ }^{9}$ Ibid.
} 
but not their supervision and care. State agents working directly for the Board of Public Labor would hire and supervise all guards, make certain the prisoners were adequately fed and, by hiring a private physician, would see to the necessary medical care. ${ }^{10}$ This concern and active intervention by state officials to try to guarantee proper care for the prisoners would be one of the more difficult goals to attain.

The rules and by-laws adopted by the Board of Public Labor early in 1867 maintained the spirit of the 1866 act. In clarifying and elaborating on the specific duties and responsibilities of the supervisory personnel, the board manifested considerable concern for the welfare of the prisoners. The duties of guards and physician were carefully spelled out, food requirements were listed, and the hirers of the labor were told the precise amount of time that the prisoners should be worked, reserving a designated hour or hour and one-half for lunch, depending on the season of the year. The board further specified that it preferred to hire out the prisoners in groups of one hunared or more and stipulated that the private contractors would pay

$\because{ }^{10}$ Ibid. 
all expenses incurred in transporting the prisoners from Huntsville to the work site. ${ }^{11}$

At its first meeting, the Board of Public Labor authorized advertisements for bids to hire prison inmates. The ads were run in the Marshall Republican, the Houston Journal, the San Antonio Heraid, and the Galveston Civilian. Bids would be received until February 1, 1867 and notices specified that potential bidders should be interested in hiring the labor for a period of twelve months. Upon receipt of the bids, the board awarded one hundred prisoners to the Airline Railroad and one hundred fifty went to the Brazos Branch Railroad. Both companies agreed to pay $\$ 12.50$ per month per man. 12

Despite the planning and attention given to detail, the minutes of the Board of Public Labor reveal a number of problems in implementing the terms of the contracts. The state agents did not

11 Rules and By-Laws Adopted by the Board of Public [Public] Labor, Relative to Employment of Convicts on Works of Public Utility (Austin: Jo. Walker, State Printer, at the Gazette Office, 1867), pp. 1-8; "Minutes of the Board of Public Labor," pp. $9-18$.

pp. $3-6$.

12 "Minutes of the Board of Public Labor," 
fully unaerstand their duties so were often dilatory in fulfilling their responsibilities. Serious and protracted disagreements arose between the state and the contractors over their respective obligations. State officials, moreover, expressed alarm at the large number of escapes from the railroad camps and the number of men killed or seriously wourded attempting to escape, an indication that guards were not performing their duty in a satisfactory manner. These problems, coupled with a failure on the part of the contractors to make their regular payments, induced the board late in 1867 to begin cancelling the contracts upon their expiration. 13

Even though the contracts made by the Board of Public Labor lasted only a few months, in that short time difficulties surfaced which portended the kind of problems that would plague the state for many years to come. Inherent in the process of hiring

13 Jọn T. Allen, Secretary, Board of Public Labor to President of the Airline Railraod, December 4, 1867, "Minutes of the Board of Public Labor"; Journal of the Reconstruction Convention, which met at Austin, Texas, June l, A.D. 1868 (Austin: Tracy, Siemering and Co., Printers, 1870), p. 772 . 
out state prisoners was a fundamental clash between the interests of the state and the interests of the contractors. The state discovered it could not easily guarantee that its provisions for the welfare and safekeeping of its prisoners would be faithfully adhered to by private parties who employed the prisoners for private gain. State supervision proved especially difficult when the prison inmates were scattered in work camps far from the scrutiny of those officials charged with their welfare.

Upon termination of the contracts with the railroads, the state returned the prison inmates to Huntsville. There the twin problems of overcrowing and expense again became critical and demanded the attention of state leaders. During the time the prisoners had been working for" the railroads, the commander of the Fifth Military District, which included Texas, had removed Governor Throckmorton from office and named former Governor Elisha M. Pease to replace him. ${ }^{14}$ Pease, who had advocated leasing the prison during his earlier term of office, served

14 Barr, Reconstruction to Reform, pp. 7-8; Wallace, Texas in Turmoil, p. 196. 
only until september, 1869, when he resigned.15 During this second period of his service to the state, however, the idea of leasing the prison moved further along the path of realization.

In early summer, 1868, delegates convened in Austin to draft a new state constitution. The convention met in two sessions between June 1, 1868 and February 8 , 1869. The state prison was one of the areas to which the members of the convention turned their attention shortly after the beginning of the first session. 16

The president of the convention, Edmund J. Davis, appointed a committee of five members to go to Huntsville, examine conditions in the prison, and report back to the convention. He urged the committee to look into the finances of the prison, the care the inmates were receiving, the number of inmates, and the types of crimes for which they had been convicted. The report submitted by the committee following its investigation painted a most dismal picture. 17

The committee found that there were more than

${ }^{15}$ Barr, Reconstruction to Reform, pp. 8 ; Connor, Texas, A History, p. 221; Wallace, Texas in Turmoil, p. 210 .

16 Journal of the Reconstruction Convention, vol. 1 , pp. 63,74 .

$$
17 \text { Ibid., pp. 18, 74, 534-535. }
$$


four hundred inmates in the prison and that overcrowding was a serious problem. The prisoners appeared to be adequately fed and clothed, but the crowded conditions made it impossible for the inmates to be provided for in the manner contemplated by the law and the penal code. The report suggested that a good many inmates were either sufficiently reformed or incarcerated under such questionable circumstances that the governor could extend executive pardons and greatly ease the overcrowding. ${ }^{18}$

On the subject of prison finances, the committee had nothing favorable to report. In the past there had been no organized system whatsoever for keeping the penitentiary books and accounts. There was no specified food or clothing ration for the inmates and supplies were routinely purchased and turned over to prison officials with no requisitions, receipts, or other forms of general accountability required. Indeed, no method existed for determining how much of the supplies even reached the inmates. The committee concluded that in the absence of accepted bookkeeping procedures, mismanagement would be an inevitable problem and that in all likelihood the prison would be "a source of great corruption" and a drain on the state treasury. 19

$$
\begin{aligned}
& { }^{18} \text { Ibid., pp. 534-535. } \\
& { }^{19} \text { Ibid., pp. 803-804. }
\end{aligned}
$$


The committee speculated that under proper management the prison ought to make about $\$ 25,000$ per year. To this end, it recommended that the state lease the facility to private individuals who would make regular payments for the labor of the prisoners. The state should retain full authority in the areas of inmate care and supervision, while the lessees would be entitled only to the labor of the prisoners. 20

Governor Pease fully shared the committee's sentiments regarding a lease of the prison. On August 18, 1868, he sent a message to the convention in which he outlined his feelings respecting the prison and its future management. His remarks were very much in keeping with earlier statements he had made on the subject.

Pease pointed out that the indebtedness of the prison system stood at approximately $\$ 50,000$; that since January 1, 1868, the state had had to spend $\$ 14,000$ to meet prison operating costs, and that another $\$ 20,000$ likely would be needed to operate the facility until October 1, 1868. The machinery in the prison could employ only about one-half the inmates, he argued, and the profits from the goods produced were so low as to be hardly worth the effort. He believed that private businessmen could manage the prison more efficiently than state officials

20 Ibid., p. 805 . 
had been able to do. 21

Pease further contended that mismanagement had been the most important factor creating the unsatisfactory state of prison affairs. According to the governor, on September 4, 1866, the date the prison had been turned over to the financial agent appointed by Governor Throckmorton, there had been on hand a stock of goods, material, and money amounting to approximately $\$ 80,000$ over and above all outstanding debts. The Throckmorton administration had so botched things that when the new financial agent appointed by Pease took over in January, 1868, there remained only about " $\$ 1,900$ worth of goods, very few materials, and no money, with debts outstanding. . not far from $\$ 40,000$. . . " 22

Pease concluded his remarks to the convention by suggesting that the body consider leasing the prison to the highest competitive bidder. To provide additional

$$
\begin{aligned}
& { }^{21} \text { Ibid., pp. } 771-773 . \\
& 22 \text { Ibid., pp. } 771-772 \text {. Pease's comments regarding }
\end{aligned}
$$
the management of the prison under his predecessor were virtually identical to those made by each incoming administration throughout the period of this study. All existing problems were blamed on previous administrators while, at the same time, boasts were made that the new management was correcting many of the inherited difficulties. It has proven next to impossible to determine from the reports the financial condition of the prison at any given time. During Throckmorton's tenure of office the illfated attempt to hire out prisoners to the railroads occurred, which, no doubt, placed a drain on the prison financial resources. 
guidance to the convention and, perhaps, to convey the urgency of the situation, the governor also submitted a proposed lease arrangement for the convention members to consider. Although the draft did not make provision for every aspect of a lease agreement, it did, to a large degree, foreshadow the type of contractual agreement ultimately entered into by the state. 23

The Pease proposal would have required the governor of the state to lease the penitentiary for at least five but not more than ten years. The lessees would have had full use of all prison lands, buildings, machinery, and other property and could have directed the labor of the prisoners as they saw fit subject to one stipulation: the prisoners could be worked only within the prison itself. The lessees would have been obligated to take care of state property and to construct such additional buildings as the state might direct at some future time. The proposal made no mention of any amount the lessees should pay the state but did suggest that a $\$ 50,000$ bond be executed as a guarantor of financial capability. 24

Upon receiving the lease proposal, E. J. Davis appointed a special committee of five men to consider the whole matter and make a recommendation to the

\footnotetext{
23 Ibid., pp. $773-775$.

${ }^{24}$ Ibid.
} 
convention. Two of the five committee members deserve special mention. Nathan Patten, a Republican manufacturer from McLennan County, would later develop a personal interest in the lease system and become part of the company with which the state would make the first lease. George T. Ruby, president of the Union League in Texas, had become, without question, one of the more respected black leaders in the state. 25

The committee as a whole, after some deliberation, unanimously recommended the adoption of the Pease lease agreement with certain amendments. The members wanted the lease to be undertaken "without unnecessary delay" and they wanted the lessees to be persons who could hold office under the terms of the Fourteenth Amendment to the United States Constitution, that is, lessees should be persons who had never "engaged in insurrection or rebellion" against the United States. This last recommendation

25 Ibid., p. 775; Wallace, Texas in Turmoil, p. 202; Carl H. Moneyhon, "George T. Ruby and the Politics of Expediency in Texas," Howard N. Rabinowitz, ed., Southern Black Leaders of the Reconstruction Era (Urbana, Illinois: University of Illinois Press, 1982), pp. 372-373. Accounts of the 1868 convention list the delegate from McLennan County as Nathan Patten, a forty-five year old manufacturer. In all the published works on the prison lease, however, the name is given as Nathan Patton, a prominent citizen of Galveston. Chances are very good the two names refer to the same man even though definitive proof of such could not be found. Carl H. Moneyhon, Republicanism in Reconstruction Texas (Austin: University of Texas Press, 1980), p. 244 . 
occasioned some controversy within the committee itself. One of the members, James Burnett, a Republican and former United States Army Captain, objected to the requirement stating that the lease of the prison was a purely business proposition and that matters covered by the Fourteenth Amendment were irrelevant. He ventured that probably a good many people would make excellent lessees even though they were not competent to hold office under the terms of the amendment. In the final vote, the members of the convention disregarded the proposed amendments and approved the original lease proposal. 26

All of the convention efforts on behalf of the prison yielded no immediate results. Governor Pease began to devote increasing amounts of his time to problems he believed to have emanated from attempts by the federal military authorities to meddle in state politics. By September, 1869, his frustrations had reached such a point that he resigned from office. There ensued a period of some four months in which the United States Army General commanding Texas, J. J. Reynolds, assumed the duties of governor. Reynolds finally relinquished control in early January, 1870, to Edmund J. Davis, who had been elected to fill the governor's chair in November, 1869.27

26 Journal of the Reconstruction Convention, vol. 1 , pp. $783-784,832-833$.

27 Wallace, Texas in Turmoil, pp. 208-210. 
Shortly after assuming office, Governor Davis received a report on the prison from Colonel N. A. M. Dudley, who had been appointed superintendent of the facility in November, 1869. The report offered little encouraging news. The prison seemingly had gone from bad to worse. Dudley described the prison as being in a "miserably filthy condition," without money and with very little credit. Nearly nine-tenths of the inmates were kept locked in their cells because there was no work for them to do. Moreover, prison hygiene and sanitation facilities remained in such a poor state that "a great many" of the inmates became ill and would have been unable to work had there been something for them to do. 28

At the time Dudley took control, he found 489 prisoners under his care. During the year 1869, a total of 201 persons had arrived in Huntsville to begin serving their sentences. Those counties sending the largest number of persons to the prison included: Harris county, 24 prisoners, 12 white and 12 black; Galveston County, 41 prisoners, 27 white and 14 black; Bexar County, 15 prisoners, 9 white and 6 black; and Marion County, 10 prisoners, 5 white and 5 black. 29

${ }^{28}$ Report on the Condition of the state Penitentiary. Huntsville, February 10, 1870 (Austin: Tracy, Siemering and Co., Printers, State Journal office, 1870), pp. 5-6.

29 Ibid., pp. 14-17. 
Dudley had managed to convince one local citizen, Dr. W. A. Rawlings, to advance the prison some $\$ 10,000$ worth of cotton on credit so the prison factories could be put into limited operation. 30 such assistance, he reminded the governor, represented only a temporary expedient. Much more money would be needed to get the prison industries running on a solid financial basis. Dudley suggested that something just short of $\$ 125,000$ would be required. 31 He further recommended that a chapel be built in the prison and that a hospital for the treatment of infirm prisoners was desperately needed. Dr. H. C. Oliphant, the prison physician, supported the request for a hospital, noting that under conditions then prevailing sick prisoners were either treated in their poorly-ventilated cells or in the "alleys" through which all the inmates had to pass as they moved about the prison. 32

$$
\text { Dudley's requests for assistance drew virtually }
$$

no response. Approximately five weeks after his report had been submitted, military rule ended in Texas, and shortly thereafter, Governor Davis appointed a civilian, A. J. Bennett, to serve as prison superintendent. The new superintendent, in his first report for Governor Davis

$$
\begin{aligned}
& 30 \text { Ibid., pp. } 5-6 . \\
& 31_{\text {Ibid., p. } 8 .} \\
& 32_{\text {Ibid., pp. } 7,32 .}
\end{aligned}
$$


a few months later, demonstrated quite forcefully the continued decline of the prison. 33

At the time Bennett became superintendent prison finances reached their lowest point. No credit existed for the institution, thus the inmates had to be kept locked in their cells for want of anything to do. The legislature had failed to act on earlier financial requests by the prison officials for appropriations to maintain the prisoners and prison employees. The situation was so depressed that Bennett assumed the state contemplated ending any support for the prison, that the facility would be "no longer an institution of the state. . . "34

Like his predecessor, Bennett went on to request that a hospital be built inside the prison. He also explained that the shortage of cells had made it necessary to house male and female prisoners in the same building. The improprieties which resulted from such an arrangement, he explained, could not be avoided under the circumstances. 35

As for finances, the superintendent stated he had

33 Wallace, Texas in Turmoil, p. 210; Crow, "A Political History of the Texas Penal System," pp. 78-79.

34 Report of the superintendent of the State Penitentiary (Austin: J. G. Tracy, State Printer, 1871), pp. 3-6.

${ }^{35}$ Ibid., pp. 5,17 . 
been able to borrow some money locally to feed the prisoners but much more would be needed to get the prison going again. The looms in the prison factory could make only low-grade cotton jeans and wool garments, commonly called "nigger cloth." The former slaves, now that they were free, would not buy the cheaper grade clothing. Bennett recommended the precise sum of $\$ 247,611.98$ to get the prison factory back into shape to begin earning a profit. Anything less than this would result in the institution remaining a burden on the state treasury. 36 The financial agent of the penitentiary, Louis $W$. Stevenson, confirmed Bennett's estimate of the amount of money needed to revitalize the prison factories, but went on to recommend leasing the prison as the only practical solution. By adopting the lease system, the state would be spared the immense expense "absolutely necessary" to resume factory operations. At the same time, leasing the prisoners and placing them under someone else's care would enable the state to "do away with the large corps of officers and employees . . now required to keep the Penitertiary running." 37

Evidently, the remarks by Bennett and Stevenson impressed the governor. Shortly after receiving their

${ }^{36}$ Ibid., pp. 6-10.

37 Ibid., p. 27. 
report, Davis delivered his message to the Twelfth Legislature and spoke, among other things, of the penitentiary. He told the legislators that the prison was not selfsupporting and could not be made so without major changes of equipment. Large amounts of money would be required to replace existing machinery with a type that could produce a commercially-competitive fabric. Davis went on to note that prison officials desperately needed an appropriation of about $\$ 50,000$ and that additional appropriations would be required to cover the mounting indebtedness of the institution. 38

Acting on Governor Davis' remarks, the Speaker of the House, Ira.H. Evans, appointed Representatives J. W. Lane, R. L. Moore, and Robert zapp as a special committee to examine conditions in the prison and report their findings back to the legislature with appropriate recommendations. The investigation revealed problems similar to the ones discovered by the committee of the Reconstruction Convention some two years earlier. The more serious matters which needed attention included the continued indebtedness of the system, proper care of the inmates, and the need for large amounts of money to restore prison industries. The committee recommended that an appropriation of Texas (Austin: J. G. Tracy, State Printer, 1871), p. 16; Galveston Daily News, January 20, 1871, p. 2. 
large enough to retire the indebtedness be voted by the legislature at once. Since the problem of prisoner care was intimately related to overcrowding, the committee suggested that a law be passed to provide for commuting, or shortening, sentences for good behavior. Such legislation would not only be an inducement to proper conduct on the part of the prisoners, but also would result in a reduction in the number of persons in the prison. ${ }^{39}$

As its final recommendation, the House committee urged that the prison be leased to outside bidders. The members believed this was the only way the system could be made self-sustaining. In advocating lease, the committee strongly urged that the state not abdicate its responsibilities to guarantee proper care for the inmates. The duties of the superintendent should be defined in such a way that they would focus almost exclusively on seeing that the prisoners were not abused or neglected by the private parties that hired them. 40

The Texas Senate, meanwhile, had conducted its own investigation of the prison. The senate committee

${ }^{39}$ Journal of the House of Representatives of the Twelfth Legislature, Part First (Austin: J. G. Tracy, State Printer, 1871), pp. 252, 593-602; Report of Special Committee of Penitentiary, State of Texas (Austin: J. G. Tracy, State Printer, 1871), pp. 7-9.

40 Report of Special Committee on Penitentiary, 1871, pp. 9-10. 
found virtually the same problems as had its counterpart from the House, i.e., no money, sizable debt, and outmoded manufacturing equipment. When senate members confronted the enormity of the problem and considered the amount of money that would be required to make the institution a going concern, they too opted in favor of leasing the entire facility. 41

With the members of both houses of the legislature convinced of the necessity of leasing the prison, events moved rather rapidly. Bills introduced in both houses were quickly passed. After brief deliberations to reconcile any minor differences between the House and Senate versions, the legislature approved the lease bill and Governor Davis signed it into law on March 22, 1871. 42 Texas was thus committed to the convict lease system. The prison facility the state offered to the private bidders in 1871 had changed rather dramatically from its days of prosperity during the Civil War. In addition to the increasingly acute problems concerning

${ }^{41}$ Senate Journal of the Twelfth Legislature of the state of Texas (Austin: J. G. Tracy, State Printer, 1871), pp. 48-52.

42 House Journal, Twelfth Legislature, pp. 534 , 605; Senate Journal, Twelfth Legislature, pp. 139, 453; Report of the Commission appointed by the Governor of Texas, Aprii 10, 1875, to Investigate the Alleged Mismanagement and Cruel Treatment of the Convicts (Houston: A. C. Gray, State Printer, 1875), p. 9. 
lack of money, growing indebtedness, and outmoded equipment, the prison was overcrowded and unsanitary. Furthermore, the state seemed unable to take the kind of action needed to reverse the decline. The decision to lease the entire facility to outside parties clearly represented an admission, albeit perhaps a tacit one, that the state was either unable or unwilling to shoulder its responsibilities toward its convicted felons.

Texas awarded its first prison lease to Ward, Dewey and Company of Galveston. The principal individuals involved in the company included A. J. Ward, E. C. Dewey, and Nathan Patton. All three had reputations as relatively successful businessmen and at least one was very active in state Republican party politics. 43

Patton had been a member of the committee in the Reconstruction Convention that had supported Governor Pease's lease proposal. He also served during Governor Pease's term as the customs collector for the port of Galveston. 44 According to one source, Patton, whose considerable political talents had earned him the nickname

${ }^{43}$ Carl H. Moneyhon, Republicanism in Reconstruction Texas (Austin: University of Texas Press, 1980), p. 158; Galveston Daily News, March 14, 1871, p. 2; Austin Daily Statesman, August 20, 1874, p. 3 .

44 Governor E. J. Davis to Nathan Patton, January 30, 1871. (Davis Letterpress Books, Archives, Texas State Library, Austin, Texas). 
"The Fox," played the preeminent role in Ward, Dewey, and Company. He also was reputed to exert a powerful influence among the directors of the Port of Galveston and the Bolivar Point Wharf and Cotton Press Company. 45

A. J. Ward served as a director of both the Port of Galveston and the Bolivar Point Wharf and Cotton Press Company. In addition, he and Dewey sat on the board of directors of the Texas Mutual Life Insurance Company, which had been chartered by the Texas legislature in september, 1870.46 Ward was present in Austin during most of the time the legislature debated the lease bill. Rumors made him a very strong contender for the lease because of his "large experience with the same duties in other states." 47

The lease law drawn up by the state contained fairly specific provisions. The duties and responsibilities of each party were spelled out and a mechanism was

${ }^{45}$ Galveston Daily News, March 14, 1871, p. 2.

${ }^{46}$ Ibid.; Dallas Herald, September 14, 1870, p. 4; March 11, 1871, p. 2.

${ }^{47}$ Galveston Daily News, March 14, 1871, p. 2; March 18, 1871, p. 2; April 27, 1871, p. 2. The "experience" attributed to Ward was never specifically defined by the newspaper reporter. Other research, however, has revealed that during the early $1860 \mathrm{~s}$, an A. J. Ward was the lessee of the Arkansas State Prison. Ward fled Arkansas in 1863, shortly before the arrival of Federal troops. The temptation is great to assume that the two men were one and the same even though no evidence to substantiate such a belief has been found. Harry Williams Gilmore, "The Convict Lease System in Arkansas" (M.A. thesis, George Peabody College for Teachers, August, 1930), p. 1 . 
established to protect the financial interests of each side. Another provision called for the appointment of a state official to be present in the prison to safeguard the state's interests. 48

The act "authorized and required" the Governor to lease the prison for a period of not less than ten or more than fifteen years. The lessees would have the right to direct the labor of the prisoners and could construct such additional buildings and alter existing structures in any manner they saw fit to keep the prisoners at profitable labor. They were given full use of all lands, buildings, machinery, tools and other property belonging to the prison, with the stipulation that all property was to be kept in good repair. 49

The lessees were required to pay all costs "necessary for the support and maintenance of the penitentiary." This would include all food, clothing, and medical care for the prisoners as well as the salaries of all guards and prison officials. They were further obligated to pay county'sheriffs for costs incurred in transporting prisoners from the county of conviction to Huntsville. The payments to the sheriffs were to be made as they accrued

\footnotetext{
48 Report of the Commission Appointed by the Governor, 1875 , pp. 10-11.

${ }^{49}$ Ibia.
} 
up to a maximum of $\$ 10,000$ per year. 50

Prior to the commencement of the lease contract, there would be an inventory and appraisal of all prison property. The governor and the lessees each would appoint one of the appraisers. In the event these two could not reconcile differences of opinion, they could choose someone to serve as mediator. A similar evaluation would take place upon termination of the lease contract to determine the nature of any final financial settlement between the two parties. To protect the interests of the state, the law required the leasing party to execute a bond payable to the state of at least $\$ 50,000$ but not more than $\$ 100,000.51$

The state's interests in the prison would be supervised by a board of three directors who would appoint a chaplain and a physician. To make certain that the care of the prisoners always conformed to state law, an individual would be appointed to serve as state inspector of prisons. The act required the inspector as part of his duties to submit a monthly written report to the governor discussing the management of the prison and the treatment of the inmates. 52

50 Ibid., pp. 10-14.

51 Ibid.

52 Ibid. 
On April 29, 1871, the state entered officially into a lease agreement with Ward, Dewey and Company. The lessees submitted their required bond on June 9 and took possession of the prison on July $5,1871.53$ The lease agreement gave the prison to the lessees for a period of fifteen years. In return for the labor of the prisoners, the lessees agreed to pay the state $\$ 5,000$ per year for the first five years of the lease. For the next five years, they were to pay $\$ 10,000$ per year; and the amount increased to $\$ 20,000$ per year for each of the remaining five years. These amounts, added to the $\$ 10,000$ per year lessees agreed to pay sheriffs, meant that the lease would have a value of $\$ 325,000$ to the state. 54

Ward, Dewey and Company acquired a prison valued by the appraisers at $\$ 236,099.32$, although it was in a deplorable condition. 55 Directors Strother Green, Peter Royal, and Sandford Gibbs, all long-time residents of the town of Huntsville, described the prison at that time as "being without means, credit, or resources of any kind, and the inmates greatly demoralized by idleness and want

$$
\begin{aligned}
& 53 \text { Ibid., pp. 13-14. } \\
& 54 \text { Ibid., pp. 13-16. } \\
& 55 \text { Ibid., p. } 36 .
\end{aligned}
$$


of discipline." 56

The lessees, in a similar report, spoke of the financial problems and described the prisoners as being confined to their vermin-infested cells, fed only beef and cornbread, and suffering from scurvy. There were no eating utensils of any kind in the prison, "nor had there ever been any." The prison contained 238 cells for 607 inmates with "neither hospital, dining-room, nor chapel." 57 During the first few months of their lease, wardDewey made several improvements. They built a dining room which could be used for church services on sunday, made room for a hospital, built forty additional cells, constructed new workshops, and bought new machinery and equipment for use by the prisoners. By December, 1872, the lessees had the prisoners busy making high quality wool and cotton garments, "furniture, doors, sash, blinds, wagons, boots, and shoes, . . all of which find a good market in Texas." 58 The total prison population had increased to 944 inmates. Of this number, 638 were employed in and about the prison at Huntsville. The remaining 306

${ }^{56}$ Reports on the Condition of the Texas State Penitentiary, for the Years 1871-2 (Austin: James P. Newcomb and Company, 1873), p. 3 .

57 Ibid., p. 5; Report of the Commission Appointed by the Governor, 1875 , p. 40 .

58 Reports on the Condition of Texas State Penitentiary, $187 \overline{1-2}, \mathrm{pp} .3-4$. 
worked on construction crews for the Houston and Texas Central Railroad and the Houston and Great Northern Railroad. 59

The initial burst of activity to improve the prison physical plant met with everyone's approval. The lessees received considerable praise for the manner in which they were managing and providing for the prisoners. Although the prison population had increased substantially during the first year and one-half of the lease, the lessees had encountered few difficulties in housing, feeding, or clothing the prisoners. The Inspector, Ed T. Randle, noted that the lessees were complying with all parts of the lease agreement. The prison was clean, strict sanitation regulations were in force, and illness and disease were at a minimum. Randle mentioned only the perennial problem of overcrowding and urged the governor to take this up with the legislature at the earliest opportunity. 60

The prison physician, Dr. H. C. Oliphant, echoed Randle's kind words for the lessees. According to the doctor, the low incidence of disease was directly attributable to the new sanitation regimen and the ready availability of medical care in the hospital provided. Of the sixteen inmate deaths for the reporting period, nine

$$
\begin{aligned}
& { }^{59} \text { Ibid., p. } 66 . \\
& { }^{60} \text { Ibid., pp. 7-9. }
\end{aligned}
$$


resulted from diseases and infirmities contracted by the prisoners while they were in the various county jails prior to their arrival in Huntsville. Of the other decedents, three died of dropsy, one from consumption, one from tetanus, and one "from the effects of wounds," the nature of which the doctor failed to specify. 61

The three individuals who served as chaplains all acknowledged the good work they had been able to do since a chapel had been provided for them. Attendance at Sunday services was excellent and "quite a number" of the inmates, "entertain hopes of everlasting life." The chaplains did ask the governor to assist them in obtaining an annual appropriation from the legislature to buy books for a prison library so that the prisoners would have a means of filling their leisure hours, "the most gloomy of their prison lives." 62

The general mood of euphoria soon spread beyond the smail circle of state officials responsible for the management of the penitentiary. A leading newspaper of the state, the Galveston News, commended the lessees for having brought about much needed changes in the prison. The life of the average inmate had been improved substantially and at no cost to Texas taxpayers. The paper

$$
\begin{aligned}
& 61 \text { Ibid., pp. 10-11. } \\
& 62 \text { Ibid., ?p. 11-12. }
\end{aligned}
$$


lamented the fact that few people knew or cared very much about prison matters, but asserted that those who did would agree that Texas "has just cause to be satisfied with the experiments instituted by Messrs. Ward, Dewey and Company, and should, both from policy and humanity, enlarge and perfect the system introduced." 63

Despite the general improvement in conditions, two problems of a serious nature had developed. One of these involved the payment of money to the county sheriffs for transporting prisoners to Huntsville, and the other concerned the treatment of prisoners by one of the lessees. As early as August, 1871, Ward-Dewey balked at having to pay the charges incurred by the sheriffs who brought prisoners to Huntsville. Governor Davis wrote to the lessees, quoting that part of the lease contract which required such charges to be borne by them up to a maximum of $\$ 10,000$ per year. The governor said the charges should be paid as the sheriffs presented them and that failure to do so could result in a revocation of the lease. 64 Despite the governor's threats, the problem persisted. Davis heard that Ward-Dewey were discounting the sheriffs bills for payment. He instructed Inspector

${ }^{63}$ Galveston Daily News, May 4, 1873, p. 1 .

${ }^{64}$ Governor Davis to Ward-Dewey, August 10, 1871, Davis Letterpress Books. 
Randle to investigate the matter and inform the lessees that such procedures were illegal and should cease. 65

Davis further instructed the inspector to institute new policies respecting the payment of sheriffs. In a letter to Randle, copies of which were dispatched to all county sheriffs, the governor announced that in the future limits would be placed on the number of guards that could be used to transport convicted felons to the state prison. The number of guards would depend on the number of prisoners to be supervised. In addition, the governor instructed sheriffs to practice economy in their trips to Huntsville. They were to wait until their local courts had adjourned and then bring all persons convicted at that session at one time to the state prison. Davis authorized the prison inspector to examine carefully all requests for payment and to approve only those he deemed to be legitimate. 66

This persistent problem of reimbursing county sheriffs did not attract the serious attention of lawmakers until April, 1879. At that time, the Sixteenth Legislature approved a bill which allowed the state to

${ }^{65}$ Governor Davis to Ed T. Randle, April 10, 1872, Davis Letterpress Books.

${ }^{66}$ Governor Davis to Ed T. Randle, April 10, 12, 1872: Davis to Ward-Dewey, August 28, 1872, Davis Letterpress Books. 
enter into contracts with private individuals to transport prisoners from the counties of conviction to Huntsville. 67 As a result of the contract legislation, the average cost of transporting prisoners dropped from slightly over $\$ 77$ per prisoner to approximately $\$ 39$ per prisoner. 68 subsequent contracts would reduce the price even more. 69

Guaranteeing humane treatment for persons incarcerated in the penitentiary proved to be much more difficult. Despite all the provisions concerning prisoner care in both the state penal code as well as the lease contract, evidence of abuse and neglect appeared soon after the lease system was instituted. In April, 1872, Governor Davis wrote to the inspector that there had been reports that Dewey had been mistreating the prisoners. Davis suggested that Dewey stay away from the inmates and leave all direct relations between prisoners and lessees to Ward,

${ }^{67}$ Gamme1, Laws of Texas, 8: 1439-1440.

68 Biennial Reports of the Directors and Superintendent of the Texas State Penitentiary at Huntsville, Texas with the Report of the Frison Physician, commencing December 1, A.D. 1878 , and terminating October 31, A.D. 1880 (Galveston: The News Book and Job Office, 1881), D. 11 .

${ }^{69}$ Biennial Reports of the Penitentiary Board and Superintendent of the Texas State Penitentiary at Huntsville, Texas with Reports of physician and Chaplain, November 1,1880 to October 31, 1882 (Austin: E. W. Swindel1s, State Erinters, 1382), ?. 7 . 
whom the governor believed to be much more qualified and experienced. 70

In other communications with the inspector, Davis ordered a complete investigation into charges that prisoners working in a railroad camp near Bremond had been brutally beaten by the guards. ${ }^{71}$ In response to a letter from the County Judge in Crockett, Texas, Davis ordered Randle to look into the treatment of prisoners working on the Great Northern Railroad near the East Texas town. According to the Judge, L. W. Cooper, the prisoners were not "half-fed," were made to work on Sunday and required to do more work "than men can do," were "cursed and abused," and were crowded at night into pens "where they suffer a want of ventilation." The prisoners were punished by being placed naked in stocks, raised off the ground and whipped cruelly. The governor wanted all guilty indiviauals in these matters punished severely. 72 Inspector Randle cuickly discovered that complying with the governor's requests was no easy task. The Erisoners, naturally, were reluctant to tell the inspector the truth about their treatment, knowing they might later

70 Governor Davis to Ed T. Randle, April 10, 1872, Davis Letterpress Books.

71 Ibid., February $29,1872$.
72 Ibid., June 11, 1872. 
suffer the wrath of the guards. Moreover, the state penal code specifically prohibited the testimony of convicted felons in legal proceedings. Thus charges could not be filed and prosecutions instituted unless guards testified against their colleagues, a most unlikely prospect, or some local citizen who had witnessed the mistreatment of prisoners came forward to testify. ${ }^{73}$

Reports of the abuse of prisoners by lessees and guards continued throughout the duration of the Ward-Dewey lease. In fact, the evidence of brutality became worse the longer the Galveston company held the contract. By the spring of 1873, however, matters concerning prisoner care were overshadowed by other problems that both state officials and the lessees considered to be of much greater importance.

In their zeal to reestablish prison industries, a process which had involved considerable renovation and construction of new buildings as well as equipment purchases, the lessees found that their expenses quickly outstripped the income from the labor of the prisoners. As a result, in May, 1873 , they appealed to the legislature for a delay in paying money which would be due the

${ }^{73}$ George W. Paschal, A Digest of the Laws of Texas: Containing Laws in Force, and the Fepealed Laws on which Rights Rest (Washington, D.C.: W. H. and O. H. Mcrrison, 1873), p. 531 . 
state under the terms of the lease contract. The state lawmakers, the majority of whom were Democratic, consented to the delay, believing it to be much more important that the prison industries be firmly established and the permanent facilities well-built. Governor Davis vetoed the bill granting the delay, arguing that such action constituted a loan of state money to the lessees and, as such, was constitutionally prohibited. The legislature, however, overrode the governor's veto and permitted Ward-Dewey to postpone payment of both the annual lease sum of $\$ 5,000$ as well as the $\$ 10,000$ annual payment for sheriff's transportation charges. The lessees were authorized to make no payments to the state for the years 1873-1875, but would pay upon expiration of the lease the total sum of $\$ 45,000$ plus 7 percent interest. 74

Having been given something of a financial reprieve, the lessees devoted more of their attention to managing the prison. In 1874, the first Democratic appointees of Governor Richard Coke offered unrelieved praise for Ward-Dewey. The Inspector,.J. K. P. Campbell, considered the Ward-Dewey lease to be a most "fortunate circumstance" for the state. All provisions of the lease contract were fully complied with by the lessees: the

74 Report of the Commission Appointed by the Governor, 1875, pp. 16-18. 
prisoners were well-fed, well-clothed, and adequately disciplined. Campbell even asserted that the prison was "more than self-sustaining" financially. Since no payments were made to the state, he probably meant that enough money was available to provide adequately for prisoners as well as for permanent improvements to the prison facility. 75

The prison directors, J. W. Bush, B. W. Walker, and Thomas J. Goree, fully supported Campbell's assessment of the prison condition. The three men agreed with the inspector's findings and submitted the report to the governor with no alterations. Further concurrence came from Dr. W. A. Rawlings, the prison physician, who said that he had first been associated with the prison during the gubernatorial term of Sam Houston and that at no time since then had the institution seen "better discipline and management." 76

Governor Coke, in a message to state lawmakers during January of 1875 said of the prison:

The management of the penitentiary in all its departments is excellent, the discipline is admirable, because while strict it is humane. The convicts are well-fed and clothed, and are not overworked, and all the apartments and cells in the prison are in good condition.77

75 Reports on the Condition of the Texas State Penitentiary ior the Years 1873-4 (Houston: A. C. Gray, State Printer, 1874), po. 6-9, 13-14.

76 Ibid., pp. 14-15.

77 Governor's Messages, Coke to Ross, edited by and for the Archive and History Department of the Texas State Library (Austin: A. C. Baldwin and Sons, Printers and Binders, $19 i 6)$, p. 84 . 
The governor also commented favorably on the "system, skill, and enterprise" with which the prison industries were managed. 78

Regarding the overcrowding and the resulting necessity of placing prisoners in outside work camps, Coke stated that under the existing conditions little else could be done. The prison at Huntsville simply was not large enough to house the growing prison population. To remedy the situation, he requested that the legislature authorize the construction of additional prisons. He further recommended a house of corrections for juveniles serving their sentences in the Texas prison system. 79

The legislature responded to the governor's message by approving a bill, "to provide for the building and completing of two State Penitentiaries." One of the new prisons was to be build "northeastward of the Trinity river," to exploit the iron ores in that part of the state. The other was to be located west of the Colorado River where state prisoners would engage in the "manufacture of cotton, wool, leather, and other goocis." 80

The western prison would never be built. The commission empowered to locate a site for a prison in

78 Ibid.

79 Ibid., pp. 84-87.

${ }^{80}$ Gammel, Laws of Texas, 8: 400-401. 
northeast Texas ultimately selected a location near the town of Rusk in Cherokee County. ${ }^{81}$ The legislature appropriated $\$ 5,000$ for the initial work to establish the East Texas penitentiary. 82

The general mood of satisfaction with prison affairs, as manifested by the governor and other state officials, failed to reflect accurately the deplorable conditions that existed inside the prison. Indeed, the official statements contrasted so sharply with the true situation as to exceed the bounds of acceptable political hyperbole. Perhaps, state leaders spoke from ignorance and simply repeated information passed on to them by prison officials. Or, possibly, knowing something of the abuses that existed, they preferred, nonetheless, to put the best face forward fearing that to do otherwise would risk a public outcry that would force the state to abrogate the lease. Whatever the case, as charges against the management of the prison began to be heard, state officials were forced to take action.

The criticism of the Texas prison system came from officials in the state of Kansas. According to the superintendent of the Kansas penitentiary, during the

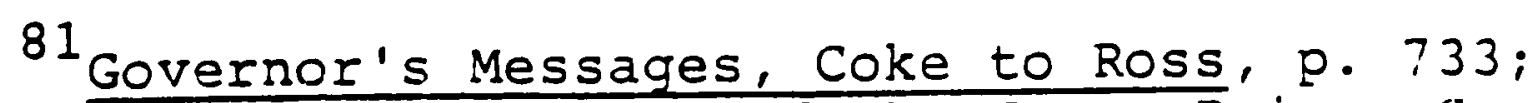
Nowlin, "A Political History of the Texas Prison System," ‥ 31 .
}

${ }^{82}$ Gamme1, Laws of Texas, 8: 403. 
months of July and November, 1874, a group of sixty-seven United States Army prisoners had been transferred from Huntsville to the state prison in Kansas. Upon their arrival, the prisoners appeared to be in a "horrible condition."

Most of them were emaciated and sick, reminding the prison authorities more of returned Andersonville war prisoners than of military prisoners, some of whom had committed only trivial offenses. 83

The prisoners themselves described their treatment as brutal. The food they received was of poor quality, often spoiled, and in short supply. They never had adequate clothing to protect against extremes of weather and were forced to work all day long despite rain, cold, or their physical condition. The cruelties perpetrated against them did not differ substantially from the abuse meted out to all the Texas inmates. The principal culprits included not only guards and sergeants, but the lessees themselves, especially ward. One inmate told of an incident in which ward ordered a hospital attendant not to feed a sick prisoner, while another said ward instructed a prison guard to kill a particular inmate who recently had attempted to escape. 84

Most Texans first became aware of the charges

\footnotetext{
83 Report of the Commission Appointed by the Gcvernor, 1875, p. 68 .

84 Ibid., pp. 68-8i.
} 
made by the Kansas officials in a newspaper article that appeared in the New Orleans Times in March, 1875. The Texas press subsequently picked up the story and generated a good deal of controversy and debate. ${ }^{85}$ Governor Coke, responding to all the publicity, appointed a three-man committee led by the assistant attorney-general to undertake a full investigation of state prison affairs.

The committee members spent two weeks talking with inmates, guards, lessees, directors, and other prison officials. They visited the outside camps where prisoners worked as well as the main prison at Huntsville. Although the committee did not have subpoena powers, it did take all testimony under oath. 86

The committee concluded that there was indeed room for legitimate criticism. The prisoners received insufficient clothing during the winter; they were overcrowded, especially in their sleeping arrangements, and were forced to sleep on bedding that was "disgustingly filthy." Moreover, they were not fed a sufficiently-varied diet. The inmates received generally good medical care but the committee was at a loss for words "sufficiently strong to condemn as inhuman and unfit for the purpose, the place in the Penitentiary miscalled a hospital." The hospital

$$
\begin{aligned}
& { }^{85} \text { Ibid., pp. } 67-68 . \\
& { }^{86} \text { Ibid., pp. } 3-7 .
\end{aligned}
$$


was located on the second floor of a building directly over the kitchen with its large oven and cauldrons. During the summer the heat from the kitchen rendered the hospital virtually uninhabitable. ${ }^{87}$

The committee reserved its strongest condemnation for the manner and the degree to which the prisoners were punished. Even trivial offenses against prison regulations could result in a punitive ordeal so severe that gags had to be placed in the suffering prisoner's mouths to stifle the screams. Guards often inflicted punishment at night so there would be no witnesses to the action. Citizens living near some of the prison work camps stated that "the groans and entreaties of the convicts at night were often so absolutely heart rending as to prevent. . . sleeping." 88

Having defined what it perceived as the major failures of the prison administration, the committee next turned its attention to suggesting remedies. To ease the overcrowding, committee members recommended a house of correction for those inmates under the age of twenty-one years. The committee further argued that too many people were being sent to the prison for theft of items of comparatively little value. It suggested a change be made
87 Ibid., pp. 92-99.
${ }^{88}$ Ibid., 100-105. 
in the penal code to decrease the number of penitentiary offenses but stopped short of making a specific recommendation to that effect. 89

In its concluding remarks, the committee spoke of those fundamental weaknesses in the administrative structure of the prison system which rendered it difficult to prevent mistreatment of prisoners. Committee members pointed out, for example, that it was to the "conduct of guards, more than anything else, that the abuses of convicts may be traced." Yet many of the persons who worked as guards had no qualifications for the job. They were paid only $\$ 20.00$ per month so that many who sought the position did so only as a last resort. Owing to the large number of guards required, the lessees found it impossible to conduct thorough investigations into the character of the persons hired. 90

The committee also criticized the provision in the lease contract that left the salaries of the prison officials to the lessees. The persons who served as guards, directors, physician, and chaplain were supposed to be employees of the state who looked after the interests of the state. By permitting the lessees to control the salaries, however, the lease contract placed state

$$
\begin{aligned}
& { }^{89} \text { Ibid., pp. 127-129. } \\
& { }^{90} \text { Ibid., pp. 133-134. }
\end{aligned}
$$


prison officials in the awkward position of serving two masters. To correct this predicament, the committee recommended that all prison officials be paid directly by the state. 91

On the subject of punishment, the committee recommended that definite procedures be instituted to prevent arbitrary and capricious conduct of guards. Corporal punishment, for example, should be permitted only with the approval of the inspector or one of the directors. In addition, complete written reports of all punishment should be prepared and given to the inspector, who would have the responsibility of keeping them in a permanent file. Any irregularities, such as unauthorized punishment, or the escape or death of a prisoner, should be investigated thoroughly by the inspector and reports made for submission to the proper authorities. 92

Acting on the recommendations of the investigating committee, Governor Coke and the directors drew up new regulations and by-laws for the prison. Specific duties were assigned each officer, with the inspector being given much greater alithority in matters concerning the proper care and discipline of the prisoners. The regulations required all punishment to be carefully supervised, with

$$
\begin{aligned}
& 91 \text { Ibid., pp. 133-135. } \\
& 92 \text { Ibid., pp. 136-137. }
\end{aligned}
$$


no corporal punishment to be administered at night under any circumstances. New reporting requirements were instituted so that the elected public officials could be kept better informed on matters taking place in the prison. The new regulations took effect in late July, 1875.93 In addition to alerting state officials to the necessity of reforms, the committee report represented a watershed in the relations between the state and the lessees of the prison. Following its publication, the two parties to the lease contract seemed bent on a collision course that would result in the demise of the Ward-Dewey lease. The harmonious, mutually-satisfactory state of affairs that had existed prior to the late spring of 1875 gave way to suspicion, mistrust, and recrimination. The citizens of Texas were treated to what must have seemed a bizarre and rather inexplicable about-face on the part of their elected officials, as the laudatory expressions of satisfaction with prison affairs abruptly changed to accusations, heated rebuttals, and reciprocal hostility. Governor Coke grew increasingly critical of the lessees following the submission of the report of the prison investigating committee. The governor expressed

93 Rules and By-Laws for the Government of the Texas state Prison. Adopted by the Board of Directors July 16, 1875, and Approved by the Governor, July 22, 1875 (Houston: A. C. Gray, Princer, 1875), Dp. 4-6, $\overline{11-12}$. 
anger at the number of prisoners who either had been killed or had escaped. He wanted a full report from Inspector Campbell on each death. Coke stated that the large number of escapes from the prison reflected "inexcusable mismanagement. " 94

The governor also wanted the inspector to make certain that all inmate deaths were followed by a proper legal inquest and wanted the name of the presiding judicial officer in each case. Campbell was instructed particularly to see that the lessees fully honored those parts of the lease agreement and the penal code which sought to guarantee humane care of prisoners, including adequate medical treatment. ${ }^{95}$ To assist Inspector Campbell in his duties, Governor Coke appointed Henry $\mathrm{K}$. White of Ennis to serve as assistant inspector of the prison. 96

Dissatisfaction with the prison management under Ward-Dewey also began to appear in other arenas of state affairs. In early September, 1875, delegates met to write

94 Governor Coke to J. K. P. Campbell, May 5, 1875, Coke Letterpress, Archives, Texas State Library, Austin, Texas.

${ }^{95}$ Governor Coke to J. K. P. Campbell, May 5, 1875; June 32, 1875; July 3, 25, 1875; December 11, 1875, Coke Letterpress.

96 Governor Coke to H. K. White, November 27, 1875, Coke Letterpress. 
a new state constitution to replace the one drafted in 1868.97 In calling for the constitutional convention, Governor Coke referred to the 1868 document as an "extremely defective instrument, . . . " Many of its provisions were "repugnant . . oppressive . . [and] at war with the view of proper policy of the people of Texas." It had been written at a time of political turbulence when the threat of federal intrusion into state politics loomed large. In 1875, however, Texas citizens no longer feared "Federal interference" and could draft a governing document more to their liking. 98

Shortly after the convention assembled, it launched its own investigation of the prison. The investigation findings asserted that reform of the inmates was virtually impossible under the management of Ward-Dewey and that no matter how stringent the rules and regulations providing for inmate care, they would be essentially unenforceable as long as prisoners were scattered about the state in isolated camps. State leaders should take positive steps, such as establishing a house of corrections, commuting sentences, and decreasing the number of penitentiary offenses. The results of such policies would

97 Journal of the Constitutionai Convention of the state of Texas, 1875 (n.p., n.d.), pp. 35-38. Copy located in the library of Texas Tech University.

98 Governor's Messages, Coke to Ross, p. 73. 
likely reduce the prison population to such an extent that additional prisons would be unnecessary. The convention concluded its report by warning state officials to take immediate action with regard to the prison as there was a strong possibility that at any moment it would, "suddenly be thrown back upon the State." 99

The arrival of the new year, 1876, brought a continuing decline in the fortunes of Ward-Dewey. In separate reports the inspector and the directors scored the lessees for their poor management of the prison and their failure to carry out all the provisions of the lease contract. The reports deemed Ward-Dewey to be unfit for the responsible positions they held and pictured them as being indifferent, if not completely callous, to the numerous cruelties perpetrated against the prisoners in their care.

In the inspector's report, Campbell did little more than reiterate the charges and complaints made against the lessees in the 1875 investigative report, to wit: Ward-Dewey were not complying with the provisions of the iease contract. The inspector explained the large number of escapes as resulting, in part at least, from the practice of placing prisorers serving long sentences, those with little left to lose, at work

${ }^{99}$ Journal of the Constizutional Convention, 1875, p. $170-174,541-542$. 
in the outside camps. Campbell concluded his report by urging that the governor resume possession of the prison. The lessees had demonstrated their inability or unwillingness to manage the prison properly as the law provided so that humane considerations and "the good name of our state" left only one recourse--resumption. 100

The director's report carried much the same message as had that of the inspector. All admitted that the prison was being run poorly but the directors attributed much of the lessees' failure to a critical shortage of money needed to put the institution on a sound footing and not to any deliberate intention to ignore responsibilities. They pointed out that the penitentiary was, under any circumstance, a costly and unwieldy institution and would likely remain so no matter who administered it. The implication in their message was that resumption might not be the answer to all the problems. 101

The directors additionally noted that a serious conflict of authority existed between the lessees and the

100 Report of the Condition of the Texas State Penitentiary for the Years 1874, 1875, 1876 (Houston: A. C. Gray, State Printer, 1876), pp. 4-5, 7-9, 12-13, $15-17,20-21$.

${ }^{101}$ Report of the Board of Directors of the Texas State Penitentiary to the Governor, March, 1876 (Houston: A. C. Gray, State Printer, 1876), pp. 6-10. 
inspector and that possibly this had been the cause for much of the problem in prison management. The rules and by-laws adopted in July, 1875 had given the inspector considerable power to act against guards who were either brutal in their handling of prisoners or incompetent. Yet the lessees paid the guards' salaries. The directors reasoned that the only way to solve this dilemma was either to leave discipline exclusively to the lessees or have the state pay the guards. 102

Within a few weeks of the directors' report, WardDewey submitted a report of their own in response to all of the criticism. In a tone that revealed a curious sort of contentious bewilderment, the lessees seemed to be at a loss to explain the attacks made against them. All of the reports on the prison prior to the early months of 1875 had been very good. In late spring, of that year, however, following the Kansas report, the mood of state officials had changed. The same inspector and directors who had worked so closely with the prison and who had found so much to compliment just a few months earlier began to find much to criticize. Using the 1874 and 1876 inspector's reports, the lessees pointed out the complete reversal of opinion concerning the same topics and

$$
102 \text { Ibia., p. } 6 .
$$


material. 103

Ward-Dewey concluded their appeal to the governor by admitting that they had encountered many difficulties with the lease of the prison. The severe economic crisis which had begun in late summer, 1873 had forced cancellation of many work projects, leaving them with over a thousand prisoners who were idle but who, nevertheless, had to be fed and cared for. This had placed a severe financial strain on their resources. The lessees argued that their losses had been such that it likely would be at least a year, or perhaps two, before they could recover financially, but at that future time they would be willing to return the prison to the state. 104

The lessees' appeal had little effect in reversing, or even slowing, the growing antipathy toward the lease. The die having been cast, events proceeded along an inexorable path to resumption. The next step came when the Fifteenth Legislature, which convened in mid-April, 1876, sent yet another investigating committee to examine

\section{Report of the Lessees of the Texas State Peni-} tert-ary, April, 1876 (Houston: Telegraph Steam Book and Job Frint, i876), pp. 3-8; Report on Condition of the Texas State Penitentiary, 1873-4, 0.13 ; Report on Condition of the Texas State Penitentiary, 1874, 1875, 1876, po. 4-6, 12-13, 16-17.

204 Report of the Lessees of the Texas Etate Penitentiaxy, $1 \overline{876}$, pp. 23-28. 
prison affairs under the lessees. 105

The report submitted by this committee simply restated the findings of earlier investigations. WardDewey's management of the prison in all its aspects was roundly condemned and the state was urged to assume its responsibility. The final blow came on August 19, 1876, when the legislature approved a bill requiring the governor to abrogate the lease and resume possession of the penitentiary, "at such time and in such manner as he may deem necessary or expedient. . . "106

The state did not immediately resume possession of the penitentiary. Following passage of the resumption bill, there ensued lengthy deliberations between the state and the lessees seeking to determine the nature and size of a final financial settlement. An appraisal of all prison property, including all permanent improvements

105 Journal of the House of Representatives of the State of Texas, being the First Session of the 15th Legislature, begun and held at the city of Austin, April 18, 1876 (Galveston: Shaw and Blaylock, State Printers, 1876), pp. 395-402.

$$
{ }^{106} \text { Ibid.; Gamme I, Laws of Texas, 8: 1029-1032. }
$$

The Galveston Daily News charged that during debate on the bill to cancel the Ward-Dewey lease, Representative William Lang of Falls County led the pro-lease forces. The paper hinted that Lang, Worthy Master of the state Grange, had succumbed to the "accomplished and genial friends" of the lessees and had fought to defeat the bill abrogating the lease. In response to the charges, Lang said he was not trying to protect Ward-Dewey, but was interested only in "having some twenty or thirty convicts" to work his place. Galveston Daily News, June 8, December 19,1876 . 
made during the lease period, was initiated. The lessees, fearing that their interests might be jeopardized or, at least, not considered equal to the interests of the state, hired legal counsel to protect themselves. 107

Further delays came when, in the midst of the resumption negotiations, the state changed governors. On December 1, 1876, Governor Coke resigned to accept a seat in the United States Senate. Upon Coke's resignation, the mantle of state leadership passed to the LieutenantGovernor, Richard B. Hubbard. Governor Hubbard on April 2, 1877, officially took possession of the state penitentiary and ended the Ward-Dewey lease. 108

In assessing this first lease of the state prison, a somewhat clouded picture emerges. It is extremely difficult to measure how well, or how poorly, Ward-Dewey administered the prison. There can be no doubt but that problems existed. Everyone, even the lessees, admitted this. Given the general agreement that difficulties existed, however, raises the more important question of whether the problems were so severe as to warrant terminating the lease? The availabie evidence suggests that they were not.

\section{$107 \mathrm{~J}$. S. Duncan, "Richard Bennett Hubbard and} State Resumption of the Penitentiary, 1876-1878," Texana 8, No. I (1976): 47-55.

$$
108 \text { Ibid., p. } 48 \text {. }
$$


The charges that prisoners under the lessees had been abused and neglected no doubt were true. Similar charges had been made during the late 1860's, before the Ward-Dewey lease, when prisoners were worked on the railroads of the state. They continued to be voiced during the administration of Governor Davis, after the lessees took charge of the prison. Indeed, charges of cruelty toward prisoners would be characteristic of all leases made subsequent to Ward-Dewey. The fundamental conflict of interest in the leasing arrangement made abuse and neglect of prisoners a distinct possibility. The only way such mistreatment could have been reduced significantly would have been for the state to end all leasing of prisoners, a proposition state officials did not seem willing to entertain seriously in 1877 .

It could be argued that the state terminated the lease for financial reasons. Certainly the lease contract did not generate the amount of money state legislators had hoped it would originally. Ward-Dewey admitted difficulties in this regard. Even though the state did not make the kind of money contemplated in the lease agreement, however, neither did it have to spend much. Even during theis worst financial periods, Ward-Dewey continued to maintain the prison withcut an appropriation from the state legislature. The state only experded nonies during the lease for some of the sheriffs' charges for 
transporting prisoners to Huntsville. Since neither prisoner mistreatment nor finances would seem to have been reasonable causes for ending the lease, the answer must lie elsewhere and state politics appears to be a more fruitful area of inquiry.

The same political factors and conditions that had motivated Governor Coke to convene a constitutional convention in 1875 also influenced penitentiary affairs. The Republican administration of Governor Davis had been voted out of office. The reemergence of the state Democratic party by 1873 , and its subsequent capture of the governorship, had ushered in, as Coke suggested, a movement to rewrite the Republican laws and alter state government along lines more acceptable to the majority of the state's citizens.

Just as the Democratic leaders disliked the Republican constitution of 1868, they probably disliked the prison lease made under Davis to a firm with strong Republican ties. Political partisanship seems to offer a reasonable explanation for the abrupt, almost astonishirg, change of attitude toward the lessees by state officials in late spring, 1875. The contract with Ward-Dewey became simply another part of the Republican legislative legacy that was to be swept away by the resurging Democrats.

Adaitional evidence for the political aspect of 
resumption came several years later. In March, 1883, Senator A. W. Terrell addressed his senate colleagues on the subject of renewing a lease with the firm of Cunningham and Ellis, to whom the state had awarded the prison in 1878 in the first long-term arrangement following the passing of Ward-Dewey. Terrell, who opposed all leasing of prisoners, stated that the original lease with cunningham and Ellis had come about, at least in part, as a result of efforts to "chrystallize" political majorities. He also mentioned financial gain for the state as a consideration, but the political factor, to Terrell, seemed quite clear. 109

The lease made with Ward, Dewey and Company reflected the desperate condition of affairs in state government in the first decade or so following the Civil War. A disrupted economy, bankrupt treasury, and growing criminal population pressed state financial resources to the limit. Elected leaders, when confronted with the enormous problems before them, chose to lease the prison in the hope that in addition to providing for the prisoners, the lessees also would make regular payments to the state.

Or balance, the lease cannot be considered to have i09 ${ }_{\text {Taxis Siftirgs, }}$ 2, No. 47 (March 32, 1833): 6 . 
been a success. The lessees encountered serious financial difficulties and had to default on their payments. In addition, the manner in which the prisoners were treated left much to be desired. For these reasons, especially the prisoner treatment, state officials said they had no choice but to revoke the lease and resume possession of the prison.

Other factors also came into play in the state's decision to end the lease. It appears that political partisanship played a prominent role. The Ward-Dewey lease had been made during the administration of the Republican, Edmund J. Davis. Shortly after the Democrats regained political preeminence in the state they began to find serious fault with the Republican lease and ended it in the spring of 1877. The Democrats then had the responsibility for making a new lease or taking other steps to handle a prison population that exceeded the capacity of the prison. 


\section{CHAPTER III}

\section{THE SUCCESSFUL LEASE, 1878-1883}

The termination of the Ward-Dewey lease provided state officials with an opportunity to make a fresh start with the prison system. Upon resuming control of the prisons, state officials negotiated a temporary lease for six months to gain time to prepare for a much longer and more profitable arrangement. Ultimately, the prison passed into the hands of a South Texas company led by E. H. Cunningham and L. A. Ellis, both of whom had extensive land holdings and other business interests. The , Cunningham and Ellis lease proved to be very profitable for both the state as well as the lessees. In fact, the profits led a number of state leaders to argue against an extension of the lease in 1883 so that the state could resume control and keep all the money generated by the labor of the prisoners.

When the state resumed control of the prison in 1877, general economic conditions, though somewhat improved, remained a source of concern for elected officials. Agriculture, both farming and ranching, had rebounded a Iittle from the lows of the immediate postwar period, but 
the state continued to struggle with financial difficulties. The heavy indebtedness of earlier years could not be retired with a system of taxation that, owing to the ease of evasion, yielded little revenue. State leaders found their options for managing state institutions limited by shortages of money in the general revenue fund. 1

Governor Hubbard had anticipated the financial problems involved in managing the prison and had interpreted liberally the provision in the resumption bill which authorized him to resume in any manner he deemed "necessary or expedient." Hubbard reasoned that before the state could solicit bids for a new long-term lease, it first would have to complete a full appraisal of all prison property, decide the terms under which a lease would be made, make public notice of bidding procedures, and allow a sufficient amount of time for interested persons to consider the state's offer. The governor believed it could easily take several months before all the preparations for a new lease could be completed and during that time the state would have to bear the expense of supporting the prison. ${ }^{2}$

${ }^{1}$ Miller, A Financial History of Texas, pp. 196239. pp. $727-7 \overline{28 .}$

${ }^{2}$ Governor's Messages, Coke to Ross, 1374-1891, 
To relieve the taxpayers of such a burden, Hubbard decided to accept the offer of a Galveston firm, Burnett and Kilpatrick, for a temporary lease of the prison. The company had contacted the governor earlier and offered to enter into a short-term agreement in which it would pay all expenses of the prison plus additional monthly payments at the rate of $\$ 20,000$ per year. In return for their money, Burnett and Kilpatrick would employ the prison inmates for their financial benefit. Hubbard believed that the temporary lease "was the best thing that could be done under the circumstances." To administer the state's interests under the new lease Hubbard appointed Judge James E. Shepard of Travis County, I. T. Gaines of Lamar County, and $H . K$. White, the former inspector, of Ellis County, to serve as directors. Thomas J. Goree of Huntsville joined these three as Hubbard's appointee for superintendent. 3

${ }^{3}$ Ibid., p. 728; Governor Richard Hubbard to Thomas J. Goree, March 22, 1877; Hubbard to Burnett and Kilpatrick, March 24, 1877; Hubbard to Messrs. Shepard, Gaines, and White, March 26, 187\%, Hubbard Letterpress Books, Texas State Library and Archives, Austin, Texas.

Perhaps because the Burnett and Kilpatrick lease was of a temporary nature, not much evidence has been found describing it. In the 1878 biennial report, superintendent Goree mentioned that the lease wert well for the first four months, with "very few complaints, and none . . Grounded. . . " During the iatter months, however. there were numerous criticisms in regard to lack of proper food and clcthing. Goree specisically attempted to absolve the iessees of any guilt in these matters, saying that "whatever theif [Burnett a Kilpatrick] delinquercies may 
In awarding the temporary lease to Burnett and Kilpatrick, Governor Hubbard provoked a controversy that ultimately hurt him in his bid for reelection. A few months after the lease was made, a leading newspaper in the state published an article which charged that Hubbard gave the prison to Burnett and Kilpatrick in return for certain financial favors. The publicity surrounding the disclosure forced Hubbard to respond publicly to the accusations. 4

The governor stated that he had awarded the lease to Burnett and Kilpatrick "partly" because he had done business before with one of the lessees, J. H. Burnett. Hubbard explained that Burnett owned a cotton commission house in Galveston and that for several years this house had marketed the cotton grown on Hubbard's 700 acre farm in Smith County. The governor denied that he had profited from the lease and pointed out that the firm of Burnett and Kilpatrick was different from the Burnett cotton

have been, they were aue to other causes rather than to lack of disposition to comply with their contract and with the rules of the prison." Unfortunately, the Superintendent failed to offer any explanation for the problems. Biennial Report of the Commissioners and superintendent of the Texas state Penitentiary at Huntsvilie, Walker County, Texas, December 1, 1878 (Galveston: Book and Job Office of the Galveston News, 1878), p. 5.

${ }^{4}$ J. S. Duncan, "Richard Bennett Hubbard and State Resumption of the Penitentiary, 1875-78," Texana 12 , No. I $(1974): 53$. 
commission business even though J. H. Burnett was a principal in both companies. As his ultimate rebuttal, Hubbard asserted that had he been in a position, and of a disposition, to profit personally from the lease he would not have made it a temporary arrangement. 5

Since the Burnett and Kilpatrick lease was destined to last only a few months, state officials prepared for a long-term contract in the fall of 1877. Governor Hubbard decided that the new lease should begin on January 1, 1878 and should run for five years. Advertisements announcing the state's intentions and scliciting bids were published "in a large number of the leading newspapers in and outside of the State. . . " To guard agains possible charges of favoritism, or political chicanery, in the bidding process, the governor directed that all bids were to be mailed in sealed envelopes and addressed to the secretary of state. The bids wolld be opened by the secretary in the presence of the governor, the attorney-general, and "all such bidders or their representatives as desired to attend." After receiving a total of nine bids, the governor, in December, 1877, awarded the prison to Ed H. Cunningham of Guadalupe county, who was the "highest and best

5 Ibia.; Dallas Herald, January 5, 1878, p. 3; George R. Nielsen, "Richard Bennett Hubbard, 'The Demostheres OE Texas" (M.A. thesis, The University of Houston, :95i), po. jう-j9. 
bidder. . ." Shortly thereafter, and with the permission of Governor Hubbard, L. A. Ellis of Jefferson, Texas became associated in the lease with Cunningham. Cunningham and Ellis agreed to pay the state $\$ 3.01$ per month per prisoner for the lease of the prison. 6

Ed H. Cunningham and L. A. Ellis were both men of some wealth and prominence in late nineteenth century Texas. Cunningham, originally from Arkansas, had come to Texas in 1856. When the Civil War broke out, he organized a company of troops which later became part of the Fourth Texas Regiment. Cunningham ultimately attained the rank of Colonel in the Regiment and completed his military service as Inspector General under General John Bell Hood. 7 L. A. Ellis, a native of Mississippi, came to Texas in 1859 and opened a mercantile business in Jefferson. He too served with the Confederate forces during the war. Following the end of the war, Ellis began purchasing farm land in Fort Bend County where he also engaged in merchandizing. Cunningham and Ellis are considered to have been two of the more prominent pioneers in establishing the sugar industry in Texas. ${ }^{8}$

${ }^{6}$ Governor's Messages, Coke to Ross, pp. 730-731; Duncan, "Richard Hubbard and Resumption of Penitentiary," 2. 53 .

7 San Antcnio Express, August 28,1912, p. 2.

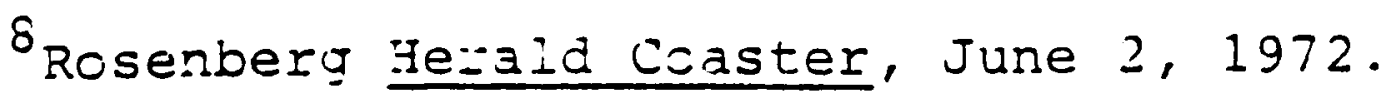


The lease agreement drawn up between the state and Cunningham and Ellis contained many features that had appeared in the Ward-Dewey lease contract. Other parts of the agreement, however, sought to correct some of the problems that had developed in the earlier lease. The comparative success of the Cunningham and Ellis venture may, in part, have been the result of the provisions in the lease agreement itself.

Cunningham and Ellis received the prison for a period of five years, commencing January 1, 1878, Specifically, the contract gave them the

State penitentiary at Huntsville, together with all the property . . . real, personal and mixed, pertaining or incident thereto, whether within or without the prison walls, and the labor of all the convicts now belonging or hereafter to be sent. . . .9

The lessees were prohibited from sub-letting the lease, or any part of it, without the written consent of the governor. ${ }^{10}$

The contract required the lessees to keep all prison buildings and property in good repair and to feed, clothe and work the prisoners in accordance with the rules and by-laws of the prison system. They were further

9 "Bond of Lessees of Texas State Penitentiary, Under Lease made January 1, 1878," Unpublished manuscript in Penitentiary Papers, Texas State Library and Archives, Austin, Texas, p. i.

${ }^{10}$ Ibia. 
obligated to hire good, reliable guards and to dismiss any guard when requested in writing to do so by the superintendent or one of the directors. This last provision quite obviously sought to prevent the kinds of conflicts that had arisen between the state and Ward-Dewey involving brutal or incompetent guards. 11

Cunningham and Ellis also agreed to pay the salaries of all state prison officials. The methods of payment differed from earlier experiences, however, and were instituted specifically to permit the state personnel to feel much greater freedom of action as they went about their duties. Instead of having salary payments come directly from the lessees, the money was to be paid into the state treasury where checks would then be issued to the prison officials. The lessees were to pay $\$ 730$ per month for the combined salaries of the directors, superintendent, physician and chaplain. ${ }^{12}$

Further requirements placed on the lessees included providing cffice space and stationery for the superintendent and directors as weil as sufficient paper and postage for the prisoners to write one letter per week. Upon completion of their term of incarceration, the prisoners were to receive from tire lessees a suit of

$$
\begin{aligned}
& 11 \text { Ibid., p. } 3 . \\
& { }^{12} \text { Ibid. }
\end{aligned}
$$


plain civilian clothes, a pair of shoes, a hat, and $\$ 20$ in cash. Finally, the lessees had to make bond in the amount of $\$ 100,000$ as a protection for the state. 13

When the prison was turned over to Cunningham and Ellis, it had an appraised value of $\$ 239,002.86$. This included the main prison at Huntsville along with all lands, machinery, tools, and supplies. The lessees invested much time and effort during their lease constructing new facilities and improving existing structures so that by the end of the lease period, they returned to the state a prison system of considerable value. ${ }^{14}$

The first major evaluation of the prison under Cunningham and Ellis came in early December, 1878. Superintendent Goree stated that the lessees were providing "active and energetic" leadership to make their lease a success. Both men were described as being "kind hearted and humane. . . " They did not force the prisoners to labor unduly hard, nor did they permit any abuse of the prison inmates. 15

According to Goree, Cunningham and Ellis "always

13 Ibid., pp. $1,3$.

14 Biennial Report of the Penicentiary Board and Superintendent of the Texas State Penitentiary at Huntsville, Texas with Reports of Physician and Chaplain, November 1880 to October 31,1882 (Austin: E. W. Swindells, State Printers, 1882), p. Ij.

15 Biennial Report, 1878 , pp. 5-6. 
evince a willing and ready compliance with the rules." The lessees provided good medical care for the inmates and more clothing than had ever been the case in the prison, even though there had been problems with some items of winter clothing. Satisfaction with the food, the superintendent observed, exceeded anything he had seen in his four years with the prison system. 16

All punishment inside the prison at Huntsville came under the jurisdiction of Goree. Authority to discipline the outside work forces, however, lay within the purview of the board of directors. Within the prison, the usual forms of punishment included the stocks, the dark cell, the ball and chain, and "occasionally whipping," which was administered only on orders from the board of directors and only under the direct supervision of the superintendent. Goree reported that there had been relatively little punishment during the early period of the Cunningham and Ellis lease. Most inmates were amenable to a light reprimand, or the withholding of some minor privilege, as punishment for an infraction of the rules. Moreover, the prisoners felt that the days of the arbitrary and excessive reprisals on the part of the guards were over, "that no unnecessarily harsh or cruel punishments will be inflicted, and that all punisiments are for just causes." 17

$$
{ }^{16} \text { Ibid. } \quad{ }^{17} \text { Ibid., P. } 7 .
$$


On the topic of discipline Superintendent Goree demonstrated most clearly his preeminence among the many superintendents of the prison system during the period of this study. He continually evinced considerable concern over the objectives of punishment and, of equal importance, the best way to achieve those objectives. Goree admitted that he had much to learn about discipline and the best means of obtaining it. He requested that higher state officials also give this matter some thought and consider making available a small sum of money to enable Texas prison officials to visit and observe similar institutions around the country. He hoped to learn from what others were doing and incorporate what he learned into his management of the Texas prison. 18

$\Gamma$ Goree further recommended that a commutation or, "good time," law also be requested of the legislature. He had in mind a legislative enactment that would permit a reduction in sentence for every prisoner who manifested good conduct during his period of incarceration. Goree reported that such laws were already in effect in most other states and that all reports indicated their "good effects upon the discipline of the prison and conduct of the prisoners." 19

18 Ibid.

19 Ibid. 
Regarding working the prisoners in camps outside the main prison, the superintendent recognized the necessity of such action and the likelihood that the situation would not change in the foreseeable future. The greatest objection he saw to such an arrangement was "the temptation offered to convicts to escape, and the great number of escapes which occur." This proved especially true of white prisoners working in the railroad construction camps, in saw mills, and chopping wood. The largest percentage of escapes came from the small camps scattered about the countryside, while in the larger outside forces, escapes were relatively rare. Goree thus recommended that white prisoners be worked with the spur, or shackles, and that "the lessees be requested not to hire out forces in less numbers than twenty, and to give preference to such hirers, other things being equal, who will take the largest number not exceeding sixty." 20

Goree reported that he had established procedures for keeping records in the various prison departments, many of which had not kept records before. There had been problems of long stancing, for example, in getting

20 Ibid., p. 8. The spur was a tight-fitting metal collar placed around the ankle. There were prongs pointing downward toward the foot. The prisoner wearing the spur was not preventec from walking or working, but running was impossible. Galveston Laily News, JuIy 5, 1879, p. 1. 
accurate reports from the outside work camps. As a result, during the latter part of the Ward-Dewey lease, Inspector Campbell had shown 184 prisoners unaccounted for. Goree had begun requiring the sergeants in charge of the outside camps to send him a monthly written report showing the name and number of every prisoner in their care, along with information on the numbers of deaths, escapes, and punishment. With the new reporting system, Goree had reduced to 44 the number of inmates whose whereabouts were unknown. 21

Dr. Thomas W. Markham, the prison physician, also spoke favorably of the new lessees. Nothing "conducive to local sanitation has been overlooked or neglected." The prisoners had been properly clothed, "plentifully supplied with wholesome, nutritious food, and an abundance of pure cistern water." The new hospital rooms, which had been moved from over the kitchen, were "commodious, wellventilated and well-supplied with all needed appliances for the comfort and welfare of the sick." There had been but one recent epidemic in the prison and that was of a "mild type of measles. . . ." Doctor Markham urged legislative action to remove the criminally insane prisoners incarcerated at Huntsville. According to the doctor, no way existed to treat such persons properly in the main

\footnotetext{
$21_{\text {Biennial Report, }}$ i878, p. 9.
} 
prison among the general inmate population. Hr recommended "the erection of a suitable building, near the Lunatic Asylum at Austin, where the patient could be placed under the care of physicians who make the treatment of diseases of the mind a specialty." 22 The presence of the criminally insane among the general inmate population generated much complaint from prison officials. Little relief was forthcoming, however, and throughout the period of this study the more violently insane remained within the prison walls. F As of December 1, 1878, there were 1,738 persons serving sentences in the Texas prison system. This figure showed an increase of 150 individuals over the 1,588 incarcerated at the time ward-Dewey surrendered their lease. Cunningham and Ellis employed the prisoners in the following manner:

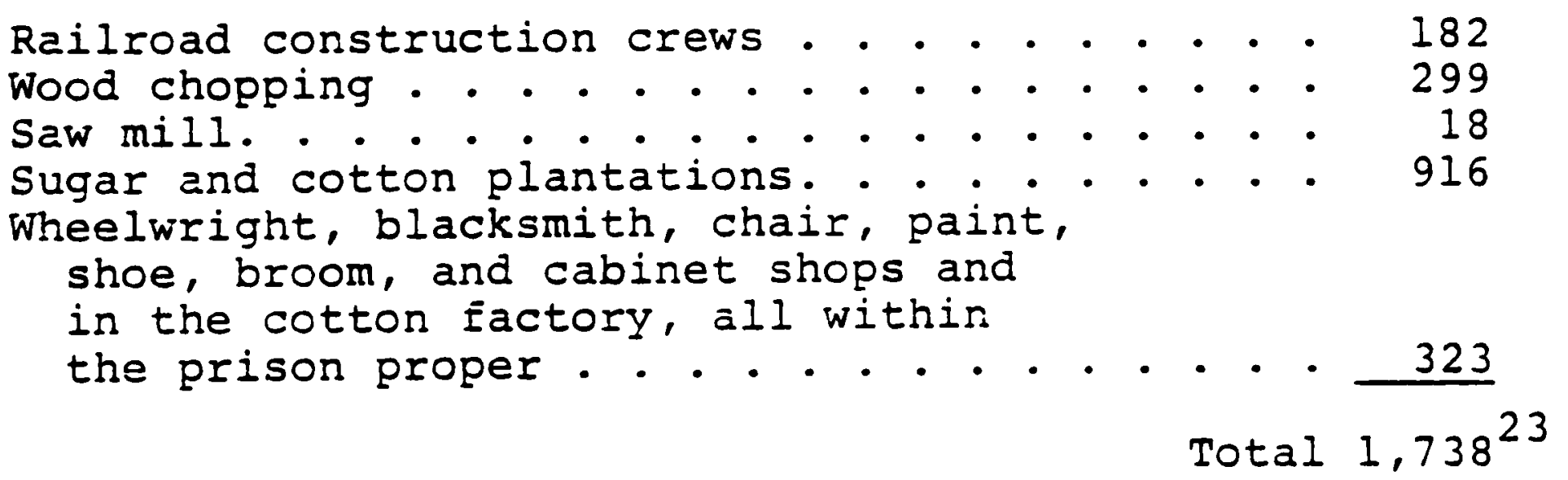

For the period January through November, 1878, the state earned a total of $\$ 56,718.98$ from the Cunningham

$$
\begin{aligned}
& 22 \text { Ibid., pF. } 6,10-11 . \\
& 23 \text { Ibid., D. } 13 .
\end{aligned}
$$


and Ellis lease. The monthly amounts owed to the state by the lessees varied with the fluctuating prison population, from the lowest figure, $\$ 4,706.23$, in January, 1878 , to the greatest monthly amount, $\$ 5,621.97$, paid in November. 24 Governor Hubbard reported that the Cunningham and Ellis lease had paid more "actual cash" into the state treasury during the first year than had been received in the entire history of the institution prior to that time, and "for the first time in the history of this institution does it yield a clear profit." 25

The report on the first year of the new lease must have come as very welcome news to public officials who had watched almost helplessly as the prison system declined precipitately and floundered amidst seemingly insurmountable burdens. Cunningham and Ellis had tackled the problems forthrightly and seemed to be making progress toward establishing the system on a sound economic footing. The superintendent had instituted new procedures designed to improve the overall administration of the system so that it would ultimately become a more efficient, competent agency of state government. In addition, he had begun to think about various reforms which would enable the prison to function more smoothly and therefore better serve the

$$
\begin{aligned}
& 24 \text { Ibid. } \\
& 25 \text { Governor's Messages, Coke to Ross, p. } 732 .
\end{aligned}
$$


interests of the individuals imprisoned as well as the state.

The Sixteenth Legislature, meeting in the spring of 1879, reacted to the new professionalism in the prison by responding favorably to the requests made. In a bill passed in March, state lawmakers formalized the administrative structure of the prison by amending certain parts of the state penal code and the Cunningham and Ellis lease agreement. The new law brought together in one document the policies and regulations regarding prison management that had evolved separately in a somewhat haphazard manner over several years. The nature and limits of the authority and responsibility of each prison official were carefully delineated and new policies concerning prison inmates and their care were defined. 26

The new law required the governor to appoint three persons, subject to senate confirmation, to act as directors of the prison. The directors would serve two year terms and their duties included the responsibility for establishing all rules and regulations of the prison. They could set up any policies they deemed "proper and necessary" and all sich policies would be binding upon all prison employees. Directors were to meet in formal session at ieast three times per month to confer on

${ }^{26}$ Gammel, Laws 0 ETexās, 8: 1347-1357. 
matters relating to the prison and its management and were to submit to the governor a written report of their meetings. 27

The directors were also required to inspect the prison at least three times per month and to investigate all complaints made by the prisoners. They were authorized to "administer oaths, summon, and examine witnesses" as part of their effort to settle disputes and correct abuses. They were to report to the governor for his action any complaints or allegations of improper conduct on the part of the superintendent or any lessees. 28

The superintendent, as the chief executive officer of the prison, received responsibility for carrying out the rules and regulations established by the board of directors. He was to be appointed by the governor, with the consent of the senate, and would serve for two years. The superintendent would have "general supervision and control" over all prisoners and guards and could remove any of the latter for failure to perform their prescribed duties in a satisfactory manner. Additional duties of the superintendent included: responsibility for the maintenance of discipline in the prison; frequent visits with the prisoners to make certain they were "humanely

$$
\begin{aligned}
& 27 \text { Ibid., pp. 1347-1348, } 1354 . \\
& 28 \text { Ibid., pp. 1347-1348. }
\end{aligned}
$$


and properly treated"; and keeping accurate records of each prisoner and his behavior. Furthermore, the superintendent should report monthly in writing to the governor, "showing the management of the penitentiary and the character of the treatment and discipline of the prisoners." He should also maintain all prison books and accounts to show the amount of money coming into the prison and the amount going out. 29

To assist the superintendent, the governor was required to appoint an assistant superintendent whose job it would be to oversee the outside camps where prisoners were employed. He was to visit the camps at least once each month to determine the care the prisoners were receiving and prepare a written report giving complete information on each of the camps. The reports should include the names and numbers of prisoners in the camps, the nature of their care, and full details of escapes and inmate deaths. 30

Those individuals hired as guards would be selected by the directors upon nomination by the superintendent and would be compensated "for their services as the directors may prescribe. . . ." All guards would receive their pay from the state and could be dismissed

$$
\begin{aligned}
& { }^{29} \text { Ibid., pp. } 1348-1350 . \\
& { }^{30} \text { Ibid., p. } 1350 .
\end{aligned}
$$


from state service by the superintendent "on account of inefficiency or misconduct." The law listed no qualifications for guards except that they had to be qualified voters of the state. 31

On the topics of prison discipline and prisoner treatment, the new law made its most drastic departure from the preceding statutes. The state appeared intent on correcting some of the more obvious areas of neglect and mistreatment of the past. Prisoners would have a broader range of opportunities available to them provided their conduct comported with prison regulations.

After making the usual acknowledgments as to the state's responsibility for providing suitable clothing and food, the law outlined the new policies respecting the treatment of prisoners. Inmates were to be treated with "humanity, and a distinction. . made in their treatment, so as to extend to such as are orderly, industrious and obedient, comforts and privileges according to their deserts." Prisoners would not be forced to do more labor than their "physical health and strength may render proper," and no work would be required of those persons deemed medically unfit by the prison physician. Finally, no prisoner would be forced to labor on Sunday,

${ }^{31}$ Ibid., p. 1352 . 
unless it was "absolutely necessary." 32

The law also attempted to make available to prison inmates opportunities for self-improvement they might not have had before. Those persons who were unable to read and write when admitted to the penitentiary would be permitted to receive instruction during the study period, "under such regulations as the directors may prescribe." The directors were authorized to hire a teacher to instruct the prisoners. 33

On the subject of punishment, the new law listed the means by which refractory conduct could be controlled. Prisoners disobeying regulations would be subjected to "closer imprisonment, confinement in irons, deprivation of privileges, and other punishments of like character," except that no prisoner would be denied food at regular meal times. Whipping would be the punishment of last resort and could only be carried out "upon the special order of the directors in particular cases. . . " The law further stipulated that a prisoner's head colild not be shaved. 34

In addition to prescribing punishment for those persons guilty of breaking the rules, the law also

$$
\begin{aligned}
& 32 \text { Ibid., 卫. } 1352 . \\
& 33 \text { Ibid. } \\
& 34 \text { Ibid., ‥ } 1354 .
\end{aligned}
$$


T provided rewards for those who "evince a purpose of reformation and a disposition to obey the rules of discipline. . . " Good conduct could result in the commutation of the sentence being served. Prisoners who obeyed the rules could earn a specified number of days off their sentence for each month "in which no charge of misconduct is sustained. . ." For their first year prisoners could earn two days per month off their sentence. This number would increase at the rate of an additional day per month up to the maximum of fifteen days per month for any period of good behavior longer than nine years. For every sustained charge of misconduct, however, the prisoner would lose one month's time of that year, and all commutation time would be lost in the event the inmate participated in a mutiny, conspiracy, or escape. ${ }^{35}$

The lessees would have the right to employ the prisoners either within or without the prison, "but no convict shall be hired or put to labor outside the walls when his labor can be utilized within the wails." The superintendent and directors could, if they chose, decide which classes of prisoners could be worked outside the prison and could formulate any other policies in this regard that they deemed proper and useful. In conclusion, the legislature stipulated that by January 1, 1880, "or as

${ }^{35}$ Ibid., 2p. $1353-1354$. 
soon thereafter as possible," all prisoners should be confined at work inside one of the penitentiaries. 36

The reorganization of the prison system under the 1879 law represented a substantial step forward for the state. Serious problems of all the usual varieties would continue to plague prison administrators for a good many years. But by assigning specific responsibilities to the individual state officers, a sense of order and stability was introduced. The state was maturing as a political entity and one sign of that was the effort to foster greater competence and efficiency in the administration of state agencies. The provision in the 1879 law that called for all prisoners to be within the walls by January 1, 1880, or as soon thereafter as possible, proved to be an illusion. It could have been achieved only had the state been willing to embark upon an enormously expensive construction program to build additional prisons. Once the prisons had been completed, additional expenditures would have been necessary to establish industries and put them on a proficable basis. The state had begun only recently to enjoy the Einancial fruits of a successful lease. It is too much to expect that state cfficials would have reversed their course and ended ar arrangement that was proving to be so profitable.

$$
{ }^{36} \text { Iวid., ?. } 1355 \text {. }
$$


The stated intention to work the prisoners within the walls probably represented a response on the part of the lawmakers to a growing public concern over placing prisoners in outside work camps. During the last year of his administration Governor Hubbard had received several petitions from citizens groups that were upset and angry because prisoners were being put to work in their counties, thereby taking jobs from local people. A group of 313 residents of Longview wrote the governor asking him to "stay the avaricious hand of the monopolists" who were bringing prisoners into Gregg county and taking the means of livelihood from the local citizens. One hundred and twenty-four residents of Harrison County, one of them the county attorney, protested the use of prison labor to cut cross ties for the Texas and Pacific Railroad in their county. The petitioners estimated that such work could provide employment for 500 of their fellow citizens. From 695 people in Bowie Couniy came protests of a recent contract which had enabled Cunningham and Ellis to use prisoners in clitting Euel wocd for the railroads. The lease contract had deprived approximately 500 Bowie Dourty residents of employment and had given the jobs 1 to men "upor. whom the state has passed condemnation." 37

${ }^{37}$ Citizens of Gregg County to Governor Richard rubbard, AEril 24, 1873; Citizens of Harrison Colnty to Governor Eubbard, fẹril 20, 1878; Citizens of Bowie 
Concern over the growing public resistance to the use of prisoners in outside labor forces continued to be manifested by Hubbard's successor, Oran M. Roberts, who had been elected governor in November, 1878. Late in his second term, Roberts wrote to the prison superintendent expressing his fear that the public outrage on this subject was "getting strong and widespread." Roberts anticipated a storm of public protest unless state officials took some action to mollify the critics. The governor admitted to the superintendent that no part of the state government had caused him such "constant uneasiness and apprehensions" as the prison system and especially the treatment afforded prisoners in the outside camps. 38

Those sections of the prison reorganization bill which sought to guarantee humane treatment and care for the prisoners proved to be as difficult to enforce as such provisions had been in earlier legislation. State officials had to be vigilant constantly to detect mistreatment. Once abuse or neglect was reported, it had to be attested to by witnesses whose testimony would be accepted in a court of law. Yet they were not always

County to Governor Hubbard, no date, Hubbard Papers, Governor's Letters Received.

${ }^{38}$ Governor 0 . M. Roberts to Superintendent T. J. Soree, December 13, 1881, Roberts Letterpress Bcoks, Texas state Library ard Archives, Austin, rexas. 
available. Nor was it always possible to believe those persons who came forth to speak against the lease and the practice of working prisoners in outside camps.

Very early in Roberts' administration, reports came in of severe abuse of prisoners working in a wood-cutting camp near Mineola. Governor Roberts responded by ordering the superintendent and assistant superintendent to undertake a complete investigation of the matter. The investigation and its findings are worth examining in some detail, although this was neither a typical investigation nor one of the more thorough ones. It is worth examining because it demonstrates quite clearly the complex of conflicting opinions and statements that had to be sifted thoroughly to try and get at the truth.

The incident first seems to have come to Governor Roberts' attention in late June, 1879. The governor recounted to Goree the information he had heard and told the superintendent to investigate the matter thoroughly. He recommended that Goree have the assistant superintendent, D. M. Short, go to Mineola and mix with the people to see what could be learned of public feeling regarding the alleged mistreatment. 39 In a subsequent letter to short, Roberts again repeated his desire that the investigation

${ }^{39}$ Governor Roberts to Goree, June 27, 1879, Roberts Letterpress Books. 
be as thorough and complete as possible. He specifically told Short to search out and make contact with senator Buchanan, who represented the area in the state senate. According to Roberts, Buchanan was a reliable man who could be of great help. 40

Shortly before the investigation began, the Wood County flag ran a special edition describing the prison camp in the area and the treatment given the inmates. The paper charged that the prisoners were completely at the mercy of guards who were "heartless brutes in the shape of men," and who were guilty of "unnecessary cruelty, brutish treatment, and outrageous conduct toward the convicts." It recounted stories of numerous unmarked convict graves near the camp, of convicts being whipped to death, and of guards unnecessarily and deliberately shooting and killing men who attempted to escape. The paper called for an immediate investigation to determine the truth in all of the rumors and charges made against the camp administration. 41

Shortly after publication of the Flag extra edition, the Galveston Daily News ran a similar article. It detailed stories of brutal treatment of state prisoners

4i] Governor Roberts to D. M. Short, JuIy 15, 1879, Roberts Letterpress Books.

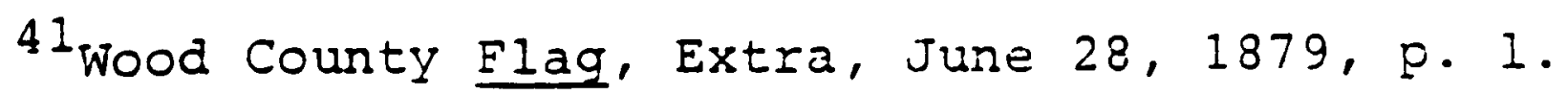


under the care of the lessees. One prisoner, Ed Johnson, had attempted to escape but had been quickly recaptured near the camp because the metal spur bound to his foot made it impossible for him to run. The two guards who had chased him simply shot and killed him rather than take him back to the camp. According to the paper, there was solid evidence to indicate that Johnson had been killed after he was already in the guards' custody. The reporter pointed out that a large percentage of citizens in and around Mineola resented having the prison camp in their midst and that this resentment might lay at the bottom of much of the hostility. The people were angry that the work being done by the convicts denied jobs to free citizens in the area. To them the camp seemed to exist solely for the profit of the lessees with no thought being given either to the reformation of the prisoners or to the safety of the people living near the camp. 42

The paper quoted the attorney for the lessees, a Mr. Giles, who argued that the reasons underlying the criticism of the lessees in wood County were primarily economic in origin. Local people resented seeing the prisoners do work that county citizens could perform. Since state prisoners were performing the work, no addiEional money in the form of salaries made its way into

42 Galveston Daily Nervs, July 5, 1879, p. 1 . 
the Wood County economy. Giles further pointed out that there had been no public outrage regarding treatment of prisoners as long as local people had been able to supply the prison camp with needed goods and commodities, but when Cunningham and Ellis began contracting for supplies outside the area, the local citizens became upset and began complaining of abuse of prisoners. 43

Superintendent Goree and Assistant Superintendent Short, with the aid of Senator Buchanan, conducted the official investigation between July 15 and 18, 1879 . They focused on the alleged abuse and mistreatment of prisoners in a work camp at Lake Fork, near Mineola. The camp contained approximately eighty prisoners (the number fluctuated owing to escapes, discharges, and deaths), who were engaged in cutting wood for the Texas and Pacific Railroad. The camp was supervised by a sergeant and as many guards, usually eleven, as were necessary to control the men and keep them at their work. 44

Twenty-nine persons appeared before the investigating committee. All testified under oath and signed written transcripts of their testimony. The inquiry focused most sharply on the period september 1 to December 24 , 1878, when the camp had been supervised

\footnotetext{
43 Ibid.

44 Ibid.
} 
by Sergeant J. H. Randle. During this time period most of the alleged abuse and neglect of prisoners had taken place. 45

Only eight witnesses offered solid, eyewitness testimony of mistreatment. The others could only repeat rumors they had heard from friends and acquaintances around town. Two of the witnesses, 0. C. Reeves, a bookkeeper, and B. F. Read, a merchant in Mineola, had signed a petition calling for an investigation of the camp even though they had not personally seen any mistreatment of convicts. As justification for their actions, they argued that since it had become known that an investigation would be made, there had been no further reports of bad treatment of prisoners. This led them to believe that they had been correct in their actions and that the rumors had had at least some element of truth in them. 46

The investigating committee called as its first witness Willie Donahue, 17 years old, who had worked as a guard for Sergeant Randle. Donahue had been paid $\$ 18$ per month salary while working as a guard. He stated that he had once seen Sergeant Randle kick an Indian prisoner two

${ }^{45}$ The report of this investigation is found in an unpublished, untitled, handwritten synopsis of testimony, Penitentiary Papers. Texas State Archives and Library, Austin, Texas.

46 Ibid., pp. 17-22. 
or three times because the Indian had said he was sick and could not work. Randle forced the prisoner to go to work anyway and he died later that day. No doctor was called to attend the man before his death. Donahue furIther testified that he had seen Randle place men in the stocks and whip them with limbs from persimmon trees when they said they were too sick for work. He mentioned that the convicts were required to cut a specified amount of cordwood each day. White prisoners were to cut threefourths of a cord, while black convicts had to cut one Lull cord. 47

The next witness, James Long, aged 49 years,

Cstated he had seen Randle leave a man in the stocks for over six hours. The stocks, as described by Long, were made of wood with holes for the convict's neck and arms. Sergeant Randle would place the men in the stocks and raise them off the floor. The prisoners would just be able to reach a small stake in the ground with their toes to relieve some of the pressure on their neck and arms. 48 Long went on to describe some of the incidents he had witnessed. He said he had seen Sergeant Randle use dogs to chase men who were attempting to escape. He would $\Gamma$ permit the dogs to attack the prisoners after recapture.

$$
\begin{aligned}
& 47 \text { Ibid., pp. } 1-2 . \\
& 48 \text { Ibid., p. } 4 .
\end{aligned}
$$


Long said he personally had seen two men whose bodies were badly torn and chewed by the dogs. He had seen two other prisoners each of whom had cut off one hand to keep from having to work, but they were forced to continue working anyway. He did not mention any medical attention the two men might have received. Long concluded his testimony by stating that the men seemed to be well-fed, both in terms of the quality and quantity of food, but were housed in filthy quarters. 49

Dr. A. L. Patton, a physician in Wood County, confirmed much of Long's testimony. He said that the men were greatly neglected during illness and that he often had seen Randle force the men to work when they obviously were unable to and should have been given medical treatment. Dr. Patton testified that during the fall of 1878 there had been a great deal of sickness and disease throughout the entire county. In spite of this, Randle had not taken any extra measures to provide the kind of medical treatment needed to protect the camp inmates. 50 Two of the witnesses, J. W. Richardson, Jr. and W. A. Kennon, had worked as guards at the camp. They said they had often seen men vomit and soil themselves while hanging in the stocks. Kennon testified that he

$$
\begin{aligned}
& { }^{49} \text { Ibid., pp. 4-5. } \\
& { }^{50} \text { Ibid., pp. 5-6. }
\end{aligned}
$$


had seen Randle place a man in the stocks shortly after the man had been shot in the back while trying to escape. Both men agreed that conditions in the camp had improved considerably since Sergeant Randle had been relieved of duty. 51

At one point in the proceedings superintendent Goree took the stand to testify regarding his actions in the matter. Goree stated that he had first heard of the abuse of convicts at Lake Fork in December, 1878. He then had contacted several prominent citizens in Mineola to ask what they knew. At the same time, he had ordered some of the guaras from a nearby camp to look into the matter as well. When their reports confirmed the rumors, Goree asked I. T. Gaines, a commissioner of the prison system living in Paris, Texas, to go to Mineola and make a full report with recommendations for further action. Gaines' report charged Sergeant Randile and one of his guards, F. P. Bounds, with "gross violations of the rules." Gaines recommended that Superintendent Goree ask the lessees to relieve the two men from duty and appoint a new sergeant to command the camp. When this had been done, goree ordered the new sergeant to make a complete repcrt of all violations of the rules with a copy going

${ }^{5 i}$ Ibid., pp. 33-41. 
to a local magistrate for possible criminal prosecution. According to Goree, the sergeant's report confirmed all of the instances of abuse and neglect which had been testified to before the investigating committee, as well as many others not mentioned. Goree concluded by saying that he had done all he could have in the matter as he did not at that time have the authority either to appoint or remove sergeants and guards. 52

Several of the witnesses who could not testify to mistreatment of the convicts by guards did offer evidence as to the mood of the people of Mineola regarding the camp. T. F. McDaniel, deputy sheriff of Wood County, said that virtually everyone he knew objected to permitting the convicts to work outside the main prison and that most believed that convict labor took work away from free workers. D. C. Williams, editor of the Wood County Flag, agreed with McDaniel's assessment. Williams said that as far as he knew, fully nine-tenths of the people in the county opposed having the camp near them. He further stated that he had used his paper to try as best he could to represent that sentiment. 53

At the conclusion of the investigative hearings, Goree ard short filed a report of their findings with

$$
\begin{aligned}
& 52 \text { Ibid., op. } 28-j 1 . \\
& \equiv 3 \text { Ibid., op. 7-11. }
\end{aligned}
$$


Governor Roberts. They concluded that all the publicity given the Lake Fork Camp had developed out of deep-seated and widespread hostility to convict labor on the part of local citizens who desired to use the example of gross mismanagement under Sergeant Randle to discredit and destroy the entire leasing system. They did not deny that much abuse and cruelty has attended Randle's tenure as sergeant, but defended their actions in having him removed as soon as they had verified that he had misused his authority. Goree did mention that the inspector who normally visited camps in the area had been ill through much of the fall, 1878. Thus he had not been able to keep a close check on operations. He also informed the governor that Senator Buchanan had spoken at some length with local prosecutors who believed there was not enough solid evidence upon which to base an indictment or conviction for any of the parties involved in the prison abuse. 54

Shortly after Goree and Short filed their report, Cunningham and Ellis prepared one of their own. In

$\Gamma \quad 54$ Superintendent Goree to Governor Roberts, July 19, 1879, Roberts Pafers.

Striztly speaking, since no eyewitnesses testified to having seen Randie or any of the guards actually kill a prisoner, the prosecutors could do very little. There had been. tesinony to certify abuse and neglect but only as part of the accepted means of disciplining prisoners. The testimony indicated viniations pf prison procedures bixt not tie penal code. And Randle had been discharged, the proper cour zules and regulations. 
essence, they wanted the governor to use his influence to prevent further harassment of their employees, the sergeants and guards, who, it was alleged, were simply doing their jobs. They admitted that they had been deceived by Sergeant Randle, whom they referred to as a "cruel and unprincipled man." But they argued that they had acted responsibly by dismissing him as soon as they had become aware of his activities. They further explained that every time one of their guards was accused of mistreating convicts, it had proved to be very costly to everyone. The charges had to be investigated, the convicts had to be locked up and kept from working while the investigation was underway, and traveling costs and attorney fees had to be paid. 55

The lessees reported that they had encountered considerable hostility along the entire line of the Texas and Pacific Railroad. This opposition, in their view, came primarily from ex-convicts, ex-guards, private woodcutting contractors, and relatives of persons in the lease camps. These people, ail with narrow personal or selfish motives, eageriy talked to the press and ralated all manner of outrageous stories with iittle ragard for the truth. The tone 0 i the report from the iessees

\footnotetext{
5E Cunningham anci EIIis to Govirnor Roberts, July
} 24, 1879, Roberts Papers. 
implied that if some form of relief was not forthcoming soon from the governor's office, they might have to consider terminating the lease. This would force the state to resume control of the convicts and find housing and work for them. 56

The investigation at Mineola seems to have satisfied no one. It did not silence the critics of the lease system. It did not bring an end to the practice of working prisoners outside the prison, nor did it result in any indictments or convictions. It embarrassed the state and the prison officials and demonstrated quite convincingly that mistreatment of prisoners in remote work camps was virtually impossible to prevent, notwithstanding all the legislation designed to accomplish that end.

Governor Roberts, by demanding a full investigation of the wood County matter, maintained his determination to see that the ruies and regulations of the prison system were fully obeyed. On at least three other occasions, the governor ordered the prison superintendent to check into complaints made regarding the treatment of prisoners. In one of the incidents, a tirirteen year old Flack youth had been sent to the prison for theft. Upon his arrival, he was told by the officer in charge that he aid not "want no [sic] children here, it won't pay."

56 i⿻is 
Whereupon the boy was whipped and sent back home. Roberts instructed Goree to investigate the matter and prepare a report of his findings. 57 On another occasion, the governor ordered Goree to check into possible abuse of prisoners working on the International and Great Northern Railroad near Grapeland. Roberts wanted the truth of the allegations determined and instructed the superintendent to take charge of the investigation. In the event Goree could not go, he was to send Assistant Superintendent Short who, like Goree, was also an attorney. 58 In a matter involving possible mistreatment of prisoners in some of the coastal counties, Governor Roberts not only ordered a thorough investigation, he even suggested the manner in which it should be conducted. Roberts wrote Goree telling him that several citizens alleged brutal treatment of prisoners in the camps in Brazoria, Matagorda, and Fort Bend counties. According to the Governor's information, the prisorers were whipped severely, were not fed an adequate diet, and were subjected to generally abusive treatment by the guards. Roierts suggested that Goree have the camps inspected and then, about a week later, arrance for anotiner surprise inspection to see if anything was

57 Governor Roberts to Superintendent Goree, April 22, 1880, Roberts Letterpress Books.

58 Governor Roberts to Superintendent Gcree, December 4, 1881, Roberts Letierpress Books. 
amiss. The superintendent was instructed to hire private investigators if necessary to determine the truth of the charges. 59

$\Gamma$

The continued mistreatment of prisoners, especially those working outside the prison, made a virtual mockery of the legislation designed to protect the inmates. The laws were only as effective as the officials in charge (of the camps chose to make them. The superintendent, working with the lessees, was able from time to time to bring about some improvement. But the situation represented a dilemma in which despite all the effort expended, a certain amount of abuse could not be prevented.

Recognition of the problems in the outside camps occasioned some of the few negative comments about the Cunningham and Ellis lease. Superintendent Goree reported in 1880 that the lessees had cooperated with him as he attempted to enforce compliance with the regulations, but that much remained to be done to bring the camps up to the desired level. Apart from this, however, the superintendent offered much to please state officials.

The prison directors, S. R. Smith, J. W. Carey and $J$. M. Wynne, believed that considerable progress in the management of prison affairs had been made during the

\section{${ }^{59}$ Governor Roberts to Superintendent Goree,} December 2, 1881, Rcbercs Letterpress Books. 
first two years of the lease. The lessees had completed a number of construction projects to improve the main prison at Huntsville, including the building of a strong wall to surround the entire facility. The brick wall formed a rectangle 500 feet by 778 feet in length, had a foundation of four feet, was 32 inches thick, and varied in height from 18 feet to 26 feet above the ground. There also had been improvements made in the cell buildings, the dining room, and the guard houses, and a residence had been built for the superintendent, who was required by law to live in the prison. The total cost of all the improvements came to approximately $\$ 52,000$. The directors recommended that the superintendent's salary be increased from $\$ 1,500$ to $\$ 2,000$ per year and that some provision be made to establish the position independent "of political changes and party bias of every kind." This request represenced not only a tribute to Goree, whom the directors considered to have "few if any equals as a prison executive in any state. . ." but was also a policy that had been adopted in "several older states" and had produced satisfactory results. 60

60 Bienniai Report, 1880 , pp. $5-9$.

There hac been a wall around part of the Huntsvilie facility prior to the construction of the new one jy Cunningham ard Eilis. The arciltect who designed the new wall, J. Larmour of Austin, examined the existing wall and decided it was sibstandard and that security consideration aimanded a new one. The accuragy of his 
Goree revealed that the state was doing very well financially from the lease. The net proceeds for the period December 1, 1878 to November 1, 1880 totalled $\$ 186,910.97$. In addition, Cunningham and Ellis had made permanent improvements to the prison buildings and structures in the amount of $\$ 224,331.11$, including $\$ 120,000.00$ for the construction of the East Texas penitentiary at Rusk. The lessees had paid an additional $\$ 47,029.18$ for the recapture of escaped prisoners, salaries of prison officials, and money and transportation for those inmates who had been discharged from the prison. 61

The proven profitability of the lease may go far toward explaining why state officials felt so much concern over the treatment given the prisoners in the outside camps. Humanitarian considerations aside (and these were not inconsiderable), the state achieved a distinct advantage by seeing that the prisoners were not treated cruelly or permitted to escape and terrorize the countryside. Horror stories of guard brutality and mistreatment of prisoners, or frequent escapes, could stir up public opinion against the lease system and force elected officials to end it and have to resort to taxation to support

assessment became obvious to everyone when, as the workmen began demolishing the old wall, "it $f \in i l$ nearly the whoie length, the workmen barely having time to escape from under it."

$$
{ }^{6} \text { Ibid., pp. 10-11. }
$$


the prisoners.

The prison population as of November 1,1880

totalled 2,157, an increase in 23 months of 419 . The prisoners were employed in the following manner:

In Huntsville prison proper . . . . . . . . 342

Constructing Rusk prison. . . . . . . . . . 256

On railroad construction crews. . . . . . . . 156

Cutting wood. . . . . . . . . . . . . . 215

At Kelly's Ironfurnace--Marion County . . . . 104

On farms. . . . . . . . . . . . . . . 1,045

Miscellaneous . . . . . . . . . . . .

Total 2,157

The prisoners confined within the prison proper at Huntsville included men with over fifteen years to serve, those possessing trades, those considered "notoriously bad," and those judged to be physically unfit for outside labor. 62 The prison industries continued to be successful, especially the furniture, wheel-wright, shoe, and harness shops. These four produced the most goods and the work was of high quality. The prison cloth factory still had not been modernized, so it continued to turn out a fabric "for which there is but little demand. . . ." Goree explained that the lessees had not invested much money in the cloth factory because "the term of lease is too short, and the uncertainty of legislation too great to justify the cost." 63

Discipline and punishment occupied a large part of

62 Ibid., pp. 11-12, 51-52.

63 Ibid. 
the superintendent's attention, a reflection, no doubt, of official concern over the seemingly insolvable nature of these problems. Goree announced himself pleased with the state of discipline in the Huntsville unit. Punishment, when necessary, was inflicted strictly according to the regulations. He expressed less satisfaction, however, with disciplinary procedures in the outside forces, suspecting that a good bit of illegal or unauthorized punishment was meted out by guards with the knowledge of prison officials. Because of the illegal punishment, "several sergeants and a great number of guards" had been relieved of duty. Although Goree saw room for much improvement, he believed that conditions in the outside camps had become more tolerable over the last year. ${ }^{64}$

In response to the public criticism of using the prisoners in work forces outside the prison, an "opposition manifested. . . throughout the country," Superintendent Goree explained the necessity for such practices. He noted that instances of mistreatment of prisoners in the outside camps had been reduced considerably since the state had begun to demand that the lessees discharge their obligations to care for the prisoners. State cfficials inspected the canps regularly and removed officers when cases of abuse could be documented. State vigilance had $6 \stackrel{1}{ }$ Ibid., E. 13. 
caused instances of mistreatment to become the exception rather than the rule. The prisoners, according to the superintendent, were "well clad, well fed, and, as a rule, well treated." He did agree, however, with those who charged that the system left much to be desired.

No one will attempt to deny that the system is an evil, the true reason of which is because of the large mortality attending, the facilities afforded for escapes, and because under it there is little or no chance for reform. It can only be defended on two grounds: necessity, and because it is a source of revenue. 65

Goree believed that the "principal opposition" to the use of outside convict forces arose from the belief that such use of prisoners came into competition with free labor and, therefore, should be ended. He responded that if that were, in fact, true, "the same objection can be urged with equal if not greater force to the labor of convicts in the walls." No matter where, or in what manner, prisoners were worked, they would, to some degree, compete with free labor. Most everyone agreed, the superintendent continued, that prisoners shculd work and that the work done should be profitabie, "so that the conrict may earn the expenses attendant upon his incarceration." Therefore, the dilemma could be soived logically only iy placing the prisoners in the kind of work that would compete least with free workers. Goree argued that farm work was ideal, 
given "the great scarcity of farm labor" in Texas. He preferred to see the outside forces placed on large farms where better facilities could be built and more frequent inspection obtained. 66

The superintendent made additional recommendations designed to improve prison discipline. He requested that the legislature amend the commutation law to guarantee reenfranchisement for those prisoners who completed their sentence with no sustained charges of misconduct. He also recommended that any person sentenced to a term exceeding thirty years be eligible for release after serving the thirty years, provided there were no misconduct charges after the first five years of incarceration. Goree also commented on the continuing problem of hiring guards "of suitable material," and recommended that the state be responsible for hiring and paying all guards.

Guards are officers of the State, and their first allegiance is due the State; but employed and paid by someone else, they feel the greatest obligation to those who hold the purse strings.67

In keeping with the superintendent's suggestions, Governor Roberts, early in 1881, addressed a special session of the Seventeenth Legislature, a session necessitated in part by the need "to make further improvements and

$$
\begin{aligned}
& { }^{66} \text { Ibid., pp. } 21-24 . \\
& 67 \text { Ibid., pp. 14, 18-19. }
\end{aligned}
$$


regulations for the state penitentiaries.. . in anticipation of the expiration of the present lease,... On the first day of January, next year." Roberts commended the superintendent and the prison board for the hard work they had done in the area of improving prisoner care. He informed the lawmakers that the policy of his administration was to place "as many convicts as can be used to any profit" within the penitentiaries at Huntsville and Rusk. The remainder were to be put on large farms. 68

By working . . . the convicts in large bodies on farms, they can be taken care of better, and will be more healthy, there will be fewer escapes, and fewer of them will be wounded and killed in the effort to prevent escapes; they can be made equally as profitable to the State in that way; and a portion of them might be employed in the erection of another penitentiary in the western portion of the state. 69

Roberts sought from the legislature an appropriation large enough "to fit up the two.. . penitentiaries with new and improved machinery" to make them attractive to any potential lessee. He also wanted the state to commit itself as to the number of prisoners it would make available to work on the prison industries. The governor believed that only a total effort by the state could insure "that the experiment of such labor within the walls

${ }^{58}$ Governor's Messages, Coka to Ross: po. $387-388$, 395 .

$$
59 \text { ibid., p. } 396 .
$$


can be tested." 70

The legislature responded to the governor's remarks by passing a bill to bring about another reorganization of the prison administration. The lawmakers evidently were concerned, not only about the nature of any lease that might supercede the Cunningham and Ellis contract, but also that the Rusk penitentiary be organized properly and put on a sound administrative footing. To accomplish these objectives, the governor received much greater responsibility for determining prison policy. ${ }^{71}$ The new law abolished the board of directors and created a new penitentiary board. The new body would be composed of the governor, the state treasurer, and the prison superintendent and would have the ultimate responsibility for all prison matters, including the making and revoking of lease agreements, subject to the approval of the legislature. The penitentiary board received the authority to construct buildings, and to purchase land, equipment, tools, and other materials "to the end that the largest number of state convicts that can be profitably employed and comfortably accommodated, therein, may be confined and worked within the walls as soon as practicable. . . ."i2

$$
\begin{aligned}
& 70_{\text {Ibid., pp. } 395-396 .} \\
& 71_{\text {Gammel, Laws of Texas }}, 9: 130-142 . \\
& 72_{\text {Iidid., pp. } 130-232 .}
\end{aligned}
$$


The superintendent became the chief executive officer of the prison system. He was responsible for overseeing every aspect of penitentiary management and was to prepare monthly reports to the governor. The law also required the superintendent to visit each penitentiary at least once a month and each outside camp twice per year. ${ }^{73}$ The governor was to appoint an assistant superintendent to manage each penitentiary. The assistant superintendents would have full control and responsibility for their institutions. They would prepare monthly reports covering convict care, costs, and receipts for submission to the superintendent. 74

Two inspectors received the assignment to supervise the outside work camps. Each of the inspectors would be responsible for half the camps. The camps were to be visited at least once a month and a written report made to the superintendert. Inspectors would have the right to remove any officials under their supervision if charges of incompetence or mistreatment of prisoners could be sustained. 75

The provisions in the law regarding treatment of prisoners remained much as the existing laws already

$$
\begin{aligned}
& 73 \text { Ibid., pp. 132-133, } 139 . \\
& 74 \text { Ibid., pp. 134-135, } 139 . \\
& 75 \text { Ibid., pp. 155-136, } 139 .
\end{aligned}
$$


provided. Prisoners were not to be whipped except by written order of the superintendent, assistant superintendent, or inspector and all whipping was to be carefully supervised. There was to be no shaving of the prisoner's heads and no use of the stocks or "horse" under any circumstances. The commutation statutes remained in effect with only minor changes and the new law also left intact the provision for basic education for those inmates who needed it. 76

On April 14, 1881, the new penitentiary board met for the first time. It announced its principal raison d'etre to be that part of the reorganization bill which "requires that on the first day of January, 1882 or as soon thereafter as practicable," there should be confined within the walls of the penitentiaries "as many convicts as can be comfortable accommodated and profitably employed. . . " The board also denied a request by Cunningham and Ellis to extend their lease beyond the expiration date of Jaruary 1, 1883, as "impolitic . . for reasons not necessary to enumerate." 77

In late December, 1881, the lessees again asked the board for an early renewal of their lease. As an

${ }^{76}$ Ibid., pp. $: 38-\$ 39$.

77 "Minlutes of State Penitentiary Board from April 14, 1881 to Apri1 23, 1835," Penitentiary Papers, pp. 1-3. 
extra inducement, they offered to build a railraod east and west out of Huntsville to connect with major rail lines. The board again refused, however, saying such an agreement would be "impolitic and inconsistent with the best interests of the state. . . "78

The board never revealed the specific reasons for refusing to consider an extension of the Cunningham and Eilis lease. Presumably, board members believed they either could comply with the provisions of the 1881 reorganization, by having as many prisoners as possible in the walls by January 1, 1882, or they believed they could enter a lease agreement with other parties under terms more advantageous to the state. As the date for the termination of the Cunningham and Ellis lease drew nearer, however, the board discovered that the kind of arrangement it sought was not attractive to potential lessees.

On June 30,1882 , the penitentiary board made formal preparations to advertise for bids to lease the state prisons beginning January 1,1883 . Uppermost in the minds of the board members was their desire to place within the walls of both prisons as many inmates as could be comfortably housed and profitably employed. Furthermore, they wanted to see this done as soon as possible, "without the

$$
78 \text { Ibid., p. } 19 .
$$


imposition of a heavy tax upon the people of the state."79 In preparing the advertisements, board members decided not to seek another lease of the same type held by Cunningham and Ellis. They wanted, instead, to solicit bids for two separate and quite different contractual arrangements. Their decision to depart from customary practice in this instance resulted from the observation that under the previous leases of the prison, the lessees had neglected developing the industries inside the prison in favor of employing more and more prisoners at outside labor. According to the board,

Outside labor can be operated without any investment of capital, and is the most profitable. The policy of the State is to increase the inside force at the expense of the outside, while every effort of the lessee is to build up the outside, because it is to his interest to do so. 80

With this realization in mind, the board decided to seek separate bids for inside and outside labor. First of all, they wanted to make a lease for each penitentiary, Funtsville and Rusk. The lessees would have no interest whatsoever in any outside labor. The only way such leases could be profitable would be for the lessees to devote all their attention and effort toward successfully establishing the industries within the prisons. ${ }^{81}$

\footnotetext{
${ }^{73}$ Itid., p. 25.

80 Ibid.; Biernisl Recort, 1882, p. 7.

$81_{\text {Biennial Recort, }} 1332$, p. 7 .
} 
The board would also accept bids for prisoners to work on farms away, from the prisons. The outside labor would be contracted for directly from the state without going through a lessee. The board members agreed that preferential consideration would be given those bidders who desired to hire large numbers of prisoners, preferably in groups of at least sixty or more. By keeping the convicts in large groups they could be guarded more easily, would likely be better housed and fed, and could be watched over more carefully by the inspectors. 82

Having decided upon the kinds of bids it was willing to accept, the board placed advertisements in the Galveston Daily News, the Dallas Herald, the Austin Statesman, and the San Antonio Express. Additional notices appeared in the New York Sun, the Chicago Tribune, the Louisville Courier-Journal, and the St. Louis Republican. The ads ran for eight weeks in the Texas newspapers and for four weeks in those papers located out of state. Bids for the outside labor were received until August 15, 1882 and until September 15, 1882 for the lease of the prisons. 83

The board opened the bids for outside labor on

${ }^{82}$ Ibid., pp. 7-8; "Mirutes of Penitentiary Boarā," pp. 28-29.

83 "Minutes of Penitentiary Board," Penitentiary Papers, p. 27; Eiennial Report, 1882, pp. 7-8. 
August 15 and awarded contracts for a total of 1,040 prisoners. The contractors agreed to pay the state $\$ 15$ per month per prisoner hired. They further agreed to furnish housing for the convicts and to feed the prisoners and the guards. In return, they were entitled to ten hours labor per day from the prisoners. The state agreed to employ and pay guards and to take care of any "other expenses." Board members estimated that the expenses assumed by the state would total $\$ 9$ per month per convict, leaving a net profit of $\$ 6$ per month per man. 84

The state could not repeat the success in the attempt to lease the two prisons. On September 15, the penitentiary board met and discovered that no acceptable bids had been submitted. It then decided to extend the date for receiving bids until November 1,1882 and ran newspaper ads announcing the extension. On November 1 , there were, once again, no acceptable bids, so the date was extended to November 20 when the same results were obtained. Finally, on November 21, Cunningham and Ellis, along with General W. R. Hamby of Tennessee met with the boara and "were invited to make propositions for lease of [the] penitentiaries." 85

84 Biennial Report, 1882, p. 8.

85 Ibid.; "Minutes of Penitentiary Board," Peritentiary Papers, p. 41. 
Following the state's invitation, Cunningham and Ellis and General Hamby submitted proposals which the board found to be unacceptable. All parties than began lengthy negotiations that lasted just over one week. An agreement was ultimately reached in which the state leased the Huntsville penitentiary to Cunningham and Ellis and the Rusk penitentiary to General Hamby and his two associates Messrs. Cherry and Morrow, "two of the lessees of the Tennessee Penitentiary." 86

State officials believed the agreements reached with the lessees were "not bad. . . " The new contracts would not generate as much revenue as eariier agreements had, but "better provision is made for the security and comfort of the convicts. . . " In the end, the state agreed to accept a little less than it wanted from the lessees because the only other choice was to have the state operate the prisons. Apparently no one on the prison board thought that would work financially. 87

It has failed elsewhere, where there were better facilities for success, and would be apt to fail here. It would seem that the lease system is the only one left us. 88

\footnotetext{
86 "Minutes of Penitentiary Board," Penitentiary Papers, pp. $42-44$.

87 Biennial Report, 1882, p. 9 . $88_{\text {Ibid., p. } 10 .}$
} 
The prison board signed the new contracts leasing the prisons on December 18, 1882 and accepted the required bonds on January $11,1883 .^{89}$ The terms agreed to by the lessees differed somewhat from the earlier leases. Among the major provisions, the state agreed to lease each penitentiary for fifteen years and to assign one-half of the prisoners to each institution. The lessees agreed to "carry out in good faith" the contracts for farm labor that had been mace on August 15, 1882 and to pay all expenses associated with the prisons that the state would have had to pay had no leases been made. The lessees would have full use of all prison property, which they agreed to keep in good condition. The state would place 300 priscners in the Rusk penitentiary on January 1,1883 and increase the number annually so that by the end of the third year, a total of 800 persons would be incarcerated in the East Texas facility. Similarly, the Huntsville unit would house 400 prisoners as of January 1,1833 and the total would increase to 600 by the end of the third year. The iessees agreed to pay the state $\$ 10,000$ per year for each Eenitentiary. The state would employ anci pay all guards. Einaily, the state reserved the right to remove boys from the prison population if the legislature authorized the

89 "Minutes of Penitentiary Board," Penitentiary Eazers, tp. 44-45. 
establishment of a reformatory for juvenile offenders. 90 Shortly after the leases were signed, the new governor, John Ireland, presented them to the Eighteenth Legislature for ratification. The members of the prison board apparently believed legislative approval would be a mere formality. Events, however, proved them wrong. On February 18, 1883, Superintendent Goree appeared before a joint session of the House and senate penitentiary committees to review the leases and clarify the actions of the prison board in making them. He explained that his presence before the committees came as a result of criticism of the leases made "by some of the newspapers of the state, as well as by a few individuals." Goree defended the new contracts as being the best arrangement the state could make under the circumstances. 91

After detailing all the steps by the board to

90 Biennial Report, 1882 , p. 9; On November 10 , 1888, construction was completed on the first juvenile reformatory in the South, located on 696 acres near Gatesville, Coryell County, Texas. The young men sentenced to the reformatory worked on the juvenile farm but were not hired out to private parties. Governor's Messages, Coke to Ross, po. 632-634; Jane Zimmerman, "The Penal Reform Movement in the South during the Progressive Era, 1900-1917," Journal of Southern History 17 (November, 1951): 476-482.

91 Address of T. J. Goree, Superintencent of Penitentiaries, on the Penitentiary Leases, delivered before the Eenitentiary Committees of tire Senate and House of Represencatives, Eighteenth Legislature, in Joint Session, Eebruary 14, i883 (Austin: $E$. W. Swindells, State Princer, 1383), po. 3-14. 
obtain a satisfactory lease, the superintendent argued that the contracts for the two prisons would enable the state to recognize a profit while, at the same time, ensure that the majority of the prisoners would be housed within the prison walls at the end of three years. To those critics who charged that the terms of the final lease agreements differed substantially from those presented in the advertisements seeking bids, Goree pointed out that no one seemed to have wanted the prisons under the original terms of the state. With the end of the Cunningham and Ellis lease drawing near, the prison board had decided to alter its position and accept something less than it had sought initially, "rather than to have the state resume on the lst of January." 92

The superintendent admitted that the state would make less money from the lew leases than it had under the recently-expired contract, but explained that the demands piaced on the lessees under the agreements dictated that the state receive less cash in the immediate future in return for other long-term benefits. By agreeing to place the majority of the prisoners inside the prisons by the end of three years, the lessees had committed themselves, in the process, to the enormous cost of building up the prison industries. There would be eventually less of the

92 Ibia., pp. 3-4. 
profitable outside labor and more of the relatively less profitable inside work. In the end, however, the new agreements, if they worked as planned, would leave the state with firmly-established, economically-viable industries inside the prisons. Goree reminded the lawmakers that the law authorizing leases of the prisons did not require that the state derive "any large revenue" from them. There was a requirement, however, "that the [Prison] Board shall provide as soon as possible for the confinement of as many convicts within the walls as can be comfortably accommodated and profitably employed." 93

In early March, the state senate ratified the new leases by a vote of sixteen to fifteen. Those voting in the affirmative included ten members of the twelve-member penitentiary committee. Shortly after the senate vote, one source commented that Governor Ireland had lobbied actively for ratification of the lease and was chiefly responsible for the favcrable result. 94

When the bill reached the house, that body also seemed to be well on its way to granting approval. The penitentiary committee, on March 15, voted to ratify the

\section{Ibid. , pp. $4-6$.}

94 Journal of the Senate of Texas being the Regular Session of the leth Legislature begun and heid at the City of Austin, January 9, 1883 (Austin: E. W. Swindeli, State Printer, 1883), p. 6; The Daily Post (Houstor), March 8, 1883, F. I; March 18, 1883, D. 2 (Quoting the Marlin Bal1). 
lease. Eight members favored ratification, four opposed it, and one member abstained. Once again, Governor Ireland brought his influence to bear in favor of ratification. 95 Before the house as a whole voted, however, events came to light that embarrassed house members and caused many to reconsider the lease contracts.

In late March, Texas Siftings, an Austin newspaper, published articles in which it described attempts by the lessees to pressure the legislature into approving the leases. The charges made by the paper angered legislators who subsequently voted 85 to 7 to set up a special commission to investigate the allegations. The investigative findings indicated that the lessees had devoted considerable time and money to the task of winning friends among the lawmakers. 96

In the course of the investigation, a good many individuals were questioned. Although several refused to name names, all asserted that the lessees had indeed plied willing legislators with liquor and cigars. The iessees maintained private rooms in Austin and invited members of the legislature to partake of the free hospitality. One

\section{S5 The Daily Post (Houston), March 16, 1883, p. I;} March 18, 1383, p. 2 (Quoting the Sherman Colurier).

96 Ibid., March 31, 1883, p. I; Texas jiztings 2, No. 47, March j1, 1885, p. 6; No. 49, Aprii 14, I383, p. 8 . 
$\Gamma$

witness explained that because it was considered "vulgar and ungentlemanly" to give cash directly to the elected officials, legislators were allowed to win at poker.

The paper asserted that the Eighteentn Legislature would Lorever be known as "the poker Legislature." 97

Further indictments of the lessees came from two Austin saloonkeepers. These men revealed that since the legislature had convened, the lessees had spent in the neighborhood of $\$ 250$ to $\$ 400$ each in their saloons treating state legislators. The purpose of the generosity, of course, was to secure approval of the lease. 98

Texas Siftings charged additionally that the lessees' efforts had been most effective. The paper stated that fully nine-tenths of the people of Texas opposed the lease and that as a result, at the beginning of the legislative session, very few of the legislators had spoken in support of it. As the session wore on, however, and as more members succumbed to the blandishments of the lessees, support for the lease had increased. 99

It is impossible to know the impact of the information revealed in Texas siftings. Certainly the newspaper angered the legislature. Whether the legislators were

97 Texas Siftings, April 14, 1883, p. 8.

98 Ibid.

s9 Ibid. 
upset at the truth of the charges or were simply reacting to the fact that their honor had been impugned is unclear. From the furor that accompanied publication of the artiCles the lessees sensed that the leases were doomed.

On March 30, 1883, the lessees wrote Governor Ireland asking to surrender their lease. They stated that it had become apparent the legislature would refuse to ratify the contracts and that they, therefore, wished to be relieved of all responsibility regarding the prisons. One day later, the house voted 65 to 21 to revoke the leases. 100

The house vote in late March ended forever this type of leasing system in Texas. Never again would the state permit the control and management of its penitentiaries to pass into private hands. With the resumption of state control, prison officials faced the twin tasks of making the prisons self-sustairing financially while, at the same time, caring for the prison inmates in such a way that the abuses of the lease system could be either eliminated altogether or reduced to publicly acceptable levels.

The passing of the Cunningham and Ellis lease brought to an end a period of great prosperity for the prisor system. Luring the life of the lease the state.

100 The Daily Post (Houston:, March 31, 1893, ?. 1. 
had earned roughly $\$ 358,000$, in addition to the permanent improvements made to the prison facilities. The lessees themselves, according to one source, had made a "clear profit" of over $\$ 500,000.101$

Given the proven profitability of the Cunningham and Ellis lease, it becomes important to determine why the state chose to end it and, by so doing, deprive itself of a substantial source of revenue. By any economic measure, the spring of 1883 does not appear to have been a propitious time for the state to have embarked on a new course in penitentiary management. The prison population was continuing to grow, straining the available housing space. The industries in the Huntsville prison had not yet been established on a long-term self-sustaining basis and every indication seemed to suggest that large amounts of money would be needed to do so. The new Rusk prison faced an uncertain future. Yet the elected officials of the state, fully aware of the gravity of their decision, chose to revoke the leases and resume possession of the penitentiaries.

In taking such action, state legislators responded to a variety of public pressures. There is no way of measuring with any accuracy the true depth of the public hostility toward the lease. Nor is there any way to 
determine all of the reasons people opposed the system. But there is no denying that such feelings existed. Governor Roberts himself had acknowledged their presence and had spoken of his personal concern that the public feelings on this matter not be further aggravated. In the letters and petitions the governor received, as well as the findings of investigations conducted under his aegis, it had been demonstrated quite clearly that a growing percentage of people in Texas did not approve of the way the prisoners were treated by the lessees and resented the convicts taking jobs that law-abiding citizens should have.

Further evidence of the public anxiety regarding lease came from some of the legislators themselves. Representative J. Q. Chenoweth of Fannin County, while speaking in favor of ratification of the lease contracts in 1883, mentioned the great discussion and debate concerning lease that was taking place "throughout the entire state." Clay County Representative A. K. Swan, who also supported the lease, stated that he was doing so even though he recognized that "public sentiment is largely against the ratification of the lease. . ."i02

102 The Penitentiary Leases, Speeches delivered in the House favoring their Ratification bv Hon. I. Q. Chenoweth, Hon. H. J. Labatt, Hon. R. R. Hazlewood, Hon. A. K. Swan, Hon. W. F. Upton, and Hon. F. J. Chambers, $\frac{\text { Marsh, } 1883}{3,12}$ (Austin: Press of Deffenbaligh and Co., 1883), pp. 3, 12 . 
Some measure of opposition to leasing derived from the belief that the state could work its prisoners as the lessees had done and keep the profits. In essence, the state could eliminate the middle man, the lessees, and earn even greater revenues. Several members of the legislature admitted the existence of such opinions and further proof appeared in some of the newspapers around the state. The Sherman Courier, for example, argued that "If there are fortunes in it [lease] for the lessees, or at least 'big money,' why not the state derive the benefit?" A source in Marshall reported that the lease did not meet with the approval of local citizens, who felt "that a great wrong nas been inflicted upon the state in a pecuniary way. . ." One of the larger newspapers in the state, the Galveston Daily News, also supported state resumption of the penitentiaries and urged state leaders to appoint a "known Eirst-class businessman" to serve as financial agent of the prison system. The paper believed that "Properiy managed by competent men, the penitentiaries can be made to yield an immense revenue to the state. . . ."103 W:th such expressions of optimism, the state prison system thus entered the next phase of its devejopment.

$$
103 \text { Ibid., pp. 2-23; Tine Daily Post (Houston), }
$$
varch 15, 1333, p. 1; March İ, 1333, E. I; Galveston [äily News, $A p=i 1$ 11, 1883, p. 2 . 
The passing of the Cunningham and Ellis lease in a sense marked the end of an unfortunate era of the state's history. The financial distress and political turmoil that had led state officials to make the contract in 1878 had eased considerably. The lessees had improved substanTtially the permanent penitentiary facilities and structures. At the same time, they made money for themselves and for the state treasury. More importantly, their successful management of the prison had convinced the state that it could do the same and, in so doing, assert a greater measure of public responsibility for the care of state prisoners. 
CHAPTER IV

THE STATE AS LESSOR, 1883-1912

The legislative decision to terminate the leases with Cunningham and Ellis and with Morrow, Hamby and Company did not bring an end to leasing, as critics had hoped. Instead it marked the beginning of a thirty-year period during which the state attempted to emulate the Lormer lessees. The prison system continued to grow, in terms of inmate population as well as the acquisition of additional lands and permanent penitentiary structures. Thus, by the end of the first decade of the twentieth century, the foundation for the modern penal system in Texas had been iaid.

In many ways, the spring of 1883 was an economically propitious time for the state to bring its prisons under public control once again. The severe financial iistress of the late $1860 \mathrm{~s}$ and early $1870 \mathrm{~s}$ had been eased substantiaily by the sometimes extreme retrenchment policies of the Democratic governors, Ccike, Hubbard, and Poberis, who served during the $1870 \mathrm{~s}$ and early $1880 \mathrm{~s}$. Governor Roberts, the quintessential Texas Bourbon, embarkea on a orogram to rid the stata entirely of the 
long-standing debt by drastically cutting state expenditures beyond anything Coke and Hubbard had done, while at the same time selling off the public lands at fifty cents an acre to any and all purchasers. Roberts additionally committed state government to a "pay as you go" philosophy in public spending and saw it become an article of faith among his successors. 1

By the time Roberts left office in the spring of 1883, he had managed to retire a sizable portion of the indebtedness. In addition, he had renegotiated the remainder to reduce the annual interest payments to levels that could be managed with reserves from the general revenue fund. The Roberts policies, by lifting much of the burden on the state treasury, permitted state officials the luxury of flexibility in the management of state institutions, such as the prison. ${ }^{2}$

Most of the operating expenses for the penal system throughout the post-1883 period came from the labor of prisoners hired out to private individuals. The state acted as the hiring agent and derived the financial benefit that had previously gone to the lessees. State

${ }^{1}$ Miller, Einancial History of Texas, p. 240; Frank Edgar Nortor, "The Major Acministrative Folicies cf Oran Milo Roberts, "with an Introduction to his Life" (M.A. thesis, University of Texas, 1925), pp. 49-85.

Miller, Einancial History of Texas, pe. 229-239. 
officials, in both the executive and legislative branches, continued to act from the belief that the cost of operating the penitentiaries should come from the proceeds of the prisoners' labor and not from the taxpayers of the state. Unfortunately, and in spite of what appears to have been closer state supervision, abuses of prisoners in the outside work camps continued to be a major problem. Additional rules and regulations, plus the hiring of inspectors to enforce them, simply could not guarantee full protection against arbitrary and capricious conduct by guards. In the end, the treatment of prisoners in the outside camps figured prominently in the movement to end forever the practice of hiring out prisoners to private. individuals in Texas.

At the time the former lessees made known their intention of surrendering the lease, in 1883, Governor Ireiand sent a very pointed message to the legislature asking the membership to decide the action to be taken upon state resumption of control. Specifically, he wanted the state lawmakers to offer guidance to the prison board so that prison policies would be in complete conformity with legislative intentions and feelings. Ireland wanted to know, for example, if the decision to terminate the laases of Cunningham and Ellis, and Morrow, Hamby and Compary precluded any other leases from being made. Also, if the prischers were not to be leased, the governor 
desired to know what disposition to make of them. He noted that if the legislature sought to have all inmates within the walls of the prison at once, at least $\$ 500,000$ would be required to maintain them during the 1882-1884 biennium. If on the other hand, the legislature authorized the prison board to hire out the prisoners to private parties, it needed to indicate for whom the prisoners could work and the types of labor they could perform. 3

The governor further requested that the legislature consider removing the prison superintendent from the prison board. As chief executive officer of the institution and, concurrently, a member of the board, the superintendent found himself in the administratively anomalous position of having to pass judgment on his own job performance. Ireland believed the best interests of all concerned would be served mucin better by relieving the superintendent of all duties save those of running the prison. 4 Acting on the governor's requests, the legislature
reorganized the administrative structure of the state prison system. In a bill passed on April 18, 1883, the restructured prison board included the governor and two commissioners of peritentiaries who would be appointed by

3 Holiston Daily Fost, March $31,1883, \mathrm{p} .1$; Governor's Messages, Coke to Ross, p. 486 .

${ }^{4}$ Gorernor's Messages, Coke to Ross, p. 430 . 
the chief executive and approved by the senate. The new prison board would appoint an individual to serve as financial agent of the penitentiaries with ultimate responsibility for prison fiscal matters. ${ }^{5}$

The new law prohibited leasing the prisons and charged the prison board with the responsibility of confining all inmates within the walls of the penitentiaries "as soon as suitable prisons can be provided for their confinement and employment in such manner that they will be self-supporting." The board was authorized to employ the prisoners on state account, at contract labor, or both, depending on prevailing circumstances. Prisoners were not to be employed on public works projects other than building additional prisons, nor were they to perform any "mechanical labor outside of the walls, in any city or town." Should it become necessary, the board could purchase prison farms to work those convicts "not self-supporting" at other labors. 6

Shortly after passage of the prison reorganization

${ }^{5}$ Gammel, Laws of Texas, 9: 422-423. On March 31, 1385, the prison board was altered by the addition of a third commissioner to take the place of the governor, who removed himself from the day-to-day operation of prison a Ėairs. Since the contract system had functioned smoothly f::om its beginning in 1383, the chief executive did not need to give prison matters such close attention. Gammel, Laws oi Texas, 9: 707-708.

$$
{ }^{5} \text { Ibid., pp. } 422-423 \text {. }
$$


bill, Governor Ireland appointed I. G. Searcy and Walter Tips, both of Austin, to serve as the prison commissioners. The two men received no salary for their duties but were paid $\$ 5$ per day "while in attendance on the meetings of the board. . . ." The law specified that the commissioners would hold office for two years or "until the appointment and qualification of their successors." 7

As one of its first actions, the prison board drew up new rules and regulations to reflect the return to state management of the penitentiary. Many of the specific duties assigned to the various prison officers remained similar to the responsibilities listed in previous reorganizations. One significant exception, however, concerned the increase in authority given the officials to enforce the rules and regulations. The superintendent, assistant superintendents, and inspectors could dismiss any lower officers, such as sergeants and guards, who were found to be acting in riolation of prison procedures. 8

The iisting of specific duties and responsibilities for the financial agent were the most extensive, a reflection, verhaps, 0 E the importance of this position

'Ib:j.; Rules, Reculations an: By-Laws for the Government and jiscipline of the Texas state PenitenEisries, ar luntsvilie and Rusk, Texas (Austin: E. i. Swindells, Siate ?rinter, 1883), P. 54 .

Buies, Regulations and Bv-ia'ss, 1382, pF. 3-12. 
in the eyes of the board members. The financial agent was dubbed the principal "purchasing, selling and disbursing agent for the State Penitentiaries." He would receive all monies appropriated for penitentiary use and would supervise the purchase of all goods necessary to operate the facility. He would handle the payroll of all prison officials and, working with the superintendent, would make all contracts and receive all monies due the state from inmate labor or the sale of convict-made goods. Although the financial agent served under the superintendent, he reported directly to the prison board. 9

On April 20, 1883, the board considered the applications for financial agent. A total of four persons had expressed interest in the position. After reviewing the qualifications of each applicant, the board members, upon the recommenation of Commissioner Tips, unanimousiy selected Haywood Brahan, who had previously worked as "cashier and general business manager" for Cunningham and Ellis. According to Governor Ireland, Brahan's selection had come about because of his experience in prison

${ }^{9}$ Ibid., pp. 5-7. The position of Eirancial agent and the duties assigned to the individual who served in that capacity were not new in 1883. The criminal code adcoted by the state in 1858 had provided for a financial agent for the penitentiary. The position was done away with during the years tine prisors had been leased to private parties. Pascial, A Digest of the Law's of Texas, p. 405 . 
financial matters, an expertise badly needed by the state. 10 The board recognized very quickly that the two prisons could not accommodate all of the prisoners sentenced there. Hiring out some of them to private parties became a necessity. In considering this option, the state levied certain specific demanas of those wishing to work prison inmates. Among other requirements, private contractors sholild provide "a secure and commodious prison house" for the inmates. The building should be heated in winter and weil-ventilated in summer. There should be within the structure, at least two hundred and fifty cubic feet of living space for each prisoner as well as two and one-half feet of window ventilation for each occupant. There shoulc aiso be separate quarters for the detenticn and care of sick prisoners. 11

Contractors also had to provide all of the food for both prisoners and guards. Each inmate was to have a burk with bedding, as well as a cup, a plate, a soup pan,

\section{${ }^{10}$ Dalias Weekly Hera:d, April 25, 1883, p. 1:} "Minutes of State Denitentiary Board from April 14, 1881 to April 28, 1885," this is an unpubiishec journal housed with the Penitentiary Papers, Texas State Liorary and Archives, Austin, Texas, $=$. 59; Repcrts of the Superintendent and Firarcial igen = of the Texas State Penitentiaries, Embodving the procesdings of the state Penitentiary Board, ara Statistiza End Financial Exhibits; Also Reports of Suboráinare office 3 of the Texas State penitentiaries, Eor two years @ncing Detober 31,1884 (Austin: E. W. Swindel1s, state Prints: 1885i, p. 33 .

$$
\text { 11 Rules, Requiztichs end } 3 y \text {-ians. }: 883 \text {, pp. 35-36. }
$$


a knife, a fork, and a spoon. Prisoners clothes were to be washed weekly and the bedding "as often as necessary."12 On the matter of working conditions, the board stipulated that prisoners were not to leave their quarters to begin work until daylight and were to cease their labors in time to return to the prison house by dark. Contractors could not work the prisoners on Sunday or in inclement weather unless such work was "absolutely necessary to prevent great loss." In the event Sunday work became necessary, such as during sugar making, the prisoners were to be paid fifty cents per day by the contractor. ${ }^{13}$

In establishing the rules for hiring out the prison labor, the board recalled past problems in the outside camps and sought to lay down ground rules to prevent their recurrence. The outside forces, for example, were to be "consoiidated as much as practicable," and situated in areas "most accessible. . . by railroad." such placement would enable the inspectors to visit the camps regularly, thereby bringirg a greater measure of state supervision to the prisoners working away from the prison. In addition, as part of the effort to reduce the number of escapes, the board set the minimum number of prisoners to be sent to

\section{Ibid. Beginning in early 1898, the state began} feeding contract forzes. Biennial Report, 1898, ?. 7. 13 ibia. 
any outside camp at forty, with preference to be given to those persons wishing to hire even larger numbers. ${ }^{14}$

A further guarantee against potential trouble came in the dictum that only the sergeants of the outside camps were authorized to discipline the prisoners. Neither guards nor private contractors could inflict punishment for any reason or under any circumstance. The board restricted the types of punishment allowed at the contract camp to confinement in the dark cell not exceeding seven days at one time, confinement in irons, and use of the ball and chain, shackles, or spike on the ankle. It further allowed deprivation of privileges, forfeiture of commutation time, and whipping, "but only by special order, in writing, of [the] Superintendent, Assistant Superintendent or Inspector in particular cases."15

The rules and regulations drawn up in 1883 remained

14 Ibid., pp. 37-38. By congregating the prisoners in relatively large groups, the board seemed to think that the contractors and guarcs, cognizant of their responsibilities for such a sizable force, would go to greater lengths to design Eacilities and establish supervision procedures in such a way as $=0$ minimize opportunities for escape.

i5 Ibid., 0. 41. An amendment to the rules and regrlatiors adopted in 1893 establi of licks a prisoner coulc receive at one time at 39. Rules, Reculations and By-Iaws for the Government and Discipline of the Texas state Pen-tentiaries ard the Convicts belonging theretc at funtsvilie and Rusk and at Outside Camps (íustin: Ben C. Jones ard Company', Stace Printers; 1393$),$ p. 27. 
in effect, with minor changes, throughout the thirty-year period the prisons operated under the state contract system. Prison officials, anxious to prevent the mistakes and abuses of the past, sought to extend state supervision and control over every level of prisoner activity. The degree to which the new regulations were effective, however, depended, as in the past, on whether the individuals charged with enforcement performed their duties. Regrettably, the resumption of control of the penitentiaries by the state did not bring an end to the mistreatment of prisoners by private contractors seeking only personal gain.

As far as the individual prisoner was affected, the reorganization of the prison system and the promulgation of new ruies and regulations made little difference. The provisions designed to improve living and working conditions represented 1 it $\div$ le more than paper reforms, despite any good intentions that might have prompted them. In another sense, however, that of generating income, the overhauling of prison management policies ushered in a period of great prosperity for the state.

At the time the state resumed possession of its prisons, their value stood at slightly over $\$ 700,000$. All of the improvements made by Cunningham and Ellis at the Hur.tsvijls facility had increased its value Erom approximately $\$ 240,000$ to $\$ 450,000$. Monies expenced in the 
construction and equipping of the Rusk prison had totaled $\$ 276,356.50 .16$ The physical improvements notwithstanding, however, the two institutions remained a drain on state revenues. Prison officials thus faced the immediate necessity of taking steps to establish the industries inside the prisons so that as soon as possible they would yield a profit. 17

On May 5, 1883, the prison board authorized the publication of advertisements seeking bids to operate the prison shops. The announcements appeared daily for two weeks in the Galveston News, the San Antonio Express, the Dallas Herala, the Louisville Courier Journal, the New York Sun, the Nashville American, and the St. Louis Republican. Bids were received until July $16,1883.18$

A total of five firms resporded to the state's offer. After a great deal of negotiation, bordering at times on haggling, the prison board entered into agreements with three of the companies. The Wiggin-Simpson Company contracted for "machine and boiler shops and foundry" in the Huntsville unit. Also at Huntsville, the Eirm of H. C. Still and Brother used inmate labor to manufacture

\footnotetext{
${ }^{16}$ Biennial Report, 1882, pp. $4,15$.

17 Biennial keport, 1884, pp. 7, 16 .

18 "Minutes of the Penitentiary Board," Fenitentiary Papers, p. 70 .
} 
"saddle-trees, stirrups, and girths. . . ." The most substantial of the three agreements went to the firm of comer and Fairris which received 1,000 prisoners to operate the various parts of the iron industry at the Rusk prison. 19 The state would have preferred to see a larger response to its offer for outside contractors to work the convicts within the prison. Quite obviously, the greater the variety of industry pursued within the prisons, the greater likelihood of financial profit for the state. Moreover, healthy, profitable industries within the prisons would enable prison officials to place larger numbers of convicts within the walls. An "exceedingly anxious" Superintendent Goree hoped to see the three contractors succeed "because their success may induce others to contract for labor and shops." 20

Unfortunately, Goree did not realize his expectations. None of the contracts worked out as planned and within a very few years, the state was forced to cancel the agreements and operate the industries on the state account system. 21 The reasons surrounding the failure of

19 Biennial Report, 1884, pp. 8-11. ${ }^{20}$ Ibid., F. 8 .

21 Repcrts of the Superirtendent and Financial Agent of the Texas State Penitentiäies. Embodying the Eroceedings of the Penitentiar Bcard, a:d Staristizal ane Financial Exhibits; Aiso Feports CI Suborcinate Cficicers Jf the 
the three private firms merit examining at some depth for the information they reveal concerning the difficulties of establishing prison industries and the state's handing of the problems.

The contracts with Wiggin-Simpson and H. C. Still and Brother failed primarily because of undercapitalization of the two firms coupled with a general "stagnation of business" which set in shortly after the agreements were signed. Wiggon-Simpson had received seventy-five convicts for which they paid the state sixty cents per day per man. The company evidently made a good faith effort in behalf of its contract, but by January, 1885, found itself unable to make the monthly fayments to the state. The company asked for and received an extension on its labor payment, but by early summer its financial situation had not improved measurably. So on June 10, 1885, the Wiggin-Simpson Company surrendered its contract and ceased operations in the prison. 22

Texas State Penitentiaries for Two Years, ending October 31,1888 (Austin: Eugene von Boeckmann, State Printer, 1889), p. 12 .

22

Biennial Report, 1884, . 2 ; Reports of the Superintendent and Firancial Agent of the Texas state Penicentiaries, Embcdying the Proceedings of the Penitentiary Board, and statistical and Financial Exhibits; Also Reforts of Subordinate Ojficers of the Texas State Penitentiaries, for Two Years, ending Cctober 3i, 1886 iAustin: Triplet: and Hutchinos, State Printers, 1386), pp. 10-11, 71-72. The official reports on the demise of the Wigginsimpson contract are somewhat confusing in the chrorology 
H. C. Still and Brother originally had contracted for a total of thirty-five prisoners, twenty-five at sixty cents per day and ten at fifty cents per day. This company fell victim to the same difficulties that had plaqued Wiggin-Simpson but found itself able to hold on a little longer. It received several extensions from the prison board on labor payments, but by late May, 1887, it too had exhausted all sources of financial assistance and terminated its contract with the state. 23 Following the collapse of the two firms operating in the Huntsville prison, the board decided to hire outside managers and operate the prison shops on state account. 24

The problems which beset the private contractors in the Huntsville prison also visited the shops run by the state. Prison officials reposed much hope in the manufacture of farm wagons, an enterprise which no private contractor could be persuaded to undertake. The state,

of the company's financial problems. In one part of the 1886 biennial report, both the superintendent and financial agent mention that the contract ended on June 10, 1885. In another part of the report, however, the financiel agent states that the company did not begin to experience financial difficulities until December, 1885, several months after it had terminated its contractual agreement with the prison system. Ore assumes the financial agent to have been in error in his subsequent remarks.

$23_{\text {Bienniai Report }}, 1884$, p. 8: Biennial Report, 1886, pp. 10, 72-73.

24 Biennial Repo:t, 1384, p. 8; Biennial Report, 1888 , pp. 10-12. 
as early as 1888, discovered that the preferred wood for the construction of wagons (white oak) could not be found in sufficient quantity or quality in Texas, the nearest supply point being st. Louis. The cost of shipping the raw wood to Texas, plus the time lost as the wood seasoned fifteen to twenty-four months, caused considerable lag time before a finished wagon could be shipped to retailers. Hefty appropriations from the legislature were needed to make the initial purchase of the timber, and additional monies were required to operate and maintain the wagon shop until the wood matured and fabrication could begin. 25 Once the wagons were completed and offered for sale, additional problems arose. Some potential customers refused to buy the wagons, charging they had been built by unskilled prisoners. Other wagon manufacturers, in an eficrt to sell their products, exploited the fact that the prison wagons were convict-made, thus appealing to those persons who believed that convict-made goods represented work taken from Eree citizens. All of the problems tempted prison officials to abandon altogether the manufacture of wagons. Such a course was not taken, however, as the work kept a certain number of prisoners busy and made use of expensive machinery that was suited only for

\section{Biennia: Report, i\&84, pp. $\$ 3-45$; Biennial}

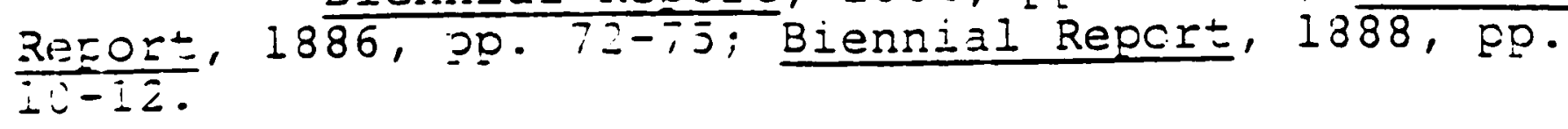


the wagon industry. 26

The general failure of the Huntsville industries was duplicated, if not exceeded, at the East Texas penitentiary in Rusk. The legislature appropriated enormous sums of money to exploit and develop an iron industry from the abundant ore supplies in the northeastern portion of the state. Yet mismanagement and administrative neglect, in conjunction with all the usual economic vagaries eventually induced state officials to cease their efforts. 27

The Rusk prison became operational in the spring of 1883, coinciding with the end of the Cunningham and Ellis lease. In July, Comer and Fairris made their contract with the prison board and officially took over the management of the facility on January 1, 1884. Almost from the beginning serious disputes arose between prison officials and the contractors. 28

The agreement drawn up between the state and Comer-Fairris stipulated that the contractors were to receive 1,000 prisoners who would be divided into three

26 Biennial Report, 1888 , pp. 10-12.

27 For an account of the financial difficulties at the Rusk prison see Billy Martin Birmingham, "An Historical Account of the East Texas Priscn at Rusk" (M.A. thesis, the Instituce of Contempcrary Corrections and the Behavioral Sciences at Sam Houston State University, Huntsville, Texas, Maj, 1979).

28 Biennia: Report, 1884 , pp. 10-11. 
classes. No mention was made as to the criteria for classification, but the agreement did specify that the state was to receive $\$ 100$ per year for each first class prisoner, $\$ 75$ per year for second class inmates, and $\$ 50$ per year for those designated as third class. ${ }^{29}$ Given the different types of work that would be needed to develop the iron industry at Rusk (miners, furnace operators, machinists, and so forth), it seems reasonable to surmise that the prisoner classification system was based on relative skill levels of the inmates.

The contract sought to have as many of the 1,000 prisoners as possible at work inside the prison and specifically enjoined Comer and Fairris from working inmates outside the penitentiary except for "such number . . as might be necessary to cut wood, dig ore, burn coal, get lime rock, saw lumber and make provisions and forage for the necessary operation of the furnace ard penitentiary." Before the agreement was signed, prison officials estimated that about three hundred prisoners could take care of all the outside work. Superintendent Goree insisted that the contractors limit the number of inmates working cutside, since the state paid the guarcis, and the larger the number of prisoners outsice the prison the greater tre size of the force necessary to guard them. 30

$$
29 \text { Ibid. } \quad 30_{\text {Ibid., p. } 11 .}
$$


One of the first disagreements between the state and Comer-Fairris resulted over the interpretation of the outside work "to make provisions and forage" to support the prison. The contractors interpreted this clause to mean that they had "the right" to use as many prisoners as they wanted to raise cotton, presumably to sell at a profit. When the superintendent, backed by the prison board, refused to permit such use to be made of the prisoners, the contractors asked that their contract be modified so that they would receive and be responsible for only 500 inmates. 31

The size of the work force Comer and Fairris had expected to use raising cotton, 500 men, leads one to suspect that their interest in making iron was dilatory at best. Had they been allowed to proceed with their original plan, cotton very likely would have become their major source of income, at least in the short term, and would have received most of their attention and effort. Members of the prison board must have questioned the degree of commitment on the part of the contractors to carry out in good faith the primary objective of developing the East Texas industry. In spite of the obvious anxieties they must have felt, prison board members approved the reduciion in the Rusk work force as requested. 
Other problems would not be solved so easily.

The original furnace installed at Rusk had a twenty-five ton production capacity. ${ }^{32}$ It went into blast in the latter part of February, 1884, but failed to perform up to expectations. Instead of producing twenty-five to thirty tons of iron per day as expected, it brought forth only eight to ten tons, much of which was of substandard quality. The poor performance was attributed to faulty design problems. Thus after two months of operation, "it was blown out" and the necessary structural changes made. ${ }^{33}$ The modified furnace went back into blast in early June and production increased although at levels still below those originally anticipated. This, along with other problems, led prison officials to bank the fires once again in early september. Within a few days of the second shutdown, Comer and Fairris contacted the prison board and surrendered their contract. 34

The problems encountered by Wiggin-Simpson and H. C. Still and Brother at Huntsville also seem to have plagued the Rusk contractors. Comer and Fairris faced insurmountable difficulties in marketing their products and had to delay labor payments to the state. The prison

\footnotetext{
32 Biennial Report, 1882 , p. 5.

33 Biennial Report, 1884, p. 12.

${ }^{34}$ Ibid., pp. 12-13.
} 
board demonstrated a willingness to work with them through the difficult early months of operation, but by early September the contractors themselves sought to be relieved of their responsibilities and obligations toward the prison system and to settle with the state. 35

The initial setbacks in establishing the iron industry at Rusk did not deter superintendent Goree from his belief in the ultimate success of the venture. He suggested that the poor production and other problems that had attended the first few months of the furnace operation had emanated from a lack of leadership and business skill on the part of the contractors.

The furnace plant is a good one as originally constructed; the iron ore is convenient, abundant and of fine quality, there is plenty of good wood accessible for charcoal. Lime rock is inconvenient, and transportations for it high, but it can be procured, and in my opinion the only thing that is needed to make good iron, and a plenty of it, is good management. 36

Goree went on to recommend that a professional furnace operator be hired and the iron industry at Rusk be developed on the state account system. He envisioned using the iron to make railroad car wheels, stoves, plows, water pipe and hollow ware, all of which could find a ready market in Texas, adjoining states, and Mexico. Operation of the furnace alone would require the labor

$$
{ }^{35} \text { Ibid. } \quad{ }^{36} \text { Ibid., p. } 13 .
$$


of two hundred and fifty prisoners and more could be brought into the walls as the ancillary industries developed. 37

The Nineteenth Legislature appropriated $\$ 50,000$ to establish the Rusk iron industry on state account. As the first order of business, a Philadelphia consultant and expert in the making of iron, John Birkenbine, traveled to Texas to examine the operation at Rusk and make suitable suggestions and recommendations to state officials. Birkenbine, evidently quite impressed with what he found, stated that the prospects of an iron industry at Rusk were comparable to if not better than most places in the country. 38

The state acted quickly following the submission of the consultant's report. R. A. Barrett, the St. Louis furnace expert who had supervised the initial construction of the Rusk furnace, agreed to serve as furnace superintendent. Under Barrett's management, furnace production rose sharply; "the output was seldom less than 25 tons per day, and frequently over 30 tons per day." By November, 1886, the furnace, under Barrett's supervision, had been in blast slightly over six months. Production for this period totalled 4,113 tons of iron, which was worth approximately $\$ 65,808 .^{39}$

\footnotetext{
37 Ibid., pp. 13-14. ${ }^{38}$ Biennial Report, 1886, ․ 12. ${ }^{39}$ Ibid., pp. 12-13.
} 
At about the time that the prison board had decided to hire professional managers to operate Rusk on state account, a fortuitous opportunity to stimulate iron production presented itself. Shortly after the capitol building in Austin burned in November, 1881, the state decided to proceed with the construction of a new state capitol. The contract for erecting the new building went to an Illinois firm that agreed to accept 3,000,000 acres of the public land as payment for the construction. The prison board moved quickly to provide the cast iron work for the building. Specifically, state prisoners would fabricate the "columns, with their pedestals, bases and caps, and the castings for the dome of the building." It was estimated that some 2,000,000 pounds of cast iron would be needed, thereby netting the Rusk prison approximately $\$ 67,500$. In addition to the money to be earned, prison officials believed the contract to be a good one as it would provide for the consumption of the furnace products, keep a relatively large number of prisoners at work within the walls of the Rusk facility, enable "a large number of convicts" to be trained as moulders, and display the products of the Rusk furnace for all to see. 40

40 Ibid., p. 14. Ruth Allen, Chapters in the History of Organized Labor in Texas, The University of Texas Publication No. 4143 (Austin: Bureau of Research in the Social Sciences, November 15, 1941), po. 45-88; Records of the Capitol Building Commission, p. 1, Texas state Library and Archives, Austin, Texas. 
The original plans for the building called for a "superstructure of limestone upon a base of two courses of granite." When the cost of importing the limestone from outside the state proved to be prohibitively high, however, a decision was made to use red granite from quarries in Burnet, Texas for the outer walls. A relatively smaller amount of limestone available from quarries near Oatmanville, Texas would be used for the inner walls. 41

The decision to use local granite rather than limestone as the principal construction material prompted Governor Ireland to recommend the use of state prisoners to quarry the stone. Prison inmates also could build a railroad needed to move the granite from the quarry in Burnet to Austin. The prison board, in July, 1885, adopted the governor's recommendations and made available to the capitol contractors approximately 500 prisoners. The terms of the agreement stipulated that the state provide guards, housing, and food for the inmates in return for a labor charge of sixty-five cents per day for each prison worker. ${ }^{42}$ The contracts for quarrying stone also proved to be profitable for the state. The prisoners at Oatmanville completed their work on May 1, 1887 and earned a clear

41 Allen, Chapters in History of Organized Labor in Texas, pp. 45-46; Biennial Report, 1888, p. 69.

42 Biennial Report, 1886 , pp. 19-20; Governor's Messages, Coke to Ross, . 536. 
profit for the state of $\$ 1,720.64$. The force at Burnet finished its work one month later and yielded a profit of $\$ 5,178.08$. The state thus earned a total of $\$ 6,898.72$ over and above all costs to maintain the prisoners. 43

The use of prison labor in conjunction with the construction of the new capitol seems to have pleased legislators and prison board members whose responsibility it was to keep the prisoners at remunerative employment. These same people, no doubt, would have been satisfied had the earnings from the inmate labor only covered expenses. That a profit was recognized as well simply made the effort that much better.

The enthusiasm of state officials, however, was not shared universally. The decision to use prison inmates to quarry the stone for the capitol building aroused the ire of the Granite Cutter's National Union, which discouraged its members from working on the job and training the prisoners. The union argued that if a few journeymen granite cutters trained convicts, those convicts, in turn, would train others and soon there would be no need for the higher-salaried free granite cutzers. 44

The call for a boycott of the capitol job proved

43 Biennial Report, 1888, p. 69 and Exhibit F., 2. 8:

44 Allen, Chapters in History of Organized Labor in Texas, pp. 46-48. 
so successful that the contractors had to import granite cutters from Scotland to supervise the work. This prompted a lawsuit filed in Austin against the contractors for violation of an 1885 federal law which prohibited the importation of foreigners under contract to perform labor in the United States. After considerable delay and legal maneuvering, the case came to trial in August, 1889 and the contractors were found guilty. The were held liable for fines and court costs totalling $\$ 65,000$ but after the granting of executive clemency by President Harrison, the amount was reduced to $\$ 9,000 .^{45}$ The enthusiasm the granite cutters demonstrated in their opposition to the use of prison labor and the national notoriety focused on the Texas case explain, at least in part, the lengthy discourse by state prison officials on the rationale for working prisoners and the proper disposition to be made of convict labor.

Superintendent Goree noted that the issue had aroused considerable feeling in Texas as well as the rest of the nation and was "the most difficult of solution of any pertaining to political economy." All the efforts made to devise a compromise acceptable to the greatest majority had failed; "the question of what to do with

${ }^{45}$ Ibid., pp. $48-53$. 
convicts is further from solution than ever." 46

Goree believed "that the working of convicts outside the walls is an evil, because of the mortality and escapes attendant on the system." He noted additionally, however, that existing state law provided that convicts only be kept within the walls if they could be employed "in such manner that they will be self supporting."

However much any penitentiary management may desire to work convicts within the walls, they have to be governed by the requirements of the law while in force. 47

The population of the Texas prison system late in 1886, when Goree made his remarks, stood at "nearly 3,000." Cell capacity of the Huntsville and Rusk prisons was only 1,600. According to the superintendent, "even now if we were to fill the prisons to their full capacity, it would be impossible to find employment to render them self supporting." Furthermore, there existed, according to Goree, "a very large class of convicts in Texas. . who are totally unfit for skilled labor, and cannot be profitably employed in the walls. . . "48

The only way to solve the problem, Goree believed, would be to recognize that the different types of prisoners 1888 , p. 24 .

46 Biennial Report, 1886, p. 22; Biennial Report,

$$
47 \text { Biennial Report, } 1886, \text {. . } 23 .
$$


required different types of work to keep them busy and earning their keep. Provide the necessary work, the superintendent argued, and be prepared to deflect as well as possible the inevitable criticism.

The true policy would seem to be to confine as many convicts as can possible be made self sustaining within the walls, and to provide additional prisons and equip them for as many of that class as can be so made self sustaining. Those convicts who cannot possibly be made self sustaining in the walls should be worked at some remunerative employment on the outside, either on state account or otherwise, as may be deemed best. Let them be placed at such labor as is least detrimental to health, where they can be most securely kept, and where they are least likely to antagonize, or come in real competition with free labor. 49

Ideally, Goree's suggestions would seem to have been the least objectionable way to deal with a most difficult problem. By placing the prisoners at the kind of work for which they were best suited, they would have been productive and the income from the labor would have gone to help maintain the prisons. Unfortunately, as the system evolved over the years, the balance the superintendent had envisioned did not develop. The industries inside the two prisons, even though they languished amidst a number of difficulties, continued to provide jobs for some inmates. The outside forces, on the other hand, flourished and paid handsome dividends. Inevitably, the profits from hiring the prisoners to work outside the prisons led 
to larger and larger numbers being employed in such manner. For well over a year following resumption of control, the prison board made contracts with outside parties seeking to hire state prisoners. By November, 1884, a total of 1,148 inmates worked for private individuals on farms scattered through the southern and eastern parts of the state. In addition, 176 state prisoners worked on construction crews for four railroads, the Galveston, Houston and San Antonio; the Houston and Texas Central; the International and Great Northern; and the Texas Central. 50

Over the years, the railroad contracts proved to be more lucrative per man employed than did the farm labor. In 1884, for example, the state received $\$ 1.25$ per man per day for those inmates working for the railroads. The price declined a few cents during the hard economic times of the mid-1880's and remained at only slightly over $\$ 1.00$ until the early years of the twentieth century when it climbed, once again, to $\$ 1.15$ per cay. 51

In areas other than the relative profitability,

50 Biennial Report, 1884, p. 29; Biennial Report, 1888, p. 19.

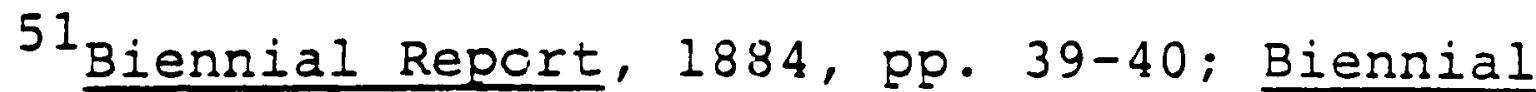
Report, 1886, p. 67; Biennial Report of the Commissioners, Superintendent, Financial Agent and Subordinate Officers of the Texas State Penitentiaries for the Fiscal Years Ending August 31, 1907, and August 31, 1908 (Austin: Von Boeckmann-Jones, Co., Printers, 1908), p. I0. 
however, the railroad forces proved to be less attractive. The railroads never made use of more than a small minority of the total convict population. During the year 1892, for example, the various railroads employed the largest number of state prisoners, 588, of any year in which prisoners were put to such use. Yet the total convict population that year stood at 3,575, leaving some 2,987 prisoners who had to be placed elsewhere. 52

Another drawback to the large-scale placement of convicts at work for the railroads lay in the tenuous nature of the contractual arrangements the state was able to obtain from the companies. The railroads refused to obligate themselves for extended periods of time. They hired the prison labor with the understanding that they reserved to themselves "the right of returning it at any time on short notice." Prison officials had to face the fact that at the first sign of economic troubles, the railroads could return the prisoners to the penitentiaries, thereby placing extra demands on the state's resources. Superintendent Goree admitted openly in 1890 that were

52 Reports of the Superintendent and Financial Agent of the Texas State Penitentiaries, For Two Years Ending Cctober 31, 1892 (Austin: Ben C. Jones and Co., State Printers, 1892), p. 29. The figures given represent totals during the state contract period only, 18831912. The year in which the largest number of state prisoners worked for the railroads was 1882, during the Cunningham and Ellis lease. Biennial Report, 1882, pp. $36-37$. 
the railroads suddenly to return the convicts then under contract, the prison system would be unable to house the men or find anything for them to do. 53

The outside farm labor, while it yielded less earnings per individual prisoner, provided greater stability than railroad work. State officials could be reasonably certain that farm forces would be kept in place for the life of the contract. On those few occasions when private farm contractors realized they could not honor their agreements with the state, prison officials encountered few difficulties in either negotiating a new contract or placing the prisoners on other farms. Throughout the - Fentire period of state contract management, outside farm labor brought in the largest amount of revenue. 54

53 Reports of the Superintendent and Financial Agent of the Texas State Penitentiaries Embodying the Proceedings of the Penitentiary Board, and statistical and Financial Exhibits; Also Reports of Subordinate Officers of the Texas state Penitentiaries, for Two Years Ending October 31, 1890 (Austin: Henry Hutchings, State Printer, 1890), p. 115.

${ }^{54}$ For the period May 16, 1883 to August 31,1908 , official reports of the prison system show a net profit of $\$ 3,423,087.63$ earned from the farm labor. See Biennial Report, 1884, pp. 60-61; Biennial Report, 1886 , pp. 91-92; Biennial Report, 1888, pp. 7-9 in Exhibits Section; Biennial Report, 1890, pp. 128-132; Biennial Report, 189 2 , pp. 105-109; Biennial Report, 1894, pp. 92-95; Biennial Report, 1896, pp. 95-98; Biennial Report, 1898, pp. 89-92; Biennial Report, 1900, pp. 100-101; Biennial Report, 1902 , pp. 120124; Biennial Report, 1904 , pp. 133-136; Biennial Report, 1906 , Pp. 103-105; Biennial Report, 1908, Pp. 109-110. 
The profitability of prisoners working on private farms represented only one of the attractions for the state. Such arrangements also provided a virtually limitless means of placing individuals for whom there was no space in the prisons. Also, prison officials discovered that a large percentage of prisoners possessed no formal skills or trades so that farm work became the one type of employment in which such persons could be made productive. Superintendent Goree recognized quite clearly the value of farm labor for certain prisoners. He noted that a "large majority" of the prison population in Texas had been raised either on farms or on the prairies "branding 'mavericks'. . . " Such persons had no marketable industrial skills and, if placed at labor inside the prison, "would be a clog upon good discipline, and. . would be a constant strain upon the industry of the competent convicts." According to Goree,

The only plan to pursue with this class of convicts, white and colored, will be to place them at suitable labor on the outside, which I think should be farm labor. 55

Goree's opinions and suggestions, which he expressed on several occasions, evidently made an impression on the prison board and the elected leaders of the state. Every year between 1884 and 1910, at least 1,000 prisoners

55 Biennial Report, 1880, p. 23. 
worked on outside farms. For the first nine years following resumption, the number hovered at the 1,000 mark. Between 1892 and 1894, however, during the administration of Governor Hogg, it surged dramatically from 1,039 to 1,739. It increased to over 2,000 by 1896 and reached its peak, 2,363, in 1902. From that point, the number began a steady decline until, by 1910 , it had reached $1,692.56$

As the numbers of prisoners on the farms increased, so did the price of their labor. The low price of $\$ 15.00$ per month was charged those contractors who received prisoners in the fall of 1882 and renewed their contracts in 1887. By 1892, the state had structured the labor price according to the type of crop raised. Seemingly, the more valuable the crop, the higher the labor charge. Those prisoners, for example, working on farms where sugar was the exclusive crop brought the state $\$ 17.00$ per month per man. The amount of $\$ 16.50$ per month was charged those planters who raised both sugar and cotton, and the lowest charge, $\$ 15.50$ per month, was levied against those farmers who raised

56 Biennial Report, 1884, p. 18 ; Biennial Report, 1886 , p. 9; Biennial Report, 1888, p. 28, Exhibit 9; Biennial Report, 1890, p. 56; Biennial Report, 1892, p. 29; Biennial Report, 1894, p. 32; Biennial Report, 1896, p. 39; Biennial Report, 1898, p. 29; Biennial Report, 1900, p. 29; Bienniai Report, 1902 , p. 38; Biennial Report, 1904, p. 38; Biennial Report, 1906 , p. 27-28; Biennial Report, 1908, p. 31; Biennial Report, 1910, p. 35. 
cotton and corn. 57

Labor charges dropped slightly during 1894 and

1896, but by 1898, prices were on the rise once again. There appeared also in 1898 an additional classification of the workers, this time into first and second class hands. The labor charge for first class hands on farms raising both cotton and sugar was $\$ 19.50$ per month per prisoners. First class hands on farms where cotton alone was grown brought $\$ 18.00$ per month and second class workers brought $\$ 16.50$ per month. 58 presumably, the separation of the prisoners into first and second class categories had to do with their physical abilities to perform labor wherein age, and general health would figure prominently. ГBy 1904, the state could command $\$ 21$ per month for

${ }^{57}$ Biennial Report, 1882, p. 8 ; Biennial Report, 1888 , p. $19 ;$ Biennial Report, 1892 , p. 9 .

58 Reports of the Superintendent and Financial Agent of the Texas State Penitentiaries Embodying the Proceedings of the Penitentiary Board, and Statistical and Financial Exhibits; Also Reports of Subordinate Officers of the Texas state Penitentiaries. For Two Years Ending October 31, 1894 (Austin: Ben C. Jones and Co., State Printers, 1894), p. 11; Reports of the Superintendent and Financial Agent of the Texas State Denitentiaries Embodying Statistical and Financial Exhibits; Also Reports of Subordinate Officers of the Texas State Penitentiaries. For Two Years Ending October 31, 1896 (Austin: Ben C. Jones and Co., State Printers, 1896), pp. 10-1I; Reports of the Superintendent and Financial Agent of the Texas State Penitentiaries Embodying Statistical and Financial Exhibits; Also Reports of Subordinate Officers of the Texas State Penitentiaries for Two Years Ending October 31, 1898 (Austin: Von Boeckmann, Moore and Schutze, State Contractors, 1898), p. 12 . 
for first class hands and $\$ 18$ per month for workers of the second class. 59 Sometime during the period 1904 to 1906 a decision was made to hire out only first class hands to the private contractors for $\$ 21$ per month. 60 This price was short-lived for by 1908 labor costs for state prisoners to work farms had reached their highest point, $\$ 31$ per month for first class black prisoners and $\$ 29$ per month for first class white prisoners. ${ }^{61}$ This price continued until the contract system ended in 1912 .

The rather rapid increase in the cost of prison

59 Biennial Report of the Superintendent of Texas State Penitentiaries. For twenty-four Months Ending August 31, 1904 (Austin: State Printing Company, 1904), p. 15.

60 Biennial Report of the Commissioners, Superintendent, Financial Agent and Subordinate Officers of the Texas State Penitentiaries for the Fiscal Year Ending August 31, A.D. 1906 (Austin: Von Boeckmann-Jones Co., Printers, 1906), p. 11 .

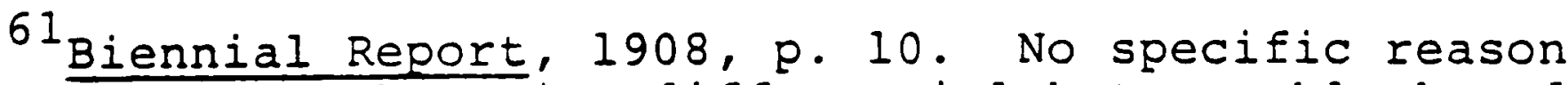
could be found for the price differential between black and white prisoners. Very likely, the higher charge for black labor stemmed from the fact that black prisoners were used almost exclusively on the sugar farms, where labor charges traditionally had been greater. As well as could be determined, the prices charges for prison labor, especially during the early years of the twentieth century, were only slightly less than the wages of free workers similarly employed. The obvious advantage to hiring prison inmates lay in the fact that the state guaranteed a work force of a determined size, kept the prisoners at their assigned tasks, and freed the contractors of any responsibility for involving themselves in labor matters. John stricklin spratt, The Road to Spindletop. Economic Change in Texas, 1875-1901 (Austin: University of Texas Press, 1970), Pp. 229-231. 
labor during the late $1890 \mathrm{~s}$ and the first decade of the twentieth century appears to have been little more than an attempt by the state to earn as much revenue as possible from its prisoners. Texas farms remained essentially without mechanized equipment during this time, so state officials could feel free to raise the price of the prison labor with little fear that the private contractors, almost wholly dependent on human and animal labor, would look elsewhere for workers. It was not until the 1930 s that agricultural mechanization began to become commonplace on Texas farms, thereby displacing the more traditional forms of labor. 62

In addition to hiring out prisoners to railroads and private farmers, the state agreed to furnish a limited number of prisoners for more specialized kinds of work. In 1906, 49 state prisoners mined coal for the Consumers Lignite Company in Alba, Wood County, Texas. The contractors paid $\$ 35$ per month for each of the prisoners. 63

${ }^{62}$ Farm mechanization did not begin to arrive in Texas until the prosperity of the World War I years increased significantly the income of the state's farmers. Low prices for agricultural products during the late $1920 \mathrm{~s}$ blunted the trend somewhat, but by the 1930s, the replacement of human and animal labor with machines made substantial progress. The most extensive use of machinery occured in the Panhandle and along the coastal areas of the state, with relatively less in central and east Texas and inland on "the river bottom plantations." Ralph W. Steen, Twentieth Century Texas (Austin: The Steck Company, Publishers, 1942), Dp. 36-37.

63 Biennial Report, 1906, pp. 11, 27. 
By 1908 the contract with the Wood County company had been replaced by a similar arrangement with the S. W. Fuel and Manufacturing Company, which had the prisoners working in coal mines near Calvert in Robertson County. The state received $\$ 44.00$ per man for the inmates employed in the Calvert mines. 64 By 1908, the Texas Turpentine Company in Jasper employed 83 prisoners at a cost of $\$ 45$ per month for each of the convicts. 65 Both the mining and turpentine forces were short-lived and had been ended by the fall of 1910.66

Considering both the necessity of placing some prisoners outside the walls of the penitentiaries and the money that could be made from the labor of the prisoners, it is easy to understand the flexibility the state demonstrated in dealing with the private hiring parties. Contractual arrangements that initially appeared less advantageous financially nevertheless received careful consideration from state officials who knew they had to

64 Biennial Report, 1908, pp. $10,31$.

65 Ibid. Part of the reason state officials disliked hiring prisoners to the turpentine companies derived from the "unusually hazardous" nature of the work. "Minutes of the Penitentiary Board Meeting, July 10, 1907," Thomas M. Campbell Papers. Texas State Archives and Library, Austin, Texas.

66 Biennial Report, 1910, pp. $35,88$. 
find something for the prisoners to do. One questionable financial arrangement which was presented to the state during the recession of the mid-1880s ultimately proved to be very profitable for the prison system.

General business prostration struck Texas during 1883 and 1884. Money was tight, manufactured goods as well as farm crops were difficult to sell for ready cash, and there was a "general decline in both the passenger and freight traffic of the different railroads in the State. . . " The economic difficulties forced the railroads to return to the prison many of the inmates they had hired earlier. The state thus held many prisoners for whom it had no work. Prison officials searched anxiously for some type of employment for the prisoners that would make them at least self-sustaining. 67

A way out of the state's predicament came when prison officials entered into contract with several farmers to use prison labor on their farms and share the proceeds of the crop with the state. Just as the crops would be shared, so would the effort to bring them forth. The farmers would furnish the land, free of rent, tools, wagons, forage for the work animals, and housing accommodations. They aiso would pay to transport the prisoners from Huntsville to their respective farms. The state, in

67 Biennial Report, 1884 , pp. 50-51. 
return, obligated itself to provide "the convict labor and guards, clothe and feed them, and pay all expenses incident to the guards and convicts." The crops grown on the share farms would be equally divided between the state and the farmers. 68

The hesitation of state officials to enter the share agreements primarily stemmed from the realization that all profits were tied to the crops produced and their fluctuating values. A poor crop year would mean no profits even though the prisoners would be kept busy. As it turned out, however, the share farms did reasonably well. Beginning with two contracts in 1884 , the state added two more in 1885 and, by 1886, had a total of seven share farms. The state's earnings in these ventures totalled $\$ 26,810.84 .69$ Not all of the farms earned a healthy profit, but enough did to result in good earnings even in times when some of the farms might have shown a net loss. For the period 1886 through 1908, the state earned a clear profit of slightly over $\$ 660,000.00$ from the prisoners working the share farms. 70

68 Ibid.

${ }^{69}$ Ibid.; Biennial Report, 1886, p. 92.

70 By 1910, the state was demanding of the share farm owners a 60 percent-40 percent division of the crop with the state getting the larger percentage. See Biennial Report, 1886, p. 92; Biennial Report, 1888, Exhibit H, P. 9; Biennial Report, 1890, D. 132; Biennial 
The profits made in the share agreements were not the only benefit which went to the state. As time passed, and as the farms prospered, prison officials came to realize that substantial sums of money could be earned from farming despite the unpredictable factors affecting the yearly production and prices. There would be enough good years to offset and compensate for the times when crops were poor or prices low. Having come to this conclusion, prison officials worked actively to convince the legislature it should buy state farms on which to work prisoners.

The state acquired its first sizable farm at the time it abrogated the lease with Cunningham and Ellis. As part of the final settlement, state officials purchased the Wynne farm, located about two and one half miles from Huntsville, for $\$ 21,000$. The farm comprised approximately L1,900 acres, with good fencing, a prison house, and was "well stocked with teams and farming implements. . . ." Financial Agent Brahan admitted that the soil of the farm, "Iike most of that in Walker County," was not of the highest quality, but the property was valuable to the prison system nonetheless. Because of its proximity to

Report, 1892, p. 109; Biennial Report, 1894, p. 95; Biennial Report, 1896, p. 98; Biennial Report, 1898, p. 92; Biennial Report, 1902 , p. 124 ; Biennial Report, 1904 , p. 133; Biennial Report, 1906 , p. 103; Biennial Report, 1908, ?. 109; Biennial Report, 1910, Р. 15 . 
the main unit in Huntsville, prison officials could employ on the farm those prisoners who, as a result of broken health or physical infirmity, could not be placed at the more demanding contract labor. Such prisoners otherwise would have been a "dead weight" on the system. 71 Within a few months of its purchase, the Wynne farm began paying handsome dividends. It produced enough cotton, corn, vegetables, and animal fodder to supply all of its own needs with enough left over to help fill the needs of the Huntsville unit. Much of the cotton from the farm went into the manufacture of prison clothing, although some was made into "lowells and duck" for sale Lon the open market. ${ }^{72}$

$\Gamma$

The success of the Wynne farm demonstrated quite L clearly the advantages of state ownership of prison farms. Financial Agent Brahan urged state legislators to stop thinking of building additional prisons and think, instead, of buying farms "in different sections of the State, where lands are rich and productive. . ." Frisoners could improve the lands and construct all necessary buildings so that if, at some future time, the state wished to sell the property, it would not be difficult to recoup the original investment. Brahan expressed

71 Biennial Report, 1884, pp. 7, 41-41. 72 Ibid., pp. $41-42$. 
particular interest in state farms as a means to employ the "surplus short time convicts" who had no skills and whose length of sentence precluded learning any profitable trade. ${ }^{73}$

The vigorous endorsement of state farms as a solution to some of the prison problems began rather quickly to bring results. In september, 1886 , the state bought The Harlem plantation for $\$ 25,000$. The farm, containing 2,500 acres, lay "in the Brazos [River] bottom," on Oyster Creek near the town of Richmond in Fort Bend County. At the time of purchase, Harlem had a brick sugar house, a sugar mill, several tenant houses, livestock, and direct access to the Galveston, Houston and San Antonio Railroad. The land was considered "as rich as any on Oyster Creek. . . ."74

Shortly after the purchase of the Harlem farm, the state invested additional monies to buy smaller tracts of land adjoining the property. Further outlays were made for equipment for the sugar mill, and materials needed to install permanent ditching and bridges. 75 In all, the state spent slightly over $\$ 122,000$ improving the Harlem facility. 76
${ }^{73}$ Ibid., p. 55.
74 Biennial Report, 1886, p. 20.
75 Biennial Report, 1888 , pp. 15-18.
76 Biennial Report, 1890, p. 24. 
The financial returns on the investment came almost immediately. In 1887, Harlem yielded a net profit to the state of $\$ 10,502.67$. By the end of 1890, the farm had earned profits in excess of $\$ 167,000.00$, approximately $\$ 20,000.00$ more than the combined cost of the land and all improvements. Prison officials found themselves with a piece of property owned entirely by the state and valued at $\$ 200,000.00^{77}$

Despite the relative ease and speed with which the Harlem farm established itself and began returning healthy profits, the state did not rush to buy additional farm property. I. A. Whatley, who became superintendent in 1891 under Governor James Hogg and served through the 1890s, repeatedly urged state leaders to adopt the plan for working convicts on state farms. He pointed to the successes at Harlem as proof of the wisdom of his suggestions. ${ }^{78}$ Whatley's words were echoed by the two financial agents during the decade, R. W. Finley and J. S. Rice. Both of these men expressed dissatisfaction with the outside contract system and advocated state farms as the preferred method of penal management for Texas. ${ }^{79}$

77 Ibid., pp. $24-25$.

78 Biennial Report, 1892 , pp. 14-15; Biennial

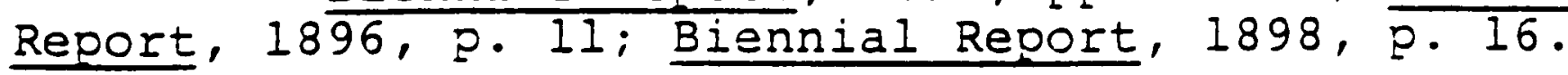

79 Biennial Report, 1892, p. 98; Biennial Report, 1894, p. 81; Biennial Report, 1896, p. 87; Biennial Report, 1898 , p. 81 . 
The pleas of the prison officials failed to bring about any substantive improvement. Even though the prison population during the 1890s increased sharply from 3,199 to 4,109, state leaders permitted more and more of the prisoners to be consigned to the contract camps rather than purchase additional state farms to hold them. 80 Governor Hogg unsuccessfully attempted to make available to the prison system $\$ 300,000$ from the general school fund to purchase farmland, but Attorney-General Charles Culberson deemed the transfer to be in violation of the state constitution. When a constitutional amendment to approve the action was presented to the voters in November, 1896, it failed. Edward M. House, confidant of both Governor Hogg and Attorney-General Culberson, wrote a few years after the electoral defeat that the amendment failed in large part from "sheer lack of attention." Apparently no one in state government felt strongly enough about the amendment or had the political clout necessary to conduct an active public campaign in its behalf. 81 Not until three years after the voters rejected using school funds did the state make additional money available to invest in farmland.

\footnotetext{
80 Biennial Report, 1890 , p. 56 ; Biennial Report, 1900, p. 8.

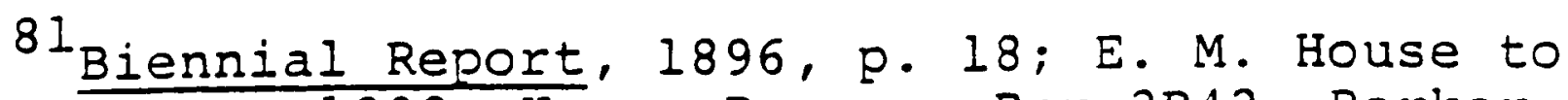
T. S. Henderson, 1898, House Papers, Box 2R42, Barker Texas History Center, The University of Texas at Austin, Austin, Texas. 
On December 9, 1899, the state purchased 5,527 acres of land in Brazoria County. The property, which would become known as the William Clemens farm, lay between the Brazos and San Bernard rivers about nine miles north of the town of Velasco. The soil was considered to be "exceptionally fertile," in an area that had long been known as the "Sugar Bowl District of Brazoria county. . . ." Two and one-half miles of the property fronted directly on the Brazos River. 82

Under the purchase agreement, the state paid $\$ 44,216.00$ for the property $(\$ 8.00$ per acre). At the same time, state officials leased the adjoining Lowood plantation consisting of $2,685.47$ acres. The lease terms stipulated that the rental price would be $\$ 2.00$ an acre with the state having an option to buy the land later for $\$ 12.31$ an acre. The state exercised the option to buy almost immediately so that within a few months, the Clemens farm included $8,212.47$ acres for which $\$ 77,261.40$ had been paid. Prison officials estimated that the Brazoria County property could provide employment for up to four hundred prisoners. 83

Shortly after the purchase of the Clemens farm,

82 Biennial Report, 1900, D. 12; Biennial Report, 1902 , p. 21; William Clemens was chairman of the penitentiary board at the time the farm was purchased.

83 Ibid. 
the state invested heavily in a new large capacity sugar mill that could "grind 900 tons of sugar cane every twentyfour hours. . . " The cost came to $\$ 268,500$. Prison officials then had a railroad built from the sugar house to the landing on the Brazos River. The expense of these improvements left the Clemens property under heavy debt for several years. 84

Following the successful establishment of the farm in Brazoria County, state officials demonstrated a greater degree of enthusiasm for the idea of state owned and operated farmland. During 1908, three farms were purchased. Two of the farms, known as Imperial and Ramsey, were to be operated as individual agricultural units, while a third, the Riddick farm, became part of the Harlem plantation. The prison board bought all three pieces of property by pledging to the former owners 40 percent of the crop at 6 percent interest until the total purchase price had been paid. 85

The Imperial farm, located in Fort Bend County, consisted of 5,235 acres of land. The Sartartia plantation, which had originally belonged to L. A. Ellis, formed the bulk of the property. Following Ellis' death the

84 Biennial Report, 1902, p. 21; Biennial Report, 1904, p. 4; Biennial Report, 1906, p. 14.

85 Biennial Report, 1908, p. 15; Biennial Report, 1910, pp. 17-18. 
property passed into the hands of the Imperial sugar Company, whose directors sold it to the state for $\$ 160,000$ plus interest. According to J.A. Herring, superintendent of prisons at the time the farm was purchased, the price included all livestock as well as lands and structures. The farm was paid in full in two years at a total price, including interest, of $\$ 165,000.86$

The Ramsey farm, 7,762 acres along Oyster Creek in Brazoria County, also included several former plantations-Waverly, Drayton, Quarl, Smith, and Palo Alto. The state acquired it for $\$ 13.75$ per acre from Bassett Blakeley, a vice-president of the Imperial Sugar Company and a former contractor of prison labor. He had purchased the land in 1905 for $\$ 5.00$ an acre but justified selling it at $\$ 13.75$ an acre because, in the few years he had owned it, he had made many improvements at his own expense. Superintendent Herring acknowledged the farm to be "one of the best tracts of land in the State, and will, when properly developed, be decidedly the most valuable property the State owns. . . ."87

86 Biennial Report, 1908 , p. 15; Biennial Report, 1910, pp. 17-18; Report of the Penitentiary Investigating Committee including All Exhibits and Testimony taken by the Committee (Published by order of the House of Representatives, August, 1910), pp. 692-697; A Record of Evidence and Statements before the Penitentiary Investigating Committee Appointed by the Thirty-third Legislature of Texas (Austin: A. C. Baldwin and Sons, 1913), pp. 71-72. 87 Biennial Report, 1908 , p. 15; Biennial Report, 
Herring also considered the Riddick place to be of excellent quality. C. W. Riddick had used prisoners for several years on his land which was near sartartia in Fort Bend County. The 957 acres were sold to the state for $\$ 40$ per acre. The addition of the Riddick property enlarged the Harlem prison farm to 3,740 acres. 88

The acquisition of the farm property in 1908 constituted a major investment for the state in terms other than merely financial. Elected officials and prison administrators expressed in concrete terms their preference for working prisoners on state account rather than exclusively under contract to outside individuals. From 338 prisoners on state farms in 1906, the number jumped dramatically to 1,064 by the end of $1908 .{ }^{89}$ The overwhelming dependence on contract labor that had been the hallmark of state prison management for 25 years gave way to a mixed

1910, p. 17; Report of Evidence before Penitentiary Investigating Committee, 1913, p. 226; Abner J. Strobel, The Old Plantations and their Owners of Brazoria County, Texas (Houston: Union National Bank, 1930 [1926], pp. 36-37; "Report of Meeting of Penitentiary Board, July 10, 1907," Thomas M. Campbell Papers. By January 11, 1911, the Ramsey farm had been paid in full. Message of Governor T. M. Campbell to the Thirty-second Legislature of Texas (Austin: Austin Printing Company, 1910), p. 32 . Biennial Report, i902, p. 38; Biennial Report, 1904, p. 38; Biennial Report, 1906, p. 28 ; Biennial Report, 1908, p. 15; Biennial Report, 1910, p. 17.

${ }^{89}$ Biennial Report, 1906, pp. 28-28; Biennial Report, 1908, p. 31 . 
system which sought to strike a balance between those prisoners working for the state and those hired out to private parties.

At about the time prison officials moved away from the total reliance on contract labor, events began to unfold elsewhere that ultimately helped end the contract labor system in Texas. In the fall of 1908, the Reverend Jake Hodges, chaplain at the Huntsville unit, made the acquaintance of George Waverley Briggs, a young reporter for the San Antonio Express. Hodges told the young newsman of the many problems within the prison system and of the obstacles he had encountered as a chaplain trying to perform his duties. 90

Hodges had been a thorn in the side of prison administrators for quite some time prior to the fall of 1908. Superintendent Herring had complained to Governor Campbell earlier that the chaplain had interfered repeatedly in disciplinary matters and had questioned the circumstances surrounding every instance of corporal punishment of a prisoner. According to Herring, Hodges was easily influenced by the pitiful stories the convicts would relate to him of their treatment and used his position as chaplain to initiate requests that the prisoners wanted

\footnotetext{
90 Tom Finty, Jr., "The Texas Prison Investigation," Survey 23 (December 18, 1909): 387.
} 
to relay to the governor and members of the prison board. ${ }^{91}$ Hodges' notoriety extended even to the prison board itself. W. F. Ramsey, chairman of the board, on one occasion wrote to A. M. Barton, secretary to Governor Campbell, expressing concern about Hodges and suggesting possible ways to deal with the chaplain. Ramsey believed Hodges to be an "indiscreet" individual who "has permitted his sensitive nature to lead him to do a good many things he shouldn't do." Ramsey wanted Barton to persuade the governor to inform the chaplain that "he must mend his ways. . ." Hodges had to be made to understand that, "we cannot stand for anything to undermine the discipline or cause trouble at Huntsville or anywhere else along the line." Ramsey offered to make his feelings known directly to the chaplain if the governor would order Hodges to appear before the prison board. 92

At the time Hodges unburdened himself to Briggs, the young reporter had been out of school only about two years. The enthusiasm with which he began his investigation into prison affairs strongly resembled the efforts of

${ }^{91} \mathrm{~J}$. A. Herring to Thomas M. Campbell, September 26, 1907, Thomas M. Campbell Papers.

92 W. F. Ramsey to A. M. Barton, September 30 , 1907, Thomas M. Campbell Papers. Shortly after Briggs began publishing the results of his investigation of the prison, Chaplain Hodges was fired. Report of the Penitentiary Investigating Committee, 1910, p. 156. 
other journalists and writers, Upton Sinclair, Ida Tarbell, and Lincoln Steffens, for example, to ferret out and expose corruption and maladministration in other areas of American life. Briggs visited the penitentiaries and convict camps around the state. Subsequently, he published the findings of his investigation in a series of Express articles from December 5, 1908 through January 11, 1909. Among the many criticisms and revelations he presented, Briggs scored most severely the fact that the prison system was geared almost exclusively to making money with very little effort being expended to reform the prisoners. To Briggs, the administration of the state prisons appeared "wrong and harmful not only to the criminal himself but to the society that is as deserving of protection as the moral defective is of treatment. . . ." He argued that the spirit of the age demanded a fundamental change in the way the prisons in Texas were operated so that they would "more nearly accomplish the will of the people, effect their protection and execute the precepts of humanitarianism coincidently [sic]." 93

At first, state leaders expressed great skepticism about Brigg's contentions. Governor Campbell, in a message

${ }^{93}$ George Waverly Briggs, The Texas Penitentiary, History of the Texas Convict System and Suggestions for Its Betterment (San Antonio Express, n.d.), p. 5; Finty, "Texas Prison Investig ation," p. 387 . 
to the Thirty-first Legislature in January, 1909, responded that his prison officials had all performed their respective duties in an exemplary manner.

The reports of the Board of Commissioners, the Superintendent and other officials show that the affairs of the system [prison] have been for the past two years most efficiently managed, that the convicts are properly housed, clothed and fed, and that they have ment. 94 times received considerate and humane treat-

Campbell went on to admit, however, that the "persistent character" of the "recent agitation" had led him to believe that a thorough investigation of the prison should be undertaken.

The good name of the State demands that this be done. Such investigation should be searching, sweeping, and effective, to the end that any abuses, if found, can be speedily arrested, and that trusted officials may be vindicated if free of fault or wrong.95

The lieutenant governor appointed four of the committee members from the senate. The other five came from the House and were selected by the speaker. The committee began its work on July 15, 1909. 96

Reporters from several leading newspapers of the

94 Message of Governor T. M. Campbell to the ThirtyEirst Legislature of Texas to which is Appended the State Democratic Platform adopted at San Antonio, Texas, Auqust 13, 1908 (Austin: Von Boeckmann-Jones Co., Printers, 1909), p. 21 .

$$
95 \text { Ibid., pp. 21-22. }
$$

96 Report of the Penitentiary Investigating Committee, 1910, pp. i, vi Einty, "Texas Prison Investigation," p. 338 . 
state traveled with the investigating committee to the various prison camps. Other papers picked up their bylines so that word of the investigation was disseminated widely. According to one source, by the time the report of the investigation was sent to Governor Campbell in November, 1909, the "people and the press" of the state already favored "genuine prison reform in Texas." It remained only for public pressure to be brought against the politicians, who "as usual," were "slow to trust the people." 97

The information made public by the legislative investigating committee revealed a pitiful state of affairs in the prisons. Mismanagement, inefficiency, waste, and brutality toward inmates remained commonplace in 1909 just as they had been since the resumption of state control in 1883. Investigators discovered that many prison employees, especially in the outside camps where abuse of prisoners occurred more frequently, conducted affairs in their respective departments ignorant or unmindful of any regulation which might have had a bearing on their work. ${ }^{98}$

An independent auditing firm hired to examine the

97Finty, "Texas Prison Investigation," pp. 388-389.

98 Report of the Penitentiary Investigating Committee, 1910, pp. 7-15. 
books of the prison system found that accounting procedures had been so haphazard and unprofessional that a true picture of the system's finances could not be had. The firm discovered, for example, that no permanent records had been kept of the industries in the Rusk and Huntsville units. Moreover, very little coordination existed between the outside camps and the financial agent's office so that, in effect, neither knew what the other was doing. 99

The release of the information in the report prompted elected officials to take action. In september, 1910, the legislature meeting in special session passed a bill making sweeping changes in the structure of the prison administration. The new law would take effect January 20, 1911.100

The legislature stated clearly that the new policy of the state provided for the working of prisoners only "within prison walls, and upon farms owned by the state. . ." The prison board received instructions to "change from the system of leasing and hiring out of prisoners at the earliest practicable time." Under no circumstances would prisoners be hired or leased to private

${ }^{99}$ Ibid., pp. 133-138.

100 Tom Finty, Jr., "Troubles of the Texas State Prisons," The Delinquent 3 (December 1913): 4. 
individuals after January 1, 1914.101

The law further stated that the management and control of the prison system would be vested in a board of prison commissioners, to be composed of three men chosen by the governor and approved by the senate. The commissioners would serve two-year terms and would receive a salary of $\$ 300$ per month to work full-time for the prison system. Complete responsibility for all prison matters rested with them and they could be removed from office in the event of prisoner mistreatment or neglect. One of the commissioners would have responsibility for all financial transactions of the prisons; another would see to the care and treatment of prisoners; while the third would supervise all officers and employees of the system. The positions of superintendent and financial agent were abolished. 102

Shortly after taking office, in 1911, Governor O. B. Colquitt appointed the members of the new board. They included Ben E. Cabell, former sheriff of Dallas

\section{$10 I_{\text {Report of the Penitentiary Investigating Com- }}$} mittee, 1910, p. vii.

102 Ibid., pp. viii-ix. The authors of the prison reorganization legislation initially had intended to preserve the prison management structure with few changes. As debate on the bill ensued, however, lawmakers succumbed to "an eloquent plea in behalf of the 'commission form of government, " and divided authority accordingly. Tom Finty, Jr., "Troubles of the Texas Prison System," The Delinquent 4 (January 1914): 7 . 
County and mayor of the City of Dallas; Louis W. Tittle, merchant and former County Clerk of Cherokee County; and Robert W. Brahan, "who for many years had been connected with the prison system as sales agent and in other capacities." These men, working with the governor, would execute the new law and preside over the demise of the contract system. 103

On May 20, 1911, the prison board announced its intentions of ending outside contract labor before the mandated date of January 1, 1914. Word went out that no contracts then in force would be renewed and the board would be willing to accept the early surrender of any of the outside forces. By the end of 1911, the number of contracts had been reduced greatly and by the close of 1912, the contract labor system had been "entirely abolished." 104

The decision to end the hiring out of prisoners before the scheduled date, while admirable in its intent, placed severe financial strains on the prison system. In the absence of generous appropriations from the legislature to compensate for the lost contract revenue, prison

103Finty, "Troubles of Prison Prisons," p. 4. It could not be determined whether Robert $W$. Brahan was related to Haywood Brahan. Such a connection is likely, however, given the prominence of the earlier Brahan in prison operations.

104 Ibid.; Report of Evidence before Penitentiary Investigating Committee, 1913, Pp. 14-15. 
officials were forced to "buy supplies at credit prices and to sell products at distress prices. . . " Since there was not enough room in the prisons and on the state farms to house and employ all the inmates, the board adopted the policy of leasing land for "money rent" from private landowners so that prisoners could be worked under state control. The problems eased somewhat in the summer of 1913 when the legislature voted $\$ 500,000$ to take care of the system's immediate needs, plus granted authorization to issue $\$ 1,500,000$ in prison bonds. 105

Ending the contract labor system in Texas placed the burden of financial support for state prisoners squarely on the shoulders of the state's taxpayers. Prisoners would continue to work and produce on the state farms, and the number of such farms would increase over the next few years as additional lands were purchased. But any economic shortfall in prison financial operations would have to be covered by legislative appropriations. The generous income from the private contractors became the first casualty of the state's attempts to bring the management of its prisons into conformity with national standards.

In assessing the outside contract labor system in the continuum of penological development in the state, it

105Finty, "Troubles of Texas Prisons," pp. 4-5; Report of Evidence before Penitentiary Investigating Committee, 1913, p. 14 . 
might be characterized as a transtional stage. The lease system in which the state abdicated all but the most nominal expressions of responsibility for its prisoners yielded to the contract system in which a greater measure of state influence in the form of inspection was brought to bear. Dissatisfaction with the practice of hiring out the prisoner labor to private parties led to the third and last stage wherein the prisoners were placed under the exclusive control of the state.

At least a modicum of avarice figured in the decision to choose the contract system to replace leasing. State officials hoped to reap the rewards of hiring out the prisoners to private parties just as the lessees had done while making provision for increased state inspection of the outside forces to prevent abuse and neglect of the inmates. The convict labor did earn large revenues for the state, but as the 1910 legislative investigation revealed, the abuse of prisoners in the contract forces continued at unacceptably high levels. The state thus abandoned contracting, with its lucrative monetary returns, and committed itself to large-scale state farming as the next step in prison management.

Relatively speaking, the state had established a good position from which to make an excellent start at state farming. The farms that had been acquired since the end of leasing in 1883, especially those in the Brazos 
River bottoms, possessed very rich productive soils and good drainage. They had made money for the former owners, had shown excellent initial profits for the state, and under proper management would continue to be good investments.

Hiring the prisoners out to private individuals likely would have continued well into the twentieth century had the state been able to curb the abuse and neglect of the inmates in the outside camps. Newspaper articles in 1908 and 1909 describing living conditions in the contract forces generated irresistible public pressure to bring all prisoners under state control. By the end of 1912, the practice of leasing state prisoners had ended completely. 
CHAPTER V

\section{THE PRISONER'S LOT}

The efforts by state officials to establish and maintain a prison system during the last half of the nineteenth century represented only one side of a multifaceted story. The growth of the prisons demonstrated considerable progress and presented a record of achievement which kindled the optimism of those who wished to see the system become a large-scale industrial and agricultural enterprise operated efficiently by and for the benefit of the state. By 1913, the main unit at Huntsville, the penitentiary at Rusk, and the several state farms gave state leaders the flexibility to embark upon new economic ventures in the prisons with a reasonable chance of success. Such assurance had not been so obvious in 1883 when the leases of the prisons had been terminated. In areas other than the acquisition of land structures, and property, however, the prison system record of achievement during the late nineteenth and early twentieth centuries remained considerably less lustrous. In such things as prisoner care and treatment, those amenities which figured prominentiy in the reform aspect of 
incarceration, the situation did not change much in the years 1871 to 1913. Some improvement occurred in a few areas of prisoner management, but the inmates in 1913 generally were subject to the same sorts of abuse and neglect that their predecessors had endured many years earlier.

This chapter will attempt a closer examination of the prisoners themselves. It will look at the racial composition of the prison population, the personal characteristics of the inmates, the crimes they had committed, and the conditions under which they lived. It will be necessary also to determine the reasons for any failures on the part of the state to provide for its convicted felons in the manner stipulated by the prison rules and regulations.

Tables 1 through 7 describe statistically the changing prison population for the period 1870 through 1912. The average inmate was a non-white male, in his twenties, born in Texas. He was serving a first-term sentence of less than five years for the non-violent crime of theft or burglary. Furthermore, he had no particular skill or profession and little or no formal Schooling when he entered prison. ${ }^{1}$

\footnotetext{
1 Information on the personal characteristics of
the prisoners appeared in the biennial reports which were published in the late fall of the even-numbered years. All of the reports for the years 1870 through 1912 listed the population of the prison at the time. Frequently,
} 
The figures shown in Table 1 reveal an increase in the prison population of approximately 700 percent in the space of just over one generation. ${ }^{2}$ population figures

however, the reports for the 1870 s were incomplete and contained information that was contradictory. Not until the 1880 report, the first for which Thomas Goree bore full responsibility, did a more complete picture of the inmates emerge. For that reason, with the exception of Table 1 , all of the statistical exhibits are drawn only from the Lreports for 1880 through 1912 .

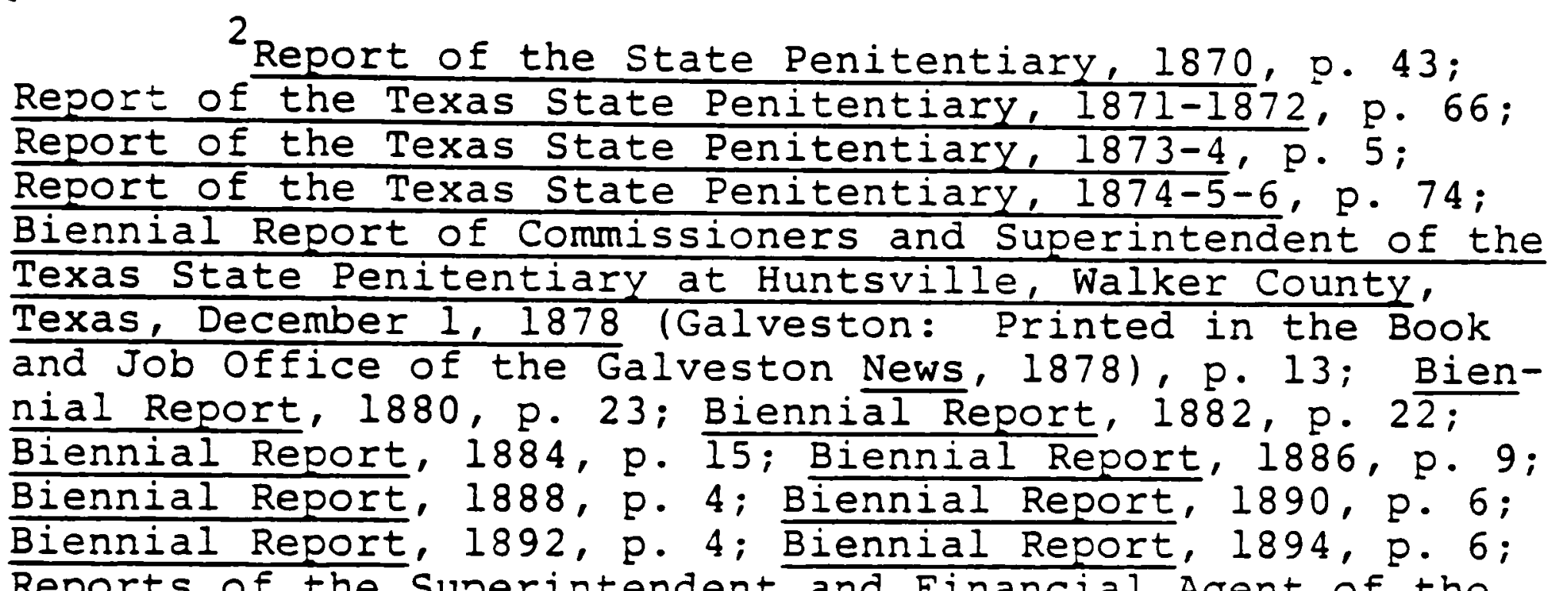

Reports of the Superintendent and Financial Agent of the Texas State Penitentiaries Embodying Statistical and Financial Exhibits; Also Reports of Subordinate Officers of the Texas State Penitentiaries, for Two Years Ending October 31, 1896 (Austin: Ben C. Jones and Co., State Printers, 1896), p. 6 ; Biennial Report, 1898 , p. 8; Biennial Report of the Superintendent of Texas state Penitentiaries for Two Years Ending October 31, 1900 (Austin: Von Boeckmann, Moore and Schutze, State Printers, 1900), p. 8; Biennial Report of the Commissioners, Superintendent and Financial Agent of Texas State Penitentiaries for Fiscal Years Ending August 31, 1902 (Austin: Von Boeckmann, Schutze and Co., State Printers, 1902), ․ 15; Biennial Report, 1904, p. 11; Biennial Report, 1906 , p. 6 ; Biennial Report, 1908 , p. 5; Biennial Report, 1910 , p. 9; Annual Report of the Officials of the Texas Prison system for the Year Ending December 31, 1911 (Austin: Von Boeckmann-Jones Co., Printers, 1912), p. 20 . 
TABLE 1

PRISON POPULATION, 1870-1912

\begin{tabular}{|c|c|}
\hline Year & $\begin{array}{c}\text { Total Number of } \\
\text { Prisoners }\end{array}$ \\
\hline 1870 & 489 \\
\hline 1872 & 944 \\
\hline 1874 & 1,453 \\
\hline 1876 & 1,723 \\
\hline 1878 & 1,738 \\
\hline 1880 & 2,157 \\
\hline 1882 & 2,278 \\
\hline 1884 & 2,539 \\
\hline 1886 & 2,859 \\
\hline 1888 & 3,302 \\
\hline 1890 & 3,199 \\
\hline 1892 & 3,575 \\
\hline 1894 & 4,125 \\
\hline 1896 & 4,421 \\
\hline 1898 & 4,474 \\
\hline 1900 & 4,109 \\
\hline 1902 & 3,865 \\
\hline 1904 & 3,975 \\
\hline 1906 & 3,864 \\
\hline 1908 & 3,466 \\
\hline 1910 & 3,578 \\
\hline 1912 & 3,471 \\
\hline
\end{tabular}


for the entire state for the same period reflect an increase of only about 500 percent. The disparity in the two growth patterns most likely stems from several sources, including better and more vigorous enforcement of laws, a concomitant to the reestablishment of public order and the growth of urbanization in the last quarter of the nineteenth century. During this period also the state government extended its influence into the more remote western portion of the state, thus bringing to that region the legal structure of civil government that held lawbreakers accountable for their crimes. The racial composition of the prison (as shown in Table 2), also provides clues to help explain the extraordinary increase in the prison population. 3 The large number of blacks serving time Throughout the entire period of this study exceeded by a considerable margin their percentage of the population as a whole. In 1870 , the federal census revealed 253,475 blacks living in Texas. By 1910, the number had grown to 690,049. Notwithstanding this increase in the total number, however, the percentage of the population listed as black

3 Biennial Report, 1880 , p. 49; Biennial Report, 1882 , p. 23; Biennial Report, 1884 , p. 32; Biennial Report, 1886 , p. 35; Biennial Report, 1888, p. 27; Biennial Report, 1890 , p. 55; Biennial Report, 1892, p. 28; Biennial Report, 1894 , p. 31; Biennial Report, 1896, p. 30 ; Biennial Report, 1898 , p. 28; Biennial Report, 1900 , p. 28; Biennial Report, 1902 , p. 36; Biennial Report, 1904, p. 36; Biennial Report, 1906 , p. 26; Biennial Report, 1908, p. 30; Biennial Report, 1910, P. 34; Annual Report, 1911, ?. 31 . 


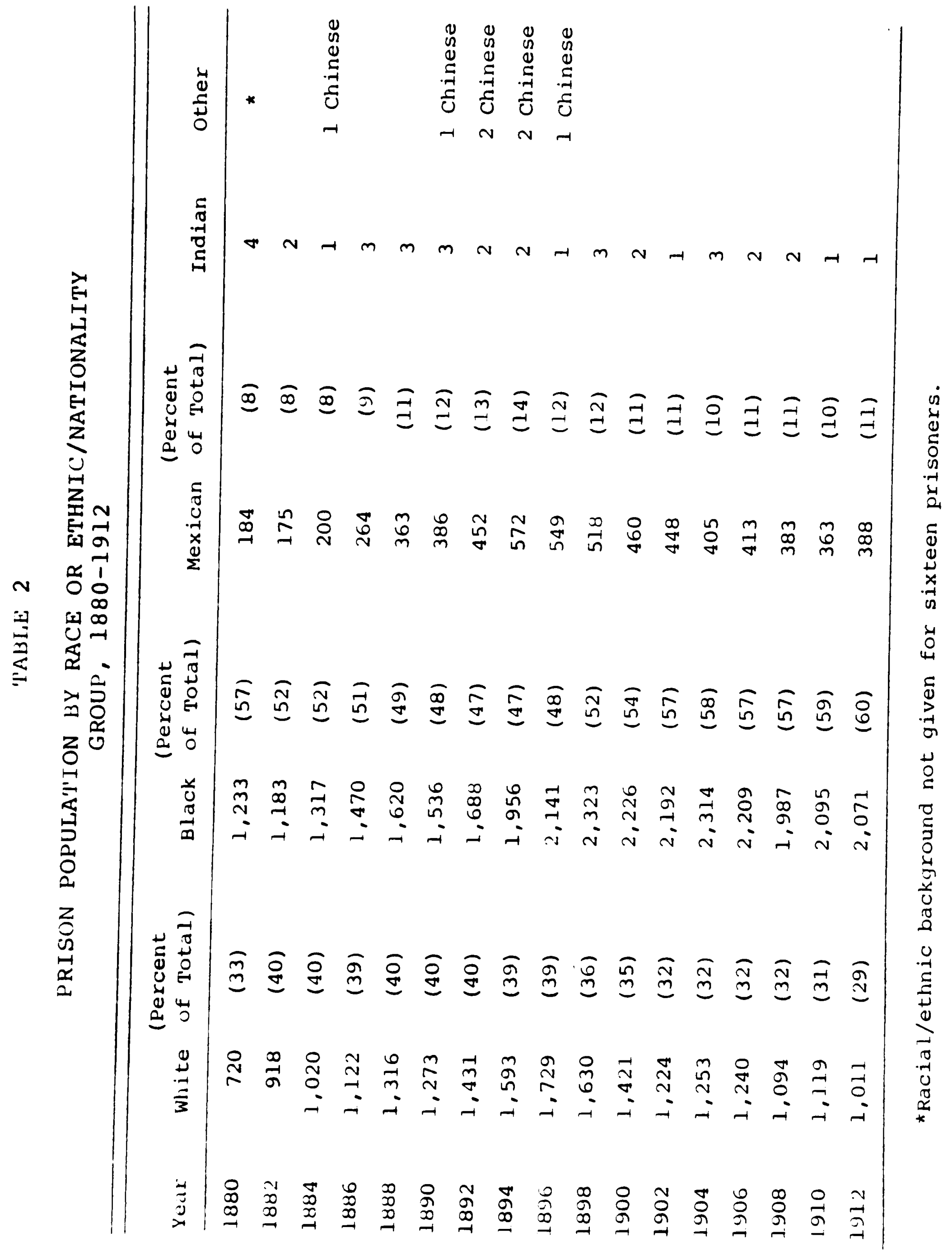


declined from 31 percent to 18 percent in relation to the majority population which grew from 564,700 to $3,204,848$ over the same period. Yet blacks seldom accounted for less than 50 percent of the prison population and frequently approached 60 percent. 4

The principal explanation for the preponderance

of blacks among the inmate population in this period can be found by examining their status in Texas society at ' the time. With regard to the legal system, black Texans existed essentially outside the protections of law. For the most part, their straitened financial circumstances Frendered them unable to avail themselves of legal counsel to defend their interests in court. They became, in effect, passive participants in any legal matters in which they were involved; the laws acted upon them rather than the reverse. In addition, the majority policies of systematically excluding blacks from jury service and of discounting their testimony further removed them from any active role in judicial matters. The threats and intimifation vented against black voters by county-level all

4 Department of the Interior, The Statistics of the Population of the United States, Embracing the Tables of Race, Nationality, Sex, Selected Ages, and Occupations, Jinth Census, vol. I (Washington, D.C.: Government Printing Office, 1872): x-xvii; Department of Commerce, Bureau of the Census, Thirteenth Census of the United States Taken in the Year 1910, vol. 3, Population (Washington, D.C.: Government Printing Office, 1913): 804. 
white political organizations, which began to appear in the latter decades of the nineteenth century, and the poll tax, which was adopted early in the twentieth century, effectively closed to this minority segment of the population the political avenues to redress grievances. 5

\section{Alwyn Barr, Black Texans, A History of Negroes in} Texas, 1528-1971 (Austin: Jenkins Publishing Company, 1973), Pp. 83-84; Lawrence D. Rice, The Negro in Texas, 1874-1900 (Baton Rouge, La.: Louisiana State University Press, 1971), pp. 113-139 and 240-257. Two previous studies of the Texas prison system during the lease and contract periods have attempted to explain the large number of blacks in the prison as having resulted from the enactment of laws designed specifically to entrap the former slaves and feed them into the prison system. According to the argument, the Democrats, who returned to power in the early 1870s, passed what were known as "pig laws," which made theft of small farm animals (supposedly a favorite target of blacks) a felony punishable by confinement in the penitentiary. The evidence simply will not support such an argument.

Table 8 showing the major crimes committed, reveals that the theft of hogs, goats, and sheep was a relatively minor category throughout the entire period of the study. In 1898, the year in which the most people, 191, were in prison for such crimes, the total represented only four percent of the entire prison population. An examination of the laws of the period also questions the arguments made in the previous studies.

The pre-war state penal code that had been adopted by the legislature in 1856 and which went into effect early in 1857 listed specific penalties for the theft of animals. Conviction for stealing "any horse, gelding, mare, colt, ass, or mule" carried a punishment of not less than five nor more than fifteen years in the state penitentiary. Theft of beef cattle, sheep, goats, or hogs carried a penalty of penitentiary confinement for at least two but no more than five years. These statutes were to be enforced regardless of the monetary value of the animals. In November, 1866, the penalties for theft of any "cattle, sheep, goat, or hog" were amended so as to bring them into conformity with the general provisions regarding felony theft. According to the new law, if the stolen animal had a market value of at least $\$ 20$, the punishrnent would be two to five years in the state prison. If, on 
The information in Tables 3,4 and 5 demonstrates that the majority of the prisoners were between the ages

the other hand, the value were less than $\$ 20$, the individual convicted could be sentenced to serve up to two years in the county jail, plus pay a fine of not more than one hundred dollars. The fine would not be charged if the full jail sentence was assessed.

In the 1879 codification of state criminal statutes, adopted following the ratification of the 1875 constitution, the penalties for the larger animals, such as horses, remained the same as the provisions in the antebellum code. The statutes regarding cattle, however, were changed to provide for a prison sentence of two to five years regardless of the value of the animal. Theft of hogs, goats, or sheep remained punishable by a prison sentence of two to five years only if the value of the animal came to at least twenty dollars. The parts of the 1879 penal code dealing with farm animals remained unchanged until March, 1893 when the legislature made theft of hogs a felony equal to that of cattle regardless of the value of the animal, but decreased the penalty for conviction to two years to four years in the state penitentiary. A few years later, the penalty for horse theft was reduced to two to ten years in prison.

No doubt part of the reason for cattle and hog theft becoming such a serious matter late in the nineteenth century had to do with their relative value as compared with the other common types of livestock in the state. In 1900, for example, beef cattle and hogs, along with horses, formed the three most valuable categories of farm animals in Texas. Over the 30 year period, 1870-1900, the number of cattle had increased from approximately $3,000,000$ to just under $6,500,000$ head. The total value of the cattle had grown from $\$ 21,350,000$ to $\$ 77,736,000$, an increase of over 360 percent. During the same time, the number of hogs had increased from slightly over $1,200,000$ to well over $2,600,000$. The monetary value of the animals jumped from $\$ 2,681,000$ to $\$ 10,612,000$, an increase of 390 percent. Blatner, "Some Aspects of the Convict Lease System," p. 19; Parrish, "This Species of Slave Labor," p. 18; Paschal, A Digest of the Laws of Texas, pp. 465-466a; The Penal Code of tine State of Texas passed by the Sixteenth Legislature, February 21, 1879 (Austin: State Printing Office, 1887), p. 97; Gammel, Laws of Texas, 10: 455, 1137; Spratt, The Road to Spindletop, p. 298 . 
TABLE 3

PRISON POPULATION BY AGE, 1880-1912

\begin{tabular}{|c|c|c|c|c|c|c|c|}
\hline Year & Under 15 & $15-19$ & $20-24$ & $25-29$ & $30-34$ & $35-39$ & Over 40 \\
\hline 1880 & 11 & 487 & 621 & 542 & 196 & 132 & $159^{a}$ \\
\hline 1882 & 14 & 495 & 623 & 573 & 219 & 153 & $193^{b}$ \\
\hline 1884 & 31 & 409 & 907 & 566 & 253 & 152 & 221 \\
\hline \multirow[t]{2}{*}{1886} & 55 & 456 & 983 & 603 & 327 & 162 & 273 \\
\hline & Under 16 & $16-19$ & $20-24$ & $25-29$ & $30-34$ & $35-39$ & Over 40 \\
\hline $1888^{C}$ & 55 & 576 & 1,086 & 700 & 377 & 209 & 299 \\
\hline 1890 & 0 & 487 & 1,100 & 697 & 403 & 207 & 295 \\
\hline 1892 & 0 & 578 & 1,196 & 742 & 460 & 248 & 350 \\
\hline 1894 & 10 & 711 & 1,394 & 824 & 262 & 262 & 422 \\
\hline 1896 & 3 & 756 & 1,465 & 838 & 606 & 293 & 440 \\
\hline 1898 & 2 & 760 & 1,413 & 931 & 586 & 294 & 491 \\
\hline 1900 & 17 & 757 & 1,209 & 824 & 549 & 264 & 489 \\
\hline 1902 & 31 & 677 & 1,128 & 763 & 537 & 245 & 484 \\
\hline 1904 & 40 & 711 & 1,116 & 806 & 536 & 242 & 524 \\
\hline 1906 & 30 & 740 & 1,035 & 785 & 540 & 256 & 478 \\
\hline 1908 & 15 & 654 & 929 & 696 & 498 & 228 & 446 \\
\hline 1910 & 11 & 685 & 928 & 769 & 499 & 238 & 448 \\
\hline 1912 & 23 & 660 & 876 & 722 & 483 & 251 & 399 \\
\hline
\end{tabular}

${ }^{a}$ Age not stated for nine prisoners.

bage not stated for eight prisoners.

$c_{\text {After }} 1888$, prisoners below age sixteen were placed in the juvenile house of correction at Gatesvilie. 
TABLE 4

CLASSIEICATION OF PRISON POPULATION BY SEX, 1880-1912

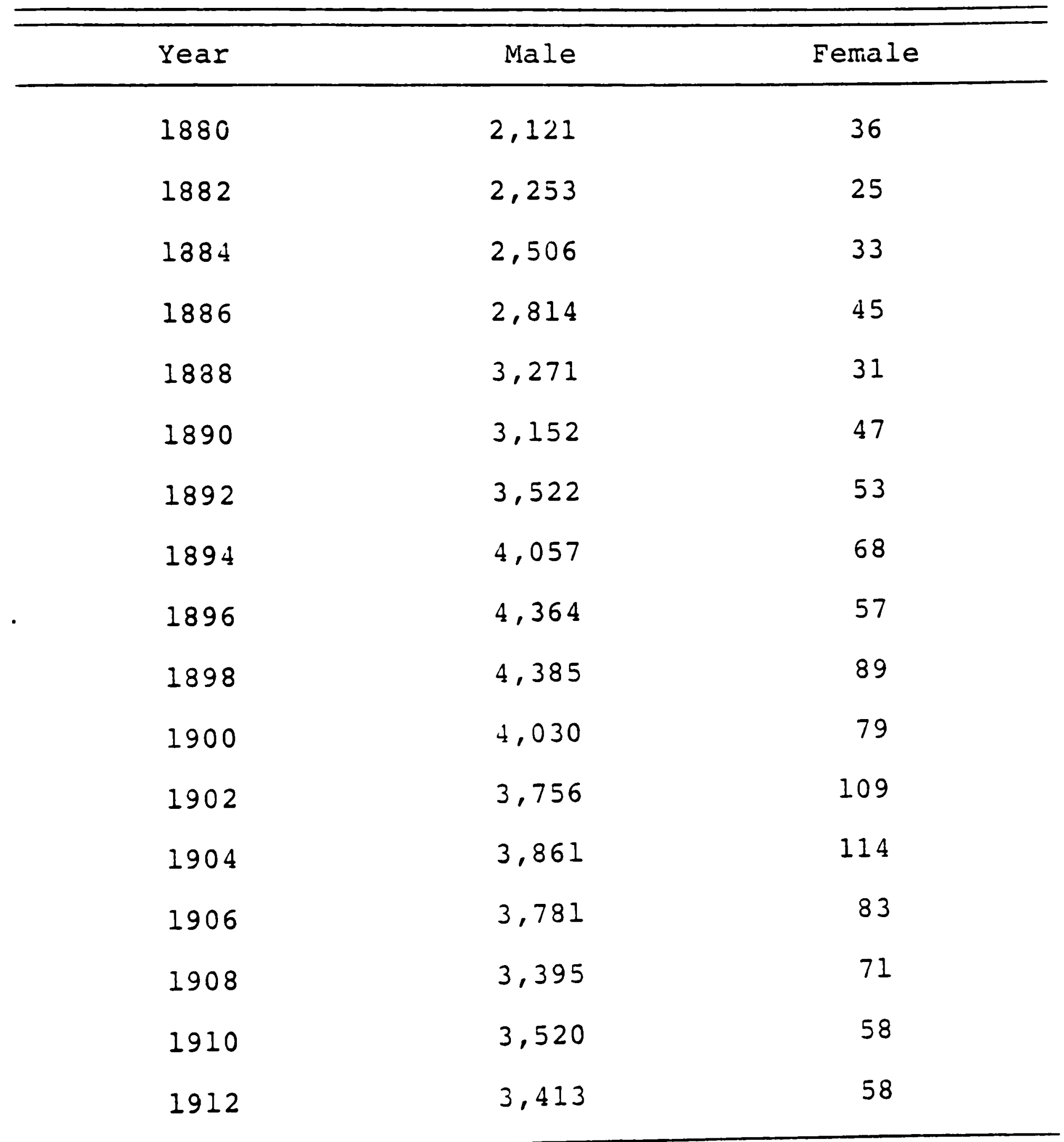


TABLE 5

EDUCATIONAL LEVEL OF PRISON POPULATION, $1880-1912$

\begin{tabular}{|c|c|c|c|c|c|c|}
\hline \multirow{2}{*}{$\frac{\text { Year }}{1880}$} & \multicolumn{2}{|c|}{ Fine-Good } & \multicolumn{2}{|c|}{ Limited-Common } & \multicolumn{2}{|c|}{ Illiterate } \\
\hline & 72 & $(38)$ & 1,317 & $(618)$ & 768 & $(368)$ \\
\hline 1882 & 67 & $(38)$ & 460 & $(20 \%)$ & 1,751 & $(77 \%)$ \\
\hline 1884 & 130 & $(58)$ & 1,048 & $(418)$ & 1,361 & $(548)$ \\
\hline 1886 & 121 & $(48)$ & 1,024 & $(36 \%)$ & 1,714 & $(60 \%)$ \\
\hline 1888 & 116 & $(48)$ & 1,126 & $(348)$ & 2,060 & $(62 \%)$ \\
\hline 1890 & 181 & $(68)$ & 1,026 & $(32 z)$ & 1,998 & $(628)$ \\
\hline 1892 & 324 & $(98)$ & 1,312 & $(378)$ & 1,939 & $(54 \%)$ \\
\hline 1894 & 298 & $(78)$ & 1,776 & $(43 \%)$ & 2,051 & $(50 \%)$ \\
\hline 1896 & 297 & $(78)$ & 1,877 & $(428)$ & 2,247 & $(518)$ \\
\hline 1898 & 68 & $(28)$ & 2,219 & $(50 \%)$ & 2,187 & $(48 \%)$ \\
\hline 1900 & 60 & $(1 z)$ & 2,110 & $(51 \%)$ & 1,939 & $(48 \%)$ \\
\hline 1902 & 0 & & 1,950 & $(50 \%)$ & 1,915 & $(50 \%)$ \\
\hline 1904 & 298 & $(88)$ & 1,826 & $\left(46 \frac{7}{3}\right)$ & 1,851 & $(46 \%)$ \\
\hline 1906 & 320 & $18 \%$ & 1,742 & $(458)$ & 1,802 & $(478)$ \\
\hline 1908 & 220 & $(6 \%)$ & 1,586 & $(46 z)$ & 1,660 & $(48 \%)$ \\
\hline 1910 & 176 & $(5 \%)$ & 1,775 & $(50 \%)$ & 1,627 & $(45 \%)$ \\
\hline 1912 & 64 & $(28)$ & 1,821 & $(528)$ & 1,586 & $(46 \%)$ \\
\hline
\end{tabular}


of 15 and 29, were male, and had had little education. ${ }^{6}$ It has proven to be impossible to determine the criteria used to measure the educational level of the prisoners. In the absence of any conflicting evidence, however, it seems reasonable to assume that upon their arrival at the prison, the inmates were asked the amount of schooling they had received and then were placed in the corresponding category. One might assume, for example, that the "Limitedcommon" designation included all prisoners who had received the basics of an education, namely the ability to read and write and do simple mathematics. Any education above this level would have fallen in the "fine-good" category, while anything less would have been termed "illiterate." It is striking to note that at no time during the years covered did the portion of prisoners described as having had a good education rise above 9 percent.

The information regarding the nativity and skill level of the prisoners, in Tables 6 and 7 , respectively, illustrates, to a degree, the changing nature of the state

6 Biennial Report, 1880 , pp. 40,46,49; Biennial Report, 1882, pp. 23, 30, 34; Biennial Report, 1884, pp. 32, 36; Biennial Report, 1886, pp. 34-35; Biennial Report, 1888, pp. 26-27; Biennial Report, 1890, pp. 54-55; Biennial

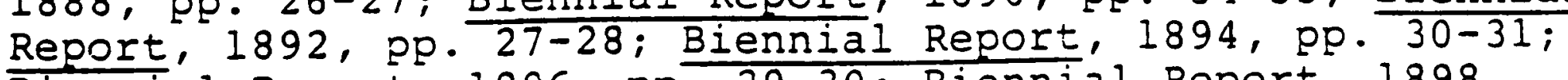
Biennial Report, 1896, pp. 29-30; Biennial Report, 1898, pp. 27-28; Biennial Report, 1900, po. 27-28, 31; Biennial Report, 1902, p. 36; Biennial Report, 1904 , pp. 36-37; Biennial Report, 1906 , pp. 26-27; Biennial Report, 1908, pp. 29-30; Biennial Report, 1910 , pp. 33-34; Annual Report, 1911, pp. 30-31. 
TABLE 6

PERCENTAGE OF PRISON POPULATION BORN IN TEXAS, 1880-1912

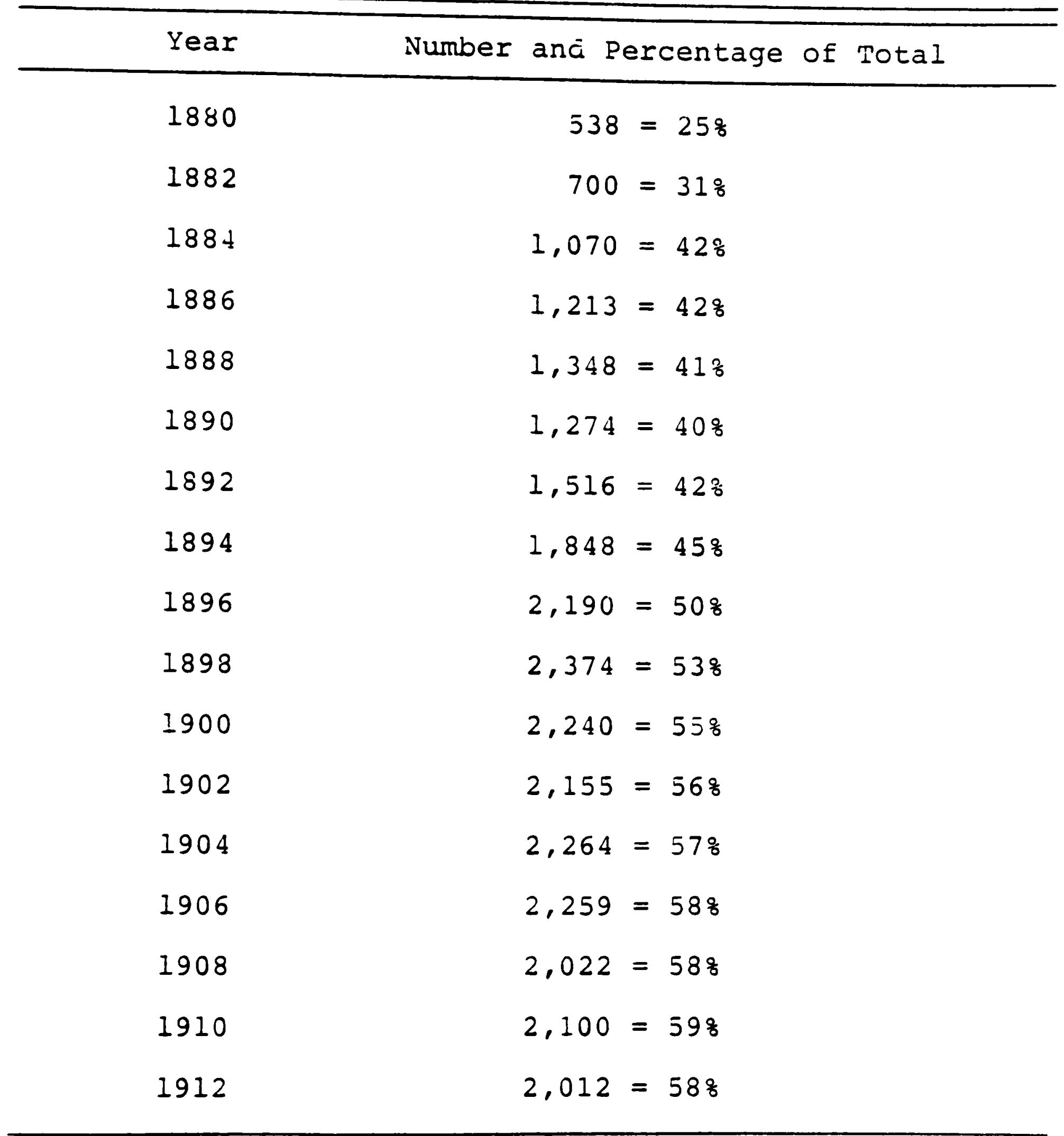


TABLE 7

PERCENTAGE OF PRISON POPULATION LISTED AS HAVING NO TRADE OR OCCUPATION, $1880-1912$

\begin{tabular}{|c|c|c|c|c|}
\hline Year & Number & and Perce & entage of & Total \\
\hline 1880 & & $1,753=$ & $=81.0 \%$ & \\
\hline 1882 & & $1,864=$ & $=81.8 \%$ & \\
\hline 1884 & & $2,150=$ & $=85.0 \%$ & \\
\hline 1886 & & $2,397=$ & $=83.08$ & \\
\hline 1888 & & $2,729=$ & $=82.68$ & \\
\hline 1890 & & $2,546=$ & $=79.6 \%$ & \\
\hline 1892 & & $2,776=$ & $=78.0 \%$ & \\
\hline 1894 & & $3,292=$ & $=79.88$ & \\
\hline 1896 & & $3,585=$ & $=81.0 \%$ & \\
\hline 1898 & & $3,572=$ & $=80.0 \%$ & \\
\hline 1900 & & $3,031=$ & $=73.7 \%$ & \\
\hline 1902 & & $2,708=$ & $=70.0 \%$ & \\
\hline 1904 & & $2,666=$ & $=67.08$ & \\
\hline 1906 & & $2,694=$ & $=69.7 \%$ & \\
\hline 1908 & & $2,376=$ & $=68.58$ & \\
\hline 1910 & & $2,333=$ & $=65.0 \%$ & \\
\hline 1912 & & $2,284=$ & $=66.08$ & \\
\hline
\end{tabular}


population during the late nineteenth century. ${ }^{7}$ Prior to 1896 the majority of state prisoners had been born outside of Texas. Of this majority, most came from the other states of the former Confederacy, particularly Alabama, Arkansas, Louisiana, and Mississippi. Such findings coincide precisely with the immigration pattern into Texas in the years (following the end of the Civil war and Reconstruction. 8 The decline in the number of prisoners having no skill or professional training, Table 7, can be interpreted as a reflection of the changing nature of the Texas economy during the period. The state was moving away from an overwhelmingly agricultural orientation to one that included manufacturing, lumbering, oil processing, and incipient industrialization, all of which required a work force with some degree of specialization. The growing urban centers also demanded a myriad of skills to provide the various services necessary for a city to function. 9 of those

7 Biennial Report, 1880 , pp. 47-48; Biennial Report, 1882, pp. $\frac{\text { Bi-33; Biennial Report, } 1884, p p . \frac{33-34 ;}{31-32 i e n n i a l}}{21-23 ;}$ Report, 1886 , pp. $31-32$; Biennial Report, 1888 , pp. $21-23$; Biennial Report, 1890, pp. 49, 55; Biennial Report, 1892, pp. 23-25; Biennial Report, 1894 , pp. 25-28; Biennial Report, 1896, pp. 25-26; Biennial Report, $1898, \mathrm{pp} \cdot 23-25$; Biennial Report, 1900, pp. 23-25; Biennial Report, 1902, pp. 30-33; Biennial Report, 1904, pp. 29-30,32-33; Biennial Report, 1906, pp. 22-23; Biennial Report, 1908, pp. 24-27; Biennial Report, 1910, Dp. 28-32; Annual Report, 1911, pp. 25-27.

${ }^{8}$ Spratt, Road to Spindletop, p. 228.

${ }^{9}$ Ibid., pp. 277-285. 
inmates possessing skills, barbers, cooks, carpenters, and machinists constituted the largest numbers.

An examination of the major crimes for which prisoners had been convicted, Table 8 , also demonstrates the evolving nature of Texas society. 10 The marked decreases in the number of convictions for cattle and horse theft over the period can be interpreted as an accompaniment to the passing of the comparatively lawless, open-range frontier period of the state's history. Correspondingly, the dramatic increases in penitentiary committals for burglary and forgery can be viewed as characteristic of a more stable, complex society in which a sizable percentage of the population congregated in established towns. Generally, one does not think of burglary, which involves theft via illegal entry into a habitation or place of business, as a serious problem for small, relatively-isolated farmers and ranchers, many of whom likely would not have had items of great value in their homes. Cities and towns, on the other hand, represented some concentration of wealth and

10 Biennial Report, 1880, p. 45; Biennial Report, 1882, pp. 28-29; Biennial Report, 1884, p. 35; Biennial Report 1886, p. 33; Biennial Report, 1888, p. $2 \overline{4 ; \text { Biennial }}$ Report, 1890, p. 52 ; Biennial Report, 1892, p. 26 ; Biennial Report, 1894, p. 29; Biennial Report, 1896, p. 28; $\overline{\text { Biennial }}$ Report, 1898, p. 26; Biennial Report, 1900, p. 26; Biennial

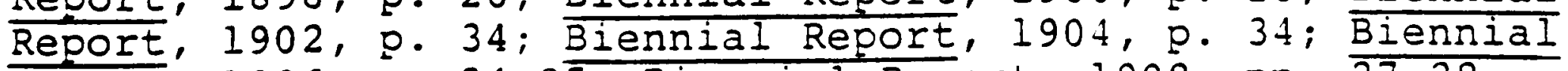
Report, 1906, D. 24-25; Biennial Report, 1908, pp. 27-28; Biennial Report, 1910, p. 32; Annual Report, 1911, p. 29. 


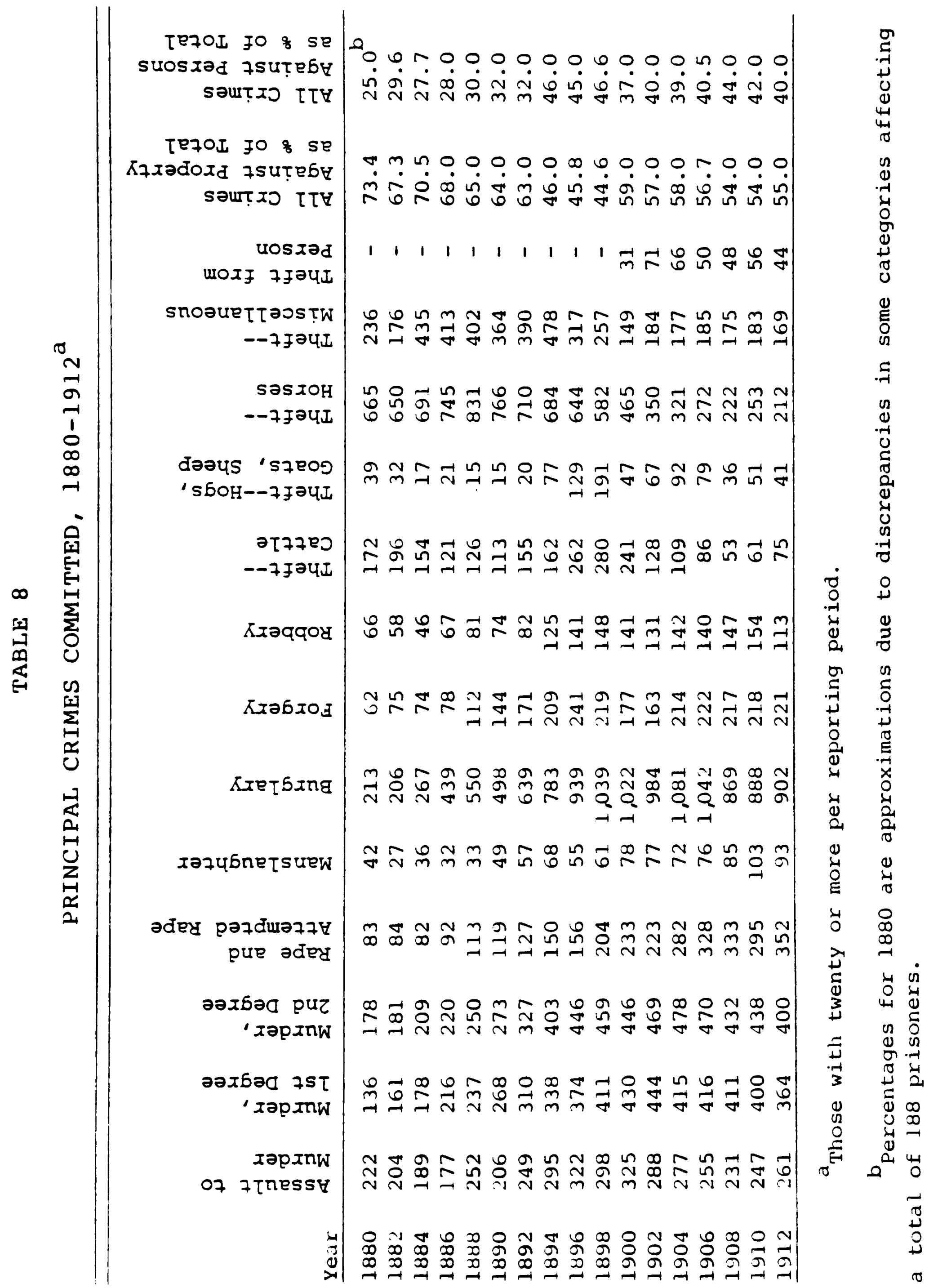


offered to potential thieves a variety of targets as well as opportunities to conceal themselves quickly after the crime. Forgery did not become a significant problem until Texas society reached the point that it made regular, widespread use of written legal and financial instruments.

The information presented in Table 9 showing the terms of confinement appears to contradict statements made by prison officials concerning the feasibility of reforming prisoners by teaching them a trade during their incarceration. 11 It suggests that little reforming of inmates took place while they were in the custody of the state. The percentage of the prison population serving terms of greater than four years duration, 60 percent or more, calls into serious question the assertions by Superintendent Goree and others that it was impractical to teach industrial skills to previously untrained prisoners who were serving relatively short sentences. Such assertions had figured prominently in the state's decision to commit its prison work force to outside farm contract labor at the expense of developing industries within the prisons. It would

11 Biennial Report, 1880, p. 46 ; Biennial Report, 1882, pp. $\frac{\text { 29-30; Biennial Report, } 1884 ; \text { p. 36; Biennial }}{25}$ Report, $1886, \mathrm{p}$. $34 ;$ Biennial Report, $1888, \mathrm{p} . \overline{25 ;} \frac{\mathrm{Bien}}{27}-$

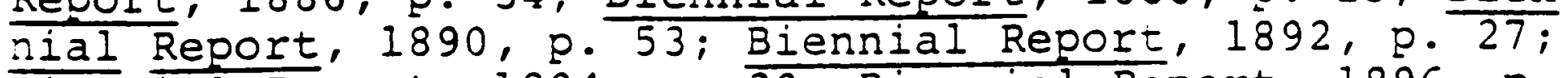
Biennial Report, 1894, p. 30; Biennial Report, 1896, p. 29; Biennial Report, 1898, p. 27; Biennial Report, 1900, p. 27; Biennial Report, 1902 , p. 35; Biennial Report, 1906, p. 25; Biennial Report, 1908 , p. 28; Biennial Report, 1910, p. 33; Annual Report, 1911, p. 30 . 


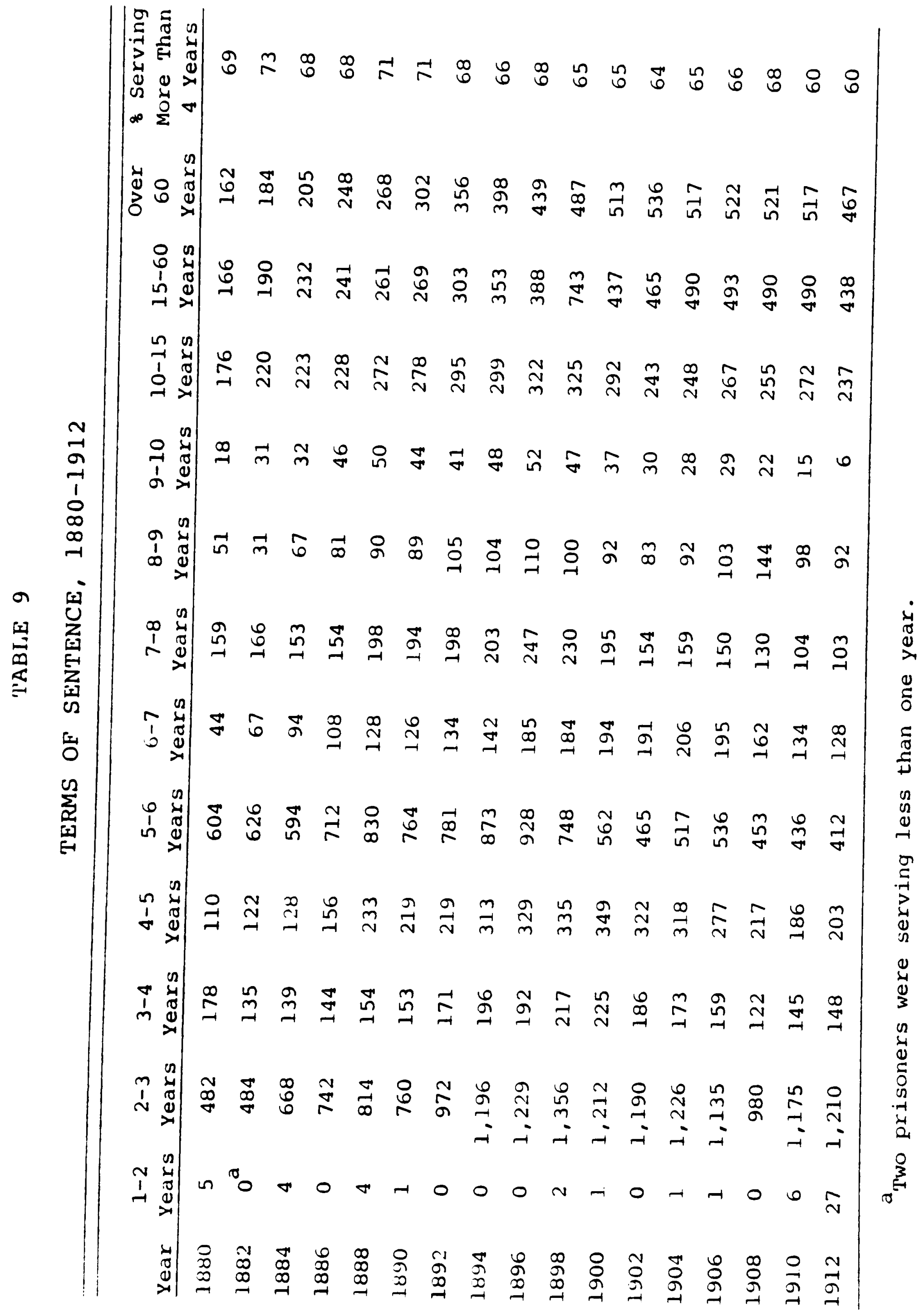


appear that a sentence of four years or more would provide ample time to train any person of average ability to operate the kinds of machinery needed in a prison industry. The fact that such training was not provided when it apparently could have been strengthens the argument that the decision to place the prisoners at outside contract labor derived less from necessity and more from the desire for profit.

The decline in the number of prisoners serving a first-term sentence and the corresponding increase in those confined for a second term or more, Table 10, provides additional evidence that reforming the offender did not command a high priority in the administration of the prison. ${ }^{12}$ Had reform been the preeminent objective of incarceration, one would expect to see fewer second term commitments rather than more. The increases in third and fourth term sentences, beginning in the 1890s, indicates that by the first decade of the twentieth century, the state was on its way to developing a class of people

\section{Biennial Report, 1880, p. 50; Biennial Report,} 1882, p. $36 ;$ Biennial Report, 1884, p. 32; Biennial Report, 1886 , p. 35 ; Biennial Report, 1888 , p. 27; Biennial Report, 1890 , p. 55; Biennial Report, 1892, p. 28; Biennial Report, 1894 , p. 31; Biennial Report, 1896 , p. 30 ; Biennial Report, 1898, p. 28; Biennial Report, 1900 , p. 38; Biennial Report, 1902, p. 37; Biennial Raport, 1904, p. 37 ; Biennial Report, 1906 , p. 27 ; Biennial Report, 1908, p. 30 ; Biennial Report, 1910, p. 34; Annual Report, 1911, p. 31. 
TABLE 10

COMMITMENTS AND RECOMMITMENTS, 1830-1912

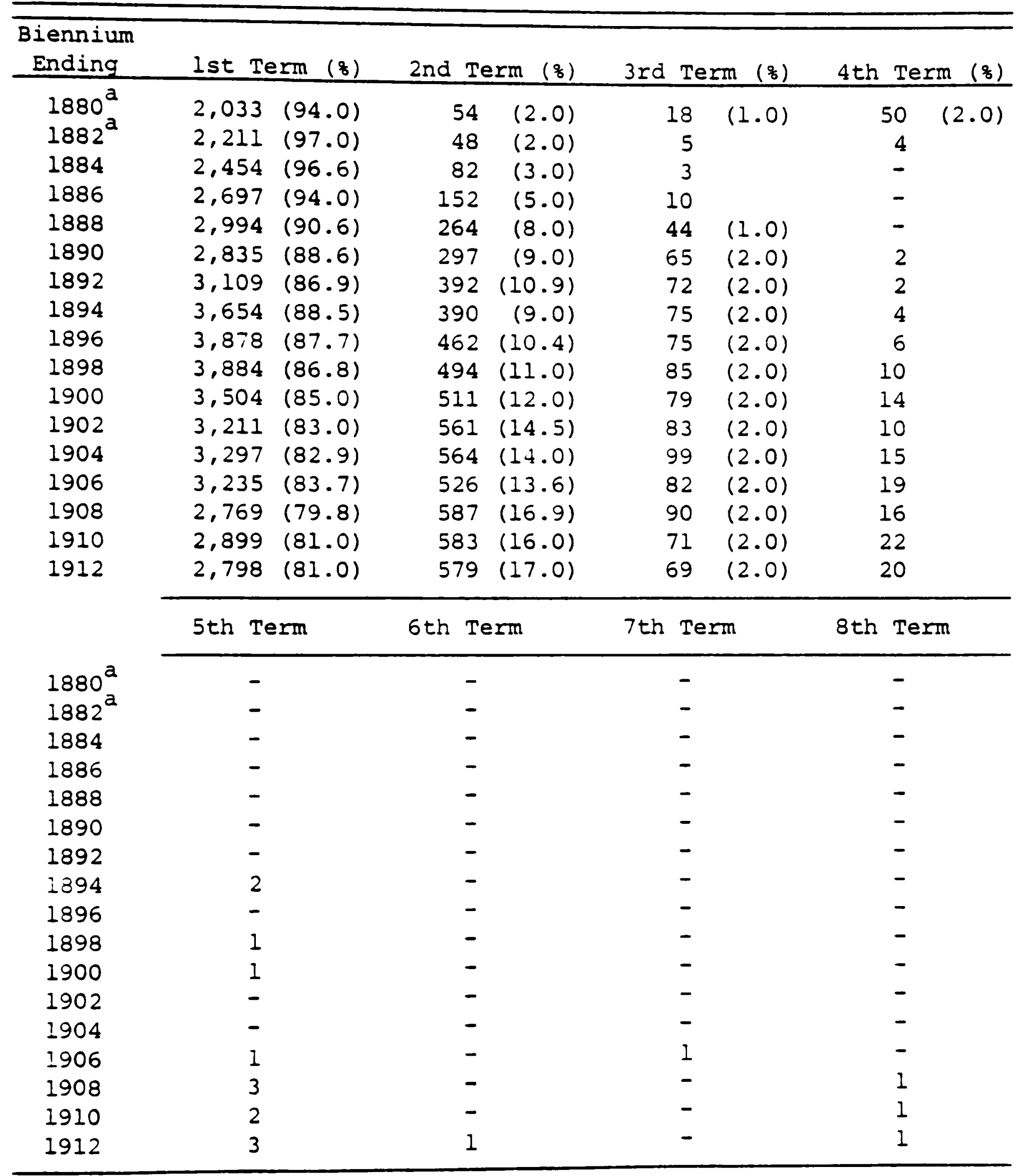

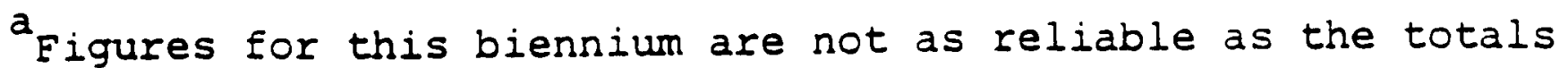
Ecr subsequent years. The keeping of official records was unsatisfactory, especially regarding prior commitments to the Texas prison or confinement in prisons of other states. Accuracy in reporting improved substantially following state resumption of the prisons in 1883. 
committed to a life of crime despite previous confinement in the penitentiary and the threat of future incarceration. The prison was not preparing many of its charges to lead useful, productive lives upon their release. Indeed, in the words of one inmate, the prisons were "a nurse and school" where one began the long-term commitment to criminal activity. 13

The number of escapes and deaths over the period as presented in Table 11, shows few signs of genuine progress. 14 There was a rather marked decline in the number of escapes following resumption of state control in 1883, yet the figures remained far above the level one might have thought acceptable. The number of deaths, perhaps the measure that spoke most forcefully of the manner in which prisoners were treated, did not decrease substantially until the biennium ending in 1910. One can assume that the legislative investigation of 1909-1910 had a positive effect in reducing the prisoner death rate even

$13 \mathrm{~J}$. L. Wilkinson, The Trans-Cedar Lynching and the Texas Penitentiary (Dallas: Johnston Printing and Advertising Company, n.d.), p. 101.

I4 Biennial Report, 1880 , pp. 38, 41; Biennial

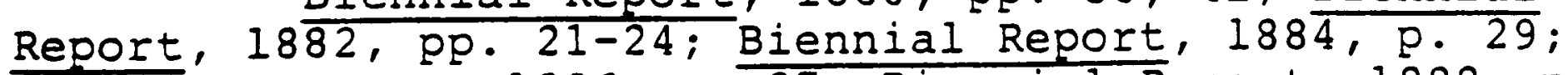
Biennial Report, 1886, p. 37; Biennial Report, 1888, p. 26; Biennial Report, 1890, pp. 46, 59; Biennial Report, 1892, p. 19; Biennial Report, 1894, p. 35; Biennial Report, 1896, p. 21 ; Biennial Report, 1898 , pp. 27,32 ; Biennial Report, 1900, p. 27; Biennial Report, 1902, p. 36 ; Biennial Report, 1904 , p. 36 ; Biennial Report, 1906 , pp. 26,31 ; Biennial Report, 1908, p. 29; Biennial Report, 1910, p. $3 \overline{3 ;}$ Annual Report, 1911, ?p. $30, \frac{35}{35}$ 
TABLE 11

NUMBER OF ESCAPES AND DEATHS PER BIENNIUM, $1880-1912$

\begin{tabular}{|c|c|c|c|c|c|c|}
\hline $\begin{array}{l}\text { Biennium } \\
\text { Ending }\end{array}$ & Escapes & - & $\begin{array}{l}\text { Percent of } \\
\text { Average Annual } \\
\text { Population of } \\
\text { the Biennium }\end{array}$ & Deaths & - & $\begin{array}{l}\text { Percent of } \\
\text { Average Annual } \\
\text { Population of } \\
\text { the Biennium }\end{array}$ \\
\hline 1880 & 366 & - & 9 & 256 & - & 7 \\
\hline 1882 & 397 & - & 9 & 205 & - & 5 \\
\hline 1884 & 273 & - & 6 & 206 & - & 4 \\
\hline 1886 & 236 & - & 4 & 221 & - & 4 \\
\hline 1888 & 115 & - & 4 & 223 & - & 4 \\
\hline 1890 & 166 & - & 3 & 183 & - & 3 \\
\hline 1892 & 130 & - & 2 & 114 & - & 2 \\
\hline 1894 & 166 & - & 2 & 150 & - & 2 \\
\hline 1896 & 164 & - & 2 & 217 & - & 4 \\
\hline 1898 & 133 & - & 2 & 196 & - & 2 \\
\hline 1900 & 189 & - & 2 & 269 & - & 3 \\
\hline 1902 & 152 & - & 2 & 164 & - & 2 \\
\hline 1904 & 129 & - & 3 & 173 & - & 2 \\
\hline 1906 & 131 & - & 3 & 120 & - & 3 \\
\hline 1908 & 177 & - & 2 & 161 & - & 2 \\
\hline 1910 & 175 & - & 2 & 90 & - & 1 \\
\hline 1912 & 125 & - & 2 & 50 & - & 1 \\
\hline
\end{tabular}

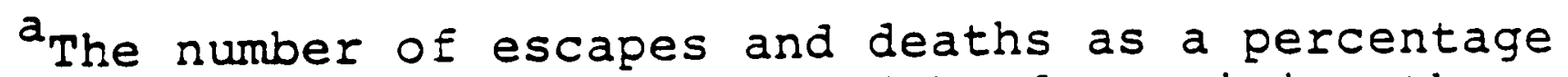
of the prison population was figured by determining the average annual population of the biennium and dividing that number into one-half the total number of escapes and deaths for the biennium. The results are rounded off to the nearest percentage point. 
though the figures were still too high at the end of the period under study, 1912.

For the average inmate, the trip to the penitentiary began following conviction for a felony charge in one of the counties of the state. Upon completion of the court's term, the prisoners were turned over to the contractor hired to transport the guilty to the prison. Generally, prisoners traveled on public carriers, frequently by train, under careful guard throughout the trip. They were chained together by neck collars to make escape a virtual impossibility. ${ }^{15}$

One former prisoner, describing his trip to the Rusk facility, wrote that he and others recently.convicted left Kaufman County by train in the care of the contractor. The group arrived in Tyler "about 10 o'clock at night," after a day during which they had not been fed. The prisoners spent the night "on the cold, sandy floor without covering of any kind. . . ." The next morning, still without having eaten, they were "loaded on a frosty flat car" for the last part of the trip. 16

Upon arrival in Rusk, the group of prisoners walked the mile and a half to the prison where all their

${ }^{15}$ Charles C. Campbell, Hell Exploded, An Exposition of Barbarous Cruelty and prison Horrors (n.p., 1900), 20. 12-13. ${ }^{16}$ Ibid. 
belongings were taken from them without receipt by the gate guard. They then marched to an office inside the walls where the neck collars were removed and a "convict clerk" questioned them as to their "age, nationality, occupation, habits, and the like." Once this was completed, a guard forced them to march "lock step" to a "wash shed" where they were issued the blue-striped prison garments. 17

The group stopped next at the dining hall, a room wherein "rows and rows of wooden desk-like tables stood with their tin plates and cups." Each of the cups contained "a few swallows of warm, greasy water," that was augmented with "several pans of cold corn bread and raw, fat bacon." In spite of the unappetizing appearance of the food, the men ate heartily as it was the first they had been given in thirty-six hours. 18

Following the meal, the new arrivals marched to the barber shop where all beards were shaved off. The barbers also cut the men's hair so that it resembled a "winding stairway around the head. . . ." Thus dressed, fed, and coiffed, the prisoners were ready to proceed to

17Ibid., pp. 13-14. The "lockstep" requires the prisoners to form a straight line and walk, one behind the other, with the right hand on the shoulder of the man in front.

${ }^{18}$ Ibid., pp. 14-15. 
their respective work assignments. 19

All evidence indicates that the desire for profits formed the major consideration in determining the type of work the individual prisoners would do. The private contracting parties wanted healthy, able-bodied men in return for their labor payments to the state. Therefore, prison officials separated the prisoners accordingly and retained in the walls those individuals whose physical condition would not bear up to the strenuous working regimen in the outside camps. 20

Had they been given the choice, the inmates would have preferred to remain in the walls. In addition to a work load that was relatively lighter, better living conditions also prevailed. Moreover, only inside the prisons could the inmates receive educational opportunities, religious instruction, use of a library, and medical care. To a significant degree, prisoners in the contract camps lived outside the pale of even the most minimal reformatory efforts.

Despite those provisions in the 1883 rules and

19 Ibid.

20 As far as could be determined, there seems to have been little regularity in making assignments to specific camps. Generally, the black prisoners were sent to the farms in the river bottoms, including the sugar cane olantations. White and Mexican prisoners usually worked the other farms, the railroad construction crews, and the coal mine force. Biennial Report, $1886, \mathrm{p} .19$. 
regulations which sought to provide for better care of the prisoners in the outside camps, life away from the prisons remained almost unendurable. Sergeants and guards in the camps, although employed and paid by the state, succumbed frequently to the economic blandishments of the contractors who promised generous rewards to the state personnel in return for increases in production. Generally, the greater production could be accomplished only by working the prisoners beyond all reasonable limits. Legislative investigations in 1902 and 1909 attested to the failure of state officials to manage the prisons and supervise the camps in accordance with the established policies. 21

The 1902 investigation by members of the legislature resulted from Senate Joint Resolution Number 1, passed in late October, 1901, during the second called session of the Twenty-seventh Legislature. The resolution created the State Investigating Committee and charged the body with the responsibility of investigating "the various departments of the State government. . . " Committee members were to gather information on all state agencies and prepare recommendations for the governor to present before

21 Report and Proceedings of the Senate Investigating Committee, Provided for in Senate Joint Resolution No. 1, Passed at the Second Called Session, Twenty-seventh Legislature (Austin: Von Boeckmann, Schutze and Company, State Printers, 1902), p. 325; Report of the Penitentiary Investigating Committee, 1910, pp. 7-29. 
subsequent sessions of the state lawmakers. 22

The committee tendered its report to the governor in mid-June, 1902, following "one hundred and twenty days of incessant labor. . . ." It is impossible to determine the amount of time the committee spent with each agency. Given the size and scope of the task, however, plus the fact that the committee consisted of only five members, one can assume that the examination was perforce superficial. Further evidence that the 1902 committee did not get a complete picture of prison conditions came from one of the prisoners who, upon his release from custody several years later, wrote that prisoners were often reluctant to speak openly with the investigators for fear of reprisals by the guards once the committee had departed. 23

Despite the limitations, the investigators managed to see enough of prison life to convince them of the venality inherent in the policy of hiring out prisoners to private individuais. They considered leasing to be "a disgrace to the state" and so "harsh, cruel, [and] inhumane" as to be "unworthy of an enlightened people."

22 Legislative Investigation, 1902, po. 3-5.

23 Ibid., pp. 3-4; Henry Tomlin, Henry Tomlin, The Man who Fought the Brutality and Oppression of the Ring in the State of Texas for Eighteen Years, and Won (n.p.: n.P., 1906), PP. 121-124, 146 . 
When men are shot down like dogs and are worked until they drop dead under this system, the people of Texas cannot hope to escape responsibility for these wrongs, and we believe that if the present condition of things were known to them, and they could be made to realize it, they would bring such pressure to bear upon the next Texas Legislature that these evils would be stopped. 24

The investigating committee found evidence that officers in the outside camps frequently accepted extra payment from the contractors to coerce greater production out of the prisoners. The sense of the committee held such practices to be "wrong in principle." The state paid the men a "fair salary," and "an employee of the State ought not to receive additional pay from outside parties." 25 $\Gamma$

The only tangible result of the 1902 investigation appeared in legislation passed in 1903. Lawmakers prohibited penitentiary employees from accepting or receiving "any salary or other compensation from any person or corporation hiring or otherwise employing state convicts." Penalties for violators included dismissal from state employment, a fine of not less than $\$ 25$ nor more than $\$ 100$, and confinement in the county jail for at least one month but not longer than one year. 26

\footnotetext{
24 Legislative Investigation, 1902, pp. 323-324. 25 Ibid., p. 325 .

${ }^{26}$ General Laws of the State of Texas Passed at the Regular Session of the Twenty-eighth Legislature Convened at the City of Austin, January 13, 1903, and Adjourned April 1, 1903 (Austin: Von Boeckmann-Jones Company, State Printers, 1903), pp. 161-162.
} 
In contrast to the 1902 investigation, the one in 1909 proved better organized so that a more accurate picture of prison conditions emerged. For one thing, the 1909 committee, made up of nine members, five from the house and four from the senate, spent the better part of four months investigating only the prison. Having more time, committee members heard testimony from a greater number of sources and gathered corroborative evidence to confirm what they had been told. In addition, the fact that the press publicized daily the findings of the committee intimidated into inaction those prison officials who might have been tempted otherwise to threaten and coerce inmates into silence. 27 One former prisoner noted that the 1909 investigation, unlike previous efforts, constituted a genuine search to "go to the bottom of things." 28 The investigation began in Austin on July 15, 1909, and the final report was forwarded to Governor Campbell on November 24 of the same year. ${ }^{29}$ By way of general observations, the committee reported that the rules and regulations adopted for the government and discipline of state prisoners had "in many important respects been almost

27 Wilkinson, Trans-Cedar Lynching, pp. $146-148$. 28 Ibid.

${ }^{29}$ Legislative Investigation, 1910, pp. 1-7; Members of the Legislature of the State of Texas, 1846 to 1939 (n.P.: N.P., 1939), PD. 221-228. 
wholly ignored." Few of the sergeants and guards had any familiarity with the rules, "either as to their own duties or the rules governing the conduct of convicts." Indeed, in some instances, the committee found sergeants who disobeyed the regulations willfully and "displayed no apparent inclination" to change. 30

The most egregious lapses from accepted policy occurred in the punishment meted out to inmates in the contract camps where whipping was the preferred method of enforcing discipline. The milder forms of punishment, such as deprivation of privileges or confinement in the dark cell, were seldom used, if ever. The committee found prisoners, "in a great many instances," whose bodies had been scarred badly by sergeants using whips constructed according to whatever "their fancy or brutal inclinations might dictate." Seldom did the officials in the outside camps seek to follow procedures and secure written permission before whipping a prisoner. ${ }^{31}$

The committee based its findings regarding excessive and unauthorized punishment upon the sworn testimony of prisoners who either had been beaten themselves or had

${ }^{30}$ Lesislative Investigation, 1910, p. 7.

${ }^{31}$ Ibid., pp. 7-8. The committee report described a typical leather whipping strap as being "from four feet to more than five feet in length and from three to four inches in width. . . " Legislative Investigation, 1910, ?. 7 . 
witnessed the beating of others. During the initial stages of the investigation, the committee members expressed skepticism over the veracity of convicted felons. As the hearings progressed, however, the doubts melted away when the same stories were recounted by prisoners in different camps with no opportunities for collusion or for knowing what previous testimony had been.

A twenty-nine year old Fort Worth man, H. W. Johnson, who was serving a ten-year sentence for burglary and theft proved to be one of the most informative witnesses. Johnson had been convicted in February, 1902, and, since his entry into the prison system, had been moved a total of fifty-four times depending on the wishes of prison officials. He had spent time in both Huntsville and Rusk, both of which he preferred to the outside camps.

Well, I have nothing to say against the Walls; I have been treated fairly right here in the Walls, except the guards get it in for a convict in here and he [convict] is transferred out on to a farm, and I call those farms hard, as hard as it can be anywhere. I have been pretty near all over the U.S. and I have seen a good deal, and I don't think I have seen anything that would compare with some of those farms in the State of Texas. . . .32

Johnson revealed that he had been whipped several times during his period of confinement. On one occasion, he had received twenty-seven licks for not pulling enough cotton. Although he was picking three-hundred pounds a

32 Ibid., pp. 243-244. 
day on average, the sergeant said that that was not enough. Prior to being whipped, he was stripped of his clothing and laid on the floor where other prisoners held his feet, arms, and head. 33

In addition to the whippings he had endured, Johnson stated that he had seen at least 800 other men so disciplined since he had been in the prison. When the committee expressed surprise that the figure was so high, he explained that a good many of the whippings administered had not been reported on the record books. If a guard lost his temper or for any other reason decided suddenly to whip a prisoner, he did it and did not bother to report it. 34 When asked by the committee if he had ever seen the guards kill a man, Johnson replied in the affirmative and described the incidents. In one case, a prisoner on the Whatley and Herring farm had asked the guard for permission to "get on a job," that is relieve himself. The guard gave his permission but as the man walked away and prepared to lower his trousers, the guard shot and killed him. According to the testimony, the man had not attempted to run and the guard had said nothing in the way of a warning prior to the killing. 35

$$
\begin{aligned}
& 33 \text { Ibid., pp. } 246-247 . \\
& 34 \text { Ibid. } \\
& 35 \text { Ibid., pp. 250-251. }
\end{aligned}
$$


The other two deaths related by Johnson came as a result of whippings. A Mexican prisoner named Antonio and "an Irishman" named Mike Dunn, both working on the Whatley and Herring farm, received such severe whippings that they died a few hours later. The next morning they were buried on the farm after the guard forced another of the prisoners to do a dance on one of the coffins. No inquests were held in either of the killings and the cause of death was listed as sunstroke. 36

In concluding his testimony, Johnson detailed other examples of the seemingly wanton conduct of guards. He described instances in which inmates had died after having been dragged through the fields by guards mounted on horseback. He told of prisoners being forced to work when they were sick and unable to move and, to demonstrate the degree to which prisoners existed at the perverted whim of their keepers, told of an inmate who had been forced to eat his own feces simply because the guard had instructed him to do so. 37

The testimony given by Johnson proved typical of much that the investigating committee heard. As the investigation progressed and the prisoners became convinced that the committee would take steps to protect them, they

$$
\begin{aligned}
& { }^{36} \text { Ibid., pp. 252-254. } \\
& { }^{37} \text { Ibid., pp. } 243-257 .
\end{aligned}
$$


appeared to speak freely of the conditions under which they had been forced to live. One black prisoner, John Carr, described his treatment after recapture following an unsuccessful attempt to escape from the Harlem state farm. He stated that the guard who caught him knocked him down with the butt end of a pistol, then turned the dogs loose on him. Upon his return to camp, Carr also received a severe whipping. He mentioned that it was not unusual for the guards to turn the dogs on recaptured prisoners and that he "never saw a man come back here with all his clothes on." 38

Prisoner Eugene Lee, convicted in 1898 of murder in Ellis County, told the committee that he had seen close to two hundred men whipped since he had been in the Texas prison system. On one occasion, Lee himself had received seventy-one licks for failure to perform his work in a manner satisfactory to the sergeant. In the course of the whipping, many of the blows fell on Lee's lower back, damaging his kidneys. As a result, he passed blood for several days and frequently lost control of his bladder. 39 Lee also described for the committee the punishment known as "hanging them in the window." Prisoners were forced to grab the bars high up in the window, then

${ }^{38}$ Ibid., pp. 297-300.
${ }^{39}$ Ibid., pp. $285-292$. 
pull their feet as close to the hands as possible and hang there holding their entire weight. When they fell from exhaustion, usually after five to ten minutes, they had to repeat the ordeal. Lee recounted an instance in which a prisoner named Oscar Walker was hanging in the window when the sergeant came into the room. The sergeant, a man named Mac Williamson, was "2/3 drunk." According to Lee, williamson had the prisoner taken down from the window and whipped him a total of eighteen licks. 40

At one point in the proceedings, the committee questioned the Reverend Jake Hodges, the former chaplain of the Huntsville unit. Hodges testified concerning two cases that affected him particularly. In one incident, a prisoner died as a result of excessive punishment by prison personnel. The other case concerned a young man who mutilated himself to escape the arduous work routine of the prison.

According to Hodges, a fifty-four year old prisoner named Foster had been sent to the Huntsville unit hospital to recover from a severe beating he had received on the Whatley-Herring farm. In the words of Foster, as related by Hodges,

Oh, they have nearly killed me; they have whipped me on the farm; I was too old and couldn't keep up.. . with the younger men and they stripped my britches

$$
40 \text { Ibid. }
$$


- - off and whipped me and then sprinkled sand on me and whipped me again and then made me climb a tree that was covered with ants and they got all over me . . they bit me all over.

Foster died approximately one week after relating his story to the chaplain. Hodges told the committee that the sergeant who had whipped Foster had been discharged by Whatley, one of the owners of the farm, but had been hired subsequently on another contract farm in another part of the state. As far as Hodges knew, the sergeant was still in state employment at the time the committee was making its investigation. 41

The other incident related by Hodges involved a young man named Oscar Peterson, described by the chaplain as having been "not very strong mentally." Peterson had been serving his time in the Huntsville unit, but found himself scheduled to be sent to one of the outside farms. The prospect of living on the farm so terrified him that he went to one of the prison shops and cut off two of his fingers in a planing saw, thus insuring that he would remain in Huntsville. As soon as the wounds had healed, Peterson had been whipped until he lost consciousness. According to Hodges, "it looked as if.. . the lash was turned edgeways and had cut quite a gash. . on his back. " 42

$$
\begin{aligned}
& 41 \text { Ibid., pp. 204-206, } 585 . \\
& 42_{\text {Ibid., pp. 208-208, 282-283. }}
\end{aligned}
$$


Hodges identified the man who had whipped Peterson as Chaptain R. H. Coleman, the assistant superintendent at Huntsville. When confronted with the testimony against him, Coleman replied that indeed he had whipped Peterson and that he had done so with the approval of the prison superintendent. In Coleman's view, cutting off one's fingers to avoid work was a "violation of the rules," and, "I mean to convey the idea that when a man violates the rules and knows he is violating them at the time to whip him for it."43 Evidently, since Coleman had requested and received approval to whip Peterson, his actions complied fully with established prison procedures.

By the time the committee had visited several of the camps and had heard all the testimony from the prisoners, the individual legislators might have become so inured to the continuing evidence of outrages that nothing would have surprised them or moved them very deeply. Such was not the case, however. At one camp visited, new evidence appears to have offended profoundly every person who heard it.

On the afternoon of November 12, 1909, at the Clemens state farm, committee members discovered evidence of prisoner mistreatment unlike anything previously encountered. Andrew walker, a prisoner from Tarrant County, 
told the committee that approximately eight months prior to the investigation, Captain R. W. Grace, the assistant sergeant at the camp, had discovered two prisoners, "playing man and wife. . . " Grace had disciplined the two men by whipping them and then forcing them to perform the act of sodomy before the other inmates in the camp. Several other prisoners supported Walker's testimony, including one of the men involved in the affair who had been ordered to humiliate himself even further by telling the other inmates how much he had enjoyed the sexual act with the other man. 44

The shocking revelations of Walker and the other prisoners in the camp reinforced even further to the incredulous members of the committee the realization that the authority of guards and sergeants over the inmates was total and absolute. State prisoners existed at the caprice of an arbitrary power that recognized few if any restraints. The nature and degree of punishment seemingly was limited only by the imagination of those whose job it was to see that the prisoners received proper care.

Despite all the testimony describing the many acts of brutality and cruelty perpetrated by the sergeants and guards, it appears that none of the state personnel was punished for their actions. Rather late in the

${ }^{44}$ Ibid., pp. $72,916-930$. 
investigation, and perhaps as a reaction to public outrage at newspaper disclosures of prison conditions, Governor Campbell asked the committee to furnish him with the names of anyone guilty of breaking prison rules. Specifically, the governor wanted,

- $\cdot$ the name of any officer, sergeant, guard, or other person now in the employ of the penitentiary system who has been found guilty of any violation of the law or mistreatment of convicts since January 15, 1907, the beginning of the present administration... .

Campbell expressed no interest in anything that might have happened prior to his assumption of office. 45

The committee responded by placing the matter back in the governor's hands for any action. After the final report of the investigation had been made public, the committee wrote Campbell expressing its belief that the legislation creating the investigating body did not empower it "to pass upon the guilt or innocence of any man. . . " Since Campbell had a copy of the final report, he could read the testimony for himself and "determine whether there had been any violations of the law by your appointees in the penitentiary service. . . " 46 There is no indication the governor acted on the evidence of mistreatment unearthed by the investigating committee.

\footnotetext{
45 Ibid., p. 25 .

46 Ibid.
} 
In a sense, the manner in which Campbell phrased his request to the committee suggests his motives were more political than genuinely inquisitive. By limiting his inquiry to his administration, the governor implied that he bore no responsibility for anything that might have happened under earlier chief executives. To a degree, he was correct and yet, the very fact that he had appointed many of the prison officials in the period after January, 1907 virtually ensured that he would take no action against them. To have done so would have cast suspicion on his leadership and, to a degree at least, discredited his administration.

In addition to examining the manner in which prisoners were disciplined, the investigating committee sought to learn the conditions under which the prisoners lived and labored. Inmates were asked to describe the work they did, the quality and quantity of food they received, and the manner in which they were clothed and housed. The findings demonstrated that while conditions in the Huntsville and Rusk units were adequate, prisoners in the outside camps did not receive care that even approached the minimum contemplated by the regulations.

Prisoner Sam Tubb described for the committee a typical day's meals in Huntsville. For breakfast, the prisoners received a slice of bread, boiled meat, and molasses syrup. Lunch consisted of bacon and bread, a 
few vegetables, coffee and milk, although the milk was often sour. For dinner, there was rice, boiled meat or bacon, beans and, usually, corn bread. All meat scraps left after a meal were collected and served in a different form later. Tubb pronounced himself pleased with the food he was given and believed it to be "better than most of the farmers get on the outside." The only complaints he made concerned the heat and the numerous mosquitoes that bothered the inmates. 47

Another Huntsville prisoner, German-born John Lenz, confirmed much of Tubb's testimony, saying he had no major complaints as to the care and treatment in the main prison. Lenz did remark that although he received a sufficient quantity of food, the quality was not always such as he would have preferred. The bread was often "kinder musty and - . I don't know, it don't smell good, don't taste good." 48

Before being transferred to Huntsville, Lenz had worked on the Clemens and Imperial state farms and on the Ellis contract farm. When asked to compare life on the farms with what he had experienced in the walls, he replied that there was as much difference as "day and night." He remarked that on the Imperial state farm, the prisoners

${ }^{47}$ Ibid., pp. $275-276$.

${ }^{48}$ Ibid., pp. 222-224. 
were fed very little and the food they did receive was inedible. "I wouldn't feed a dog like it. I would give them more and better." 49

When asked to elaborate on his remarks about the Imperial farm, Lenz stated that the men awoke before dawn and for breakfast were given two biscuits that "never got done--raw dough and molded," plus one-half inch of coffee if they were lucky and could fight to get it. They had to run the "two or three miles" from the prison house to the work site where they were kept at their labors "until the stars were shining down." For lunch, which was eaten out in the fields in the turn rows, the men had a little meat, corn bread that was "cold and hard," and black-eyed peas, also "cold and hard." The evening meal was a repeat of lunch. On some days the prisoners received no meat at all and no coffee, except that made from "little turnip greens cooked with black water," taken directly from "the field where it gathered. . . ." 50

The men were allowed to bathe in groups of eight or ten once a week, on Saturday nights, in a "great big tank dug in the ground and bricked out. . . ." The water was partly heated. They received no changes of underwear or socks but were given a change of outer clothing once a

$$
\begin{aligned}
& 49 \text { Ibid., pp. } 224-225 . \\
& { }^{50} \text { Ibid., p. } 225 .
\end{aligned}
$$


week. Most of the prisoners, however, chose not to change clothes regularly since very often the ones they were given were still dirty. As a result, most of the men were louseridden. 51

The investigating committee described the main building on the Imperial farm as being 60 feet long by 25 feet wide. It was unscreened and housed 74 men. There was about the building "a very strong, obnoxious, offensive odor. . . " Connected to the main building was the dining room, also unscreened, which measured 60 feet by 14 feet. The bathing trough was located in the dining room. 52

The bedding provided for the men remained filthy because it was never changed. The men often did not bother to clean the mud off their clothes before falling into bed. Lice and bedbugs infested the beds while cockroaches ran everywhere. 53

In all the essential details, the facilities and conditions which prevailed at the Imperial farm appeared typical of the outside camps. Fong, arduous workdays, poor quality food, and filthy, unsanitary living quarters were standard,j Completely unheated bathing water on most

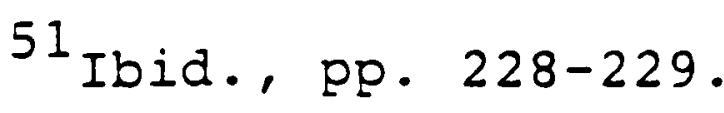

52 Ibid., p. 879.

53 Ibid., p. 230 .
} 
of the farms, even during the winter, represented the only noteworthy difference. Given the conditions under which they had to live on the farms, most prisoners preferred to serve their time in Huntsville or Rusk. In the words of a Huntsville inmate, "Well, gentlemen, put me twentyfive solid years; I take that before I take six months on the farm. Give me twenty years solid here before I would get six months on the farm." 54

Most of the outside camps, like the Imperial farm, housed male prisoners performing agricultural labor. Two camps that did not conform to this model also existed, the Eastham women's farm and the Calvert coal mining force. Because of the unique nature of these two camps, they merit examination in some detail.

At the Eastham share farm in Houston County the work force was divided into two camps. Camp number two housed the women prisoners who totalled approximately sixty. Available evidence does not specify the racial composition of the female force but the testimony taken by the committee leads to the conclusion that black women were in the majority. By the labor division on the farm the white women worked inside the buildings while the black women toiled in the fields. 55

54 Ibid.

55 Ibid., pp. 15, 35, 546. 
Although women formed the work force in the camp, men provided all the guards. 56 This situation had given rise to charges of improper conduct between the two sexes. Most of the committee's questions, therefore, sought to ascertain the truth of such assertions.

Of the nine women who testified before the committee, only two were white. Both of them stated that they had been treated satisfactorily while in prison. None of the guards had ever made improper remarks or suggestions to them. The seven black women who testified told a different story. 57

One of the witnesses reported that the women were forced to work in the fields despite any physical infirmity they might be suffering. The onset of the menstrual cycle did not excuse them from work. If whipping became necessary, the guards tied the prisoners hands, took off their clothing, and whipped them "on the naked meat," in front of other guards. The prisoners recounted a number of instances wherein the guards came for the prisoners at night and used them for their pleasure. Sometimes the women were paid for their services while, on other occasions, the guards promised to use their influence to secure a pardon or early release. 58

$$
\begin{aligned}
& { }^{56} \text { Ibid., p. } 575 . \quad 57 \text { Ibid., pp. 544-547. } \\
& { }^{58} \text { Ibid., pp. } 548-562,572 .
\end{aligned}
$$


One black prisoner testified that she had been in prison eight years when she gave birth to a child. The father, a white guard named Jerry Bowden, was the son of the man who was in charge of the camp at the time. The witness never revealed the father's identity to any of the guards for fear that she would have been killed. 59 Actually the shameful manner in which the female prisoners were treated had been made known to state officials prior to the visit by the investigating committee. As early as October, 1907, a former inmate of the women's camp had written a lengthy letter to Governor Campbell explaining in some detail the conditions under which the women lived. The letter spoke of the hard work the women had to do, the abusive language used by the guards, the filthy quarters in which prisoners lived, and told of pregnant women who, being without adequate medical care, had delivered their babies in the fields where they worked. The testimony before the committee confirmed the stories related by the former prisoner. 60

The conditions which prevailed at the coal mining camp near Calvert, Texas also differed from anything

\section{${ }^{59}$ Ibid., pp. 564-567.}

${ }^{60}$ Lula Sanders to Thomas M. Campbell, October 2 , 1907, Letters Received, Thomas M. Campbell Papers, Texas State Archives and Library, Austin, Texas; Legislative Investigation, 1910, pp. 514-577. 
encountered elsewhere by the investigating committee. The extreme filth and the severe nature of the work exceeded by a considerable degree anything the committee members might have expected. The legislators were so shocked by what they saw that they called for the immediate closing of the camp. 61

The committee described the main prison building at Calvert as being "extremely filthy." It measured $84 \frac{1}{2}$ feet long by $35 \frac{1}{2}$ feet wide. The dining room of the camp was slightly smaller than the main building. The 105 men assigned to the camp worked underground in the mine where water stood all the time. Every man was required to mine seven tons of coal per day. The men faced whipping if they did not make their quota. Living and working conditions at Calvert were so physically debilitating that at one point 50 percent of the men were hospitalized. 62

Representative Bowman described one of the Calvert Erisoners who appeared before the committee:

He has on no underwear. Just two top pieces. Coat or shirt may have been washed a couple of years ago. Has no button nor button holes either in front or on the sleeves. Greasy black in appearance. All stripes obliterated by reason of the dirty grease, etc. Trousers black in appearance and dirty, greasy and smutty, without any buttons. Fastened around the

$$
\begin{aligned}
& 61 \text { Legislative Investigation, } 1910, \text { pp. 12-13. } \\
& 62 \text { Ibid., pp. 607-609. }
\end{aligned}
$$


waist with a horseshoe nail, without belt or suspenders. Too large in the waist by six or eight inches or more. Sleeves of the shirt without buttons and are ragged. Shirt fastened in front with a match. Both shirt and trousers decidedly filthy. 63

A bit later, Bowman commented on the condition of the feet of a prisoner who worked in the mine.

They are very dirty and have scales on them like an alligator's foot. They are wrinkled, scaly and cracked and have the appearance of being painted with iodine and the bottom is as black as a negro's foot. They are brown, parched and shriveled, the skin having the appearance of dead skin and are red up to and above the ankle. 64

The overwhelming evidence of prisoner mistreatment naturally called into question the quality of state inspection that went on in the camps. When the committee questioned the two inspectors, the interrogation revealed serious weaknesses in this area of prison administration. Sam Hawkins and J. G. Barbee, both appointed by Governor Campbell, had been serving as inspectors since February, 1907. They were paid $\$ 2,000$ per year, plus traveling expenses. Hawkins had responsibility for the outside camps in the northern part of the state while Barbee covered those in the south. 65

Hawkins explained that there were eleven farms in his district and that he visited each of them once a month.

$$
\begin{aligned}
& 63 \text { Ibid., p. } 613 . \\
& 64 \text { Ibid., p. } 616 . \\
& 65 \text { Ibid., pp. } 319-329,403-418,428 \text {; Lodging was }
\end{aligned}
$$
not included in the traveling expenses. 
His duties, as he saw them, were to "superintend those camps - . in the absence of the superintendent." He said that on a typical inspection trip he looked into all aspects of camp life and spoke privately with each prisoner. Hawkins' description of his visits must have taxed the credibility of some committee members when, in speaking of a recently-completed trip to the Burleson farm, he explained that he had been in the camp from noon until 5:00 P.M. Yet in that relatively brief period of time he claimed to have inspected all facilities and spoken privately with all the 127 prisoners. 66

As for his compliance with the prison rules and regulations, Hawkins explained that he was only "somewhat familiar" with them as he had received a copy of them just a month before appearing before the committee. He stated that he kept no records of prisoner punishment and did not require the camp personnel to keep him informed of discipline problems. He assumed the sergeants were "high-toned gentlemen, [and] they know the rules better than I."67

He admitted that he did not inspect carefully the amount of provisions on hand in each camp as it would be futile since he did not know how much food had been requisitioned. He also said he had no way of knowing if the

$$
\begin{aligned}
& { }^{66} \text { Ibid., pp. 319-322. } \\
& { }^{67} \text { Ibid., pp. } 322-324,428-429 .
\end{aligned}
$$


bulk of the food was going to the prisoners or was being used to feed the guards' families. When asked if he ever made surprise visits to the camps to see what might be happening behind his back, Hawkins explained that he had "never done that. I am not a detective." Members of the committee reminded him that the state paid him very well to be a detective but Hawkins remained firm in his aversion to unannounced visits, "a fellow wouldn't last long at that--to slip around losing sleep all the time."68

J. G. Barbee, the inspector of the southern district, exercised supervision over seventeen camps on thirteen farms. As he saw it, his duty was "to visit the camps; see that the convicts are properly fed and clothed; that they are not overworked and that they are not abused in any way, and to see that they do the work that is required of them." Like Hawkins, Barbee left punishment of the prisoners to the discretion of the camp sergeants whom he described as "humane. . . " When the committee questioned the wisdom of relying so completely on the judgment of camp personnel in disciplinary matters, Barbee became very agitated and retorted angrily that he had done more for the unfortunate persons in Texas prisons "than all of you folks [the investigating committee] put together, everyone of you." He said he would not consider 
refusing a sergeant's request to discipline a prisoner because, "I believe every one of them, [sergeants] without a single exception, to be upright, honorable men, trying to discharge their duty."69

Barbee seemed to have been offended that the committee would presume to question his methods of doing his job. He lost his temper a second time when he was asked if he wrote his monthly reports from his own observation or simply repeated information given to him by sergeants. His response became so acerbic that the committee chairman had to remind him to observe the proper rules of decorum in his replies to questions. 70

The pointed interrogation of the inspectors reElected the realization that these two men, more than any other state officials, were responsible for carefully monitoring activities in the camp to see that the rules and regulations were followed. They served as the eyes and ears of those more senior prison officials who bore the overall responsibility for the system yet did not have the time to visit personally all of the remote places where prisoners were kept.

As events subsequently would prove, the committee's interest in the inspectors was well directed.

$$
\begin{aligned}
& 69 \text { Ibid., pp. 403-408. } \\
& { }^{70} \text { Ibid., p. } 411 .
\end{aligned}
$$


Several witnesses provided information to indicate that very little serious inspecting took place as a rule. One witness testified that he had complained once to one of the inspectors and had been whipped every day for four months afterward. Another mentioned that he had received eighty licks for reporting abusive treatment by the guards to inspector Barbee. R. J. Ritchie, a former sergeant, told the committee that it was not uncommon for the inspectors to mail signed but blank punishment slips to the camps. The sergeants could then punish a prisoner, write the prisoner's name on one of the slips, and mail it back to the inspector for his records. 71

Several witnesses described for the committee the manner in which the inspectors discharged their duties. One prisoner mentioned that inspector Hawkins only visited him camp every three or four months and that, in the absence of a personal visit, wrote the sergeant for a report on camp activities. On those occasions when Hawkins did come and talk with the prisoners, he would address them while they were assembled in a group and ask if anyone had any complaints to make. Guards were present frequently so prisoners would not speak freely and risk punishment later. The prisoner went on to explain that even had the guards not been present, most inmates would not have

${ }^{71}$ Ibid., pp. 396-400,730, 873 . 
spoken candidly in front of their fellow prisoners for fear that, in return for special treatment, one of their number would have informed the camp authorities. 72

The testimony of prisoners regarding the inefficacy of inspection received support from former inmates who, upon their return to free society, wrote of their imprisonment and touched on the quality of inspection. Charles Campbell described an inspection visit to a camp in which he was working. The inspector went among the men to inquire into their treatment, "and this was done in an insulting and braggadocio manner." when a man told the truth as to how the prisoners were treated, the inspector gave his name to the sergeant, who whipped him severely after the inspector had left the camp. ${ }^{73}$

$$
\text { Another former prisoner, J. L. Wilkinson, wrote }
$$

that a prisoner learned very early in his confinement to keep quiet about the conduct of sergeants and guards and their treatment of prison inmates. To do otherwise was to risk "being beaten unmercifully, if not to death." Wilkinson explained that, generally, the inspectors questioned the men in front of the camp personnel in the following fashion:

72 Ibid., pp. $389,571$.

73 Campbell, Hell Exploded, pp. 29-30. 
The inspector: Well, boys, how are you treated?

All right, Colonel.

How are you fed?

All right.

Is your grub well prepared?

Yes, sir, Colonel.

Does the sergeant whip you much?

No, sir, Colonel.

Do you get plenty of good clothes?

Yes, sir, Colonel.

Pleased with the responses to his inquiries, the inspector turned in a "flowery and satisfactory" report to his superiors, even though many of the men as they responded to the questions were "stinking with sores from wounds and beatings. . . ${ }^{74}$

By far the most strident criticism of inspectors came from former prisoner John Shotwell, who, following his release, described an inspection visit made to a "cotton plantation" where he was incarcerated near Cameron, Texas. He wrote that the prisoners would have preferred to see "the devil" rather than the inspector. According to Shotwell, the inspector would line up the men and "with a contemptible smile of mockery" ask how the "thieves [were] getting treated." He would order the guards to give the men plenty of work to do, and "if any of them begin to shirk, don't spare the leather, for I find in the convict business, that the using of the leather is just as

${ }^{74}$ Wilkinson, Trans-Cedar Lynching, pp. 86-87. 
essential as feeding." 75

When one of the prisoners made complaint about the working and living conditions on the farm, the inspector became upset and sneered at the man.

Now, look here, what to you think that you thieves deserve--the Menger hotel in San Antonio? You stuckup cuss, I'll teach you something. Here, captain, take this man out and give him 39 lashes and maybe next time I come here he will remember me.

According to Shotwell, the complaining prisoner "at once" received a "most terrible beating. . . ." The following day, the wounds of the whipping had not closed and "the blood soaked through his shirt and the flies blowed it." 76 The manner in which inmates in the Texas prison system were treated during the late nineteenth and early twentieth centuries cannot have been a source of pride for the state. The growing prison population, made up chiefly of young persons from the minority segments of the populace, found itself on contract prison farms where labor became the prisoners' only asset. Working long grueling hours, the inmates had to endure any form of discipline the camp authorities chose to impose, no matter how sadistic or perverted.

In addition to the demanding work routine,

75 John Shotwell, A Victim of Revenge or Fourteen Years in Hell (San Antonio, Texas: $\Xi$. J. Jackson Company, 1909, ?. 17 .

$76_{\text {Ibid. }}$ 
prisoners suffered shortages of food, clothing, medical care, and proper sleeping quarters, all of which could have helped ameliorate the otherwise hellish aspects of prison life. Legislative investigations of the prison during the period generally remained perfunctory at best and made no genuine effort to uncover and correct the sordid conditions that existed. Not until the end of the first decade of the twentieth century did an impartial and thorough examination bring to light the accumulated errors of the past and present to the citizens of the state an accurate picture of life in the Texas prison system. $\lambda$ The variety and abundance of evidence unearthed by the investigating committee in 1909 and 1910 formed a virtually unimpeachable indictment of prison maragement. Testimony of inmates and prison officials revealed egregious and unchecked violations of prison procedures going back several decades. The administrative mechanism for identifying and correcting problems, the regular inspection, was shown to have been faulty, unreliable, and negligent. That such conditions had been permitted to continue for so long a time can be blamed on those prison officials and other state leaders who viewed the purposes of the prison system as being other than the confinement and reformation of the offender. 
CHAPTER VI

\section{THE POWERS THAT WERE: THE LEADERSHIP \\ OF THE PRISON SYSTEM}

The deplorable conditions that prevailed in the Texas prisons during the lease and contract periods proved to be immune to any substantive attempts at remediation. Indeed, mistreatment of the prisoners and the ruthless exploitation of their labor constituted veritable hallmarks of the system at the time. Those parts of the rules and regulations that sought to guarantee to the inmates some consioeration of their basic human needs were ignored, for the most part. As long as the system showed a clear profit, all other concerns became secondary.

The preoccupation with profits and earnings made it easy to wink at all but the most egregious violations of the rules. The individuals who managed the prison system during the period must be assigned much of the culpability for the failure to govern the institution in strict accordance with the regulations. Yet not all of the prison personnel universally ignored the regulations and dealt with the prisoners in any way they saw fit. The available evidence indicts with some authority a good 
many prison officers; but, just as surely, it exonerates others.

This chapter will attempt to analyze the men who managed the state prison system during the late nineteenth and early twentieth centuries. It will examine their backgrounds, their qualifications for office, and the reasons they were selected to fill their respective positions. Personal information could not be obtained on all the major prison officials of the period. Enough was available, however, to draw a reasonably accurate profile of the type individual to whom the state entrusted the care of its convicted felons.

The prison officials to be examined will be restricted to those persons at the higher managerial levels who had a measure of broad responsibility for both formulating and imolementing prison policy. This group includes the prison directors, superintendents, assistant superintendents, and inspectors, all of whom were appointed by the governors. The individuals who served as physicians and chaplains in the system will be omitted from scrutiny as they generally were not full-time employees and, as a rule, had little or no influence on the formulation of policy. I

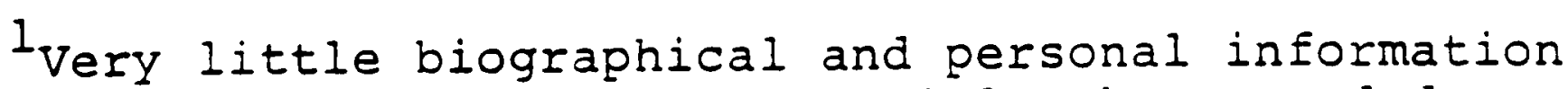
could be found for those prison officials who served during the $1870 \mathrm{~s}$ and early $1880 \mathrm{~s}$. The focus of this chapter, therefore, must concentrate on the individuals who served during the latter years of the nineteenth century and the Eirst decade of the twentieth century. 
An attempt will be made also to identify the people who hired the labor of the prisoners. This description of the contractors will emphasize who they were, their status in Texas society, and the influence they had on the leasing system itself. Once again, a dearth of information precludes a detailed look at all but a relatively small number of the more prominent individuals. Nevertheless, the observations and conclusions about the smaller group will have a reasonable degree of validity for all.

The highest administrative authority in prison matters during the lease and contract periods resided with the board of prison commissioners, at times referred to as directors. The governors appointed the members of the board so that each new administration brought new faces to deal with prison problems. Initially, the duties of the commissioners focused closely on the actual daily operations of the prison. Such careful monitoring of prison activities dictated that the board members live in or near the town of Huntsville. 2

The growing complexity of the prison system, coupled with the resumption of state control and the addition of the Rusk penitentiary in 1883, necessitated changes in the function of the prison board. It became less involved with the daily operations $O \equiv$ the prisons

2 paschal, Digest of the Laws of Texas, ?. 403 . 
and more concerned with advising the governor and managing the business affairs of the institutions. Board members had responsibility for making all contracts for repairs and improvements to the physical facilities; for establishing factories in the prisons; for purchasing additional land and equipment; and for promulgating all rules and regulations. ${ }^{3}$ As a consequence of the expanded role assigned to the prison board, the seat of power in penitentiary matters shifted after 1883 from Huntsville to the state capitol in Austin.

Generally speaking, the individuals selected to serve as prison commissioners had achieved a generous

3 Rules, Regulations, and By-Laws, 1893, p. 37; Rules, Regulations, and By-Laws for the Government and Discipline of the Texas state Penitentiaries and the Convicts Belonging Thereto at Huntsville and Rusk and at Outside Camps (Austin: State Printing Office, 1888), pp. 49-50. There is reason to suspect that despite the rather elaborate definition of their duties, prison commissioners exerted little direct influence in penitentiary matters. In his unpublished autobiography, A. P. Wooldridge, who served as a commissioner during the Hogg administration, wrote that the position was "purely honorary." Further evidence to support wooldridge's assertion appears in a letter to E. M. House from J.S. Rice, financial agent, dated December 23, 1898. Rice proposed the names of two people to serve as prison commissioners, urging their appointment as they would be cooperative and not get in the way. They would "at all times act strictly in line with the Governor's wishes. . . " A. P. Wooldridge Collection, Box 2L124, Barker Texas History Center, University of Texas at Austin, Austin, Texas; J. S. Rice to E. M. House, December 23, 1898, E. M. House Papers, 1896-1911, Box 2R42, Barker Texas History Center, University of Texas at Austin, Austin, Texas. 
measure of success in their chosen fields. Commerce and the law appear to have been the most common professions. In addition, most had held an elected office at either the state or county level and thus understood the machinations of state Democratic politics and political leaders. To obtain a more accurate picture of a typical prison commissioner, it will be useful to examine the lives of a few of the men as representative examples of the entire group. One of the commissioners who served during the early years of lease, H. K. White, was an Alabama native who came to Texas in 1841 at the age of thirteen. White grew up in Grimes County where he served as county treasurer in the years 1858 to 1862 . Because of a physical disability, White was exempt from military service during the Civil war. After farming in Grimes County until 1873 he moved to Ellis County. He began his service with the penitentiary when Richard Coke appointed him assistant inspector in late November, 1875. Coke's successor, Richard Hubbard, appointed White to the prison board, a position he held until the election of $O$. M. Roberts in $1878 .^{4}$

Although White departed prison service upon the

${ }^{4}$ Scrapbook, Richard Coke Papers, Box 3L130, Barker Texas History Center, University of Texas at Austin, Austin, Texas; John Henry Brown, Indian Wars and Dioneers of Texas (Austin: L. E. Daniell, Publisher, n.d.), pp. 420-421. 
inauguration of the Roberts administration, his association with the institution, and with state politics, continued for many years thereafter. One of his biographers described him as a lifelong Democrat and a frequent delegate to state Democratic conventions. During the latter decades of the nineteenth century, he represented Burleson and Brazos counties in the Eighteenth and Twenty-third Legislatures, respectively, and amassed sizable land holdings in those areas. Beginning in 1880 and continuing through 1900, he leased state prisoners to work his farms. 5

J. T. Mewshaw, appointed to the prison board during the first term of Thomas Campbell, was, like H. K. White, a "prominent Democrat" known "throughout" the state. He had come to Texas in 1877 from Missouri and had settled in Garland, where he became active in civic affairs and politics. Although he was a man of "little book learning," he managed to establish a large and prosperous blacksmithing business. Apparently, the governor appointed him as a reward for the many years

5 Brown, Indian wars and Pioneers, pp. 420-421; Members of the Legislature, 1846-1939, pp. 115, 156; Biennial Report, 1880 , p. 51; Biennial Report, 1882, p. 8; Biennial Report, 1884, p. 29; Biennial Report, 1886, p. 36; Biennial Report, 1888, p. 19; Biennial Report, 1890, p. 56; Biennial Report, 1892 , p. 4; Biennial Report, 1894, p. 6 ; Biennial Report, 1896 , p. 6; Biennial Report, 1898, p. 8; Biennial Report, 1900, p. 8 . 
he had worked in behalf of Democratic candidates of the state. 6

Another civic leader, A. P. Wooldridge of Austin, earned his spot on the prison board through service to his community and the Democratic Party. Wooldridge had been born in New Orleans in 1847. After attending Yale University and the University of Virginia, he finally settled in the Texas capitol in 1872 and opened a law practice. Hr organized the first public school system in the city, served on the committee established to choose a site for the University of Texas, and served as the first secretary of the institution's board of regents. He was president of the City National Bank in Austin and mayor of the city from 1909 through 1919. Governor Hogg appointed Wooldridge, who remained on the board during both of Hogg's terms. 7

The two men who served longest as commissioners of the prison followed similar careers in other ways. Both Walter Tips and William Clemens were born in Germany.

${ }^{6}$ L. B. Hill, editor, A History of Greater Dallas and Vicinity 2 (Chicago: The Lewis Publishing Company, 1909): 109-110; Biennial Report, 1908, p. 4.

${ }^{7}$ Walter Prescott Webb, editor-in-chief, Handbook of Texas 2 (Austin: The Texas State Historical Association), 1952): 933-934; Biographical Encyclopedia of Texas (New York: Southern Publishing Company, 1880), p. 239; Biennial Report, 1892, p. 18; Biennial Report, 1894, p. 2 . 
They came with their families and settled near New Braunfels, Texas in 1849. Both were veterans of the Confederate Army, had served in the state legislature and, for many years, were business associates. Nor surprisingly, the two men also became lifelong friends. 8

Walter Tips served under four governors, Ireland, Ross, Lanham and Campbell, for a total of twelve years. In between his years of service on the prison board, he represented Travis County in the Seante of the Twentythird and Twenty-fourth Legislatures and was appointed by Governor O. B. Colquitt to serve on the State Library and Historical Commission. He established the Walter Tips Company, a hardware firm considered by contemporaries to have been "one of the leading commercial enterprises of Austin. . . . "9

William Clemens served a total of eight years on the prison board, under Governors Culberson and Sayers. He began his political career as an alderman in the city of New Braunfels and went on to represent Comal County

${ }^{8}$ L. E. Daniell, Personnel of the Texas State Government, with Sketches of Representative Men of Texas (San Antonio: Maverick Printing House, 1892), pp. 193194; Austin Statesman, January 21, 1912, p. 1.

${ }^{9}$ Austin Statesman, January 21,1912, p. 1; Members of the Legislature, 1846-1939, pp. 151-160' Biennial Report, 1884, p. 3; Biennial Report, 1886, p. 5; Biennial Report, 1888, p. 3; Biennial Report, 1890, p. 3; Biennial Report, 1906 , p. 4; Biennial Report, 1910, p. 8. 
in the House of Representatives of the Sixteenth and Twenty-first Legislatures. In 1890, he represented the same area in the state Senate. While in the upper house, Clemens supported bills favoring public school improvement and the creation of a state railroad commission, but opposed the use of free railroad passes by members of state government. ${ }^{10}$ Both Clemens and Tips, of course, were members of the Democratic Party.

Since the duties of the prison board were linked so closely to the purely financial aspects of prison management, the commissioners needed no experience actually working with the penitentiary system prior to their appointment by the governors. The kind of expertise they could bring to prison management could be obtained just as easily, if not better, in the competitive commercial atmosphere outside state service. Such was not the case, however, with the individuals chosen to manage the prisons and supervise prison personnel. The qualifications needed to fulfill the duties of superintendent, assistant superintendent, and inspector necessitated some familiarity with the manner in which prisons operated and, of equal importance, the ways inmates should be handled.

10 Daniell, Personnel of the Texas State Government, po. 193-194; Members of the Legislature, 1846-1939, pp. 96, 135, 140; Brown, Indian Wars and Pioneers, po. 330-331. 
Unfortunately, in a good many cases, the persons chosen to staff the prisons received their appointments because of faithful political service to the incumbent governor rather than for any professional experience they might have possessed. Some of the appointees, nonetheless, acquitted themselves well in their prison jobs; others, however, performed miserably and it is to this latter group that one may attribute much of the blame for the chronic problems of the prison system. When speaking of the major prison officials of the period 1870 through 1912, the name of Thomas J. Goree stands clearly above all others. His preeminence derives, in part at least, from the sheer length of his service to the state. More importantly, however, Goree displayed a commitment to his tasks and a sensitivity to the purposes and objectives of confinement unparalleled in any of his associates and contemporaries.

Goree began his official association with the prison in 1874 when Governor Coke appointed him to serve as one of the directors in Huntsville. At the time of his selection, he was struggling none too successfully to build a law practice. Born in Alabama in 1835, he came to Texas while still a young man and graduated from Baylor University in 1856. During the Civil war he served first as a scout under P. G. T. Beauregard and from July, 1861 on as an aide-de-camp to General James Longstreet. No 
doubt his close association with the law firm that represented the interests of Ward, Dewey and Company played a part in securing for him the appointment to the prison board. 11

Following his appointment to the superintendency by Governor Hubbard in the spring of 1877, Goree went on to manage the system through the last years of lease and the early period of state control. During his tenure in office he established contact with and became a member of the National Prison Association and sought to incorporate into the Texas system the newer theories of prison management espoused by the national organization. It seems highly probable that Goree's consistent support for such reforms as the indeterminate sentence and a separate institution for juvenile offenders grew out of his early contacts with those persons seeking reforms in America's prisons during the late nineteenth century. ${ }^{12}$

11 Reports of the Texas State Penitentiary, 1873-4 p. 2; Biograohical Souvenir of the state of Texas, Containing Biographical Sketches of the Representative Public and Many Early Settled Families (Chicago: F. A. Battey \& Company, 1889), p. 333; Galveston Daily News, June 18, 1876, p. 4; Henri Gerard Nordberg, "A Young Texan Goes to War, A Collection of Personal Letters by Captain Thomas Jewett Goree, C.S.A., Aide-de-Camp to General James Longstreet," Journal, Confederate historical Society, vol. 7, No. 4 (winter 1969): 142-159; Proceedings of the Annual Congress of the National Prison Association of the United States, held at Austin, Texas, December 2-6, 1897 (Pittsburgh, Pa.: Shaw Brothers, Printers, 1898), p. 131 .

\section{Proceedings of the Annual Congress of the} Vational prison Association of the United States, held 
In the spring of 1891, the newly-elected governor, James S. Hogg, refused to reappoint Goree. During the gubernatorial election of 1890, Goree and one of his uncles, Norman Kittrell, a well-known attorney, were unenthusiastic in their support of Hogg. For this bid of perceived disloyalty, the new governor was unforgiving. Goree became a casualty of a system in which one's competence and achievements were secondary to one's political activities. ${ }^{13}$

at Boston, July 14-19, 1888 (Chicago: Knight and Leonard Company, Printers, 1888), pp. 308-320; Proceedings of the Annual Congress of the National Prison Association of the United States, held at Cincinnati, September 25-30, 1890 (Pittsburgh: Shaw Brothers, Printers, 1891), p. 317 .

13 Norman Kittrell to James S. Hogg, December 10, 1890, Governor's Letters Received, James S. Hogg Papers, Barker Texas History Center, University of Texas at Austin, Austin, Texas.

A measure of Goree's stature in the National Prison Association and the high regard in which he was held by the membership appeared in a letter to Governor-elect Hogg from Frederick H. Wines, executive secretary of the organization. Wines urged Hogg to retain Goree as he was recognized as one of the more distinguished prison officials in the country. He was a man of "strength, good sense, integrity, and good feeling." The Texas prison, under Goree's management, had built an enviable record that would surely be destroyed if he failed of reappointment.

"I voice the sentiments of every leading member of the National Prison Association when I say that the removal of $\mathrm{Mr}$. Goree for any but causes affecting his personal or official character or conduct would be regarded by them generally as a misfortune to the cause of prison reform in the United States against which they would protest if they had the opportunity to do so and were sure that their protest would be received in the spirit in which it is offered." Frederick H. Wines to James S. Hogg, April 6, 1891, Governor's Letters Received, Vol. 12, James S. Hogg Papers. 
Goree's successor, Lucius A. Whatley, served under both Governor Hogg and his successor, Charles A. Culberson, for a total of eight years. Whatley was a native of cass County, Texas and had represented the area in the House of Representatives of the Twentieth and Twenty-first Legislatures. He won election to the state senate in 1890 but resigned to accept the appointment as superintendent of the prison. 14

Whatley's governance of the prison, in a word, was undistinguished. Like all of the men who served as superintendent after 1890, his comments on prison policies and programs were little more than restatements of remarks made previously by Goree. He did maintain the contacts that had been established with the National Prison Association but did not enjoy the prestige within the organization that had been accorded his predecessor. 15

\section{L. E. Daniell, Personnel of the Texas State} Government with Sketches of Distinguished Texans, Embracing the Executive and Staff, Heads of the Departments, United States Senators, Representatives, Members of the Twenty-first Legislature (Austin: Smith, Hicks, and Jones, State Printers, 1889), p. 349; Members of the Legislature, 1846-1939, pp. 131, 138, 142 .

\section{5 proceedings of the Annual Congress of the}

National Prison Association of the United States held at Denver, Colorado, September 14-18, 1895 (Pittsburgh: Shaw Brothers, Printers, 1896), p. 357; Proceedings of the Annual Congress of the National Prison Association of the United States, held at Milwaukee, Wisconsin, September 26-30, 1896 (Pittsburgh: Shaw Brothers, Printers, 1897), p. 388; Annual Congress National Prison Association, 1897, . Iv; Biennial Report, 1892, pp. 3-17; Biennial Report, 1894, pp. 5-20. 
Like Goree, Whatley condemned the practice of hiring state prisoners to outside parties. It was, he argued, a necessity that could be overcome only with the purchase of farm land by the state to work the prisoners on state account. One has reason, however, to question the degree to which his opposition was genuine. For approximately ten years after his service as superintendent ended, Whatley engaged groups of prisoners to work his farm in Madison County, Texas. From testimony taken during the legislative investigation of 1909-1910, conditions on Whatley's farm appeared no better than those which prevailed in the other camps. 16

As the second term of Governor Culberson came to an end with the elections in late fall, 1898, so did Whatley's tenure as head of the prison. Beset with severe financial problems, he pleaded almost desperately with the new administration, seeking to retain his position as superintendent. Unfortunately for him, the incoming

16 Biennial Report, 1900 , p. 29 ; Biennial Report, 1902 , p. 38; Biennial Report, 1904, p. 38; Biennial Report, 1906, D. 28; Biennial Report, 1908, p. 32; Biennial Report, 1910 , p. 35; Legislative Investigation, 1910, Pp. 477-501. What ley came in for criticism also from one of the governors who appointed him. At one point, Governor Culberson described him as one of the "champion nepotists of the age without a doubt." Apparently, Whatley had placed so many of his friends and relatives on the prison payroll that he had managed to transgress what must be described as the unusually liberal standards of the day. Charles A. Culberson to E. M. House, undated, Roll \#114, House Papers, Barker Texas History Center, Austin, Texas. 
governor, Joseph Sayers, refused the request. Whatley had made the mistake of supporting one of sayers' opponents during the primary campaign and, although he later worked for Sayers, his early disloyalty apparently cost him his job. 17

The three men who served as superintendent after Whatley all had the advantage of some experience in prison administration before their appointment to the top job. All three expressed opposition to working state prisoners on private farms, much as their predecessors had done, yet none took any significant steps to accomplish its end. They simply accepted the system as it existed and preferred not to tamper with it except, perhaps, to increase its profitability.

J. S. Rice, who immediately succeeded whatley, had entered penitentiary service originally in 1894, when Governor Culberson had appointed him financial agent. He was a graduate of the Texas Military Institute and had become very successful in banking and in the sawmiling business. Upon the election of Governor Sayers in 1898, Rice was elevated to the position of superintendent and held the job until April 11, 1902 when he resigned to

17 L. A. Whatley to E. M. House, Apgust 8, 1898, Box 2R42, House Papers; R. R. Lockett to E. M. House, November 13, 1898, Roll 112, ibid. 
become president of the Union National Bank in Houston. 18 Rice's successor, Searcy Baker, was an $1882 \mathrm{grad}-$ uate of the Texas Agricultural and Mechanical College. Baker became successful in farming and in lumbering and in 1899 secured a position in the prison financial agent's office. He served as superintendent through the administration of Governor S. W. T. Lanham, but was replaced after Thomas M. Campbell was inaugurated in 1907. After leaving penitentiary service, Baker became the superintendent of police in the city of Houston. 19

The last superintendent during the state contract period, J. A. Herring, served with the Campbell administration, 1907-1911. Herring had gone to work for the prison system initially in 1892 as manager of the Harlem state farm, a position he held until 1899 when he returned to his home in Madison County and managed his agricultural interests. Shortly after his return home, he was elected president of the First National Bank in Madisonville. 20

18 H. T. Warner, Hugh N. Fitzgerlad, T. C. Gooch, T. S. Bonner, J. L. Mapes, and Edmunds Travis, eds., Texans and Their State (Houston: The Texas Biographical Association, n.d.), p. 269; Biennial Report, 1896, p. I; Biennial Report, 1900, p. 17; Biennial Report, 1902, p. 15.

19 Warner et al., Texans and Their State, p. 292; Biennial Report, $1902, \mathrm{p} .14$; Biennial Report, $1904, \mathrm{p}$. 10; Biennial Report, 1906, p. 4 .

20 Dermot H. Hardy and Ingham S. Roberts, eds., Historical Review of South-East Texas, 2 (Chicago: The Lewis Publishing Company, 1910): 841-842. 
During the time that Herring lived in Madison County between his periods of service in the prison system, he, along with former superintendent whatley, leased state prisoners to work his farms. The joint venture, known as the Whatley and Herring farm, lasted until Herring was named superintendent. Herring apparently remained active in politics throughout his tenure with the prison system. Because of his early support for the nomination of woodrow Wilson in 1912, he received the appointment as United States Marshall for the southern district of Texas shortly after Wilson was inaugurated as President. 21

The same factors, material success and political activity, that figured so prominently in determining the individuals chosen to sit on the penitentiary board or serve as superintendent, also came into play, to some degree, in selecting the middle level administrators.) Men of some prestige in the state also became the assistant superintendents and inspectors although, as a rule, they were neither as prominent nor as financially independent as the superior officers. In most cases, people accepted the middle level positions solely for the salaries they provided rather than from a sense of civic

\section{E. Daniell, Texas, The Country and Its Men} (n.p.: n.d.), pp. 763-765; Biennial Report, 1900, p. 29 ; Biennial Report, 1902, p. 38; Biennial Report, $1904, \mathrm{p}$. 38; Biennial Report, 1906 , p. 28; Biennial Report, 1908 , p. el; Legislative Investigation, 1910, D. 257 . 
duty. In addition, much more in the way of continuing political service was required of those appointed to fill the positions. An examination of several of the individuals who served as assistant superintendents and inspectors will illustrate the similarities and differences they shared with the higher level prison administrators.

R. H. Underwood, a native of Alabama, came to

Texas in 1883 and established a farm in Bell County. In 1893, President Grover Cleveland appointed him postmaster in Holland, Texas. Six years later, prison superintendent J. S. Rice selected Underwood to manage the Dunovant prison farm near Eagle Lake, Texas, where he remained until 1905, at which time he returned to Holland and took a position as cashier at the First National Bank. Underwood reentered state service in 1907 when Governor Campbell appointed him assistant superintendent at Huntsville. During his time at Huntsville, Underwood attended national meetings of the American Prison Association and was elected a vicepresident of the American Prison Warden's Association. He remained as assistant superintendent until January, 1911 when a new governor, O. B. Colquitt, replaced him. 22 E. G. Douglas, who served as assistant

22 Hardy and Roberts, Historical Review of SouthEast Texas, 2: 311-815; Annual Report of the Officials of the Texas prison System for the Year Ending December 31,1911 (Austin: Von Boeckmann-Jones Co., Printers,

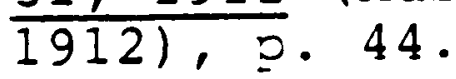


superintendent at Rusk under Governor Ross, began his political career as sheriff of Grayson County. He was elected state senator from the county in 1886 and served until January, 1889, when Ross named him to the Rusk position. In 1896, superintendent whatley placed him in charge of the Burleson and Johns share farm where he remained until 1899, when he was made manager of the Harlem state farm. Early in 1907 he became assistant superintendent of the juvenile reformatory in Gatesville, where he died in December, 1907.23

James P. Gibson replaced Douglas as assistant superintendent at Rusk. Appointed initially by Governor Hogg, Gibson served also for both terms of Hogg's successor, Charles A. Culberson. He had first entered politics as county surveyor in Cherokee County, where subsequently he served for thirteen years as county judge. Gibson remained at the Rusk prison until the inauguration of Culberson's successor, Joseph Sayers. 24

23 Searcy Baker to the editor, Dallas Times Herald, January 14, 1907, Box 2-11/364, Thomas M. Campbell Papers, Texas State Library and Archives, Austin, Texas; Biennial Report, 1894, p. 59; Biennial Report, 1900, p. 11; Biennial Report, 1902 , p. 20; Biennial Report, 1904, p. 18; Biennial Report, 1906, p. 13; Biennial Report, 1908, p. 86.

24 Sid s. Johnson, Texans who Wore the Gray, vol. I (n.p.: n.d.): 199-200; Frank W. Johnson, A History of Texas and Texans, vol. 3 (Chicago: The American Historical Society, 1914): 1277-1278; James P. Gibson to E. M. House, December 11, 1898, Box 2R42, House Papers. 
A sampling of the men who served as inspectors indicates that they too brought a variety of experiences to their tasks. As a rule, inspectors tended to be people with considerable local or regional prominence who, through their knowledge of local conditions, could function as political operatives for the administration in Austin. Inspectors frequently were called upon to serve as a vehicle for transmitting the wishes and desires of the governor to the party faithful at the county level and below. The amount of politicking engaged in by the inspectors suggests that an aptitude for such activities figured prominently in the selection criteria.

One of the earliest inspectors, Daniel M. Short of Shelby County, did not conform so typically to the later image of inspector as a purely local politico. Short was appointed prison inspector by Governor O. M. Roberts in 1878 and retained the position until 1886 . His job with the prison system was the culmination of a long and active career in state politics.

In 1846 , Short and Roberts opened a law practice in Shelbyville, Texas, beginning an association that would endure all their adult lives. Short served in the war with Mexico and organized a military company from his county in the Civil war. He served as a member of the Eighth and Eleventh Legislatures of Texas, as a delegate to the Secession Convention, and from 1866 to 1892, as 
chairman of the Democratic executive committee of his district and county. Roberts' appointment of Short, in addition to its inherent political wisdom, probably reflected the governor's concern that he be kept au courant in prison matters. Roberts wanted the prison system to function according to the rules and regulations so as to eliminate the causes of public dissatisfaction with the manner in which prisoners were treated. By naming a trusted friend to serve as inspector, the governor, no doubt, assumed he would receive more reliable reports on conditions, particularly in the outside camps. ${ }^{25}$ None of the other individuals who served as inspectors would enjoy the close personal relationship with the chief executive that existed between Roberts and Short.

J. G. Barbee of Wharton appears more typical of the majority of inspectors. Barbee, a merchant and farmer, had been instrumental in reestablishing Democratic Party control of wharton County in 1886. He won election to the House of Representatives of the Twenty-third Legislature in 1892 and was elected to serve as county judge in 1896. He remained a powerful force in local politics and in 1907 was appointed prison inspector by Governor Campbel1. 26

$$
\begin{aligned}
& 25 \text { Johnson, Texas and Texans } \\
& { }^{26} \text { Ibid., pp. 1295-1296. } 2010 .
\end{aligned}
$$


Another inspector, Wharton Bates, a Brazoria attorney, also developed his political skills in a predominantly local setting. Bates, as a member of the Jay Bird Democratic Association of Fort Bend County, participated in that organization's takeover of county politics in the late 1880s. Bates' work in behalf of the Democratic Party came to the attention of state Democratic leaders in Austin and, following Culberson's election in 1894, the governor offered him the position of prison inspector. 27 It is difficult to overstate the importance of the prison system to the political structure of the state during the late nineteenth and early twentieth centuries. In choosing persons to staff the prison, governors seemingly placed a premium on previous political service and the potential for continuing effort in behalf of the Democratic Party and the incumbent elected officials. Securing a position within the prison came to be viewed as a reward for faithful political service; but it was a gift that could be withdrawn abruptly if one failed to continue working to further the interests of those who had bestowed the appointment.

27 Wharton Bates to E. M. House, September 1, 1894, House Papers, Roll \#109; The Jay Bird Democratic Association of Fort Bend County was a white man's political organization established in 1889 to seize control of the county political machinery from the majority black population. Pauline Yelderman, The Jay Bird Democratic Association of Fort Bend County, A White Man's Union (Waco, Texas: Texian Press, 1979), po. 119-144. 
The manner in which prison officials were expected to perform in the service of the political administration became established very early in this period. In late summer, 1880, Superintendent Goree, acting in concert with former Governor Richard Coke, intervened to defuse a potential political challenge against the incumbent Governor, O. H. Roberts, who was under fire from some Democrats because of his fiscal retrenchment policies. The challenge to the governor came from former Confederate General Jerome B. Robertson of Waco. 28

Shortly after Robertson took the first tentative steps toward announcing his candidacy, Coke sent "seven or eight of our best men" to talk to the general and attempt to dissuade him. Coke also ordered Goree to meet with Robertson and stress the futility of opposing the reelection of Roberts. After talking with Robertson, Goree noted that the general was intent on running, even though he knew he had little chance of winning. As it turned out, however, Robertson was unable to attract the financial backing necessary to conduct a statewide campaign, so his opposition to Roberts amounted ultimately

28 T. J. Goree to Governor O. M. Roberts, August 23, 1880, Roberts Papers, Barker Texas History Center, University of Texas at Austin. Opposition to Roberts centered around his sale of the public lands at very low prices and his reduction in the state budget, especially for education items, to help reduce the level of state indebtedness. Barr, Reconstruction to Reform, pp. 58-59. 
to very little. 29

By the 1890s, the Austin to Huntsville to Rusk political axis, with branches down to the state farms, had become sophisticated enough to oversee electioneering activities at the county and precinct levels if necessary. The man chiefly responsible for monitoring and directing the political efforts of prison employees during that time was Edward M. House, adviser and confidant to Governors Hogg, Culberson, Sayers, and Lanham. These men served consecutively as the state's chief executives from 1891 through early 1907. Beginning with Hogg's campaign for reelection in 1892, House played an active role in distributing the patronage that fell within the purview of the governors. 30

${ }^{29}$ Goree to Roberts, August 23, 1880, and Richard Coke to Goree, September 3, 1880, Roberts Papers, Barker Texas History Center, University of Texas at Austin.

${ }^{30}$ By the last decade of the nineteenth century, the House family had become wealthy and influential in Texas society. T. W. House, $\mathrm{Sr}$., who came to Texas from England in 1837, established a general mercantile store in Houston and invested the profits of his business in land. At the time of his death in 1880, he owned in excess of 250,000 acres scattered over sixty-three Texas counties. Cotton and sugar cane were the major crops grown on the House properties.

upon the death of his father, Edward House managed to parlay his share of the family inheritance into a sizable operation of his own. He counted among his possessions several large farms around the state as well as profitable investments in streetcar, railroad, and oil companies. No doubt, the income from his business interests provided the wherewithal for him to devote so much o: his time to state politics. Rupert N. Richardson, 
In his capacity as trusted advisor to the chief executives--especially Culberson, Sayers, and Lanham-House kept close tabs, through prison personnel among others, on political happenings around the state. In addition, he used the contacts in the penitentiary service to work on behalf of specific candidates he wished to see win elective office. A good example of the manner in which House used prison employees at election time can be seen in the campaign he directed in 1898 to put Joseph Sayers in the Governor's office.

As the election season got underway early in 1898, the major candidates for the nomination of the Democratic Party included R. M. Wynne, an attorney from Fort Worth, M. M. Crane, attorney-general under the out-going Governor Culberson, Geerge T. Jester, Culberson's lieutenantgovernor, and Sayers, who at the time, was representing Texas in Congress. House had helped Sayers win reelection in 1896 and the congressman kept in close touch with his Texas benefactor throughout his next term in Washington. The friendship between the two men probably explains, at least in part, House's decision to back Sayers for

Colonel Edward M. House: The Texas Years, 1858-1912 (Abilene, Texas: Abilene Printing and Stationery Company, 1964), pp. 23-209; Johnson, Texas and Texans, 4 : 1645-1646; Barr, Reconstruction to Reform, pp. 209-210; Charles A. Culberson to House, August 23, 1907, House Papers, Roll \#110. 
governor over the other contenders. 31

House initiated the Sayers campaign by calling on members of the Culberson organization, many of whom owed him their positions, and instructing them to work for Sayers. Among those contacted were several people in the prison system. Wharton Bates, inspector for the southern part of the state, campaigned for sayers as he made his way around visiting the prison camps in the counties south and west of Houston. He reported his findings, with recommendations, back to House. Following a trip to Galveston in late February, for example, Bates noted with some concern that the Crane people had been working long and hard in the island city and had managed to line up the Galveston machine behind the attorney-general. Bates reported that he was doing everything he could for Sayers and asked House to suggest anything extra he might do for the ticket. The financial agent, J. S. Rice, working out of Huntsville, kept the Sayers forces in line in the southeast Texas area. In addition, he and "the boys" helped the campaign along with financial contributions. 32

In the process of waging a political campaign,

31 Barr, Reconstruction to Reform, pp. 211-212; Richardson, Colonel House, pp. 130-132.

${ }^{32}$ Richardson, Colonel House, pp. 137-138; Wharton Bates to House, February 28, 1898, J. S. Rice to House, March 21, 1898 and May 20, 1898, House Papers. 
House seemingly looked to every detail. In addition to keeping himself abreast of any shifts in the public mood, he and his co-workers corresponded widely with friends and potential supporters around the state and sent speakers into those areas where their candidate needed helo. Friends and acquaintances also were called upon for financial assistance. In the sayers campaign, money was solicited from some of the individuals who hired the labor of the state prisoners. Presumably, since these people benefited financially from the use of prison inmates, it seemed only fitting that they should repay the favor and come forth at election time with money. 33

All of the effort expended by the House people in behalf of Sayers enabled the congressman to win the June primary. House's personal leadership and the direction he lent to the campaing were crucial. Following the victory, Sayers, who had remained in Washington through the entire period, expressed his gratitude by pledging that he would consider no appointments in his administration without House's approval. 34

The financial role played in the sayers campaign by the contractors of prison labor is indicative of the

$33 \mathrm{~J}$. S. Rice to House, March 21, 1898, C. G. Ellis to House, February 4, 1898, House Papers.

${ }^{34}$ Richardson, Colonel House, pp. 154-155. 
position of this group in Texas society. For the most part, the persons who hired the labor of state prisoners were wealthy individuals with large landholdings. They used their financial resources to curry favor with, and perpetuate the control of, political factions and individuals who would not disturb the status quo in the prisons. To the degree that the contractors used their influence to protect and maintain their access to low-cost prison labor, they constituted a powerful ring interested only in its own self-preservation.

Throughout the period Texas prison inmates were worked on the state account system, a handful of leading citizens in the state predominated in the hiring of the prisoners. Beginning with the five-year contracts made in the fall of 1882, just before resumption of state control, one finds among the successful bidders a group of people that retained contracts for prison labor as long as they wanted them. Some of the contractors managed to keep their prison forces until all inmates were placed under state control in 1912. The more prominent employers of prison labor through the late nineteenth and early twentieth centuries included E. H. Cunningham, L. A. Ellis, R. S. Willis, P. J. Willis, T. W. House, the Ball, Hutchings Company, Albert Sydney Burleson, W. T. Eldridge, 
and T. S. Henderson. 35

E. H. Cunningham and L. A. Ellis were the principals in the firm of Cunningham and Ellis that had leased the entire prison in 1878. For many years following the revocation of their lease in 1883 , both men continued to use prison inmates to work their large landholdings in and around Fort Bend County. Cunningham, who lived most of his life in San Antonio, is considered to have been the principal founder and organizer of the extensive sugar industry in Texas in the area southwest of Houston. He used hundreds of state prisoners to work the cane plantations that provided the raw material for his refinery at Sugarland. As one of the larger contractors of prison labor, Cunningham exerted considerable influence in penitentiary affairs. He was related by marriage to the Brahan family, out of which came the first financial agent appointed following state resumption of control of the prisons. He also contributed to statewide political campaigns and was instrumental at one point in securing the superintendent's job for another businessman, Houstonian J. S. Rice. In 1907,

${ }^{35}$ The competitive bidding process by which prison forces were hired apparently was abandoned after 1887 in favor of a system wherein the state set the price it wanted for the prisoners. Those contractors already having a prison force were given first choice in keeping it if they agreed to meet the state's price. Biennial Report, 1888, ○. 19; "Minutes of the penitentiary board, July 10, 1907," Thomas M. Campbell Papers, Box 2-11/365. 
Cunningham sold his sugar refinery to a group of Galveston investors who did business as the Imperial sugar Company. He died in San Antonio on August 27, 1912.36

I. A. Ellis, like Cunningham, continued to utilize prison labor on his south Texas plantations, but moved to Austin following revocation of the lease and sold his interests at Sugarland to Cunningham. He still maintained an involvement with the state sugar industry, however, as evidenced by his election as vice president of the Texas Sugar Grower's Association in 1890. After moving to Austin, Ellis and George W. Littlefield, a wealthy cattleman, established the American National Bank in that city. A few years before his death in December, 1896, Ellis turned over the management of his business interests to his sons, who continued to use state prisoners to work the farms in

36 "Sugarland and the Men who Made It," pp. 1-2, unpublished manuscript in the Fort Bend County Historical Museum, Rosenberg, Texas; A. J. Sowell, History of Fort Bend County (Houston: W. H. Coyle and Company, Stationers and Printers, 1904), pp. 348-350; Clarence R. Wharton, History of Fort Bend County (San Antonio: The Naylor Company, 1939), P. 194; T. J. Goree to E. M. House, November 10, 1898, J. S. Rice to House, March 21, 1898, Box 2R42, House Papers; San Antonio Express, Augsut 28, 1921 ; Biennial Report, 1882, pp. 36-37; Biennial Report, 1884, p. 29; Biennial Report, 1886, p. 36; Biennial Report, 1888, p. 28 Exhibits; Biennial Report, 1890, p. 56; Biennial Report, 1892, p. 29; Biennial Report, 1894, p. 32; Biennial Report, 1896, p. 31; Biennial Report, 1898, p. 29; $\overline{\text { Biennial }}$ Report, 1900, o. 29; Biennial Report, 1902, 0. 38; Biennial Report, 1904, p. 36; Biennial Report, 1906, p. 27-28; Biennial Report, 1908, $\cong .31$. 
Fort Bend County. 37

Other major contractors of prison labor who also associated closely with the early sugar industry in Texas included T. W. House, R. S. Willis, P. J. Willis, and W. T. Eldridge. All were men of wealth and influence in the state. The importance of the prisoners to these sugar cane growers is illustrated best by noting the precipitate decline of the sugar industry in the state following the end of the contract system in 1912.38

T. W. House had perhaps the most influence on politics in Austin thanks to the position of his brother,

37 "Sugarland and the Men Who Made It," pp. 1-2; Austin Statesman, December 11, 1896, p. 12; Biennial Report, 1882, p. 36037; Biennial Report, 1884, p. 29; Biennial Report, 1886, p. 36; Biennial Report, 1888, p. 28 Exhibits; Biennial Report, 1890 , p. 36; Biennial Report, 1892, p. 29; Biennial Report, 1894 , p. 32; Biennial Report, 1896, p. 31; Biennial Report, 1898 , p. 29; Biennial Report, 1900, p. 32; Biennial Report, 1902 , p. 38; Biennial Report, 1904, p. 38; Biennial Report, 1906, p. 22-28. In 1890, L. A. Ellis' son, C. G. Ellis, made a spirited attempt to secure the lease of Louisiana's prison. Even though Ellis offered a substantial annual sum for the lease, his friends in the Louisiana legislature could not carry the vote for him. Mark T. Carleton, Politics and Punishment. The History of the Louisiana State Penal System (Baton Rouge: Louisiana State University Press, 1971), pp. 60-63.

${ }^{38}$ Several other factors also contributed to the demise of the raw sugar industry in the state, among them were: competition from duty-free raw sugar from abroad; disease; and unpredictable weather. William R. Johnson, A short History of the Sugar Industry in Texas (Texas Gulf Coast Historical Association, 1961), pp. 58-60. 
Edward. T. W. Owned and operated several large farms in the cane growing areas of the state and at one time was a major refiner of sugar. Two of his larger holdings were the Darrington farm in Brazoria County and the Arcola plantation in Fort Bend County. 39

The Willis brothers, P. J. and R. S., were natives of Maryland who came to Texas in 1836. They opened a small mercantile store in Montgomery, Texas which by the late $1850 \mathrm{~s}$ had grown to be "one of the largest houses in the state." After the Civil War, they moved the business to Houston and Galveston where it operated under the name of P. J. Willis and Brother. P. J. died in 1873, so his brother assumed full control. R. S. Willis later served as president of the Galveston National Bank, the Texas Guarantee and Trust Company, and was one of the founders of the Gulf, Colorado, and Santa Fe Railroad. He also was elected a vice president of the Texas Sugar Grower's Association. The Willis plantations were located in Brazoria County. 40

W. T. Eldridge, who owned extensive farms near

${ }^{39}$ Ibid., D. 57; Richardson, Colonel House, pp. 23-24. The Darrington property ultimately became part of the holdings of P. J. Willis and Brother, Biennial Report, 1896, p. 31 .

40 Johnson, Short History of the Sugar Industry, 2. 51; Brown, Indian Wars and Pioneers of Texas, pp. 374-375, 589-590; Biennial Report, 1896, ?. 31; Biennial Report, 1898, p. 29. 
Sugarland, actually began his business career as a merchant and builder of the Cane Belt Railway which ran from Sealy to Matagorda, Texas. In 1903, the railroad was sold to the Santa $\mathrm{Fe}$ system. At one time Eldridge owned the City National Bank of San Antonio where he also had other business interests. Eldridge and the Kempner family of Galveston were the principal parties involved in the formation of the Imperial Sugar Company that bought out the Cunningham properties. 41

The last large contractor with extensive land holdings in the sugar growing areas of the state, the Ball, Hutchings Company of Galveston, owned farms in Brazoria County. The firm had been established in 1854 by John H. Hutchings, George Ball, and John Sealy as a dry goods and commission business. Within a year or so, however, the dry goods operation was phased out in favor of private banking. The company made all three men enormously wealthy and enabled them to invest in railroads and other businesses. 42

41 Johnson, Short History of the Sugar Industry, pp. 66-68; Undated Obituary of W. T. Eldridge in Fort Bend County Historical Museum, Rosenberg, Texas.

42 Brown, Indian wars and Pioneers of Texas, pp. 152-159; Biennial Report, 1880, p. 51; Biennial Report, 1882 , p. 36 ; Biennial Report, 1884 , p. 29; Biennial Report, 1886 , p. 36 ; Biennial Report, 1888, p. 28 Exhibits; Biennial Report, 1890, p. 56; Biennial Report, 1892, P. 29; Biennial Report, 1894, p. 31, Biennial Report, 1896, p. 31; Biennial Report, 1898, p. 29. 
The men who hired the labor of state prisoners to develop the sugar industry in Texas exerted a powerful influence on prison system policies for reasons other than their collective wealth. Since more prisoners by far worked on sugar farms than at any other type of outside labor, the men who owned those farms could demand that their voices be heard in Austin during any executive or legislative deliberations concerning penitentiary matters. The contractors must have recognized that their use of prisoners on the cane plantations represented a rather substantial source of revenue to the state, therefore entitling them to some consideration from elected officials. And since the low-cost labor was so vitally important to the continued well-being of the sugar industry, one can only assume that the growers worked together harmoniously to make certain the outside contract system endured.

Although the sugar growers formed the largest and most significant bloc of prison contractors, other wellknown figures also profited from the labor of state prisoners. Two of the more prominent of this group were Thomas S. Henderson and Albert S. Burleson. Both of these men enjoyed long political careers and ultimately occupied positions of considerable influence in state affairs.

Thomas S. Henderson, who leased state prisoners 
between 1906 and 1912, was an attorney from Cameron, Texas. He was admitted to the bar in 1879 and served successively as county attorney and district attorney in Milam county. He also represented the county in the House of Representatives of the Twenty-third Legislature, which met in the spring of 1893. Governor Culberson appointed Henderson to the board of regents of the University of Texas in 1895. He remained on the board for sixteen years and for over ten years was its chairman. 43 The length of Henderson's tenure as a university regent speaks adequately of the quality of his political connections.

Albert Sidney Burleson carried even more political weight than Henderson. Originally from San Marcos, Burleson attended both Texas $A \& M$ and the University of Texas. He was admitted to the state bar in 1884 and began his political career as Austin city attorney. Burleson went on to represent the Ninth Texas Congressional District from 1899 to 1913, and from 1913 to 1921 served as Postmaster-General of the United States. 44

43 Members of the Legislature, 1846-1939, p. 154; Johnson, Texas and Texans, 4: 1664-1665; Hardy and Roberts, Historical Review of South-East Texas, 2: 740; Biennial Report, 1906, p. 28; Biennial Report, 1908 , p. 31; Biennial Report, 1910, p. 35 .

${ }^{44}$ Seth S. Mickay and Odie B. Faulk, Texas After Spindletop (Austin: Steck-Faughn Company, 1965), p. 38; Walter Webb, editor-in-chief, Handbook of Texas, vol. I (Austin: The Texas State Historical Association, 1952): 
Beginning in the mid-1890s, Burleson and his brother-in-law, C. D. Johns, operated a 3,000 acre share farm in Bosque County, using a large labor force of approximately one-hundred fifty state prisoners. The shares on the farm were divided so that the state received 60 percent of the crop. The farm provided a substantial source of income for the owners. 45

Events in the summer of 1900 demonstrated very clearly the value of the farm to Burleson and Johns when, for a time, it appeared their contract for the prison work force might not be renewed. Burleson contacted $E$. M. House and stressed that a termination of the labor agreement with the prison would do him "irreparable" financial damage. He asked House to intervene with the prison authorities to see that the contract be continued. Burleson emphasized that he had been faithful to the administration in Austin and, therefore, was entitled to favorable consideration. He spoke in no uncertain terms of the "great injury" he would suffer if the prison work force were taken from him. 46 House, possibly fearing a breach in

248-249; Adrian Norris Anderson, "Albert Sidney Burleson: A Southern Politician in the Progressive Era," (Ph.D. dissertation, Texas Tech University, 1967), pp. 1-39, 127-128.

45 Anderson, "Albert Sidney Burleson," pp. 40, 56; Biennial Report, 1902, p. 38.

46 A. S. Burleson to E. M. House, July 6, 1900, Roll \#109, House Papers. 
the solidarity of his organization if Burleson was not placated, acceded to the congressman's wishes and the contract was renewed. Burleson, deeply grateful to House for the assistance, kept his prison force until all such contracts ended in 1912.47

In addition to the private individuals who contracted for the labor of prisoners, several railroads also took advantage of the state's prison policies to avail themselves of a relatively inexpensive, dependable supply of labor. For reasons already discussed, state officials did not like to make contracts with the railroads, but did so despite their misgivings as they were a source of revenue and provided a means to keep prisoners busy. As a resuit, there were always a few inmates detailed to railroad construction trains and wood-cutting forces.

During the time span of this study, a total of twenty-one different railroad companies made use of Texas prisoners for varying lengths of time. The twenty year period from 1880 to 1900 saw the most extensive activity. During this period railroads laid sufficient track in

47 Burleson to House, July 23, 1900, Roll \#109, House Papers; Biennial Report, 1896, p. 32; Biennial Report, 1898, p. 21; Biennial Report, 1900, P. 29; Biennial Report, 1902, P. 38; Biennial Report, 1904, p. 38; Biennial Report, 1906 , pp. 27-28; Biennial Report, 1908, P. 32; Biennial Report, 1910, p. 35; Annual Report, 1911, p. 32 . 
the state to establish Texas as the national leader in total railroad mileage. 48

Despite the considerable amount of railroad construction during the last two decades of the nineteenth century, only a relatively small number of state prisoners engaged in such work. On average, the railroads used only 215 prisoners per year in the period 1880 to 1900 . This figure stood far below the number hired by the large planters in the coastal counties. 49 Perhaps because they employed such a relatively small share of the available prisoners, no indications could be found that the railroads exerted any significant pressure to maintain existing prison contracting policies.

The influence of the major employers of prison labor and their willingness to step forth and guard their privileged position account, in large part, for the durability of the contract system. The large landowners and entrepreneurs joined with those political forces in the state that sought to maintain a status quo in which their

${ }^{48}$ Spratt, The Road to Spindletop, pp. 32-33.

49 Biennial Report, 1880, p. 51; Biennial Report, 1882 , p. 36-37; Biennial Report, 1884 , p. 29; Biennial Report, 1886 , p. 36; Biennial Report, 1888, p. 28 Exhibits; Biennial Report, 1890, p. 19; Biennial Report, 1892, p. 29; Biennial Report, 1894, p. 32; Biennial Report, 1896, p. 31; Biennial Report, 1898, p. 29; Biennial Report, 1900, p. 29; Biennial Report, 1902, p. 38; Biennial Report, 1904, p. 38; Biennial Report, 1906, pp. 27-28; Biennial Report, 1908, p. 31; Biennial Report, 1910, p. 35 . 
mutual interests could be protected and extended. The strength inherent in such a coalition made reform of the prison system exceedingly difficult.

The host of individuals who staffed the prison and administered policy joined with the forces resisting change. Most prison employees, especially at the upper management levels, were chosen because of their political record and the promise of continued political support. Such people brought little professionalism to the task of administering the rules and regulations. Those very few who argued sincerely for substantive reform found themselves hopelessly outnumbered by the comparative multitude who viewed their selection for prison employment as a reward which carried with it the understanding that one should not upset the established order. This combination of entrenched privilege and bureaucratic inertia did not begin to come apart until the serious attacks leveled against it early in the twentieth century by various forces that coalesced to demand genuine reforms in penitentiary management. 


\section{CHAPTER VII}

\section{THE END OF LEASING}

As Texas entered the twentieth century, it had undergone many changes in the years since the end of the Civil war. In addition to a sizable increase in population, the growth of urbanization, and diversification of the economy, the state also underwent a political transformation of sorts. The traditional conservatism of the Bourbon Democrats in the 1870 s and 1880 s gave way in the 1890 s to a moderate reform impulse, elements of which carried over into the first decade of the new century and created a political and social milieu that fostered further reforms.

The nature of this reform movement, the forces which composed it, and its effect on prison policies will form the focus of this chapter. An examination will be made of the influence exerted by splinter political parties and factions that forced the dominant Democratic Party to accommodate and compromise with the groups demanding change. Those reform-minded persons and orgarizations that acted independently of any obvious political affiliations will be scrutinized also to 
determine the role they may have played in developing a climate in which change became possible and desirable. In the course of looking at the forces which advocated changes, it will be useful also to examine the public attitudes and assumptions that tended to thwart or delay reforms. Popular perceptions of convicted felons and of the appropriate treatment for such persons undoubtedly contributed, at least in some measure, to an apparent public apathy to prison conditions. Such indifference logically coincided with the interests of those who wished to see the status quo in prison affairs remain unaltered. Public attitudes toward taxation and state spending for public institutions also must be considered as a factor in prison reform. Since the abolition of the contract system involved not only additional outlays for prisoner care but a loss of a substantial amount of income as well, elected leaders of the state had to move slowly and cautiously to avoid any irrevocable action that would not be supported by the voters. The fact that the public ultimately came to accept an end to the practice of hiring out prisoners to private individuals attests to the magnitude and intensity of the reform movement.

In looking at the forces that sought to bring about changes in the administration of the state's prisons, it is necessary to differentiate between those 
which exerted a relatively minor influence and those which exhibited more substantial and, therefore, effective power. of the former, it can be said that they spoke first in behalf of prisoners and showed great persistence. What they lacked in terms of power to affect change they made up for in perseverance. The group of less influential advocates for prison reform included various voluntary associations such as a prison reform society, women's clubs, organizations of racial minorities, and organized labor unions.

The Prison Reform Association of Texas came into existence in the early 1870 s thanks primarily to the efforts of the Reverend B. A. Rogers, Rector of St. David's Episcopal Church in Austin from 1866 through 1874. Originally from Philadelphia, Rogers came to Texas sometime shortly after the Civil war to help the state's citizens recover from the wounds of the conflict. He became active in a number of charitable efforts and in 1872 attended the first meeting of the International Prison Congress, held in London. Upon his return from England, Rogers organized the Prison Reform Association and persuaded a number of lawyers and legislators to join. ${ }^{1}$

${ }^{1}$ Federal Writers Project of Texas, St. David's Through the Years (Austin: St. David's Guild, 1942), ?. 49-49; Proceedings of the National Prison Association, pp. $6 \overline{6-67,104-105 . ~}$ 
During the spring of 1873, the Prison Reform Association of Texas petitioned the state legislature for action. Evidently, however, the poor financial condition of the state left little money available for serious reforms of eleemosynary institutions. Indeed, the state treasury needed the revenue from the Ward, Dewey lease. Another problem besetting Rogers and his group in their reform efforts was an apparent inability to focus their attention clearly on the state prison. In a memorial to the legislature in January, 1873, for example, the organization urged state action to improve the county jails, especially the one in Austin. It made no mention of the prison. A subsequent letter to the lawmakers included the subject of prison problems with appeals for mercy for two condemned murderers in the Travis County jail, a request for a state poorhouse, and a house of correction for juvenile offenders. Possibly, had the Prison Reform Association restricted its efforts solely to seeking improvements in the state prison and tried to come up with some alternative sources of income for the institution, it might have been more successful in its program. 2

\section{2 "Memorial of the Prison Reform Association of} Texas. To the Legislature of the State of Texas, January 23, 1873," Texas State Archives and Library, Austin, Texas; Austin Daily Democratic Statesman, March 15, 1873, p. 2. Roger's efforts to get a new jail for 
In late December, 1874, because of poor health, Rogers resigned his position at St. David's and left Austin. He lived on a ranch in Williamson County for several years and moved finally to Houston, where he died in 1904. Although he remained active in the cause of prison reform until his death, the Prison Reform Association which he founded disappeared after he left Austin. ${ }^{3}$ Other early criticism of existing prison policies came from leading members of the black community in the state. No doubt because blacks made up such a disproprotionate share of the prison population, black leaders scored not only prison conditions but also the inequities in the legal system that left minorities at the mercy of white judges and juries. The net effect of the protests from the black community, like those from the Prison Reform Association, was nil.

It should be noted that some division of opinion existed among blacks regarding state prison policies. Some persons spoke out against the large numbers of black citizens in the prison system and the types of

Austin reached fruition in 1876 when "one of the State's most modern jails" was constructed in the city. Federal Writers, St. David's Through the Years, p. 48.

3 Frank Brown, "Annals of Travis County and of the City of Austin from Earliest Times to Close of 1875," vol. 13, 2. 71, Austin Public Library, Austin, Texas; Proceedings of National Prison Association, 1897, pp. 66-67, $104-105$. 
labor to which they were put. Others pronounced themselves satisfied with the way in which the prisoners were treated. It seems likely that most black Texans disliked state prison policies, but the issue was not one of universal importance to them. Rather, they listed it as one of many grievances in support of improving their position in Texas society. As early as July, 1879, in a conference in Houston, black leaders from around the state gathered to air common grievances and discuss the wisdom of leaving the state and joining the exodus to kansas. In the course of their meeting no reference was made to prison policies as a source of dissatisfaction. Conference members objected specifically to discrimination in railroad travel, the lack of a good public school system in the state, and the generally superior attitude manifested by whites toward other racial groups. The absence of any mention of prisons, however, should not be taken to mean that blacks in the state did not object to the relatively large numbers of their race incarcerated. One black farmer who joined the exodus to Kansas complained that he did so, at least in part, because so many of the young people were being "sent to the penitentiary and hired out on sugar farms," and he Eeared the situation would get worse. Probably, the omission of the prison from the list of conference concerns simply reflected the fact that other matters were considered more important and in greater need of 
immediate attention. ${ }^{4}$

The most forceful statement of black opinion regarding the prisons came during a state convention of black citizens held in Austin in July, 1883, shortly after the termination of the leases of the state prisons. The committee on grievances at the convention drew up a list of five complaints it wished to bring to the attention of the elected leaders of the state. The five areas of dissatisfaction and the order of rank in which they were listed included opposition to the state's miscegenation statutes, criticism of funding shortages for black public schools, complaints against the manner in which state prisoners were treated, criticism of the broadlyaccepted policy of denying to black citizens equal access to the services provided by railways, inns, and taverns, and opposition to the exclusion of blacks from jury service. 5

${ }^{4}$ Galveston Daily News, July 3, 1879, p. 1; July 4, 1879, P. 1; T. Michael Parrish, "A New Species of Slavery," unoublished paper delivered at the Fall meeting of the East Texas Historical Association, September 27, 1980, Nacogdoches, Texas.

5 Herbert Aptheker, ed., A Documentary History of the Negro People in the United states (New York: The Citadel Press, 1951), pp. 686-691. The priority given to the opposition to the state's miscegenation laws stemmed Erom a disagreement with the fundamental social assumption underlying such laws. Black leaders believed that the penalties for miscegenation manifested a deeply-held conviction by whites of the social inferiority of blacks. In the opinion of the convention, all discriminations against blacks by white Texans derived from the social attitudes inherent in the laws against intermarriage between the races. 
With specific reference to prisons, the convention did not condemn the contract system totally, or publicly favor its abandonment. It did, however, criticize the manner in which the prisoners on the farms were treated as compared with the generally good conditions inside the walls. Protests were directed at the brutal conduct of the guards and the excessive amounts of work required of the prisoners. Complaint also was lodged at the lack of any reformative efforts in the outside camps. To remedy the situation, the convention called upon state leaders to appoint a black inspector of outside prison camps to make certain all rules and regulations were followed according to the spirit and letter of the law. Elected officials also were urged to appoint at least one black man to the board of prison commissioners. Presumably, black inspectors and commissioners would safeguard the interests of black prisoners more diligently than did their white counterparts. 6

No blacks received appointment to prison service during the period of this study. In part, the reason for such an omission lay in the assumptions by whites of black inferiority, the very attitude castigated by the members of the 1883 convention. In addition, however, the political nature of penitentiary appointments probably excluded

${ }^{6}$ Ibid., pp. 687-690. 
blacks from serious consideration. Since blacks in the late nineteenth century were diminishing rapidly as a political force, they also were losing any rights of patronage, such as to prison jobs.

A year or so after the 1883 convention in Austin, a black member of the legislature spoke at some variance with the earlier charges made against the prison. R. J. Moore, who represented Washington County in the House of Representatives of the Eighteenth, Nineteenth, and Twentieth Legislatures, served in 1885 as a member of a legislative committee examining the prisons. The investigation found nothing seriously amiss in prison management and had much praise for the leadership of Superintendent Goree. Following the investigation, Representative Moore pronounced himself "perfectly satisfied with the treatment of colored prisoners." 7

It is difficult to reconcile Moore's statement with the criticisms of the 1883 convention, or with the conditions that were known to have existed in the outside camps. It might have been that although life in the camps proved indeed hard and difficult to endure, it seemed no harder on black prisoners than on any others. All farm inmates may have been subjected to the same deplorable

${ }^{7}$ Dallas Weekly Herald, February 19, 1885, p. 2; Members of the Legislature, 1846 to 1939, pp. 113, 122, 129 . 
treatment with no distinctions made because of race. Possibly the investigative effort in 1885 confined itself solely to the Huntsville and Rusk facilities with no visits at all to the outside camps. Since everyone agreed that conditions inside the two prisons appeared measurably better than those in the contract camps, the more likely explanation for Moore's comments would be that the committee visited no camps. 8

The early efforts by the prison reformers and black leaders to focus public attention on the prisons failed to generate any substantive response. They own the distinction of having spoken out first but received little reward for their initiative. The forces resisting change were simply too formidable and imposing to yield to groups that stood clearly outside the mainstream of public opinion.

The average Texan in the latter decades of the nineteenth century apparently thought very little about the persons serving time in the state prisons. Most people were too busy with their own problems to give

Eepresentative Moore was himself a former inmate in the Texas prison. He had served time for attempted murder in the early 1870s. Upon expiration of his sentence he was given a full pardon by Governor Davis and had all the rights of citizenship restored. Moore was well liked by his colleagues in the legislature and his prior experience in the prison no doubt enabled him to see beyond any attempts at cover-up or sham and get a true picture of conditions. Galveston Daily News, Feburary 23, 1885, p. 1 . 
much attention to convicted felons incarcerated in geographically isolated institutions. On those relatively few occasions when the public did speak out about prisoners it criticized state leaders for allowing proven lawbreakers, persons who had presumably demonstrated their contempt for society, to work outside the prison, thereby depriving honest citizens of needed jobs. The lack of public concern for conditions in the prisons goes far toward explaining how the system could deteriorate to the deplorable levels uncovered by the investigation of $1909-1910$.

Public apathy toward the prisons and the general ignorance of prison conditions existed almost from the inception of the lease period. Shortly after the beginning of the Ward, Dewey lease, an editorial in a leading newspaper of the state lamented the general lack of interest in prison affairs.

Our people are too much in a hurry in the modes of their own life to bestow earnest and well-digested thought upon the . . effects of. . penal justice, and the duty of adopting reformation measures in behalf of condemned criminals. 9

The several former prisoners who wrote of their time spent in Texas prisons also mentioned the prevailing level of ignorance about the prison among the public at large. Indeed, the very fact that the former inmates

${ }^{9}$ Galveston Daily News, May 4, 1873, p. 1. 
felt compelled to describe their experiences in print indicated their belief that most people did not know much about prison life and the conditions under which the inmates lived. J. L. Wilkinson wanted to "burn... into the minds of the people" of Texas the terrible ordeal suffered by prisoners. If people knew how bad things truly were, changes would come. Henry Tomlin wrote that the disgraceful conditions in Texas prisons would change only when the public became informed fully of the vile nature of prison life. Charles Campbell warned Texans that their state would continue to suffer rebuke and scorn from other parts of the nation, "until the sure enough civilized of this state take closer notice of what is going on here [in the prisons] and devise means for a general cleaning out of officialdom. . . . "l0

Unfortunately for those who urged reform, some people did pay attention to prison conditions but the feelings they expressed toward any significant change were inhospitable. Shortly after the establishment of the Prison Reform Association, an outcry went up against all the "talk about prison reform in this country," that would make prisoners "the subject of fashionable sympathy."

10 Wilkinson, The Trans-Cedar Lynching, p. 95; Tomlin, Henry Tomlin, p. 251; Campbell, Hell Exploded, ?. 11 . 
Prisons ought not to be made desirable, nor criminals glorified as martyrs to cruel laws. A prison, at best, should be an object of horror, that men may be deterred from the commission of crime by the fear of getting in it.11

The opponents of the prison reformers conceded that prisoners deserved "a sufficiency of plain food and comfortable clothing," and should not be treated cruelly. Beyond these basic needs, however, they were not willing to go. 12

The belief that the prisons should not be places of comfort also enjoyed currency among some of those citizens most vehement in their objection to the lease and contract systems. John N. Henderson, a judge of the Court of Criminal Appeals in Austin, emerged as a prominent prison reformer in Texas in the late nineteenth century. Exhibiting the most enlightened approaches to penology of the age, Henderson abhorred the practice of hiring state prisoners to private parties and wanted all inmates under exclusive control of the state so that the full array of reformative influences could be provided. He disagreed vigorously, however, with those "sentimentalists who would scatter his [prisoner's] pathway with roses. . ." Addressing a meeting of the National Prison Association in 1897, Henderson argued,

\footnotetext{
${ }^{11}$ Austin Daily Statesman, July 17, 1873. 12 Ibid.
} 
The treatment of the convicted felon should be humane, but firm; his labor should be arduous and his treatment and discipline so severe that he would forever dread the prison walls. His punishment should not only be a deterrent as to himself, but it should be such as to deter others.13

Much of the animus for making prisons as uncomfortable as possible arose from the belief that convicted felons, because of their transgression of society's laws, were not entitled to undue concern for their creature comforts. Upon their conviction, prisoners lost the right to expect anything other than what society chose to give them. The popular mind considered prison inmates as outside all but the most minimal levels of compassion. Such feelings provided the rational underpinnings for the "convict bogey" apparition that saw prison inmates as loathsome, dangerous creatures who, for the safety of honest citizens, had to be kept locked up and out of sight. 14

One Texas prisoner, travelling to Huntsville in the custody of the state transport contractor, described the attitude of free citizens sharing the same railroad car. People stared at the recently-convicted felons and no one made any attempt to start conversation. The prisoners were regarded "as wild beasts" whom the public wanted watched "with sufficient care as to preclude the

13 Proceedings of National Prison Association, 1897 , pp. $303-304$.

$$
14 \text { Ailen and Simonsen, Corrections in America, p. } 63 .
$$


possibility of escape." An individual in the prison system was "despised" and denied any "sympathy" from citizens "outside of the world at large."15

The most graphic example of the hostility and contempt exhibited by some members of society toward state prisoners occurred in early summer, 1879, when passengers on a train in northeast Texas witnessed the shooting of a young prisoner who had attempted to escape from a railroad construction crew. After the shooting, the guard dumped the young man, still alive, at a "shanty to rot and die." Some of the onlookers were appalled at such a display of callousness; others, however, simply shrugged their shoulders and said, "he is nothing but a convict."16

The public perception of prison inmates as objects of scorn made the task of the reformers doubly difficult. As long as a sizable segment of society remained unwilling to grant to the prisoners a degree of humanity, it was impossible to make any serious assault against leasing. The problem became compounded even further when people recognized that an increase in taxation likely would ensue if the state attempted to reform the prison by ending contract labor.

15A. L. George, The Texas Convict: Thrilling and Terribie Experiences of a Texas Boy (Austin, Texas: Ben C. Jones and Company, Printers, 1893), pp. 105, 115. ${ }^{16}$ Austin Dailv Democratic Statesman, May 2, 1879. 
Texans of the late nineteenth and early twentieth centuries enjoyed relatively low levels of taxation. The state had never had a strong tradition of spending for public institutions and the fiscal distress ushered in by the collapse of the Confederacy did little to alter longstanding customs. Texas citizens seemingly preferred reductions in public services if necessary to maintain the low taxes. 17

Prior to 1860, state income came primarily from the sale of indemnity bonds. Additional operating funds became available to state officials in the form of the five million dollars Texas received as part of the Compromise of 1850. Although the state levied taxes on both real and personal property, on occupational licenses, and for use of the polls, confused and poorly administered assessment and collection procedures caused little revenue to be generated. In 1860, for example, from a free population of approximately 420,000 persons, the total tax receipts of all taxing jurisdictions in the state came to only $\$ 533,265.18$

The reconstruction governments in Texas, especially the administration of the Republican E. J. Davis, 95-97.

${ }^{17}$ Miller, Financial History of Texas, pp. 18-26, ${ }^{18}$ Ibia., pp. 107-113. 
met considerable hostility, primarily from Democrats, toward state spending for education, transportation, and law enforcement. Notwithstanding the positive intentions of the Republican programs, or the benefits that likely would have accrued from them, many citizens thought they were too costly and concentrated too much power in the hands of the governor. Critics of Governor Davis and his party wasted little time in voicing their objections to his policies. 19

In late September, 1871, opponents of the Republican program met in a protest convention in Austin. Calling themselves the Taxpayer's Convention of the State of Texas, the assembled delegates claimed to speak for the citizens of ninety-four Texas counties. Although the convention stated that it represented "no particular political party" and would tolerate "no partisan discussion," it demonstrated a rather obvious political bias against Davis and his brand of Republicanism. 20

Convention members scored the Republicans for

\section{Moneyhon, Republicanism in Reconstruction}

Texas, po. 129-167.

${ }^{20}$ Proceedings of the Tax-Payers' Convention of the state of Texas, held at the City of Austin, September 22,23 , and 25, 1871. Also a Memorial to the Legislature, and an Address to the Tax-Payers of Texas (Galveston: News Steam Book and Job Office, 1871), pp. 5-11. Future prison commissioner Walter Tips, chosen as one of two assistant secretaries of the convention, represented Comal County, and Thomas Goree spoke for Madison County. 
recent increases in taxation levels that had raised ad valorem property levies from fifteen cents per hundred dollar valuation to $\$ 2.17 \frac{1}{2}$ for the same valuation. The delegates wanted taxes reduced to one-third of one percent for state needs and one-half that amount for county purposes. Obviously, in calling for such drastic reductions in state income, Davis' opponents contemplated a much smaller and less expensive state government. 21

Because of the ease with which taxes could be evaded the Republican taxing system ultimately failed to accomplish its goals. The state had to sell bonds to obtain operating revenue, thus increasing the debt. More importantly, however, the experience under the Davis administration further fastened in the minds of a majority of citizens the conviction that taxes should be kept as low as possible and state spending regulated accordingly. Low taxes and limited state government became articles of faith for the Democratic Party when it recaptured control of the legislature in 1872 and the statehouse in $1874 .^{22}$ With their return to power in the 1870s, Texas Democrats maintained their control of state politics

$$
\begin{aligned}
& 21 \text { Ibid., pp. 21-23. } \\
& 22 \text { Miller, Financial History of Texas, pp. } 166 \text {, }
\end{aligned}
$$
193; Roscoe C. Martin, The People's Party in Texas. A Study in Third Party politics (Austin: University of Texas Press, 1970), p. 18 . 
throughout the remainder of the century and the period covered by this study. Uninterrupted Democratic rule, however, did not mean that the party enjoyed complete unity. On the contrary, splinter groups and factions arose during the late nineteenth century to challenge majority policy within the Democracy and force it to accommodate divergent interests. 23

Demands for change in the shape of government appeared very shortly after the Democratic Party returned to power in the state. Disgruntled agrarian elements among the population, suffering the financial distress that accompanied the economic panic of 1873, spoke out first. That farmers should have taken the lead in seeking political reform comes as no surprise given their strength in Texas society at the time and the problems they were suffering. In 1870, approximately 70 percent of the state's population engaged in some form of agriculture or an occupation related to agriculture. This number remained fairly constant and by the turn of the century had dropped by only five percentage points. Through the latter decades of the nineteenth century, farmers endured falling prices, growing indebtedness, increasing dependence on middlemen, and railroad rates that the producers considered to be too high. All of these problems combined

23 Martin, People's Party in Texas, pp. 16-21. 
to convince the farmers that powerful combinations of monopolistic capital were conspiring to reduce the agricultural classes to a state of peonage. 24

Through the last quarter of the nineteenth century, farmers increasingly turned to politics as a means of improving their position in society. The state constitution ratified in 1876, with its provisions for extreme retrenchment in government spending and services, accurately reflected the efforts of the large agrarian element that had authored it. Following the adoption of the constitution, Texas agriculturalists actively entered the political life of the state, hoping to maintain their view of the proper function of government. 25

During the 1880s, first the Greenback Party and then the Farmer's Alliance took up the cudgel in behalf of the state's agricultural classes. The Greenbackers, who first began to organize in the state in 1876, favored expansion of the currency by incorporating into the money supply greenbacks in amounts equal to treasury notes then

24 Moneyhon, Republicanism in Texas, pp. 194-196; Barr, Reconstruction to Reform, pp. 176-192.

25 Barr, Reconstruction to Reform, pp. 9-10; Seth Shepard McKay, seven Decades of the Texas Constitution of 1876 (Lubbock: Texas Technological College Press, 1942), PP. 47-48, 68-70; Wallace, Texas in Turmoil, pp. 226-227; Ralth A. Smith, "The Grange Movement in Texas, 1873-1900," The Southwestern Historical Quarterly, 42 (April 1939): 298 . 
in circulation. They opposed the demonetization of silver, land grants to railroads and corporations, and state taxes on occupations. The party also favored the idea that - . the honest mechanic and laborer of the country should not be forced into competition with gangs of convicts sentenced to penitentiaries for crimes and we demand that the contract system for this class of labor shall be abolished, and that all convicts shall be confined within the prison walls.26

The Greenbackers entered candidates in state political races in the late 1870 s and early 1880s, but despite some early successes, by 1884 the party was fading from the political scene. 27

The Farmer's Alliance, which had appeared originally in the 1870s, enjoyed a major resurgence of strength in the mid-1880s. Although the Alliance did not run its own candidates for office, it threw its political support to those office seekers who demonstrated sympathy for farmers. Alliance members favored railroad regulation and adoption of the subtreasury plan, and opposed convict leasing. The Alliance's position on lease came about as part of an effort to broaden its base of support by reaching out to groups, like labor, with which it felt a

${ }^{26}$ Roscoe C. Martin, "The Greenback Party in Texas," The Southwestern Historical Quarterly, 30 (January 1927): 161-168.

27 Ibid. 
commonality of interest. 28

Joining the farmers in the opposition to leasing came the Republican and Prohibition parties. At its 1882 state convention, the Republican Party, containing a large percentage of blacks, wanted all prisoners confined within the walls of the prisons. Party members said nothing concerning any type of work the prison inmates should do, or that they be self-sustaining. In addition, Republicans favored the establishment of "houses of refuge or correction for juvenile offenders." 29

Six years later, the Prohibition Party, which had been established in 1884, called for abolishing the practice of hiring prisoners to private contractors. The party favored placing all inmates within the walls of the prison. Like the Republicans, the Prohibitionists made no mention of having the prisoners work to sustain the

${ }^{28}$ Martin, People's Party, pp. 21-19; Barr, Reconstruction to Reform, pp. 93-110. The subtreasury idea called for the establishment of sub-treasuries, or branches of the treasury, throughout the country. In conjunction with the subtreasuries there would be government warehouses where farmers could store farm goods until prices improved. Robert C. McMath, Jr., Populist Vanguard. A History of the Southern Farmer's Alliance (New York: W. W. Norton and Company, Inc., 1975), pp. 90-91.

29 Barr, Reconstruction to Reform, pp. 180-192; Ernest William Winkler, ed., Platforms of Political Parties in Texas (Austin: Bulletin of the University of Texas, No. 53, 1916), p. 213. 
prison operating costs. 30

By 1890, the agricultural classes in Texas prepared to enter what would be a very active decade for them. In that year, Texas agrarians enthusiastically supported James Stephen Hogg, who campaigned for governor on a platform calling for a state commission to regulate railroads. Following Hogg's lopsided victory over his opponents, elements of the farmer constituency broke with the governor over disagreements as to the membership of the regulatory body and the manner in which commission members were to be selected. The disaffected farmers provided the nucleus around which the People's Party in Texas would be built. 31

Texas Populists formed the strongest of the farmer movements in the state. They supported the objectives of their parent organization at the national level, especially the incorporation of silver into the currency base, and tighter controls over railroads. They also favored property tax revision, a graduated income tax, and significant

${ }^{30}$ Barr, Reconstruction to Reform, pp. 85-93; Winkler, Platforms of Political Parties, p. 255.

31 Barr, Reconstruction to Reform, pp. 117-121; Martin, People's Party, pp. 26-27. On the subject of prison labor, Hogg came up with the novel idea of having state prisoners manufacture the same goods as those produced by the trusts and monopolies operating in the state. Nothing ever came of the suggestion as the state had decided to emphasize outside farm labor over manufacturing in the prisons. Robert C. Cotner, James Stephen Hogg: A Biography (Austin: University of Texas Press, 1959), p. 225. 
salary reductions for all government officials. 32

Drawing on the experience of the Alliance, Texas

Populists encouraged others to join their movement. They incorporated into the various party platforms provisions designed to broaden the base of popular support, particularly among workers. For wage laborers, the party sought an eight hour workday, the creation of a state bureau of labor and board of arbitration, and a prohibition against arresting unemployed workers for vagrancy. They also sought to remove convict labor from competition with free workers. 33

The populist appeal found ready converts in Texas. Party membership grew dramatically, and by early 1892, over 2,000 Populist clubs had been formed around the state. Two years later, the populist candidate for governor polled 160,000 votes out of a total of 376,000 cast.

32 Martin, People's Party, pp. 47-52.

${ }^{33}$ Ibid., p. 53. One has reason to question the sincerity of the Populists in calling for an end to competition with prison labor. At the same time that the party appealed for the votes of free workers, it also advocated using state prisoners to build a publicly-owned railroad to run from the Gulf of Mexico to the Red River and open the central parts of the state. Party ambivalence on this issue mirrored the activities of party members in other parts of the country who, while condemning the competition from prisoners, nevertheless urged that convicts be used to build roads. Dan T. Carter, "Prisons, Politics and Business: The Convict Lease system in the Post-Civil War South" (M.A. thesis, University of Wisconsin, 1964), ?. 98. 
In the same balloting, the party elected twenty-two representatives and two senators, an impressive number but not enough to control legislation. 34

Following the strong Populist showing in 1894, Texas Democrats stole much of the thunder of the third party. In the state convention in the summer of 1896 , the Democrats came out in favor of silver monetization, a graduated income tax, and the direct popular election of United States senators. They registered their opposition to monopoly control and trusts and to existing tariff policies that offered protection to manufacturers but free trade to agriculturalists. The pre-emption of much of the Populist program left it with less to entice voters. Many of the farmers returned to the Democratic Party that had seemingly changed and begun to adopt a reform posture. 35

Populist strength waned quickly in the late $1890 \mathrm{~s}$ and by the turn of the century had ceased to be a formidable factor in state politics. Thus it suffered the customary fate of third parties in Pmerican history. Its failure to capture control of state government, however, is not, perhaps, the best measure of its success. As party members looked back over their struggles in the

\footnotetext{
34 Martin, People's Party, pp. 40-45; Barr, Reconstruction to Reform, Dp. 157-159.

${ }^{35}$ Barr, Reconstruction to Reform, pp. 161-172.
} 
1890 s they could point with justifiable pride to the changes they had wrought in state politics. The Democratic Party of the Bourbons that had practiced an extreme form of limited government and fiscal retrenchment to the point of parsimony had yielded its control and philosophical orientation to a new generation of political leaders flexible enough to permit an expansion of government to meet the needs of a maturing state. 36 Although the farmer groups had managed to bring about fundamental alterations in the outlook of the dominant Democratic Party, they had wrought little change in the party's position toward placing state prisoners in contract labor camps. As early as 1878, Democratic platform writers had deprecated the necessity of keeping state prisoners outside the walls of the prisons and had urged an end to such practice "as soon as practicable." These practical considerations remained of supreme concern to the party throughout the state contract period. In 1894, state Democrats condemned the hiring of prisoners to "corporations and private individuals," and wanted the practice stopped "at the earliest practicable moment consistent with the best interest of the State." By 1902, the party had come to

${ }^{36}$ Martin, People's Party, pp. 266-267. 
favor the enactment of laws providing for the employment, as far as practicable, of shorttime state convicts on the public roads in counties making suitable provisions therefor, and the employment of state penitentiary convict labor on work not in competition with free labor, as far as practicable, and that such prisoners be employed in the walls of the penitentiary and on farms operated by the state on its own account. 37

It appears that money matters formed the major concern of Democratic officials with regard to prisons. To have ended outside contracts would have required heavy expenses to make up for the lost income. This did not seem "consistent with the best interest of the state." As the People's Party spent itself late in the 1890s, state politics went through a hiatus of reform. The two governors who served during the 1898-1906 period, Sayers and Lanham, were both ex-Confederates and conservative Democrats who concerned themselves primarily with cooling political tempers and reuniting the Democratic Party. Both men owed and acknowledged much of their electoral success to the organization built and run by Edward House, who persistently shied away from any political or legislative innovations that would tamper seriously with the existing governing apparatus. House and his people, although not opposed to all changes, manifested a much more favorable attitude toward business and political stability. They used their considerable

37 Winkler, platforms, pp. 185, 341, 448 . 
powers over patronage to ensure that people of similar philosophy received appointment to state jobs. ${ }^{38}$

Despite the seeming placidity of state politics at the turn of the century, however, the spirit of reform and the desire for changes to improve society remained alive. During the Sayers-Lanham regnum new groups that sprang from Texas towns and cities and from the industrial establishments in the state joined with the remnants of the agricultural movement of the last quarter of the nineteenth century to throw their weight into a new march of progressivism. In the 1906 gubernatorial elections, the revived reform forces coalesced behind the candidacy of Thomas M. Campbell, who appeared to promise a break with the business-as-usual government of the preceding eight vears. 39

Campbell opened his campaign for the Democratic nomination with a speech in Athens on April 21, 1906. The tone of the address hinted at the kind of administration he hoped to lead. More importantly, Campbell couched his appeal for votes in terms he believed would attract

${ }^{38}$ Barr, Reconstruction to Reform, pp. 220-222; Lewis L. Gould, Progressives and Prohibitionists. Texas Democrats in the Wilson Era (Austin: University of Texas Press, 1973), pp. 11-15.

${ }^{39}$ James Aubrey Tinsley, "The Progressive Movement in Texas" (Ph.D. dissertation, University of Wisconsin, $1953)$, D. 66 . 
the largest percentage of voters. 40

Early in his talk, Campbell described for his listeners the forces in the state that sought to keep him out of the governor's chair. According to the candidate, he was fighting against

Those who would debauch popular government and make it the instrument of avarice and greed, who would make our constitution the toy and the plaything of monopoly, our laws the hiding places of trusts and the shield of grafters, and those who would make Texas only a 'breeding ground for more millionaires and more paupers. . . 141

He warned the crowd that "organized corporate wealth" sought "to fasten its iron hold" upon state government while, at the same time, the trusts were "forging their merciless shackles upon the industry and energies of the people of this commonwealth. . . " Campbell expressed his pleasure that the citizens of Texas, aware of the pernicious actions of great wealth, were "again manifesting a disposition to take an active and firm hand in public affairs [so] that present evil tendencies may be checked." He exhorted his listeners to join the fight with him and not permit themselves to be duped by the "corporations and the trusts" who wanted to use "decoy" issues such as

40 Thomas M. Campbell, Speech of Thomas M. Campbell Opening his Campaign for Governor of Texas, at Athens, Texas, Ppril 21st 1906 and Press Comments (Palestine, Texas: Palestine Printing Company, 1906), pp. 3-31. 41 Ibia., pn. 3-4. 
prohibition and local option to divert public attention away from the more legitimate concerns in the campaign. ${ }^{4}$ After making the customary pledge to use the public tax money in an efficient, business-like way, Campbell went on to outline his policies in certain key areas of public affairs. With regard to prisons, he argued that convicted felons should receive "suitable care and humane treatment" from the state. In addition, prisoners "should be required to work, of course, and they should be made self-sustaining." He opposed the use of prison inmates to "enrich individuals and corporations" and called for the abolition of the "system of leasing and otherwise employing convicts in competition with the farmers and wage earners of Texas. . ." 43

As a solution to the prison labor problem, Campbell came out in favor of employing prisoners on the public roads of the state. "Good roads enhance the value of Earms, make life in the country more attractive and increase the trade of the towns and cities." Echoing former Governor Hogg, he suggested that those prisoners confined within the walls of the penal institutions should be put to manufacturing goods to compete with the products offered by the trusts and other monopolistic

$$
\begin{aligned}
& 42 \text { Ibid., N. } 3-9 . \\
& 43 \text { Ibid., pD. 13-14. }
\end{aligned}
$$


concerns operating in the state. Convicted felons, in the words of the future governor, "should never be used to drive free labor from the mines, the factories and Earms of Texas." 44

In other parts of his opening address Campbell spoke in favor of a constitutional amendment to permit counties to levy an ad valorem property tax to support rural schools, those most in need of additional funding. He also graised voluntary associations of farmers and workers established to obtain for their members a more equitable reward for the fruits of their labor. He denied that such associations constituted a type of trust that sought monopolistic control.

Their purposes are for the moral and inteliectual development and the material prosperity of its members and all mankind. Sele preservation and the general uplifting of mankind are inherent in these organizations. 45

Before concluding his remarks, Campbell declared his support for tax revision to ease the burden on small landowners, a graduated income tax, and stricter regulation of railroads. He opposed railroad mergers and consolidations, the issuance of free railroad passes, professional lobbyists, and the occupation tax except for those persons "enjoying special governmental advantages

$$
\begin{aligned}
& 44 \text { Ibid. } \\
& 45 \text { Ibid., pp. } 14-18 \text {. }
\end{aligned}
$$


and franchises. . . " 46

The shopping list of policy statements Campbell presented to the citizens in 1906 demonstrated that protected wealth and special privilege had come a long way toward supplanting the Republican party as the bete-noire of Texas politicians. Indeed, the very fact that he lambasted the monopolies and trusts and made such an open and direct appeal to farmers, workers, and the progressive element among the citizenry suggests the size and power of the anti-corporate bloc in the electorate. Texas voters, sensitized by the agrarian reform campaigns of the last decades of the nineteenth century, joined together in 1906 to renew the reform effort.

The state over which Campbell would preside during his administration had changed considerably since the $1870 \mathrm{~s}$ in areas other than political orientation. The impoverished, heavily-indebted commonwealth of the immediate post-Civil war period had worked its way out of its financial morass and appeared to be relatively prosperous as the twentieth century dawned. The conservative fiscal policies of the late nineteenth century had strengthened the state economy, albeit, and regrettably at times, by neglecting the development of public institutions like schools and charitable agencies.

${ }^{46}$ Ibid., pp. 15-28. 
By the turn of the twentieth century, changes in the state's economy made more money available for public spending. Agriculture, which engaged the attention of well over half the adult citizenry in 1900, had expanded as settlement reached the western areas of the state. Between 1890 and 1900 , the percentage of the state land area committed to farmland increased from 21.6 percent to 74.9 percent, with a corresponding increase in the valuation of farms, lands, and buildings from $\$ 170,468,886$ to $\$ 1,843,203,395.47$

Accompanying the tremendous growth in agriculture came a sizable increase in manufacturing in the state. In 1900, industrial production stood well below that of the farms in the state but had increased some 800 percent since 1870. Lumbering, the processing of cottonseed, and flour milling formed the largest industries at the turn of the century. 48

On January 10, 1901, with the discovery of the large oil field at Spindletop, near Beaumont, the economy of the state entered a new, and more prosperous, era. Opportunists and entrepreneurs converged on the southeast Texas area and sank additional wells to tap into the large underground reservoir. Oil production increased

\footnotetext{
${ }^{47}$ Millex, Financial History of Texas, p. 241. 48 Spratt, Road to Spindietop, ?p. 281-282.
} 
dramatically. From 1,000 barrels per year in the late 1890s, the output grew to 4,400,000 barrels in 1901 and to approximately $21,000,000$ barrels in 1902.49

The growth of the oil industry stimulated the state economy in ways other than just the increase in the number of barrels produced. It boosted urbanization and all the industries associated therewith, brought investment capital into the state, and spurred the development of oil-related products and services. Along with the industrial growth came remarkable increases in bank deposits and tax receipts for state government. During the period 1890 to 1910, the amount of money on deposit in Texas banks increased from $\$ 2,081,000$ to well over $\$ 262,000,000$. State tax receipts during the same period grew from just over $\$ 3$ million to more that $\$ 17$ million. 50 The tremendous economic growth of the late nineteenth and early twentieth centuries made additional funds available for public charitable institutions. State leaders continued to speak of the necessity of curbing expenses and keeping taxes low, yet during the period 1881-1915, the amount spent by the state for social services increased from 36 percent of the total
${ }^{49}$ Ibid., p. 283.
50 Ibid., pp. 282-284; Miller, Financial History of Texas, pp. $242-243,264$. 
expenditures to 82 percent. The fiscal flexibility that came with the increase in tax receipts made it possible for Texas to extend services to all its citizens, even convicted felons and, at least to some degree, made the Campbell reforms possible. 51

The coalition that supported the new governor consisted of a variety of groups, some familiar to the Texas political scene, others relatively new. With specific reference to prison problems, the labor organizations of the state and the genteel reformers of the towns and cities represented the two most important elements. Both of these groups had come into existence as political forces during the late $1890 \mathrm{~s}$ and early $1900 \mathrm{~s}$ and formed a vital addition to those seeking change in prison policies. 52

Although Texas wage laborers as early as the republic period had united periodically to try to correct local disputes in which the $y$ Eelt wronged, only with the

51 Miller, Financial History of Texas, EP. 248-249.

52 It is a matter of some interest that apart from individual actions like those of Chaplain Hodges, the largest religious denominations in the state apparently evinced no concern for prison problems. Southern Baptists and Methodists of turn of the century Texas reserved their re 0 orm energies for campaigns in favor of prohibition, Sabbath observance, and strengthening family life, while opposing gambling, "worldly amusements," and interracial relations. Katherine Brown, "A Social History of Texas Baptists since 1865" (M.A. thesis, Baylor University, 1949); John Daniel Barron, "A Critical History of the Texas Christian Advocate, 1849-1949" (M.A. thesis, University of Missouri, Columbia, 1952). 
arrival of the railroad in the 1870 s did conditions in the state reach a point conducive to the formation of labor unions. The railroads brought with them the labor organizations of railway employees. One of the earliest strikes by these unions, against the Houston and Texas Central in the early summer of 1872 , drew attention to some of the problems of the early unions in Texas but failed to achieve any substantive results. The organizations were too small, too weak, and lacked the dynamic dedicated leadership that could sustain them through times of distress. 53

By the early 1880s, the knights of Labor, one of the early national labor organizations, had begun recruiting among Texas workers. Within a few years, membership had reached approximately 30,000 , a figure that likely included many farm laborers as well as urban workers. Recruiting drives in the state achieved such results that by early 1886 only Boston, Columbus, Ohio, and New York City had larger enrollments in the union. 54

The Great Southwest Strike, a signal event in the history of Texas labor, took place from early March

53 James V. Reese, "The Early History of Labor Organizations in Texas, 1838-1876," The Southwestern Historical Quarterly, 72 (July 1968): 1-20.

${ }^{54}$ Spratt, Road to Spindletop, pp. 240-242; Allen, Chapters in the History of Organized Labor, pp. 20-21. 
to early May, 1886. Dissension within the union ranks, coupled with poor leadership, became apparent very early in the standoff and the strikers would up losing everything they sought. As the strike collapsed, so did the fortunes of the Knights of Labor. 55

During the late 1880 s and early 1890s, workers

in Texas either expressed their grievances through the Farmer's Alliance and the People's Party or, in the case of the crafts, went into the American Federation of Labor. In 1898, representatives of the crafts unions established the State Federation of Labor and affiliated with the A.F. of L. Since only skilled tradesmen could become members of Federation locals, membership grew rather slowly, especially if compared to the earlier growth rate of the knights. 56

In one of its earliest conventions, the state federation expressed strong denunciation of the "use of convict labor in factories making goods to be sold in competition with products of free labor and the leasing of convict labor for work outside prisons. . . " Federation members wanted state prisoners employed on public works projects around the state or making clothes po. 20-21.

55 Allen, Chapters in History of Organized Labor, ${ }^{56}$ Ibid., pp. 123-124. 
for use within the prison system. The union expressed strong feelings on this issue, which formed a major element of the worker's legislative program. 57

State federation arguments against competing with prisoners derived primarily from economic motivations and, thus, did little to raise the level of debate on the subject. Like their predecessors in the Populist Party, members of the State Federation of Labor contented themselves with simply objecting to the profitable use of prisoners. They offered no suggestions as to how to deal with the dilemma of keeping prisoners busy and selfsustaining yet not in competition with any segment of the free labor force. Perhaps because organized workers of Eered no realistic solutions to the problem, state officials from Governor Campbell on down did little to change the state's orientation toward the contract system until newspaper disclosures forced the issue.

Despite the obvious weakness in their argument, however, the influence of organized workers on the prison problem cannot be discounted. Although industrial laborers made up only 1.6 percent of the state's population in 2900, they were well-organized and committed to importuning legislators in behalf of favorite issues. The Texas

57 Ibid.; Grady Lee Mullenix, "A History of the Texas state Federation of Labor" (Ph.D. dissertation, university of Texas, 1955), pp. 25-30. 
Federation of Labor, unlike its parent organization, the A.F. of L., decided very early to establish legislative committees and maintain regular contact with elected officials. Labor therefore, added its support to the cries of others seeking changes in state prison policies. 58 Another group appears to have been active in the cause of prison reform, although its influence is difficult to measure. The Texas Federation of Women's Clubs, originally founded in 1897 in waco, focused its early efforts on campaigns to establish libraries around the state and to end the killing of rare tropical birds for their plumage. The women also spoke out for the establishment of a state industrial school for girls. 59

Shortly after the establishment of the state organization, it underwent something of an identity crisis. Aithough the women seemed to care deeply about a number of problems in the state, they decided to avoid "even the appearance of meddling in matters political. . . . "Evidently, the women thought it would appear unseemly for them to make an active bid to influence public policy directly. 60

58 Mulienix, "History of State Eederation of Labor," pp. 37-38, 46, 66, 142-143; Allen, Chapters in History of Organized Labor, pp. 132-136.

${ }^{59}$ Stella L. Christian, editor and compiler, The History of the Texas Federation of Women's Clubs (Houston: Dealy-Aden-Elgin Company, Stationers and Printers, 1919), pp. 19-37.

$$
60 \text { Ibid., ?p. 44-45. }
$$


Within a few years, club members chose to cast aside their earlier aversion to politicking. In 1905, they selected Mrs. Cone Johnson of Tyler, wife of a former state senator, to serve as their president. Mrs. Johnson was succeeded by Mrs. J. B. Dibrell, spouse of a former state senator from seguin. Both of these women, committed to seeking change through the political process, drew on their husband's experience and knowledge of the legislative machinery to obtain what they wanted. Under the leadership of these two women, the state federation adopted a more activist posture and endorsed the movement to reform Texas prisons. 61

Prison problems also engaged the attention of the Texas division of the Society for the Friendless, the state branch of a national organization of the same name. The society was a voluntary body supported entirely by private contributions. The state executive board consisted of Anson Rainey, Chie Justice of the Court of Civil Appeals in Dallas; the Reverend Luther Little, Pastor of the First Baptist Church in Galveston; Dr. I. M. Keasby, Head of the School of Political Science at the University of Texas; J. L. Long, Principal of the Dallas Public Schools; Rev. Samuel Marks, a Rabbi from San Antonio; E. G. Douglas, Superintendent of the Gatesville Reformatory; Rev. J. M.

${ }^{61}$ Ibia., op. 40, 140, 197, 225-253. 
Kirwin, Rector of St. Mary's Cathedral in Galveston; and Rev. H. A. Boaz, President of the Fort Worth Polytechnic College. 62

In its attitude toward crime and the treatment of criminals, the society placed itself firmly in the philosophical tradition of the early nineteenth century prison reformers. The best way to reduce crime was to attack its causes, which, according to the society, lay in "the failure of the fundamental institutions (the home, school, church, society, etc.) to keep individuals above the crime line." With this assertion as its basic premise, society members urged the people of Texas to support its programs to keep young people in school, protect against abuse of children, intervene early in the criminal careers of juvenile offenders, provide for evangelical missions in jails and prisons, and assist released prisoners as they made their way back into society. 63

With particular reference to Texas prisons the society in the summer of 1907 pronounced itself generally satisfied. The prison buildings, "with the exception of some unavoidable conditions in convict camps," were sanitary, while prisoners received "wholesome food in

62 First Annual Report of the Society for the Friendiess, Texas Division, $1306-1907$ (Dallas, Texas: Live Oak Printing Company, Printers, 1907), p. 6. ${ }^{63}$ Ibid., pp. 7-14. 
abundance" and were "well-clothed." Furthermore, thanks to the efforts of senior prison officials, "the prisoners' statutory rights are held inviolate regardless of political, financial or personal considerations." To improve the state's penal institutions, the society recommended that the governor extend the privilege of parole to "worthy Negro convicts," that the female prisoners in the outside camps be supervised by a matron, and that "all of those instrumentalities for intellectual and moral improvement" be extended to inmates in the outside camps. It also urged that the insane prisoners be removed to hospitals and that "as fast as practicable" the contract system be abolished. 64

It is difficult to assess the importance of the Society for the Friendless to the prison reform movement in Texas. Society members claimed to have visited almost every location in the state where convicts were kept and yet their descriptions of what they found bore virtually no resemblance to the horrible situation newspaper reporters described a year later. In a sense, therefore, their activities constituted a disservice to the people of Texas, particularly since the organization was headed by such a distinguished body of men.

The combined effort of all the groups that had

64 Ibid., p. 15. 
called for changes in state prison policies since the beginning of the lease period could not force a departure from the idea that prisoners should serve as a source of revenue to the state. The allure of money from the private contractors, coupled with the belief that the arduous work on the farms helped reform the inmates, proved to be virtually impossible to change. Not until a large percentage of the state's citizens became aware of the ghastly conditions in the prison labor camps did the reform Eorces gain the momentum they needed.

Governor Campbell, notwithstanding his stated opposition to placing prisoners on private farms, had done relatively little to accomplish that end. By the time the legislative committee began its work late in his second term, it found that during Campbell's tenure of office, the population in the Rusk facility had been reduced from 831 to 77 inmates. The overwhelming majority of the prisoners had been shipped to farms, both private and state-owned, where living and working conditions were equaliy severe. The depletion of the Rusk population had been brought to Campbell's attention very early in his First term but he did nothing to correct the matter so that near the end of his administration, the East Texas Eacility stood practically deserted. 65

65 John L. Wortham to Thomas $M$. Campbell, January 1, 1907, Campbell Papers, Barker Texas History Center, 
The governor may have believed that, even though prisoner treatment on the state-owned farms was not much better than in private camps, it nevertheless represented an improvement in that the profits of the inmate labor went to the state rather than into private hands. Such fine distinctions, however, meant very little to the prisoners. One inmate wrote that when Campbell came out solidly in favor of penal reform during his first campaign, the prisoners had great hopes for improvement in their lives and encouraged all their "relatives and friends on the outside" to cast their votes for him. Once in office, however, Campbell "put the hardest set of taskmasters over the men known in many years. . . " In addition, the new governor "cane near putting all the men out on leases on the farms." 66

The newspaper exposes of 1908 and 1909

University of Texas at Austin, Austin, Texas; Biennial Report, 1906, p. 27; Biennial Report, 1910, p. 35. Despite Campbeli's poor performance on attacking the problems in the prisons, he had supported several other measures of interest to the reformers. He and his supporters in the Thirty-first Legislature had secured passage of laws limiting the issuance of railroad passes, prohibiting nepotism and had established a state Department of Agriculture. They also had enacted bilis to tighten even more the state regulation of corporations and had made a start at establishing a uniform ad valorem tax rate. Gould, Progressives and Prohibitionists, p. 40 ; Janet Louise Schmelzer, "Thomas Mitchell Campbel1: Progressive Governor of Texas" (M.A. thesis, Texas Christian university, 1975), pp. 25-66.

$$
{ }^{66} \text { wilkinson, Trans-Cedar Lynching, ?. } 100 .
$$


unquestionably formed the primary catalyst that galvanized public opinion and forced the elected leadership of the state to consider ending the contract system. From all appearances, the public outcry that accompanied press disclosures of prison conditions exceeded anyone's expectations. According to one observer, "nothing in twenty years" had so stirred up the citizenry as the investigation of the prison. 67

Newspapers over the state condemned the prison administration and demanded improvement. The Dallas Morning News noted that the public had anticipated some problems in the prison but nothing like what had been uncovered.

Yet, given a political system of irresponsible appointments, where special qualifications count for little and political pull is the all-important consideration. . What could we expect?68

The Sulphur Springs Gazette wrote that even if a certain amount of the inmate testimony were discounted because of exaggeration, there was still much to condemn. "It really looks as iz the State is more intent on making a profit out of its convicts than reforming them."69 similar sentiments

67 "The Texas Penitentiary and Governor Campbell," Earm and Ranch, 28 (December II, 1909): 8 .

68 Dallas Morning News, November 10, 1909, ?. 8. ${ }^{69}$ Ibid., November 9, 1909, ?. 6 . 
came from the editors of the McKinney Democrat-Gazette who contended that,

- - leasing out human beings to private corporations and individuals, and allowing them to be treated worse than dogs, is a burning shame and should no longer be tolerated by a civilized

Even the Rusk Press-Journal, a newspaper one might have expected to take a softer line, heaped criticism on the state officials who permitted the abuses in the outside camps "in order that a few men in Texas may grow rich on the blood of these unfortunate men."

These state convict farms are a disgrace to Christian civilization and the man who pokes his head up in Cherokee County as a candidate for the next Legislature and who is not unequivocally in favor of abolishing them will be gloriously snowed under at the polls. 71

The intensity of the public reaction to the newspaper campaign of 1908-1909 can best be explained by recalling the nature of Texas society at the time. By the end of the first decade of the twentieth century, Texas and its citizens had changed rather substantially since leasing had been adopted. Thanks to the agrarian unrest and political activism of the late nineteenth century, people had come to appreciate the need for government to take a more active role in society. Bourbon

70 Ibid., November 8,1909, p. 6.
71 Ibid., November 2, 1909, p. 6. 
paradigms of limited government providing few services had been cast aside as Texans saw the need to enlist the support of elected officials in resolving some of society's problems .

Improved economic conditions in the state also came into play. The growth and diversification of the economic sector during the late nineteenth century, culminating in the rapid expansion of the oil industry and related areas, had increased state revenues to the point that the income from the lease contracts had become less critical as a source of state government funding. Politically, emotionally, and economically, the citizens of Texas in 1909 were ready to expand the role of government further to provide better care for the wards of the state.

Late in October, 1909, as the legislative investigation of the prison neared its end, many of the state's political leaders gathered in Dallas to attend the state fair and talk shop. After "feeling the public pulse and getting their bearings" for the 1910 elections, the group concluded that the "penitentiary scandal" had aroused more interest and comment among the voters than anything else, even prohibition. Popular feeling ran so strong against the system that, according to a reporter from the San Antonio Daily Express, Governor Campbell had decided to call a special session of the legislature 
following the prison investigation to deal with leases. ${ }^{72}$ The Fourth Called Session of the Thirty-first Legislature met from August 18 until september 10, 1910. Out of this session, and with surprisingly little dissent, came the bill that reorganized the prison system so that all state prisoners were placed under exclusive control of the state. In the course of formulating the new bill, state legislators paid tribute to the importance of the work done by the newspaper reporters, especially George W. Briggs of the San Antonio Express, in bringing to the attention of everyone the terrible conditions in the state's prisons. Indeed, the legislators were so impressed with Briggs' work that they requested he and his press colleagues undertake a similar investigation of "the breeding ground of all crime, the licensed saloon. . . "73 Very near the end of the special session, Governor Campbell addressed the House and Senate assembled to thank them for the work they had done in behalf of all Texas citizens. The governor noted that very early in his administration he had pledged himself "to needed reforms" in the prisons and was pleased that the legislature had

${ }^{72}$ San Artonio Daily Express, October 31, 1909.

73 Journal of the House of Representatives of the Eourth Called Session of the Thirty-Eirst Legislature of Texas (Austin: Von Boeckmann-Jones Company, Printers, 19101, pp. 1, 207-208, 222 . 
accomplished just that. 74 surely some members must have pondered the governor's words carefully and recognized that prison reform, while certainly beneficial and long overdue, had not been a top priority item for either the chief executive or his friends in the legislature. It came as an afterthought of the reform movement, a problem to be corrected only when other more pressing concerns had been dealt with to everyone's satisfaction. That prison problems did not figure prominently in the turn of the century burst of reform simply reinforces the cogent observation made earlier that in everyday affairs most people were too occupied with their own personal lives to give much thought to the welfare of convicted felons. In voting to terminate all forms of leasing in 1910, the state assumed Eull financial responsibility for its convicted lawbreakers. State taxpayers after 1912 began paying all costs incidental to the operation of the prison system. The reasons for such an abrupt change in policy grew out of the process in which the state and its people matured in the decades following the end of the Civil War.

The indebtedness and relative poverty of the early postwar years, coupled with public refusal to spend money for any but basic public programs, resulted in

$$
{ }^{74} \text { Ibid., ?. } 227 .
$$


drastic retrenchment in state spending and reductions in all types of taxes. Such thrift in government led to a low priority designation for all institutions, like prisons, which cared for wards of the state. The public contempt for convicted felons further removed penal facilities from the beneficent ministrations of those few farsighted individuals and groups that sought to extend to the inmates the care and attention to which the law entitled them.

The last quarter of the nineteentn century brought with it pressures to move away from the traditional conservative view of limited government. Economically hard-pressed segments of society, especially farmers, developed a political activism that pressured the dominant Democratic Party into accepting a more expanded role for state government. The agrarian reform movement with its allies, the women's clubs, labor organizations, and the Society for the Friendless, all from the emerging urban middle class, advocated ending the lease system, albeit somewhat lukewarmly, but offered no substitutes acceptable to elected officials.

Deapite all the agitation to improve the treatment of state prisoners, few changes resulted until newspaper disclosures and a major legislative investigation in 1909 revealed for all to see the deplorable conditions in which prisoners lived. Public outrage forced state officials, 
like Governor Campbell, to convene a special session of the legislature in the summer of 1910 to bring an end to leasing and establish a prison policy wherein the state would assume all responsibility for the care of its convicted felons. 


\section{THE TEXAS EXPERIENCE IN PERSPECTIVE}

The history of the Texas prison system for the period 1867 through 1912 may be viewed as the story of the maturation of a large and difficult to manage state agency. The phenomenal growth of the prison population over the forty-five-year period presented prison officials with a variety of problems. The manner in which the difficulties were resolved demonstrates quite clearly that above all else, state leaders consistently sought to exert a greater measure of control over the penal institution so as to make them financially profitable.

Beginning with the first leases of prisoners to the railroads in the late 1860s, prison officers and the supervisory legislative committees encountered abuses and maladministration within prison operations that persisted throughout the late nineteenth and early twentieth centuries. The hiring of an inspector and an assistant inspector to look after the state's interests during the Ward-Dewey and the Cunningham-Ellis leases represented an attempt to secure a more diligent adherence to prison policies. Similarly, the several reorganizations of 
prison management and the promulgation of more extensive and all-encompassing rules and regulations reflected a commitment to make the prisons a dependable source of revenue for the state. There is little credible evidence to support the contention that long-term lease agreements with private parties represented an attempt to reestablish slavery in a somewhat altered form. ${ }^{1}$

In many of its aspects, the Texas experience with convict lease closely resembled penological developments in other parts of the South. All of the eleven states of the former Confederacy adopted some form of leasing during the years immediately following the Civil war. It is always difficult, and frequently misleading, to describe in generalities the attitudes and activities supposedly common to any group of people. Yet to a large degree, the manner in which southern legislatures governed their prisons in the late nineteenth century demonstrated a considerable unanimity of opinion concerning the role of prisons and the objectives of incarceration.

- The same factors--growing criminal population, inadequate facilities, and shortages of money--that led Texas to adopt leasing also came into play in the other southern states. By the early 1870s, the majority of southern prison inmates labored on railroads, in coal

Iparrish, "This Species of Slave Labor," passim. 
and iron mines, and in turpentine camps. Florida and the Carolinas, none of which possessed any permanent penal structures, had to lease their prisoners immediately upon the cessation of hostilities in 1865. Most of the other states adopted leasing in the late $1860 \mathrm{~s}$ and early $1870 \mathrm{~s}$. Alabama and Texas, the two states that had suffered the least wartime damage to their prisons, were the last to turn their penal institutions over to private parties. ${ }^{2}$ Considerable similarity also could be found in the way leasing functioned throughout the South. All of the states ultimately realized a net profit from the prison labor, even if only in the sense that they were spared the expense of maintaining a prison. Although many of the lease contracts made during the late 1860 s and early 1870s did not attain the levels of success the states had envisioned, by the $1880 \mathrm{~s}$ and $1890 \mathrm{~s}$ leasing had proven very profitable and the various state officials welcomed the additional income Erom the prison labor. ${ }^{3}$

The abusive, arbitrary treatment of prisoners, so prevalent in the Texas lease camps, also appeared in the other southern states. From all accounts, prisoners in Florida and the Carolinas, Earticularly those persons

2 Blake McKelvey, "Penal Slavery and Southern Reconstruction," The Journal of Negro History, 22 (Apri1 1935): 153-162. pp. $35-5 \overline{5}$

3rbid.; Carter, "Prison, Politics and Business," 
consigned to the turpentine camps, suffered miseries considerably more severe than other southern prisoners. The absence of any tradition of prison management in the three states likely accounted for the worse than usual conditions. 4

The best informed and most persistent contemporary critic of prison leasing, the Louisiana writer George W. Cable, asserted that Alabama and Texas went to greater lengths to safeguard the interests of their leased prisoners than did the other states of the former Confederacy. In part, the comparatively better conditions derived from a system of state inspection that, despite its frequent failures and shortcomings, considerably exceeded any similar efforts in other parts of the South. Cable also asserted that the two states enjoyed exemplary leadership and guidance from their principal senior administrators during the period. J. H. Bankhead in Alabama and Thomas $\mathrm{J}$. Goree in Texas, both had taken "an active interest in the best developments [in prison reform] in England and in the North," and had attempted to introduce some of the newer ideas into their respective institutions. 5

\section{McKelvey, "Penal Slavery," pp. 158-166. \\ ${ }^{5}$ George $W$. Cable, The Silent South Together with} the Ereedmen's Case in Equity and the Convict Lease System (New York: Charles Scribner's Sons, 1885), pp. 156-157; Mckelvey, "Penal Slavery," pp. 160-162. 
The activities of the few more enlightened and reform minded administrators could not alter substantially the overall picture of neglect and mismanagement that characterized leasing all through the South. The absence of reliable data from southern prisons during the period prohibits a detailed look at either the composition of the prison population, or the fate of the individual inmates. Such scattered evidence that is available, however, strongly suggests that young black southerners with little education made up a disproportionately large segment of the prison populations; that the individual states made few serious efforts to provide adequate food, clothing, medical care, or reformative training for the prisoners; and that the rates of mortality, morbidity, and escape greatly exceeded national norms for the period. ${ }^{6}$

The ability of leasing to endure despite the opposition from critics came about, in part at least, because of the income it generated for the states. A general public indifference to the fate of the prisoners also played a major role. The apparent lack of enthusiasm in nineteenth century Texas for serious prison reforms also appears to have been evident in the other southern states. According to one observer, leasing

6Mckelvey, "Penal Slavery," po. 153-179; Carter, "Prisons, Folitics and Business," pp. 61-85. 
persisted not as a result "of any malicious public intention," but rather because among "the people at large, there is little more than a listless oblivion" toward convicted felons. Once the criminal offenders had been caught, found guilty, and sentenced, the public mind was at rest in the belief that,

- . to punish crime, no matter how, is to deter crime; that when broken laws are avenged that is the end; that it is enough to have the culprit in limbo, if only he is made to suffer and not to cost.?

The influence wielded by the lessees to protect their access to prison workers also came into play to help extend the life of leasing. The efforts of the large sugar growers in Texas to curry favor with the state officials who made prison labor contracts were duplicated by planters, railroads, mining companies, levee construction contractors, and lumbering interests throughout the region. In a few cases, notably Georgia and Alabama, the major lessees also occupied the highest positions of elected leadership in the state. Generally, however, the prison labor contractors, secured their influence with politicians by financial contributions and other support at election time. 8

The movement to end leasing in the southern

${ }^{7}$ Cable, Silent South, op. 124-126.

${ }^{8}$ Carter, "Prisons, Politics and Business," PD. $64-73$. 
states began to appear in the $1890 \mathrm{~s}$ with the emergence of the Populist Party. The continuing distress of the lower economic classes in the South and their entry into politics foreshadowed fundamental changes in the nature of governments. The postwar policies of extreme financial retrenchment and limited state government yielded to demands for enlarged governmental activity as the Bourbon Democrats gave way to a new set of political leaders willing to see an expanded role for government. By the first decade of the twentieth century, the Democratic Party in all of the southern states had announced intentions of ending lease as soon as acceptable substitutes could be found. 9

The end of leasing in the South, which occurred during the years immediately preceding World war I, constituted one of the major progressive reforms in the region. Citizens of the South, motivated by economic and humanitarian concerns and spurred into action by legislative investigations and newspaper disclosures of prison conditions, pressured southern legislatures to terminate the lease contracts and make other provisions for the employment of state prisoners. In general, the southeastern states put their prisoners to work building and maintaining public roads, while the states west of

$$
{ }^{9} \text { Ibid., pp. 91-107. }
$$


Alabama, following the example of the fiarlem plantation in Texas, placed their inmates at work on large farms owned and operated exclusively by the state. 10

The abolition of the lease system in Texas in 1912 represented the culmination of a diverse reform movement that had come together in the early years of the Campbell administration. George W. Briggs, the San Antonio journalist cum social critic who spearheaded the 1909 investigation of the prison, acted within the highest traditions of contemporary investigative reporting. His articles on prison affairs, plus a subsequent expose he wrote of housing conditions among the poor in Texas cities, place him squarely within the group of early twentieth century crusading journalists that played such a prominent part in national progressivism. ${ }^{11}$

The forces Briggs launched with his articles on prison conditions acted from both economic and humanitarian motives. All agreed that the prison labor earned handsome profits, but at a human cost too high to tolerate. As the citizenry moved to end leasing, it did so in a

\section{${ }^{10}$ Ibid.; Blake McKelvey, "A Half Century of} Southern Penal Exploitation," Social Forces, 13 (October 1934): 112-120.

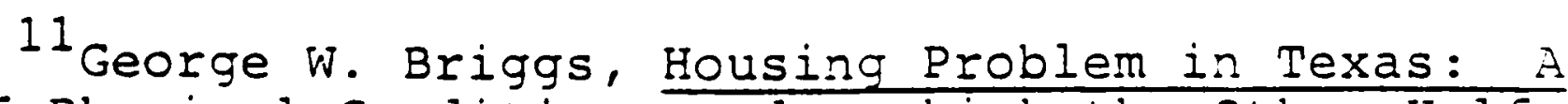
Study of Physical Conditions under which the Other Half Lives, reprint of articles published in the GalvestonDallas News, November through December, 1911, Archives Division, Texas State ibrary, Austin, Texas. 
manner similar to activities in other parts of the nation. The groups leading the opposition to lease in Texas included the numerically-strong agrarian elements and the politically-active, though less numerous, workers. As a reform force, they resembled the dispossessed consumers described by David Thelen as having led progressivism in Wisconsin. According to Thelen, community groups composed of people from a variety of economic backgrounds joined together to attack "corporate arrogance, tax dodging, and unresponsive and undemocratic political machinery. . . " The reformers sought to eliminate privileged economic and political interests so as to bring a sense of justice and accountability into the conduct of political affairs. The Texas groups that opposed lease provided the sheer electoral strength needed to push elected officials to action. 12

As the legislature and the prison board considered alternatives to leasing, other elements of progressivism surfaced. In refashioning the prison administration, state leaders chose to delineate the major managerial areas within the system and to place an experienced individual at the head of each division. Responsibility,

12 David P. Thelen, The New Citizenshio. Origins of Progressivism in Wisconsin, 1885-1900 (Columbia, Missouri: University of Missouri Press, 1972), pp. 55-56, $130-131$. 
thus, would reside with persons competent to handle matters peculiar to the particular area. The emergence of a professional managerial structure corresponds closely to the model of progressivism put forth by Robert Wiebe, who described his progressives as a coming from a new middle class of professional men and women. 13

The Wiebe progressives had witnessed the rapid deterioration of the traditional, personalistic organs of society as the trend toward corporate accumulation and growth accelerated in the late nineteenth century. The reformers sought, among other things, to take the lead in establishing control over state and local agencies that would regulate and direct future growth. The leadership by professionals would insure that as change occurred among the elements of society, it would be stable and directed to serve the best interest of all. 14

The Texas experience with leasing its prisoners constituted a retrogressive step in the development of the state penal system. Indeed, the decision to adopt leasing placed Texas and the South clearly outside the mainstream of national penological advances. Not until the early decades of the twentieth century did the state

13 Robert H. Wiebe, The Search for Order, 18771920 (New York: Hill and wang, 1967), pp. 111-112.

14 Ibid. 
begin to take action to bring its prisons into full conformity with national patterns and standards. Even though the negative effects of leasing were considerable, state officials in the late nineteenth century, nonetheless, found it possible to institute some reforms contemporary with progress in the nation at large.

Superintendent Goree's decision to establish contact with prison officials in other parts of the nation provided a means for infusing into Texas contemporary ideas for prison reform. Through membership in the National Prison Association, the principal organization of professional penologists, Goree and his Texas colleagues were exposed to the latest in penal developments. Attendance at the annual meetings of the national professional organization gave state prison officials an opportunity to learn from the experience of others. Through the latter decades of the nineteenth century, the national association worked assiduously to promote a number of reforms, chiefly the adoption of a classification system for prisoners, the use of the indeterminate sentence, and the construction of special institutions for youthful offenders. The implementation of the indeterminate sentence in Texas in 1883 and the opening of the state juvenile reformatory in 1389 demonstrated that, at least to some degree, Texas found itself able to institute beneficial changes at a time when such 
reforms were still relatively new and much debated throughout the nation. 15 seemingly, Texas prison officials could entertain the prospect of reforms and improvements in the prison as long as such changes posed no threat to the structure of leasing. Not until the termination of all outside contracts in 1912 did Texas begin to assume the degree of responsibility for its convicted felons that had become commonplace in some other sections of the country. 


\section{Primary Sources}

\section{Manuscript Materials}

The following materials are located in the Barker Texas History Center, University of Texas at Austin, Austin, Texas.

Allen, Ruth A., Papers.

Ballinger, William Pitt, Papers.

Brackenridge, Eleanor, Papers.

Burleson, Adele S., Papers.

Burleson, Albert S., Papers.

Burleson, R. C., Papers.

Campbe11, Thomas M., Papers.

Childers, George P., Papers.

Coke, Richard, Scrapbook.

Culberson, Charles D., Papers.

Decherd, Mary, Papers.

Donelson, W. A., Papers.

Edwards, Herbert Rook, Papers.

Heartsill, Fannie, Papers.

Henderson, Thomas S., Papers.

Hogg, James S., Papers.

House, E. M., Papers. 
"Index to Biographical Studies of Texans."

Ireland, John., Papers.

Labor Movement in Texas Collection.

Macune, C. W. "The Farmer's Alliance."

Matlock, Joseph D. Texas Baptist Conference.

Pennybacker, Mrs. Percy V., Papers.

"The Prison Bulletin."

Roberts, Oran M., Papers.

Rockwell, James M. Women's Home Mission Society, Papers.

Rose, A. J., Papers.

Ross, Lawrence S., Papers.

Sayers, Joseph D., Papers.

Sharp, Mrs. Walter B. League of Women Voters and Volunteer Prison League, Papers.

Women's Christian Temperance Union. Scrapbook.

Wooldridge, Alexander P., Papers.

The following materials are located in the Texas State Library, Archives Division, Austin, Texas.

Campbell, Thomas M., Papers.

Coke, Richard, Papers.

Colquitt, Oscar B., Papers.

Davis, Edmund J., Papers.

Hubbard, Richard B., Papers.

"Index to the Papers of the Fifth through the Fourteenth Legislatures."

Ireland, John, Papers.

Office of the Secretary of State. Executive Record Books, 1836-1879. 
Penitentiary Papers.

Prison Reform Association of Texas, Papers.

Records of the Capitol Building Commission.

Roberts, Oran M., Papers.

The following materials are located in the AustinTravis County Collection, Austin Public Library, Austin, Texas.

Brown, Frank. "Annals of Travis County and of the City of Austin from Earliest Times to Close of 1875."

Pease, Elisha M., Papers.

The following materials are located in the Special Collections, Stephen F. Austin State University Library, Nacogdoches, Texas.

Angelina and Neches River Railroad Company, Papers.

Angelina County Lumber Company, Papers.

Kirby Lumber Company, Papers.

Kurth, E. L., Papers.

The following materials are located in the Texas Collection, Baylor University, Waco, Texas.

Ross, Lawrence S., Papers.

Russell, Bud. "Reminiscences."

The following material is located in the Sam Houston Regional Research Center, Liberty, Texas.

Prison Reform Collection, Papers.

The following material is located in the Fort Bend County Historicai Museum, Rosenberg, Texas.

"Sugarland and the Men who Made It."

The following material is located in the special Collections, University of Arkansas Library, Fayetteville, Arkansas.

Ferguson, John L., State Historian. "A History of the Arkansas Penitentiary." 
Official Documents and Reports

Address of T. J. Goree, Superintendent of Penitentiaries, on the Penitentiary Leases, delivered before the Penitentiary Committees of the Senate and House of Representatives, Eighteenth Legislature in Joint Session, February 14, 1883. Austin: E. W. Swindells, State Printer, 1883.

Annual Report of the Officials of the Texas Prison System for the Year Ending December 31, 1911. Austin: Von Boeckmann-Jones Co., Printers, 1912.

Biennial Report of the Commissioners, Superintendent, Financial Agent and Subordinate officers of the Texas State Penitentiaries for the Fiscal Years Ending August 31, 1907, and August 31, 1908. Austin: Von Boeckmann-Jones, Co., Printers, 1908.

Biennial Report of the Commissioners, Superintendent, Financial Agent and Subordinate officers of the Texas State Penitentiaries for the Fiscal Years Ending August 31, A.D. 1906. Austin: Von Boeckmann-Jones Co., Printers, 1906.

Biennial Report of the Commissioners, Superintendent, and Financial Agent of [the] Texas State Penitentiaries for Fiscal Years Ending August 31, 1902. Austin: Von Boeckmann, Schutze \& Co., State Printers, 1902.

Biennial Report of the Commissioners and Superintendent of the Texas State Penitentiary at Huntsville, Walker County, Texas, December 1, 1878. Galveston, Texas: Book and Job Oficice of the Galveston News, 1878.

Biennial Reports of the Directors and Superintendent of the Texas state Penitentiary at Huntsville, Texas with the Report of the Prison Physician, commencing December 1, A.D. 1878, and terminating October 31, A.D. 1880. Galveston: The News Book and Job Office, 1881 .

Biennial Reoorts of the Penitentiary Board and Superintendent of the Texas State Penitentiary at Huntsville, Texas with Reports of Physician and Chaplain. November 1,1880 to October 31,1882 . Austin: E. W. Swindells, State Printers, 1882 .

Biennial Report of the Superintendent of [the] Texas state Penitentiaries for Twenty-four Months Ending August 31, 1904. Austin: State Printing Company, 1905. 
Biennial Report of Superintendent of Texas State Penitentiaries for Twenty-four Months Ending August 31, 1910. N.p.: n.p., n.d.

Biennial Report of the Superintendent of Texas state Penitentiaries for Two Years Ending October 31, 1900 . Austin: Von Boeckmann, Moore-Schutze, State Printers, 1900.

Bond of Lessee of Texas State Penitentiary, Under Lease made January $1,1878$.

Department of Commerce. Bureau of the Census. Thirteenth Census of the United States taken in the Year 1910, vol. 3, Population. Washington, D.C.: Government Printing Office, 1913.

Department of the Interior. The Statistics of the Population of the United States, Embracing the Tables of Race, Nationality, Sex, Selected Ages, and Occupation. Ninth Census, vol. 1. Washington, D.C.: Government Printing Office, 1872.

Financial Report Texas State Penitentiary System from April 1, 1910 to January 20, 1911. Austin: Austin Printing Company, 1911.

First Biennial Report of the Bureau of Labor Statistics of the State of Texas, 1909-1910. Austin: Von Boeckmann-Jones Co., Printers, 1910.

General Laws of the State of Texas Passed at the Regular Session of the Twenty-eighth Legislature Convened at the City of Austin, January 13, 1903, and Adjourned April 1, 1903. Austin: Von BoeckmannJones Company, State Printers, 1903.

Governor's Messages, Coke to Ross, 1874-1891. Edited by and for the Archive and History Department of the Texas State Library. Austin: A. C. Baldwin and Sons, 1916.

Journal of the Constitutional Convention of the state of Texas, 1875. N.P., n.d.

Journal of the Reconstruction Convention, which met at Austin, Texas, June 1, A.D. 1868. Austin: Tracy Siemering and Company, Printers, 1870.

Journals of the House of Representatives and the Senate for the Eleventh through the Thirty-first Legislatures, 1866 through 1910. 
Members of the Legislature of the State of Texas from 1846 to 1939 . N.P., n.d., 1939.

Message of Governor Edmund J. Davis of the State of Texas. Austin: J. G. Tracy, State Printer, 1871.

Message of Governor T. M. Campbell to the First Called Session of the Thirtieth Legislature of Texas. Austin: N.P., 1907.

Message of Governor T. M. Campbell to the Thirtieth Legislature of Texas. Austin: N.P., 1907.

Message of Governor T. M. Campbell to the Thirty-first Legislature of Texas. Austin: Von BoeckmannJones Co., Printers, 1909.

Message of Governor T. M. Campbell to the Thirty-second Legislature of Texas. Austin: Austin Printing Company, 1910 .

The Penal Code of the State of Texas. Adopted at the Regular Session of the Twenty-fourth Legislature, 1895. Austin: Eugene Von Boeckmann, 1895.

The Penal Code of the State of Texas Passed by the Sixteenth Legislature, February 21, 1879, took effect July 24, 1879. Austin: State Printing Office, 1887 .

The Penitentiary Leases, Speeches delivered in the House favoring their Ratification by Hon. J. Q. Chenoweth, Hon. H. J. Labatt, Hon. R. R. Hazlewood, Hon. A. K. Swan, Hon. W. F. Upton, and Hon. A. J. Chambers, March, 1883. Pustin: Press of Defenbaugh and Company, 1883 .

The President's Comission on Law Enforcement and Administration of Justice. The Challenge of Crime in a Free Society. Washington: Government Printing Office, 1967 .

A Record of Evidence and Statements Before the Penitentiary Investigating Committee Appointed by the Thirty-third Legislature of Texas. Austin: A. C. Baldwin and Sons, 1913.

Report of the Board of Directors of the Texas State Penitentiary to the Governor, March, 1876. Houston:

A. C. Gray, State Printer, 1876. 
Report of the Commission Appointed by the Governor of Texas, April 10, 1875, to Investigate the Alleged Mismanagement and Cruel Treatment of the Convicts. Houston: A. C. Gray, State Printer, 1875 .

Report of the Committee of the Senate and the Central Executive Committee of the House of Representatives Composing a Legislative Committee to Investigate the Departments of the state Government and the State Institutions; Under Simple Resolutions of the Senate and House. Third Called Session of the Thirty-fifth Legislature of the State of Texas. N.P., 1918 .

Report of the Condition of the Texas State Penitentiary for the Years 1874, 1875, 1876. Houston: A. C. Gray, State Printer, 1876 .

Report on the Condition of the State Penitentiary. Huntsville, February 10, 1870. Austin: Tracy, Siemering \& Co., Printers, State Journal Office, 1870. (Report prepared and submitted by N. A. M. Dudley, Brevet Colonel, U.S.A. and Superintendent.)

Reports on the Condition of the Texas State Penitentiary, for the Years 1871-2. Austin: James P. Newcomb and Company, 1873 .

Reports on the Condition of the Texas State Penitentiary for the Years 1873-4. Houston: A. C. Gray, State Printer, 1874.

Report 0 the Inspector of the Texas State Penitentiary, located at Huntsville, Texas, to the Governor of Texas. Submitted October 16, 1876. H. K. White, Inspector. Galveston: Shaw \& Blaylock, State Printers, 1876 .

Report of the Lessees of the Texas State Penitentiary, April, 1876. Houston: Telegraph Steam Book and Job Print, 1876.

Report of the Penitentiary Investigating Committee Including all Exhibits and Textimony Taken bv the Committee. N.P., 19.10 .

Report and Proceedings of the State Investigating Committee. Provided for in Senate Joint Resolution No. I, Passed at the Second Called Session, Twenty-seventh Legislature. Austin: Von Boeckmann, Schutze and Co., State Printers, 1902. 
Report of the Senate Committee Investigating the Affairs of the Prison System of Texas Under Simple Resolutions Nos. 39 and 41 of the Senate. First Called Session of the Thirty-fourth Legislature. Austin: A. C. Baldwin and Sons, State Printer, 1915 .

Report of Special Committee on Penitentiary, State of Texas. Austin: J. G. Tracy, State Printer, 1871.

Report of the Superintendent of the State Penitentiary. Austin: J. G. Tracy, State Printer, 1871.

Reports of the Superintendent and Financial Agent of the Texas State Penitentiaries. Embodying the Proceedings of the Penitentiary Board, and Statistical and Financial Exhibits; Also Reports of Subordinate Officers of the Texas State Penitentiaries for Two Years, Ending October 31, 1888. Austin: Eugene Von Boeckmann, State Printer, 1889.

Reports of the Superintendent and Financial Agent of the Texas State Penitentiaries. Embodying the Proceedings of the Penitentiary Board, and Statistical and Financial Exhibits; Also Reports of Subordinate Officers of the Texas State Penitentiaries, for Two Years, Ending October 31, 1886. Austin, Texas: Triplett \& Hutchings, State Printers, 1886.

Reports of the Superintendent and Financial Agent of the Texas State Penitentiaries Embodying the Proceedings of the Penitentiary Board, and Statistical and Financial Exhibits; Also Reports of Subordinate Officers of the Texas State Penitentiaries, for Two Years Ending October 31, 1890. Austin, Texas: Henry Hutchings, State Printer, 1890.

Reports of the Superintendent and Financial Agent of the Texas State Penitentiaries, Embodying the Proceedings of the Penitentiary Board, and Statistical and Financial Exhibits, Also Reports of Subordinate Officers of the Texas state Penitentiaries, for Two Years Ending October 31, 1894. Austin: Ben C. Jones and Company, State Printers, 1894.

Reports of the Superintendent and Financial Agent of the Texas State Penitentiaries, Embodying the Proceedings of the Penitentiary Board, and Statistical and Financial Exhibits; Also Reports of Subordinate Officers of the Texas state Penitentiaries, for Two Years Ending October 31, 1892. Austin: Ben C. Jones and Company, State Printers, 1892. 
Reports of the Superintendent and Financial Agent of the Texas State Penitentiaries, Embodying the Proceedings of the State Penitentiary Board, and Statistical and Financial Exhibits; Also Reports of Subordinate officers of the Texas State Penitentiaries, for Two Years Ending October 31, 1884 . Austin: E. W. Swindells, State Printer, 1885 .

Reports of the Superintendent and Financial Agent of the Texas State Penitentiaries, Embodying Statistical and Financial Exhibits; Also Reports of Subordinate Officers of the Texas State Penitentiaries. Austin: Von Boeckmann, Moore and Schutze, State Contractors, 1898.

Reports of the Superintendent and Financial Agent of the Texas State Penitentiaries, Embodying Statistical and Financial Exhibits; Also Reports of Subordinate Officers of the Texas State Penitentiaries For Two Years Ending October 31, 1896. Austin: Ben C. Jones and Company, State Printers, 1896.

Rules and By-Laws Adopted by the Board of Public Labor, Relative to Employment of Convicts on Works of Public Utility. Austin: Jo. Walker, State Printer, at Gazette Office, 1867.

Rules and By-Laws for the Government of the Texas State Penitentiary. Revised and amended. Galveston: Shaw and Blaylock, State Printer, 1877.

Rules, Regulations, and By-Laws for the Government and Discipline of the Texas State Penitentiaries and the Convicts Belonging Thereto at Huntsville and Rusk and at Outside Camps. Austin: Ben C. Jones and Company, State Printers, 1893.

Rules, Regulations, and BV-Laws for the Government and Discipline of the Texas State Penitentiaries and the Convicts Belonging Thereto at Huntsville and Rusk and at Outside Camps. Austin: State Printing Office, 1888 .

Rules, Regulations, and By-Laws for the Government and Discipline of the Texas state Penitentiaries, at Huntsville and Rusk, Texas. Austin: E. W. Swindells, State Printer, 1883. 
Rules and By-Laws for the Government of the Texas State Penitentiary. Adopted by the Board of Directors, July 16, 1875, and Approved by the Governor, July 22, 1875. Houston: A. C. Gray, State Printer, 1875 .

Second Annual Report of the Commissioner of Labor, 1886 . Convict Labor. Washington: Government Printing Office, 1887 .

Speech of Thomas M. Campbell Opening his Campaign for Governor of Texas, at Athens, Texas, April 21, 1906. Palestine, Texas: Palestine Printing Company, 1906.

Twentieth Annual Report of the Commissioner of Labor, 1905. Convict Labor. Washington: Government Printing Office, 1906 .

Books

An Open Letter to the Legislators of the State of Texas, from 0 . A. McGinnis of Michigan. N.p., 1879.

Briggs, George Waverly. The Housing Problem in Texas. A Study of Physical Conditions Under which the Other Half Lives. Galveston-Dallas News, 1911.

- The Texas Penitentiary, History of the Texas Convict System and Suggestions for Its Betterment. San Antonio Express, n.d.

Campbell, Charles C. Hell Exploded. An Exposition of Barbarous Cruelty and Prison Horrors. N.p., 1900 .

Finty, Tom, Jr., et al. Our Penal System and Its Purposes. Galveston-Dallas News, 1909.

First Annual Report of the Society for the Friendless, Texas Division, 1906-1907. Dallas: Live Oak Printing Company, Printers, 1907.

Gammel, H. P. N., comp. The Laws of Texas, 1822-1897. 10 vols. Austin: The Gammel Book Company, 1898.

George, A. L. The Texas convict. Thrilling and Terrible Experience of a Texas Boy. Austin: Ben C. Jones and Company, Printers, 1893.

Nosser, William. It's Hell in a Texas Pen. N.p., n.d. 
Paschal, George W. A Digest of the Laws of Texas: Containing Laws in Force, and the Repealed Laws on which Rights Rest. Washington, D.C.: W. H. and O. H. Morrison, 1873 .

Proceedings of the Annual Congress of the National Prison Association of the United States, held at Austin, Texas, December 2-6, 1897. Pittsburgh: Shaw Brothers Printers, 1898.

Proceedings of the Annual Congress of the National Prison Association of the United States, held at Baltimore, December 3-7, 1892. Pittsburgh: Shaw Brothers, Printers, 1893.

Proceedings of the Annual Congress of the National Prison Association of the United States, held at Boston, July 14-19, 1888. Chicago: Knight and Leonard Company, Printers, 1888 .

Proceedings of the Annual Congress of the National Prison Association of the United States, held at Chicago, June 7-10, 1893. Chicago: Knight and Leonard Company, Printers, 1893.

Proceedings of the Annual Congress of the National Prison Association of the United States, held at Cincinnati, September 25-30, 1890. Pittsburgh: Shaw Brothers, Printers, 1891 .

Proceedings of the Annual Congress of the National Prison Association of the United States, held at Denver, Colorado, September 14-18, 1895. Pittsburgh: Shaw Brothers, Printers, 1896.

Proceedings of the Annual Congress of the National Prison Association of the United States, held at Milwaukee, Wisconsin, September 26-30, 1896. Pittsburgh: Shaw Brothers, Printers, 1897.

Proceedings of the Annual Congress of the National Prison Association of the United States, held at Nashville, November $16-20,1889$. Chicago: Knight and Leonard Company, Printers, 1890.

Proceedings of the Annual Congress of the National Prison Association of the United States, held at Pittsburg, October 10-14, 1891. Pittsburgh: Shaw Brothers, Printers, 1892 . 
Proceedings of the Annual Congress of the National Prison Association of the United States, held at St. Paul, Minnesota, June 16-20, 1894. Pittsburgh: Shaw Brothers, Printers, 1894 .

Proceedings of the Annual Congress of the National Prison Association of the United States, held at Toronto, September 10-15, 1887. Chicago: Knight and Leonard Company, Printers, 1889.

Proceedings of the Taxpayer's Convention of the State of Texas, held at the City of Austin, September 22nd, $23 \mathrm{rd}$, and 25th, 1871. Also a Memorial to the Legislature and an Address to the Taxpayers of Texas. Galveston: News Steam Book and Job Office, 1871 .

Shotwell, John. A Victim of Revenge or Fourteen Years in Hell. San Antonio, Texas: E. T. Jackson Company, $\overline{1909}$.

Tomlin, Henry. Henry Tomlin. The Man Who Fought the Brutality and Oppression of the Ring in the State of Texas for Eighteen Years, and Won. N.P., 1906.

Wilkinson, J. L. The Trans-Cedar Lynching and the Texas Penitentiary. Dallas: Johnston Printing and Advertising Company, n.d.

Winkler, Ernest William, ed. Platforms of Political Parties in Texas. Bulletin of the University of Texas, No. 53, 1916.

\section{Newspapers}

Austin Statesman. 1871, 1873, 1874, 1878, 1879, 1883, $1884,1906,1912$.

Clarksville Northern Standard. 1850, 1853, 1856, 1857, 1858 . (Jallas $\frac{\text { Herald. } 1870,1871,1872,1873,1874,1875,1876,}{1877,1878,1881,1882,1883,1884,1885 .}$

Dalias Morning News. 1898, 1902, 1909.

Galveston Daily News. 1867, 1871, 1873, 1875, 1876, 1877, $1882,1883,1885,1886,1898$.

Houston Daily Post. 1883, 1904. 
Houston Daily Telegraph. 1871.

Rosenberg Herald Coaster. 1972.

San Antonio Express. 1871, 1881, 1909, 1912.

Texas Siftings. 1883.

Texas State Gazette. 1853.

Wood County Flag. 1879.

\section{Secondary Sources}

\section{Official Documents and Reports}

Meyer, Hermann H. B., Compiler. United States Library of Congress List of References on Prison Labor. Washington: Government Printing Office, 1915.

Sixty-third Congress. Second Session. Federal and State Laws Relating to Convict Labor. Senate Documents, Volume 17. Washington: Government Printing office, 1914 .

Books

Allen, Harry E., and Simonsen, Clifford E. Corrections in America: An Introduction. 2nd ed. Encino, California: Glencoe Publishing Co., Inc., 1978.

Allen, Ruth. Chapters in the History of Organized Labor in Texas. University of Texas Publication, No. 4143,1941 .

Allhands, J. L. Boll Weevil. Recollections of the Trinity and Brazos Valley Railway. Houston: The Anson Jones Press, 1946.

Aptheker, Herbert, ed. A Documentary History of the Negro People in the united States. New York: The Citadel Press, 1951 .

Barnes, Harry Elmer, and Teeters, Negley. New Horizons in Criminology. 3rd ed. Englewood Cliffs, New Jersey: Prentice-Hall, Inc., 1943. 
Barnes, Harry Elmer. The Story of Punishment. A Record of Man's Inhumanity to Man. 2nd ed. Montclair, New Jersey: Patterson Smith, 1972. [The Stratford Company, 1930.]

Barr, Alwyn. Black Texans. A History of Negroes in Texas, 1528-1971. Austin: Jenkins Publishing Company, 1973.

- Reconstruction to Reform. Texas Politics, 18761906. Austin: University of Texas Press, 1971.

de Beaumont, Gustave, and de Tocqueville, Alexis. On the Penitentiary System in the United States and Its Application in France. Carbondale, Illinois: Southern Illinois University Press, 1964. [1833.]

Beckford, George. Persistent Poverty. Underdevelopment in Plantation Economies of the Third World. New York: Oxford University Press, 1972.

Biographical Encyclopedia of Texas. New York: Southern Publishing Company, 1880 .

Biographical Souvenir of the State of Texas, Containing Biographical Sketches of the Representative Public and Many Early Settled Families. Chicago: F. A. Battey and Company, 1889.

Blom-Cooper, Louis, ed. Progress in Penal Reform. London: Clarendon Press, 1974.

Brewer, J. Mason. Negro Legislators of Texas and Their Descendants. Austin: Jenkins Publishing Company, 1970 .

Brown, John Henry. Indian wars and Pioneers of Texas. Austin: I. E. Daniell, Publisher, n.d.

Buenker, John D. Urban Liberalism and Progressive Reform. New York: W. W. Norton and Company, Inc., 1978. [Charles Scribner's Sons, 1973.]

Cable, George W. The Silent South Together with the Freedman's Case in Equity and the Convict Lease System. New York: Charles Scribner's Sons, 1885.

Carleton, Mark T. Politics and Punishment. The History of the Louisiana State Penal System. Baton Rouge: Louisiana State University Press, 1971. 
Carlson, Avery Luvere. A Monetary and Banking History of Texas from the Mexican Regime to the Present Day, 1821-1929. Fort Worth, Texas: The Fort Worth National Bank, 1930 .

Carroll, J. M. The History of Texas Baptists. Dallas: Baptist Standard Publishing Company, 1923.

- Texas Baptist Statistics, 1895. Houston: J. J. Pastoriza Printing and Lithographing Co., n.d.

Cartwright, William H., and Watson, Richard L. Jr. The Reinterpretation of American History and Culture. Washington, D.C.: National Council for the Social Studies, 1973.

Casdorph, Paul. A History of the Republican Party in Texas, 1865-1965. Austin: The Pemberton Press, 1965 .

Christian, Stella L., ed. and comp. The History of the Texas Federation of Women's Clubs. Houston: Dealy-Aden-Elgin Company, Stationers and Printers, 1919.

Cotner, Robert C., ed. Addresses and State Papers of James Stephen Hogg. Austin: University of Texas Press, 1951.

- James Stephen Hogg: A Biography. Austin: University of Texas Press, 1959.

Daniel, Pete. The Shadow of Slavery: Peonage in the South, 1901-1969. Urbana, Chicago and London: University of Illinois Press, 1972.

Daniell, L. E. Personnel of the Texas State Government, with Sketches of Distinguished Texans, Embracing the Executive and Staff, Heads of the Departments, United States Senators and Representatives, Member of the Twenty-first Legislature. Austin: Smith, Hicks, and Jones, State Printers, 1889.

- Personnel of the Texas State Government with Sketches of Representative Men of Texas. San Antonio: Maverick Printing House, 1892.

- Texas the Country and Its Men. N.p., n.d.

- Types of Successful Men of Texas. Austin: Eugene von Boeckmann, Printer and Bookbinder, 1890 . 
Dawson, Joseph Martin. A Century with Texas Baptists. Nashville: The Broadman Press, 1947.

Deason, Beecher. Seven Years in Texas Prisons. N.p., n.d.

Federal Writers Project of Texas. St. David's Through the Years. Austin: St. David's Guild, 1942.

Foucalt, Michel. Discipline and Punish. The Birth of the Prison. Translated from the French by Alan Sheridan. New York: Pantheon Books, 1977. [Paris: Editions Gallimard, 1975.]

Gossett, Thomas F. Race. The History of an Idea in America. Dallas: Southern Methodist University Press, 1963.

Gould, Lewis I. Progressives and Prohibitionists. Texas Democrats in the Wilson Era. Austin: University of Texas Press, 1973 .

Grant, H. Roger. Insurance Reform. Consumer Action in the Progressive Era. Ames, Iowa: The Iowa State University Press, 1979.

Gray, Francis C.. Prison Discipline in America. Montclair, New Jersey: Patterson Smith, 1973. [Boston:

Charles C. Little and James Brown, 1847.]

Green, James R. Grass-Roots Socialism. Radical Movements in the Southwest, 1895-1943. Baton Rouge: Louisiana State University Press, 1978.

Hardy, Dermot H., and Roberts, Ingham S., eds. Historical Review of South-East Texas. 2 vols. Chicago: The Lewis Publishing Company, 1910.

Held, John A. Religion: A Factor in Building Texas. San Antonio: The Naylor Company, 1940.

Hill, L. B., ed. A History of Greater Dallas and Vicinity. 2 vols. Chicago: The Lewis Publishing Company, 1909.

Hindus, Michael Stephen. Prison and Plantation. Crime, Justice, and Authority in Massachusetts and South Carolina, 1767-1878. Chapel Hill, North Carolina: The University of North Carolina Press, 1980.

Fohes, Pauline Buck. County Texas. San Antonio: The Naylor Company, 1936 . 
Hunt, Robert Lee. A History of Farmer Movements in the Southwest, 1873-1925. College Station: Texas A\&M Press, 1935 .

Johnson, Frank w. A History of Texas and Texans. 5 vols. Edited by $E$. C. Barker, with assistance of E. W. winkler. Chicago and New York: American Historical Society, 1914.

Johnson, Sid S. Texans who Wore the Gray. N.p., n.d.

Johnson, William R. A Short History of the Sugar Industry in Texas. Texas Gulf Coast Historical Association, 1961 .

Kittrel1, Norman G. Governors who Have Been, and Other Public Men of Texas. Houston: Dealy-Aden-Elgin Company, 1921 .

Krantz, Sheldon. Cases and Vaterials on the Law of Corrections and Prisoner's Rights. St. Paul, Minnesota: West Publishing Company, 1973.

Lang, Aldon Socrates. Financial History of the Public Lands in Texas. The Baylor University Bulletin 35, July 1932.

Lewis, Orlando E. The Develooment of American Prisons and Prison Customs, 1776-1845. Montclair, New Jersey: Patterson Smith, 1967. [1922.]

Loughery, E. $\because$. Personne 1 of the Texas State Government for 1885. Austin: L. E. Daniell, publisher. J. M. Snyder Book and Job Printer, 1885 .

Lynch, James D. The Bench and Bar of Texas. St. Louis: Nixon-Jones Printing Company, 1885 .

McKay, Seth Shepard. Seven Decades of the Texas Constitution of 1876 . N.?., n.d.

McKay, Seth Shepard, and Eaulk, Odie B. Texas After Soindietop. Austin: Steck-Vaughn Company, 1965.

McKelrey, 3lake. American Prisons. A Study in American Social History Prior to 1915. Chicago: The University of Chicago Press, 1936.

McKitrick, Reuben. The Public Land System of Texas, 18231910. Builetin of the University of Wisconsin No. 905,1918 . 
McLaurin, Melton Alonzo. The Knights of Labor in the South. Westport, Connecticut: Greenwood Press, 1978 .

McMath, Robert C., Jr. Populist Vanguard. A History of the Southern Farmer's Alliance. New York: W. W. Norton and Company, Inc., 1977. [University of North Carolina Press, 1975.]

Mannheim, Herman, ed. Pioneers in Criminology. London: Stevens and Sons, Limited, 1960 .

Martin, Roscoe. The People's Party in Texas. A Study in Third-Party Politics. Austin: University of Texas Press, 1970. [University of Texas Bulletin No. 3308, 1933.]

Miller, Edmund T. A Financial History of Texas. Bulletin of the University of Texas No. 37, 1916.

Moneyhon, Carl H. Republicanism in Reconstruction Texas. Austin: University of Texas Press, 1980.

Novak, Daniel A. The wheel of Servitude. Black Forced Labor After Slavery. Lexington, Kentucky: The University Press of Kentucky, 1978.

Overbeck, Ruth Ann. Alexander Penn Wooldridge. Austin: Von Beckman-Jones, 1963.

Painter, Nell Irwin. Exodusters. Black Migration to Kansas after Reconstruction. New York: Alfred A. Knopf, 1977 .

Potts, Charles Shirley. Crime and the Treatment of the Criminal. Bulletin of the University of Texas No. 146, May 1910 .

Rabinowitz, Howard N. Southern Black Leaders of the Reconstruction Era. Urbana, Illinois: University of Illinois Press, 1982.

Ramsdeli, Charles william. Reconstruction in Texas. Austin: University of Texas Press, 1970. [1910.]

Reed, S. G. A History of Texas Railroads and of Transportation Conditions Under Soain and Mexico and the Republic and the State. Houston: The St. Clair Publishing Compan $;, 1941$. 
Rice, Lawrence D. The Negro in Texas, 1874-1900. Baton Rouge: Louisiana State University Press, 1971.

Richardson, Rupert N. Colonel Edward M. House: The Texas Years, 1858-1912. Abilene, Texas: Abilene Printing and Stationery Company, 1964.

Riley, B. F. History of the Baptists of Texas. Dallas: N.P., 1907 .

Roach, Hattie Joplin. The Hills of Cherokee. Fort Worth, Texas: News Printing Company, Inc., 1952.

Rothman, David J. The Discovery of the Asylum. Social Order and Disorder in the New Republic. Boston: Little, Brown and Company, 1971.

Rusche, Georg, and Kirchheimer, Otto. Punishment and Social Structure. New York: Columbia University Press, 1939.

Sellin, J. Thorsten. Slavery and the Penal System. New York: Elsevier, 1976.

Seymour, Charles. The Intimate Papers of Colonel House. Boston: Houghton MiEflin Company, 1926.

Sitterson, J. Carlyle. Sugar Country: The Cane Sugar Industry in the South, 1753-1950. Lexington, Kentucky: The University of Kentucky Press, 1953.

Sowell, A. J. History of Fort Bend County. Houston: W. H. Coyle and Company, Stationers and Printers, 1904 .

Spratt, John Stricklin. The Road to Spindletop. Economic Change in Texas, 1875-1901. Austin: University of Texas Press, 1970. [Southern Methodist University Press, 1955.]

Steen, Ralph W. Twentieth Century Texas. Austin: The Steck Company, 1942 .

Strobel, Abner J. The Old Plantations and Their Owners of Brazoria County, Texas. Houston: Union National Bank, 1926.

Thelen, David ?. The New Citizenship. Origins of Progressivism in Wisconsin, 1885-1900. Columbia, Missouri: University of Missouri Press, 1972. 
Walker, Samuel. Popular Justice. A History of American Criminal Justice. New York: Oxford University Press, 1980 .

Wallace, Ernest. Texas in Turmoil. Austin: SteckVaughn Company, 1965.

Warner, H. T.; Fitzgerald, Hugh N.; Gooch, T. C.; Bonner, T. S.; Mapes, J. L., and Travis, Edmunds, eds. Texans and Their State. Houston: The Texas Biographical Association, n.d.

Webb, Walter Prescott. The Handbook of Texas. Vols. I and 2. Austin: The Texas State Historical Association, 1952.

Weinstein, James. The Corporate Ideal in the Liberal State, 1900-1918. Boston: Beacon Press, 1968.

Wharton, Clarence R. History of Fort Bend County. San Antonio: The Naylor Company, 1939.

White, E. V., and Leonard, Wm. E. Studies in Farm Tenancy in Texas. Bulletin of the University of Texas No. $21,1915$.

iniebe, Robert $H$. The Search for Order, 1877-1920. New York: Hill and Wang, 196\%.

ivines, Enoch C., and Dwight, Theodore w. Report on the Prisons and Reformatories o E the United States and Canada. New York: AMS Press, Inc., 1973. [1867.]

Wines, Frederick Howard. Punishment and Reformation. An Historical Sketch of the Rise of the Penitentiary System. Niew York: Benjamin Blom, Inc., 1971. $[1895$.

Nisrer, Elizabeth. Public Welfare Administration in Louisiana. New York: Arno Press, 1976. [Chicago: The University of Chicago Press, 1930.]

Noodward, C. Vann. American Counterpoint. Slavery and Racism in the North-South Dialogue. Boston: Iittle, Brown and Company, 1964.

Yeary, Mamie, comp. Reminiscences of the Bovs in Gray, 186-1865. Dallas: Smith and Lamar ?ublising House, 1912 . 
Yelderman, Pauline. The Jay Bird Democratic Association of Fort Bend County. A White Man's Union. Waco,

Ziegler, Jesse A. Wave of the Gulf. San Antonio: The Naylor Company, 1938 .

Articles and Scholarly Presentations

Allen, Ruth A. "The Capitol Boycott: A Study in Peaceful Labor Tactics." Southwestern Historical Quarterly 42 (April 1939): $316-326$.

"Atrocities Developed by the Penitentiary Committee." Farm and Ranch 28 (July 31, 1909): 8 .

Baenziger, Ann Patton. "The Texas State Police During Reconstruction: A Reexamination." Southwestern Historical Quarterly 72 (April 1969): 470-491.

Baughman, James P., ed. "Letters from the Texas coast, 1875." Southwestern Historical Quarterly 69 (April 1966): 499-575.

Bayliss, Garland E. "The Arkansas State Penitentiary Under Democratic Control." Arkansas Historical Quarterly 34 (Autumn 1975): 195-213.

Carleton, Mark T. "The Politics of the Convict Lease System in Louisiana, 1868-1901." Louisiana History 8 (Winter 1967): 5-25.

Cohen, William. "Negro Involuntary Servitude in the South, 1865-1940. A Preliminary Analysis." The Journal of Southern History 42 (February 1976): $31-60$.

Crouch, Barry A., and Schultz, L. J. "Crisis in Color: Racial Separation in Texas During Reconstruction." Civil War History 16 (March 1970): 37-49.

Devlin, Robert T. "Prison Labor." Overland Monthly 7 (May 1886) : 504-508.

Doherty, Herbert J., Jr. "Voices of Protest from the New South, 1875-1910." Mississippi Valley Historical Review 42 (June 1955): $\$ 5-66$.

"Donaghey, The Lease System and the Press." The Survey 29 (January 4, 1913) : 410-411. 
DuBois, W. E. Burghardt. "The Spawn of Slavery: The Convict Lease System in the South." The Missionary Review of the World (October 1901): 737-765.

Dugas, Vera Lea. "Texas Industry, 1860-1880." Southwestern Historical Quarterly 59 (October 1955): $151-183$.

Duncan, J. S. "Richard Bennett Hubbard and State Resumption of the Penitentiary, 1876-1878." Texana 3 $(1974): 47-55$.

Duncan, Otis D. "An Analysis of the Population of the Texas Penitentiary from 1906 to $1924 . "$ American Journal of Sociology 36 (March 1981): 770-781.

Finty, Tom, Jr. "The Texas Prison Investigation." Survey 22 (December 18, 1909): 387-391.

- "Troubles of the Texas Prison System." The Delinquent 4 (January 1914): 5-10.

- Troubles of the Texas State Prisons." The Delinguent 3 (December 1913): 1-5.

Hiller, E. T. "Development of the Systems of Control of Convict Labor in the United States." Journal of Criminal Law, Criminology, and Police Science 5 $(1914-1915): 247-264$.

- "Labor Unionism and Convict Labor." Journal of Criminal Law, Criminology, and Police science 5 $(1914-1915): 851-879$.

McKelvey, Blake. "A Half Century of Southern Penal Exploitation." Social Forces 13 (October 1934): 112-123.

- "Penal Slavery and Southern Reconstruction." The Journal of Negro History 20 (April 1935): 153-179.

MCKnight, A. H. "Report of Commissioners to Revise Laws of Texas Appointed Under Act of July 28, 1876." Texas Law Review 6 (February 1928): 165-182.

Mancini, Matthew J. "Race, Economics, and the Abandonment of Convict Leasing." Journal of Negro History 63 (Fal1 1978): 339-352. 
Martin, Roscoe C. "The Grange as a Political Factor in Texas." Southwestern Social Science Quarterly 6 (March 1926): 363-383.

- "The Greenback Party in Texas." Southwestern Historical Quarterly 30 (January 1927): 161-177.

Meyrick, A. S. "Convict Labor and the Labor Reformers." The Princeton Review 59 (March 1883): 196-212.

Miller, E. T. "The Historical Development of the Texas State Tax System." Southwestern Historical Quarterly 55 (July 1951): 1-29.

- The State Finances of Texas during the Civil War." The Quarterly of the Texas State Historical Association 54 (October 1910): 87-112.

- "The State Finances of Texas During the Reconstruction." The Quarterly of the Texas State Historical Association 14 (October 1910): 87-112

Moseley, J. A. R. "The Citizens White Primary of Marion County." Southwestern Historical Quarterly 69 (April 1946): 524-531.

Noordberg, Henri Gerard. "A Young Texan Goes to War. A Collection of Personal Letters by Captain Thomas Jewett Goree, C.S.A., Aide-de-Camp to General James Longstreet." Journal, Confederate Historical Society 7 (Winter 1969): 142-159.

Parrish, T. Michael. "A New Species of Slavery." Paper presented at the Fall meeting of the East Texas Historical Association, September 27, 1980, Nacogdoches, Texas.

Potts, Charles S. "The Convict Labor of Texas." The Annals of the American Academy of Political and Social Science (May 1903): 426-437.

"Prison Labor." The Annals of the American Academy of Political and Social Science 46 (March 1913).

Reed, S. G. "Iand Grants and Other Aids to Texas RailRoads." Southwestern Historical Quarterly 49 (April 1946): 5i8-523.

Reese, James V. "The Early History of Labor Organizations in Texas, 1838-1876." Southwestern Historical Quarteriy 72 (July 1968): 1-20. 
Rhoads, Edward J. M. "The Chinese in Texas." Southwestern Historical Quarterly 81 (July, 1977): 1 -36.

Richardson, Rupert N. "Edward M. House and the Governors." Southwestern Historical Quarterly 61 (July 1957):

"Sanity in Solving Prison Labor Problems." American Federationist 2 (September 1904): $774-777$.

Sellin, Thorsten. "A Brief Guide to Penological Literature." The Annals of the American Academy of Political and Social Science 157 (September 1931): 225-232.

Smallwood, James. "Perpetuation of Caste: Black Agricultural Workers in Reconstruction Texas." MidAmerica. An Historical Review 61, pp. 5-23.

"Smashing the Lease System in Arkansas." Survey 30 (April 12, 1912): 54 .

Smith, Ralph A. "The Grange Movement in Texas, 1873-1900." Southwestern Historical Quarterly 42 (April 1939): 297-315.

Taylor, A. Elizabeth. "The Woman Suffrage Movement in Texas." Journal of Southern History 17 (May 1951): $19 \overline{4-215 .}$

"The Texas Penitentiary and Governor Campbell." Farm and Ranch 28 (December 11, 1909): 8.

Ward, Herbert D. "Peonage in America." Cosmopolitan 39 (August 1905): 423-430.

White, H. "Commissioner Wright on Convict Labor." The vation 45 (August 4, 1887): 88-89.

Whitin, E. Stagg. "Trade Unions and Prison Labor." Case and Comment 19 (September 1912): 240-244.

Woodman, Harold D. "Sequel to Slavery: The New History Views the Postbellum South." The Journal of Southern History 43 (November 1977): 523-554.

Wooster, Ralph A. "An Analysis of the Membership of the Texas Secession Convention." Southwestern Historical Quarterly 62 (January 1959).

- "Wealthy Texans, 1860." Southwestern Historical Quarterly 71 (October 1967): 163-180. 
Wright, Carroll D. "Prison Labor." North American Review 164 (March 1897): 273-282.

Zimmerman, Jane. "The Penal Reform Movement in the South During the. Progressive Era, 1890-1917." The Journal of Southern History 17 (November 1951):

\section{Theses and Dissertations}

Anderson, Adrian Norris. "Albert Sidney Burleson: A Southern Politician in the Progressive Era." Ph.D. dissertation, Texas Tech University, 1967.

Bailey, Lelia. "The Life and Public Career of $0 . M$. Roberts, 1815-1883." Ph.D. dissertation, University of Texas, 1932 .

Barron, John Daniel. "A Critical History of the Texas Christian Advocate, 1849-1949." M.A. thesis, University of Missouri, Columbia, 1952.

Bayliss, Garland E. "Public Affairs in Arkansas, 18741896." Ph.D. dissertation, University of Texas at Austin, 1972 .

Birmingham, Billy Martin. "An Historical Account of the East Texas Prison at Rusk." The Institute of Contemporary Corrections and the Behavioral Sciences, Sam Houston State University, 1979.

Blatner, William E. "Some Aspects of the Convict Lease System in the Southern States." M.A. thesis, University of Oklahoma, 1952.

Bowles, Willie D. "The History of the Woman Suffrage vovement in Texas." M.A. thesis, University of Texas, 1939.

Brooks, Glynn Austin. "A Political Survey of the Prohibition Movement in Texas." M.A. thesis, University of Texas, 1920.

Erown, Katherine. "A Social History of Texas Baptists since 1865." M.A. thesis, Baylor University, 1949 .

zrown, Patrick. "A Study of the Laws Passed During the Administration of $O$. M. Roberzs, Governor oz Texas, 1879-1883." M.A. thesis, Sam Houston State Teachers College, 1949. 
Budd, Harrell. "The Negro in Politics in Texas, 18671898." M.A. thesis, University of Texas, 1925.

Buzbee, Thomas M. "A Historical Overview of the American Labor Movement and It's Influence on Corrections." M.A. thesis, The Institute of Contemporary Corrections and the Behavioral Sciences, Sam Houston State University, 1975.

Carper, Noel Gordon. "The Convict-Lease System in Florida, 1866-1923." Ph.D. dissertation, The Florida State University, 1964 .

Carter, Dan T. "Prisons, Politics and Business: The Convict Lease System in Post-Civil War South." M.A. thesis, University of Wisconsin, 1964 .

Cathey, Velma Lee. "History of Public Welfare Legislation in Texas." M.A. thesis, North Texas State College, 1949 .

Crow, Herman Lee. "A Political History of the Texas Penal System, 1829-1951." Ph.D. dissertation, University of Texas, 1964.

Farrow, Marion Humphreys. "The Rise of the Democrats to Power in Texas, 1872-1876." M.A. thesis, University of Texas, 1940 .

Ford, Hiram U. "A History of the Arkansas Penitentiary to 1900." M.A. thesis, University of Arkansas, 1936 .

Gildemeister, Glen Albert. "Prison Labor and Convict Competition with Free Workers in Industrializing America, 1840-1890." Ph.D. dissertation, Northern Illinois University, 1977.

Gilmore, Harry William. "The Convict Lease System in Arkansas." M.A. thesis, George Peabody College for Teachers, 1930 .

Grant, Truett King. "The Negro Exodus, 1879-1880." M.A. thesis, Baylor University, 1952.

Hallman, Jacqueline Rankin. "A Calendar of the Memorials and Petitions to the Legislature of Texas from 1877 to 1937." M.A. thesis, University of Texas, 1938. 
Huckaby, George Portal. "Oscar Branch Colquitt: A $+400$ Political Biography." Ph.D. dissertation, University of Texas, 1946.

Kinsey, Winston Lee. "Negro Labor in Texas, 1865-1876." M.A. thesis, Baylor University, 1965.

Lowry, Wallace Edwin. "A Survey of Education in the Texas Prison System." M.A. thesis, University of Texas, 1935 .

Mickay, Seth Shepard. "Texas Under the Regime of E. J. Davis." M.A. thesis, University of Texas, 1919.

Maroney, James C. "Organized Labor in Texas, 1900-1929." Ph.D. dissertation, University of Houston, 1975.

Martin, Ruby Lee. "The Administration of Governor S. W. T. Lanham, 1903-1907." N.A. thesis, University of Texas, 1937.

Mason, George Truett. "A Study of the Iron Industries of Cherokee County." M.A. thesis, University of Texas, 1938 .

Moore, Sue E. Winton. "Thomas B. Love, Texas Democrat, 1901-1949." M.A. thesis, University of Texas at Austin, 1971.

Mullenix, Grady Lee. "A History of the Texas State Federation of Labor." Ph.D. dissertation, University of Texas, 1955 .

Nielsen, George Raymond. "Richard Bennett Hubbard, 'The Demosthenes of Texas.'" M.A. thesis, University of Houston, 1957 .

Norton, Frank Edgar. "The Major Administrative Policies of Oran M. Roberts, with an Introduction to his Iife." M.A. thesis, University of Texas, 1925.

Nowlin, James Robertson. "A Political History of the Texas Prison System, 1849-1957." M.A. thesis, Trinity University, San Antonio, 1962.

Parrish, Thomas Michael. "This Species of Slave Labor: The Convict Lease System in Texas, 1871-1914." M.A. thesis, Baylor University, 1976.

Reese, James Verdo. "The Worker in Texas, 1821-1876." Ph.D. dissertation, University of Texas, 1964. 
Reynolds, James Robert. "The Administration of the Texas Prison System." M.A. thesis, University of Texas,
1925.

Richter, William L. "The Army in Texas during Reconstruction, 1865-1870." Ph.D. dissertation, Louisiana State University, 1970.

Sandin, Betty Jeffers. "The Texas Reconstruction Constitutional Convention of 1868-1869." Ph.D. dissertation, Texas Tech University, 1970.

Schmelzer, Janet Louise. "Thomas Mitchell Campbell: Progressive Governor of Texas." M.A. thesis, Texas Christian University, 1975.

Shook, Robert W. "Federal Occupation and Administration of Texas, 1865-1870." Ph.D. dissertation, North Texas State University, 1970.

Smith, Maggie Ruhamah. "The Administration of Governor John Ireland, 1883-1887." M.A. thesis, University of Texas, 1934.

Stout, Leon. "Origin and Early History of the Louisiana Penitentiary." M.A. thesis, Louisiana State University, 1934.

Sullenberger, Thomas E. "An Interpretive History of the Texas Convict Lease System, 1871-1914." M.A. thesis. The Institute of Contemporary Corrections and the Behavioral Sciences, Sam Houston State University, 1974.

Tatum, Bowen C. "The Penitentiary Movement in Texas, 18471849." M.A. thesis, Institute of Contemporary Corrections and Behavioral Sciences, Sam Houston State University, 1970.

Tenney, James Leighton. "The Public Services of Joseph Draper Sayers." M.A. thesis, University of Texas, 1933.

Tinsley, James Aubrey. "The Progressive Movement in Texas." Ph.D. dissertation, University of Wisconsin, 1953.

Wagner, Robert Lancaster. "The Gubernatorial Career of Charles Allen Culberson." M.A. thesis, University of Texas, 1954. 
Webb, Juanita Oliver. "The Administration of Governor L. S. Ross, 1887-1891." M.A. thesis, University of Texas, 1935.

Younker, Donna Lee. "Thomas B. Love's Service in the Texas Legislature and in State Government during the Lanham and Campbell Administrations." M.A. thesis, Southern Methodist University, 1958.

Zimmerman, Hilda Jane. "Penal Systems and Penal Reforms in the South since the Civil War." Ph.D. dissertation, University of North Carolina, Chapel Hill, 1947 . 